\title{
Kreatywność \\ w systemie edukacji
}

- SERIA NAUKOWA

Redakcja naukowa

Jan Fazlagić

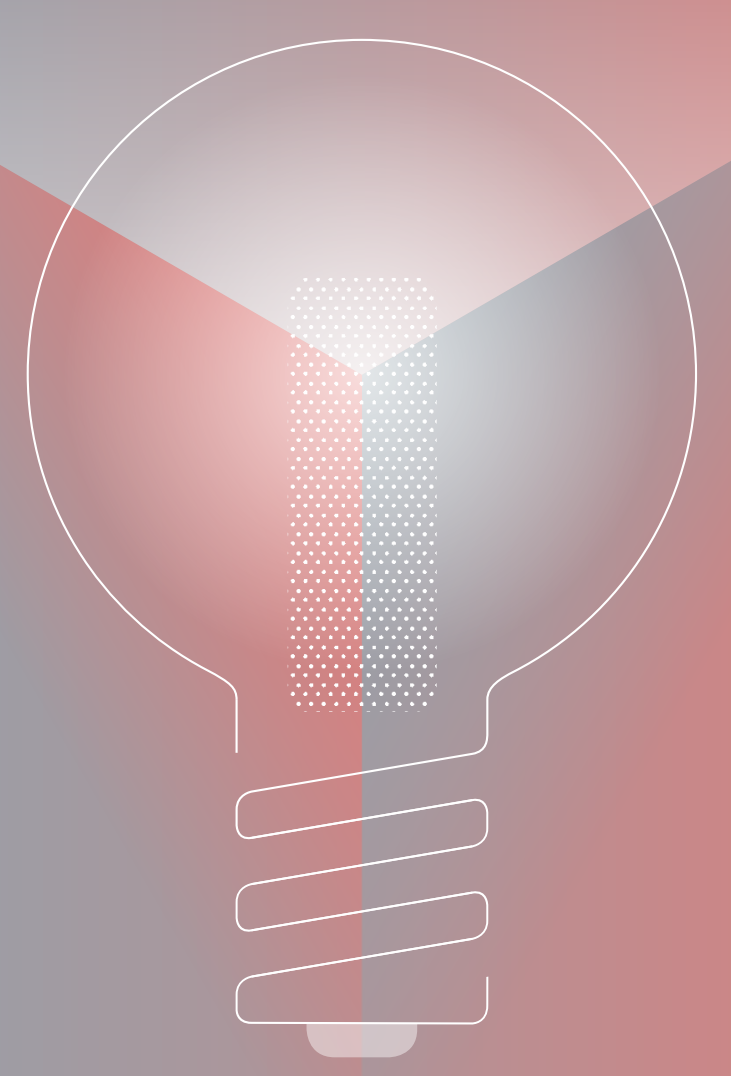


Kreatywność w systemie edukacji 



\section{Kreatywność w systemie edukacji}

Redakcja naukowa

Jan Fazlagić 


\section{SERIA NAUKOWA, TOM 8}

\section{Kreatywność w systemie edukacji}

Redaktor naukowy: prof. dr hab. Jan Fazlagić

Współpraca: Agnieszka Rybińska

Recenzent: $\quad$ prof. dr hab. Bazyli Poskrobko

Redaktorzy prowadzący: Barbara Jędraszko, Radosław Krąpiec

Korekta: $\quad$ Editio Beata Bociąg (editio.eu), Kropki Kreski Monika Buraczyńska (kropki-kreski.pl)

Projekt graficzny: Diana Makulska/Podpunkt

Projekt okładki i skład: Mariusz Skarbek

Druk:

Multigraf Drukarnia Sp. z o.o. Bydgoszcz

Wydawca: $\quad$ Fundacja Rozwoju Systemu Edukacji

Narodowa Agencja Programu Erasmus+

Al. Jerozolimskie 142a, 02-305 Warszawa

www.frse.org.pl | kontakt@frse.org.pl

(c) Fundacja Rozwoju Systemu Edukacji, Warszawa 2019

ISBN: 978-83-65591-87-6

Publikacja została wydana przy wsparciu finansowym Komisji Europejskiej w ramach programu Erasmus+. Publikacja odzwierciedla jedynie stanowisko jej autorów i Komisja Europejska nie ponosi odpowiedzialności za zamieszczoną w niej zawartość merytoryczną.

Publikacja bezpłatna

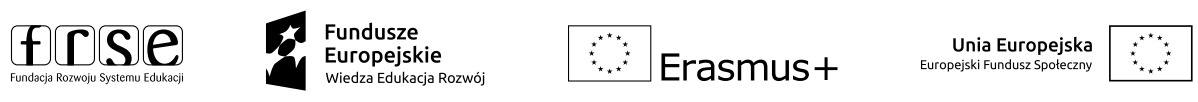

Cytowanie:

Kreatywność w systemie edukacji, red. nauk. Jan Fazlagić, Fundacja Rozwoju Systemu Edukacji, Seria Naukowa, t. 8, Warszawa 2019.

Publikacje Wydawnictwa FRSE są dostępne na stronie czytelnia.frse.org.pl 


\section{Spis treści}

9

Wstęp

13

Wprowadzenie

Jan Fazlagić

\section{Kreatywni ludzie}

22

Wszyscy jesteśmy kreatywni: wymogi wstępne i elementy procesu twórczego

Agnieszka Szóstek

32

Czy wszyscy muszą być kreatywni?

Aldona Andrzejczak

52

Kreatywność osób dojrzałych i czynniki sprzyjające

jej wzbudzaniu

Grażyna Bartkowiak 


\section{Rola kreatywności w systemach edukacji}

66

Przygotowanie i ocenianie zadań kształcących kreatywność i myślenie projektowe uczniów

Adam Kalbarczyk

80

Rozwój kompetencji proinnowacyjnych u uczniów - przykład niemieckich szkół podstawowych i ponadpodstawowych Piotr Trapczyński

100

Kompetencje miękkie w międzynarodowym kształceniu zawodowym na przykładzie szkolenia EDTECH

Monika Tomczyk

\section{Wsparcie kreatywności w szkole}

118

Jak zaprojektować kreatywną lekcję?

Marlena Plebańska

134

Ocena kreatywności uczniów - wyzwanie dla systemu edukacji Jan Fazlagić

160

Sam trening kreatywności nie wystarczy... Uwagi o wspieraniu kreatywności w szkole

Anna Klimowicz 
Kreatywność na rynku pracy

176

Znaczenie i sposoby rozwoju kreatywności

w gospodarce cyfrowej

Dorota Roszkowska

188

Kreatywność w rozwiązywaniu problemów biznesowych

Sergiusz Sawin

200

Zapotrzebowanie na kompetencje w przemysłach kreatywnych Bogumita Powichrowska

Wywiady z przedsiębiorcami i ekspertami

213

Rozmowy przeprowadzone przez prof. dr hab. Jana Fazlagicia 



\section{Wstęp}

Książka, którą oddajemy w ręce Czytelnika, ma na celu przybliżenie tematyki kreatywności z perspektywy polskiego systemu edukacji. Rosnące znaczenie kreatywności w naszej rzeczywistości, także w systemach edukacji, wynika z pojawiania się nowych aspektów otoczenia społeczno-gospodarczego, wśród których warto wymienić:

$\rightarrow$ Rozwój sztucznej inteligencji i wynikającą z niego polaryzację w zapotrzebowaniu na nowych pracowników. Pracownicy o średnich kompetencjach będą w niedalekiej przyszłości mniej niż obecnie poszukiwani przez pracodawców. Wzrośnie natomiast popyt na słabo wykształconych pracowników oraz pracowników o wysokich kompetencjach, na które będą składały się przede wszystkim kreatywność i zdolność do krytycznego myślenia.

$\rightarrow$ Rosnącą konkurencję międzynarodową opierającą się nie na dominacji nad terytorium, jak było w przeszłości, lecz na dominacji w obszarze tworzenia nowej wiedzy i innowacji. Europa potrzebuje więcej przedsiębiorczości i więcej innowacji. Wynika to $z$ faktu, że koszty pracy w Europie są znacznie wyższe niż w większości krajów na innych kontynentach. $Z$ drugiej strony znacznie niższe tempo wzrostu gospodarczego w Europie sprawia, że rządom europejskim coraz trudniej zaspokajać rosnące potrzeby społeczne i państwowe.

$\rightarrow$ Rosnące w ramach tej międzynarodowej konkurencji na polu ekonomicznym przekonanie w wielu państwach na świecie, że to efektywne systemy edukacji są kluczem do uzyskania międzynarodowej przewagi konkurencyjnej.

$\rightarrow$ Zmieniające się oczekiwania wobec szkoły, także ze strony uczniów, rodziców i pracodawców, zmiany kulturowe i społecz- 
ne oraz wprowadzane do szkół nowe technologie, wymagające przemodelowania systemów nauczania. W tym kontekście najbardziej istotna wydaje się potrzeba położenia większego nacisku na rozwój kreatywności u uczniów.

$\rightarrow$ Zmiany klimatyczne wymagające poszerzenia programów nauczania o tematykę ekologiczną. Należy również połączyć rozwój kreatywności z rozwojem postaw proekologicznych. Innowacyjna gospodarka będzie potrzebować coraz więcej innowacji klimatycznych.

Niniejsza publikacja dzieli się na pięć części tematycznych:

$\rightarrow$ Kreatywni ludzie,

$\rightarrow$ Rola kreatywności w systemach edukacji,

$\rightarrow$ Wsparcie kreatywności w szkole,

$\rightarrow$ Kreatywność na rynku pracy,

$\rightarrow$ Wywiady z przedsiębiorcami i ekspertami.

Składa się na nie 12 rozdziałów napisanych przez ekspertów znających tematykę kreatywności ze swojej pracy naukowej i praktyki w biznesie oraz 10 wypowiedzi specjalistów.

W pierwszej części opisano kreatywność widzianą z perspektywy jednostki. Książkę otwierają dwa rozdziały odnoszące się do fundamentalnych zagadnień $w$ tym zakresie: kreatywności jako cechy powszechnej u wszystkich ludzi oraz kreatywności jako cechy oczekiwanej (ale czy słusznie?) od wszystkich ludzi. Część pierwszą kończy rozdział dotyczący mitu, który głosi, że kreatywność jest cechą zarezerwowaną dla osób młodych.

W drugiej części problematykę kreatywności przedstawiono z perspektywy systemów edukacji. Jest to niezwykle ważne, ponieważ największe wyzwanie dla pedagogów stanowi nie opracowanie innowacyjnych programów nauczania i scenariuszy lekcji, a zapewnienie, aby były one realizowane na masową skalę, w sposób spójny w całym systemie edukacji.

W trzeciej części książki przeanalizowano kreatywność z poziomu zarządzania pojedynczą szkołą. Dyrektorzy placówek znajdą tutaj odpowiedzi na pytanie, jak organizować życie szkoły, aby była ona bardziej przyjazna dla uczniów kreatywnych. 
Kolejną część publikacji poświęcono kreatywności z perspektywy ekonomicznej. Celem autorów było podkreślenie ścisłych związków między edukacją dla kreatywności a potrzebami rynku pracy oraz rozwoju gospodarczego i nowych modeli biznesowych.

W ostatniej części przedstawiono opinie ekspertów i przedsiębiorców na temat polskiej szkoły i edukacji w kontekście rozwoju kreatywności. Są one wynikiem rozmów, podczas których eksperci i przedsiębiorcy zostali zapytani m.in. o to: czy ich zdaniem nauczanie kreatywności powinno być zadaniem szkoły / systemu edukacji, czy też szkoły powinny koncentrować się na przekazywaniu wiedzy, a także czy obserwują deficyt kreatywności wśród pracowników zatrudnionych w firmach, którymi zarządzają? 



\section{Wprowadzenie}

Rozwój kreatywności u uczniów powinien być centralnym zagadnieniem w systemach edukacji (OECD 2016), a kreatywność i innowacje stanowią podstawę polityki edukacyjnej Unii Europejskiej (Ferrari i in. 2009; European Union 2010; Coate, Boulos 2012; Griffiths 2014). Motyw przewodni tej książki - kreatywność - powszechnie kojarzy się z różnorodnością, oryginalnością, wyobraźnią, wychodzeniem poza schematy, postrzeganiem rzeczywistości z wielu perspektyw. Przed przystąpieniem do lektury warto jednak usystematyzować główne pojęcia związane z kreatywnością, a także przedstawić ją w kontekście systemu edukacji jako całości.

\section{Czym jest kreatywność?}

Słowo "kreatywność" może być rozumiane wieloznacznie. Przykładowo niektórzy będą twierdzić, że jej synonimem w języku polskim jest „twórczość". Inni będą skłonni uważać, że „twórczość" odnosi się do tworzenia dzieł. Z drugiej strony wykorzystanie modelu $5 \mathrm{P}$ w celu lepszego zrozumienia pojęcia kreatywności pokazuje, że dzieło twórcze, czyli "produkt", jest jednym z wzajemnie uzupełniających się komponentów. Model 5P służy holistycznemu zdefiniowaniu kreatywności jako cechy pięciu obiektów, które dopiero łącznie pozwalają opisać istotę kreatywności':

$\rightarrow$ Person-osoba,

$\rightarrow$ Product - wynik procesu kreatywnego,

$\rightarrow$ Process-proces,

$\rightarrow$ Press-środowisko,

$\rightarrow$ Passion - pasja. 
O ile innowacyjność dotyczy efektów pracy, które mają przełożenie na poprawę jakości życia, zwiększenie efektywności jakiegoś procesu lub urządzenia (i dlatego innowacyjność kojarzy się z naukami ekonomicznymi i zarządzaniem), o tyle kreatywność jest cechą pojedynczego człowieka, a jej badaniem zajmuje się psychologia (psychologia twórczości). Kreatywność (twórczość) to proces prowadzący do powstania nowego wytworu, który jest akceptowany jako użyteczny i do przyjęcia dla pewnej grupy w pewnym okresie (Nęcka 2003). Twórczość to cecha każdego człowieka. Dana osoba może się nią cechować w różnym stopniu. Może więc być kreatywna minimalnie bądź też wybitnie czy unikatowo. Twórczość stanowi swego rodzaju przeciwieństwo naśladownictwa. Rozróżniamy dwa rodzaje twórczości (oba są ważne). Pierwszy to tzw. twórczość przez duże "T", odnosząca się do działalności osób wybitnych: pisarzy, malarzy, reżyserów itd. W życiu codziennym ważna jest także twórczość pisana przez małe „t". Ważne, abyśmy nie utożsamiali kształtowania kreatywnych umysłów z ambitnymi celami, takimi jak np. wykształcenie kolejnej Marii Skłodowskiej-Curie. Dla budowy innowacyjnego społeczeństwa prawdopodobnie ważniejsze jest, abyśmy wychowali wielu "twórców" niż niewielu "Twórców".

Bycie osobą kreatywną oznacza widzenie tej samej rzeczy jak wszyscy inni, lecz myślenie o niej w inny sposób. Kreatywność to cecha pozwalająca tworzyć i rozpoznawać nowe pomysły, alternatywy i możliwości, które mogą być pomocne w rozwiązywaniu problemów, komunikowaniu się z innymi ludźmi lub dostarczaniu rozrywki sobie lub innym. Oscar Wilde powiedział, że ludzie rozsądni próbują dostosować się do otaczającego ich świata, a ludzie nierozsądni próbują go zmienić. W związku z tym cały postęp zawdzięczamy ludziom nierozsądnym. Ludzie uznawani za twórczych dostrzegli coś, czego inni nie widzieli. Osoby mało twórcze uznają porządek zastany za naturalny, a zmianę traktują jako zamach na niego.

Jak określić, czy dana jednostka jest twórcza? Istnieje na to dość prosty sposób. Należy ocenić proces i wyniki realizacji zadania, które wymaga zastosowania umiejętności twórczych. Najlepiej, aby zadanie, które chcemy wykorzystać do testu, miało jakiś wymiar praktyczny. Przykładem zadania pozbawionego wymiaru praktycznego (lecz często stosowanego) jest pytanie: „Co by się stało, gdyby ludzie mieli sześć palców u każdej z rąk?". Lepiej osoby testowane prosić o rozwiązanie zadania dotyczącego realnego problemu z ich życia, np.: „Przedstaw 
rozwiązania organizacyjne, które wprowadziłbyś w swojej gminie, gdyby budżet na oświatę zwiększono o 100 proc.". Następnie należy ocenić kreatywność danej osoby za pomocą czterech kryteriów:

$\rightarrow$ Płynności, czyli łatwości wytwarzania pomysłów - ich liczby. Im więcej pomysłów dana osoba wytworzy w danym czasie, tym lepszą ma płynność. Wyróżniamy trzy rodzaje płynności:

- słowną, np. podanie jak największej liczby słów zaczynających się na literę "L";

- ideacyjną, np. wytworzenie jak największej liczby rozwiązań problemów;

- skojarzeniową, np. podanie jak największej liczby słów kojarzących się z wyrazem "owca".

$\rightarrow$ Giętkości, czyli gotowości do zmiany kierunku myślenia. Operacyjnym wskaźnikiem tej zdolności może być różnorodność pomysłów, czyli liczba kategorii, do jakich można je zaliczyć. Istnieją dwa rodzaje giętkości:

- spontaniczna - polegająca na niewymuszonej zmianie kierunku myślenia;

- adaptacyjna - związana z modyfikacją procesu myślenia pod wpływem konieczności dostosowania się do okoliczności lub warunków zadania.

$\rightarrow$ Oryginalności, czyli zdolności do wytwarzania reakcji nietypowych, niezwykłych, niepowtarzalnych. Najprostszym kryterium oryginalności jest zbadanie, u ilu testowanych osób pojawiło się dane rozwiązanie.

$\rightarrow$ Staranności, czyli ilości pracy włożonej w ekspresję pomysłu, np. liczba słów poświęconych na jego opis lub liczba szczegółów wykorzystywanych w opisie.

Kreatywność staje się głównym elementem treści i metod nauczania (Wilson 2005) oraz "oficjalną agendą" dla reform edukacji (Burnard 2006). W niektórych krajach ambitne manifesty dotyczące położenia większego nacisku na nauczanie kreatywności są już wdrażane, m.in. w Hongkongu, Chinach, Japonii i Szkocji. Zdaniem Teresy Amabile (1983) kreatywność to zdolność do tworzenia pomysłów i idei lub też nowych sposobów rozwiązywania problemów czy spoglądania na szanse $w$ otoczeniu lub wśród własnych zasobów osobistych. Innowacja to zdolność do wdrażania kreatywnych pomysłów w celu rozwiązania 
tych problemów lub wykorzystania nowych możliwości (Kabukcu 2015). Kreatywność mocniej wiąże się z myśleniem, a innowacja - z robieniem. Jest to jednak definicja zbyt upraszczająca, ponieważ osoby kreatywne także robią nowe rzeczy, tworzą np. obrazy, rzeźby, schematy, techniki wykonywania, projekty, koncepcje, idee. W 1988 r. Teresa Amabile opracowała model koncepcyjny, który wyjaśniał relacje między kreatywnością i innowacją. Swoją koncepcję rozwinęła w 1997 r., uznając, że kreatywność zasila innowację, natomiast środowisko wpływa na kreatywność (Amabile 1997). Kreatywność stanowi wynik połączenia motywacji, kompetencji kreatywnych i wiedzy w danej dziedzinie (schemat 1).

Schemat 1. Elementy procesu innowacji

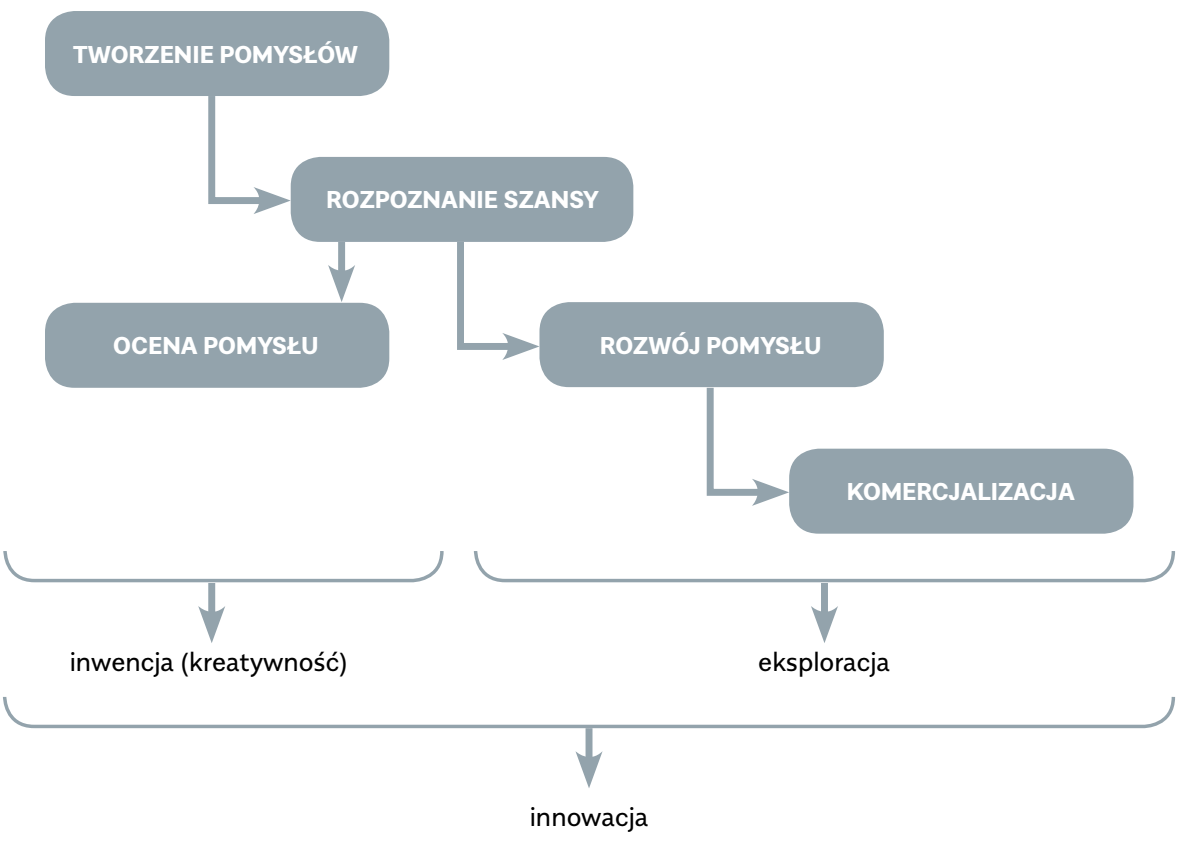

Źródło: Luecke, Katz 2003.

Kreatywność przybiera formę dziedzinową (domain-specific). Oznacza to, że większość ludzi, z małymi wyjątkami, jak np. Leonardo da Vinci, jest kreatywna w pewnych dziedzinach. Podobnie jest z przed- 
siębiorczością: wyróżniamy przedsiębiorczość społeczną, naukową, ekonomiczną, intelektualną itp. Z kolei innowacyjność służy polepszaniu jakości życia ludzi za sprawą idei, produktów, wytworów, usług itd.

\section{Człowiek kreatywny}

Osobę kreatywną można zdefiniować na podstawie zarówno pewnych cech osobowych, jak i opisu zachowań i działań osób kreatywnych, które odróżniają je od ludzi mniej kreatywnych. Tutaj warto także podkreślić, że kreatywność nie jest cechą dychotomiczną: każdy człowiek w mniejszym lub większym stopniu odznacza się kreatywnością. Ponadto kreatywność człowieka nie jest cechą stałą w czasie. W zależności od nastroju, poziomu stresu, motywacji i środowiska ta sama osoba może wykazywać bardzo zróżnicowane wyniki kreatywności. Osoby kreatywne są zwykle twórcze w jakiejś dziedzinie lub wiązce dziedzin. Natomiast rzadko zdarza się, aby osoba była kreatywna w bardzo szerokim zakresie dziedzin, tak jak np. wspomniany już Leonardo da Vinci, Richard Feynman, znany fizyk i noblista, a jednocześnie doskonały pisarz, czy też polski muzyk i wynalazca Józef Hofmann². Kreatywność jest coraz częściej przeciwstawiana inteligencji nie tylko jako cecha odrębna, ale także jako cecha, która przy pewnym poziomie inteligencji danej osoby przestaje z nią korelować (hipoteza progu). Osoby przeciętnie i mało inteligentne będą wówczas także mało lub przeciętnie kreatywne. Natomiast wśród osób o wybitnej inteligencji będzie można spotkać osoby zarówno bardzo kreatywne, jak i przeciętnie kreatywne. Współczesne normy społeczne raczej faworyzują wybitnie inteligentnych obdarzonych przeciętną kreatywnością niż na odwrót: wybitnie kreatywnych o przeciętnej inteligencji. Wizerunek osoby wybitnie inteligentnej budzi pozytywne konotacje, które są wzmacniane przez proces edukacji w szkole. Jedną ze zmian, jakie można wprowadzić w systemie edukacji w XXI w., mogłoby więc być uznanie uczniów kreatywnych podobizna Józefa Hofmanna. Hofmann to także wybitny wynalazca. To jemu przypisuje się stworzenie m.in. spinacza biurowego, zegara elektrycznego, grzałki do wody czy pieca na ropę naftową. Zaprojektował też pneumatyczne amortyzatory samochodowe, zderzaki sprężynowe i coś, bez czego nie istnieje żadne auto - wycieraczki samochodowe. Stworzył również podwaliny pod współczesne systemy nawigacyjne (Domaradzki 2018). 
w życiu szkolnym za wzór dla społeczności szkolnej. Edward de Bono, światowy ekspert w dziedzinie umiejętności kreatywnego myślenia, twierdzi, że aby móc w pełni wykorzystać umiejętności kreatywnego myślenia, trzeba stać się tzw. człowiekiem myślącym. Według niego człowiek myślący:

$\rightarrow$ ma zaufanie do własnej umiejętności myślenia;

$\rightarrow$ potrafi świadomie zabrać się do myślenia i skupić na konkretnej sprawie;

$\rightarrow$ zawsze potrafi zdefiniować cel swojego namysłu i określić, w jaki sposób zamierza go osiągnąć;

$\rightarrow$ zdaje sobie sprawę z tego, że jakiekolwiek podejście do określonej sprawy czy sposób widzenia sytuacji jest tylko jednym z licznych możliwych podejść czy sposobów, z których większość nie przyszła mu do głowy;

$\rightarrow$ potrafi docenić to, co osiągnął, nawet jeżeli jest to tylko świadomość, że problem wymaga dalszego namysłu;

$\rightarrow$ uważa, że myślenie jest sztuką, w której warto się doskonalić i której trzeba się przyglądać;

$\rightarrow$ uważa, że myśli się po to, żeby lepiej zrozumieć rzeczywistość, żeby podejmować trafne decyzje i żeby wypracowywać lepsze sposoby postępowania, a nie po to, żeby udowodnić, że jest się mądrzejszym od innych. 



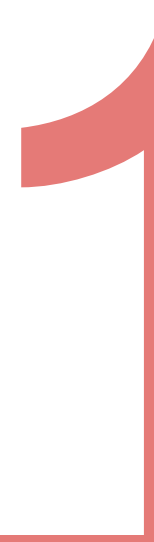

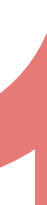




\section{Kreatywni ludzie}




\title{
Wszyscy jesteśmy kreatywni: \\ wymogi wstępne i elementy procesu \\ twórczego
}

\author{
Agnieszka Szóstek
}

Czy uważasz się za osobę kreatywną? Czy kreatywność to cecha wrodzona, czy też umiejętność, którą można regularnie rozwijać? Czy to prawda, że każdy jest kreatywny? W tym rozdziale przedstawiono definicję kreatywności i podstawowe elementy procesu twórczego. Opisano także pokrótce trzy różne podejścia twórcze do rozwiązywania problemów, aby pokazać, że nie ma jednego uniwersalnego sposobu na bycie kreatywnym. Na koniec omówiono znaczenie refleksyjnej praktyki, treningu kreatywnego i oceny kreatywności na podstawie oceny postępów, a nie wyników, jako sposobu na zachowanie kreatywności przez całe życie.

\section{__ Słowa kluczowe: \\ definicja kreatywności \\ proces kreatywny \\ podejście kreatywne \\ nastawienie na rozwój \\ praktyka refleksyjna \\ trening kreatywny \\ ocena kreatywności}




\title{
We are all creative: \\ the prerequisites and ingredients of the creative process
}

\author{
Agnieszka Szóstek
}

Do you consider yourself creative? Is creativity an in-born quality or a practice that can be developed over time? Is it true that everyone is creative? This chapter looks into the definition of creativity and the core ingredients of the creative process. It further shortly describes three different creative approaches to solving problems to show that there is no one universal way of being creative. Finally, it discusses the importance of reflective practice, creative training and creativity assessment based on evaluating the progress and not the outcome as a way to stay creative throughout life. 


\section{Czym jest kreatywność?}

Czy kreatywność jest wrodzonym talentem, czy raczej jest to kwestia praktyki, jak np. jazda na rowerze? Czy kreatywność wiąże się z kilkoma zawodami lub czy ktoś może być kreatywny, bez względu na to, co robi w ramach swoich obowiązków służbowych? Czy ktoś może zapomnieć, jak to jest być kreatywnym? Czy są niekreatywne dzieci? Czy to takie dzieci, które nie ćwiczą swojej wyobraźni i nie są motywowane do tworzenia własnych wynalazków (nawet jeśli jest to tylko zamek z piasku)? Co przydarzyło się dorosłym, którzy w pewnym momencie stwierdzają, że nie są już kreatywni? Zacznijmy od definicji kreatywności, aby móc zgłębić to zagadnienie.

Co ciekawe, wydaje się, że nie ma powszechnej zgody co do definicji kreatywności. Na szczęście ostatnio osiągnięto pewne porozumienie (Daly, Mosyjowski, Seifert 2014). Większość badaczy w dziedzinie kreatywności zdaje się skupiać na dwóch podstawowych aspektach, które decydują o tym, czy proces kreatywny miał miejsce, czy też nie: wynik przedsięwzięcia twórczego musi wnosić coś nowego lub odmiennego, a proponowany rezultat musi odpowiadać problemowi, który miał być rozwiązany w pierwszej kolejności (Barron 1955; Guilford 1967; Stein 1953). Z definicji tych można wywnioskować, że kreatywność jest grą multiplikatywną, a jej rezultat to wszystko albo nic: albo masz efekt twórczy, albo nie (Simonton 1996). Jednak definicje te koncentrują się tylko na wyniku lub rezultacie procesu twórczego. Natomiast zdaniem wielu innych naukowców kreatywność nie jest cechą dychotomiczną - występuje w różnym nasileniu u różnych ludzi (patrz m.in. Csíkszentmihályi 1996).

Trzeci element kreatywności, czyli jakość, został ostatnio włączony do tego równania (Sternberg, Kaufman, Pretz 2013). Rezultatem procesu twórczego powinno być nie tylko znalezienie nowego rozwiązania danego problemu. Te nowe rozwiązania powinny również być wartościowe.

Wszystkie te elementy kreatywności odnoszą się do rezultatu procesu twórczego. Ale co z samym procesem? Przykładowo David Perkins (2001) mówi o nieplanowanym i nieustrukturyzowanym charakterze procesu twórczego, którego punktem zwrotnym są momenty "aha". W proces ten musi być wpisany element zaskoczenia, odkrycia czegoś nieznanego (Simonton 2010). Ale obejmuje on jeszcze coś. Ken Robinson i Lou Aronika (2009) wskazują, że proces twórczy jest dynamicz- 
ny: wymaga działania, a nie tylko myślenia. Stanowi podróż krętymi ścieżkami, w trakcie której można błądzić i trafić w ślepe zaułki i której cel pozostaje niepewny. Nie sprowadza się do wpadnięcia na pierwszy pomysł, który od razu jest najlepszy (jak wielu wydaje się myśleć), ale raczej polega na analizie tego pomysłu i rozwinięciu go w coś, co zaskoczy nawet samego twórcę.

Ostatni element kreatywności odnosi się do współpracy. Ze względu na aspekty historyczne wielu ludzi wyobraża sobie twórcę jako samotnego geniusza, który wpada na w pełni ukształtowany pomysł. To wrażenie nie może być bardziej odległe od dzisiejszej rzeczywistości. Poza kilkoma wyjątkami, proces twórczy stanowi obecnie wspólne przedsięwzięcie. Czerpie on z różnych umiejętności i wiedzy, z różnych perspektyw i światopoglądów. Najbardziej kreatywne rezultaty dzisiejszych czasów rodzą się na styku różnych dziedzin i dyscyplin, a często także kultur (Bennis, Biederman 2007). Mit jednostki twórczej należy umieścić tam, gdzie jego miejsce: obok innych historii z przeszłości.

\section{Proces twórczy}

Jak wspomniano, kreatywność jest w zasadzie procesem. I proces ten (choć dość elastyczny z natury) wymaga podjęcia kilku niezbędnych kroków. Przede wszystkim nieodzowny jest etap tworzenia nowych pomysłów, przewidywania różnych możliwości i rozważania alternatywnych opcji (Buxton 2010). Aby jednak dojść do tego etapu, należy określić kontekst dla innowacji, niezależnie od tego, czy chodzi o dostrzeżenie rzeczywistego problemu, określenie wyzwania artystycznego, czy też postawienie pytania naukowego. Innymi słowy, proces twórczy wymaga dobrze zdefiniowanego celu (Sternberg 2006). Wymaga też eksperymentowania: badania pomysłów w środowisku naturalnym i sprawdzania ich z innymi, aby przekonać się, które z nich się przyjmą, a które powinny zostać zarzucone. Wszystkie te kroki nie muszą być realizowane w uprzednio określonej kolejności. One wzajemnie na siebie oddziałują, tworząc "delikatną równowagę między opracowywaniem pomysłów a ich odrzucaniem i udoskonalaniem" (Robinson, Aronika 2009).

Jeden z pierwszych modeli procesu twórczego zaproponowany przez Wallasa w 1926 r. opierał się na koncepcjach fizyka Hermanna von Helmholtza. W modelu tym zaproponowano pięć etapów kreatywnego rozwiązywania problemów: 
$\rightarrow$ przygotowanie lub definiowanie problemu,

$\rightarrow$ inkubacja lub czas, w jakim mózg rozważa dany problem,

$\rightarrow$ przeczuwanie lub uświadomienie sobie, że nastąpi przełom,

$\rightarrow$ oświecenie lub moment głębokiego zrozumienia,

$\rightarrow$ weryfikacja, rozwijanie i testowanie pomysłu.

Definiowanie problemu (inaczej określane formułowaniem problemu) jest czasami podważane lub pomijane, mimo niezliczonych przypadków, w których okazuje się kluczowe dla jakości rezultatów procesu twórczego (Reiter-Palmon, Robinson 2009). Na tym etapie dochodzimy do tego, na czym dokładnie polega problem, który próbujemy rozwiązać, i jakie ograniczenia są z nim związane. Wiele osób zakłada, że ten etap jest automatyczny: wiemy, w czym tkwi problem. Jednak udowodniono, że osoby odnoszące sukcesy kreatywne aktywnie angażują się na tym etapie i poświęcają mu znaczną ilość czasu (Csíkszentmihályi, Getzels 1971). Należy tu stwierdzić, że badania wykazują, iż umiejętność formułowania problemu prowadzi do większej oryginalności i wyższej jakości kolejnego rozwiązania (Runco 1994; Reiter-Palmon, Robinson 2009).

Opracowywanie pomysłów często postrzega się jako podstawę kreatywności. Można je inaczej nazwać myśleniem dywergencyjnym lub umiejętnością przedstawiania różnych pomysłów w celu rozwiązania danego problemu (Guilford 1967). Koncepcja ta stanowi podwaliny pomiaru kreatywności już od ponad wieku. Ale ma ona ciemną stronę: wielość pomysłów nie oznacza, że wszystkie z nich są dobre. Tak więc drugim kluczowym pojęciem ideacji jest myślenie konwergencyjne, czyli innymi słowy, umiejętność odróżnienia dobrych pomysłów od złych, polegająca na zgłębianiu potencjału różnych pomysłów i wyborze tych, na których należy się skupić. Umiejętność ta jest często pomijana i podważana, ale bez niej osoba kreatywna ryzykuje skupieniem się na niewłaściwych koncepcjach i podążaniem za tematami zastępczymi.

Ostatnim, najważniejszym etapem procesu twórczego jest etap walidacji. To moment, w którym twórca pokazuje światu wybrane pomysły i ocenia ich jakość oraz przydatność. Ale i tutaj czai się podstęp: jak oceniać pomysły, które są naprawdę nowe? Gdy ludzie spoglądają na coś prawdziwie innowacyjnego, a zarazem nieznanego, często wybierają stare rozwiązania. W ten sposób rzeczywiście kreatywny pomysł może zostać niesłusznie pogrzebany nie dlatego, że był zły, ale dlatego, że potencjalni użytkownicy nie byli jeszcze gotowi na jego przyjęcie 
(Greenberg, Buxton 2008). Dlatego też kolejną niezbędną umiejętnością, by odnieść sukces jako osoba kreatywna, jest wybranie narzędzia i momentu, w którym pomysł można poddać walidacji. Nie oznacza to, że każda koncepcja powinna być testowana dopiero po jej wdrożeniu. Wręcz przeciwnie - im wcześniej idee są przedstawiane potencjalnym odbiorcom, tym lepiej. Należy jednak podkreślić, że sposoby przedstawiania idei światu zewnętrznemu wymagają uważnego rozważenia, aby ich potencjał nie został przedwcześnie odrzucony. Jest to szczególnie ważne w przypadku pomysłów mających na celu podważenie obecnego status quo. Przykładowo mądrym pomysłem może być ujawnienie innowacyjnych koncepcji tylko grupie pierwszych odbiorców (early adopters), którzy z racji samej potrzeby poszukiwania nowości są bardziej skłonni dostrzec potencjał zupełnie nowej idei (Rogers 1962; Laukkanen, Pasanen 2008).

\section{Typy kreatywnych podejść}

Robert Sternberg (2006) zaproponował różne typy kreatywnych podejść. Niektóre procesy twórcze opierają się na przyjmowaniu aktualnych paradygmatów, a inne mają za zadanie je kwestionować. Efekty twórcze mające na celu wykorzystanie uprzedzeń są następujące:

$\rightarrow$ replikacja - próba pokazania, że dane rozwiązanie lub sposób myślenia jest właściwy. Replikacja ma na celu wzmocnienie, a nie kwestionowanie, obecnego status quo.

$\rightarrow$ redefinicja - próba przeorientowania danego pomysłu lub rozwiązania, spojrzenia na niego „innymi oczami” i z nowej perspektywy.

$\rightarrow$ inkrementowanie do przodu - próba posunięcia idei do przodu w kierunku, w którym już zmierza.

$\rightarrow$ zaawansowane inkrementowanie do przodu - próba przesunięcia idei w kierunku, w którym już zmierza, ale też poza punkt, do którego inni (np. konkurencja) są gotowi ją zaakceptować.

Przyjrzyjmy się teraz typom kreatywności, które odrzucają obecne paradygmaty i starają się je zastąpić:

$\rightarrow$ przekierowanie - tryb kreatywności mający na celu zmianę kierunku myślenia o danym wyniku, zejście ze szlaku, jakim obecnie podąża pomysł.

$\rightarrow$ rekonstrukcja - koncepcja przeniesienia idei tam, gdzie znajdowała się kiedyś. W pewnym sensie może być postrzegana jako 
rekonstrukcja przeszłości, dzięki czemu może posuwać się do przodu w innym kierunku niż ten, w którym podążała do tej pory.

$\rightarrow$ reinicjacja - proces twórczy mający na celu przeniesienie idei do innego, jeszcze nieosiągniętego punktu wyjścia, a następnie wyjście $z$ tego punktu.

Istnieje też trzeci rodzaj kreatywności, który ma na celu syntezę obecnych paradygmatów. To integracja, czyli próba połączenia dwóch lub więcej różnych sposobów myślenia o danej idei w jedną koncepcję. Chodzi o połączenie różnych podejść i sposobów myślenia.

O ile każde z tych kreatywnych podejść jest inne i odrębne, wielu twórców miesza je i łączy w swoich procesach twórczych. Można zacząć od replikacji, która prowadzi do integracji, a w końcu do rekonstrukcji. Jak już wcześniej wspomniano, sedno kreatywności tkwi w tym, aby próbować w nowy sposób myśleć i robić pewne rzeczy. Dlatego też kreatywność polega na poszukiwaniu nowych, wcześniej nieznanych sposobów na sprostanie nowemu wyzwaniu. Każdy człowiek na świecie jest do tego naturalnie predysponowany, jednak aby odnieść sukces, konieczne są pewne cechy charakteru twórczego.

\section{Kreatywny umysł}

Każdy odnoszący sukcesy twórca potrafi na wiele sposobów wyjść poza granice konwencjonalnego myślenia (Sternberg 1985). Wykazuje się przy tym syntetyczną umiejętnością postrzegania problemu na nowe sposoby, analityczną umiejętnością rozpoznawania pomysłów, które są warte realizacji, i kontekstualną umiejętnością przekonywania innych do swoich pomysłów. Jest to zestaw umiejętności niezbędnych dla osób kreatywnych. Jeśli dany człowiek posiada tylko umiejętności analityczne, potrafi skutecznie myśleć krytycznie, ale nie umie myśleć kreatywnie. Posiadanie jedynie umiejętności syntetycznych może prowadzić do skupienia się na pomysłach, które nie są wykonalne. Wykazywanie samych umiejętności kontekstualnych może sprawić, że pomysł zostanie zaakceptowany nie dlatego, że jest dobry, ale dlatego, że został dobrze przedstawiony.

Inną ważną cechą osoby kreatywnej jest posiadanie wystarczającej wiedzy o problemie, by zrozumieć przestrzeń twórczą. Z drugiej strony, nadmiar wiedzy może prowadzić do zawężonej perspektywy i sprawiać, że poruszamy się w kółko, a nie do przodu. W ten sposób wiedza może 
zarówno być pomocna w procesie twórczym, jak i go utrudniać (Frensch, Sternberg 1989).

Umiejętności można wykorzystywać na wiele różnych sposobów i stosować różne style myślenia. Styl myślenia to decyzja o tym, jak wykorzystać posiadane umiejętności. Szczególnie ważnym stylem w odniesieniu do kreatywności jest tzw. legislator, czyli skłonność do myślenia na nowe sposoby i decyzja o myśleniu w nowy sposób (Sternberg 1999). Styl ten różni się od umiejętności twórczego myślenia - pomaga kreatywnemu myślicielowi rozważać idee na poziomie globalnym i lokalnym, rozpoznawać, które pytania są ważne, a które takie nie są, mieć wytrwałość w pokonywaniu przeszkód i podejmować uzasadnione ryzyko (Lubart, Sternberg 1995). Wszystkie te aspekty definiują osoby kreatywne, które odnoszą sukces. Pozostaje zatem pytanie: czy są to cechy wrodzone, czy też mogą być rozwijane na przestrzeni lat? Czy jest to geniusz, czy umiejętność?

Carolyn Dweck poświęciła ponad dekadę na badania wymogów wstępnych do wykorzystania potencjału (również twórczego) z perspektywy dwóch podejść: trwałości i nastawienia na rozwój (Dweck 2012). Ludzie koncentrujący się na trwałości uważają, że ich talenty i zdolności są niezmienne. Mogą tyle, ile mogą, i to wszystko. Osoba kreatywna o takim nastawieniu może tak bardzo koncentrować się na swoim talencie, że nigdy nie uda jej się wykorzystać swojego potencjału.

Z drugiej strony ludzie nastawieni na rozwój myślą o talentach i zdolnościach jako czymś, co mogą rozwijać, jak o potencjale, który zostanie w pełni wykorzystany dzięki wysiłkowi, praktyce i nauczaniu. Uważają, że nie każdy ma taki sam potencjał i że nie każdy może być jak Leonardo da Vinci, ale rozumieją, że nawet on nie osiągnąłby sukcesu, gdyby nie lata wytężonej pracy. Przy nastawieniu na rozwój talent jest czymś, co się wykorzystuje i rozwija, a nie czymś, co pokazuje się światu i dzięki czemu osiąga się sukces (Dweck 2009). Innymi słowy, kiedy wierzymy, że możemy stać się mądrzejsi, możemy zrozumieć, że wysiłek czyni człowieka silniejszym. Dlatego jesteśmy skłonni poświęcić dodatkowy czas i starać się bardziej, dzięki czemu osiągamy więcej.

Najnowsze postępy w neurobiologii wydają się potwierdzać poprawność teorii Dweck, ponieważ wykazują, że ludzki mózg jest bardziej plastyczny, niż wcześniej zakładano (Green, Bavelier 2008). Dzięki treningowi tworzą się nowe połączenia między neuronami, wzmacniają istniejące i powstaje izolacja, która przyspiesza przekazywanie 
impulsów. Te odkrycia w zakresie neurobiologii pokazały, że możemy rozwijać nasze neurony dzięki podejmowanym działaniom, takim jak stosowanie dobrych strategii, zadawanie pytań, ćwiczenie i tworzenie dobrych nawyków.

\section{Refleksyjny praktyk}

Czym zatem istnieje przestrzeń rozwoju kreatywności? Często, gdy robimy coś (bez względu na to, czy jest to proces twórczy, czy coś innego), wykonujemy czynności w następującej kolejności: rozpoznanie, decyzja i dostosowanie. Jest to wiedza wykorzystywana w codziennych działaniach, zwana również wiedzą ukrytą (Polanyi 2009). Jednak często brakuje jednego etapu: refleksji. Z natury refleksja polega na umiejętności zadania sobie następujących pytań jednocześnie: „co to jest?" i „ „jak o tym myślałem?" (Schön 1987). Jest to umiejętność krytycznego myślenia na temat własnej praktyki twórczej i umiejętność zmieniania i udoskonalania jej. Pomaga to przeorganizować różne strategie twórcze oraz dostrzec wady i zalety poszczególnych podejść. Ale co najważniejsze, daje to początek eksperymentom na miejscu. Pozwala to osobie twórczej wymyślić i wypróbować nowe działania, aby zobaczyć, jak wpływają one na proces twórczy i jego wynik. Refleksyjna praktyka pomaga świadomie rozwijać twórcze myślenie i stale się rozwijać oraz stale przekształcać swoją twórczą praktykę.

Jednak sama refleksja (choć bardzo skuteczna sama w sobie) wymaga innego elementu: treningu kreatywności. Szkolenia z zakresu kreatywności przede wszystkim pomagają rozwijać kreatywność i dodają odwagi w kreatywnych poszukiwaniach (Meinel i in. 2018). Właściwie, im dana osoba czuje się mniej kreatywna, tym większy może być wpływ takiego treningu. Należy zdać sobie sprawę z tego, że kursy kreatywności mogą stanowić skuteczne podejście do rozwijania umiejętności twórczych. Warto jednak wziąć pod uwagę to, że w celu wprowadzenia trwałej zmiany w zakresie umiejętności twórczych szkolenie powinno trwać około pięciu dni, aby mogło przynieść trwałe efekty (Mathisen, Bronnick 2009). Ponadto takiemu treningowi powinna towarzyszyć refleksyjna praktyka, w ramach której jesteśmy w stanie ocenić swoje kreatywne zachowanie.

Nie można też zapomnieć o ostatnim aspekcie udanej praktyki twórczej, czyli o jej ocenie. Badania pokazują, że ocena postępów, a nie wynik, jest podstawą stymulowania kreatywności (Hochanadel, 
Finamore 2015). Taka koncepcja oceny odzwierciedla stymulowanie rozwoju umysłu, gdzie nadrzędne znaczenie ma samo zrozumienie, że kreatywność jest umiejętnością, którą należy rozwijać, a nie wrodzonym darem (O'Rourke i in. 2014). Innymi słowy: pomaga ludziom rozwijać kreatywną praktykę, aby stali się twórcami, jakimi chcieliby być. 


\title{
Czy wszyscy muszą być kreatywni?
}

\author{
Aldona Andrzejczak
}

Celem rozdziału jest krytyczna refleksja nad powszechnością wymagania kreatywności z perspektywy szkoły i rynku pracy. Punkt wyjścia stanowią rozważania dotyczące istoty kreatywności oraz możliwości jej pomiaru. Następnie zwrócono uwagę na kluczową rolę szkoły w odkrywaniu i rozwijaniu kreatywności uczniów ze szczególnym uwzględnieniem znaczenia dywergencyjnego stylu uczenia się zdefiniowanego przez Davida Kolba. W trzeciej części rozdziału przeanalizowano możliwość oceny i pomiaru w warunkach przedsiębiorstwa poziomu kreatywności pracowników i kandydatów do pracy. Mimo wykazania przydatności podejścia kompetencyjnego do diagnozy poziomu kreatywności pracowników w przedsiębiorstwie, wskazano jednak na nieadekwatność stosowania tego wymogu wobec wszystkich kandydatów do pracy.

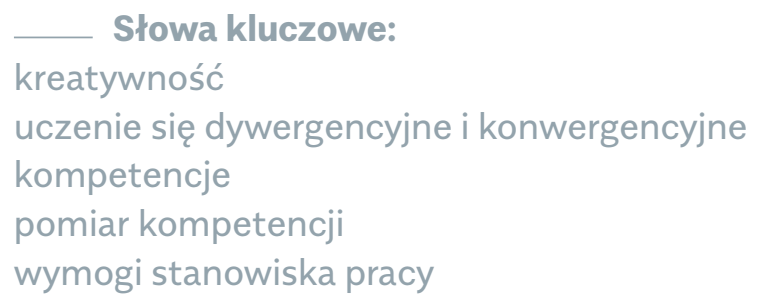




\section{Does everyone have to be creative?}

Aldona Andrzejczak

The aim of the article is a critical reflection on the common requirement of the creativity from the point of view of the school and the labor market. The starting point are considerations regarding the nature of creativity and the possibilities of its measurement. In the following part, attention was paid to the key role of the school in the discovery and development of students' creativity, focusing on the importance of the divergent learning style defined by David Kolb. The third part of the article deals with the possibility of assessing and measuring the level of creativity of employees and job candidates in the company. However, despite demonstrating the suitability of the competence approach to diagnosing the level of creativity of employees in the company, the inadequacy of applying this requirement to all candidates for work was indicated.

\section{Keywords:}




\section{Wprowadzenie}

Kreatywność stała się w ostatnich latach terminem bardzo popularnym, wymienianym jako jedna z najważniejszych kompetencji XXI w. Szybko zmieniający się współczesny świat stawia wymagania, którym często efektywnie sprostać może tylko osoba myśląca w sposób nietypowy, oryginalny, nowatorski, wykraczający poza schematy. Teresa Parczewska i Iwona Zwierzchowska wyliczają, że kreatywność stanowi klucz do postępu i rozwoju, źródło innowacji, ulepszeń i odkryć w różnych sferach życia społecznego, kulturowego i ekonomicznego, wpływa na sposób działania jednostki nie tylko w sytuacjach problemowych, lecz także w zwyczajnych, codziennych sytuacjach bycia w świecie (Parczewska, Zwierzchowska 2017, s. 34). Dlatego na każdym kroku słyszymy, jak ważną i potrzebną kompetencją jest kreatywność rozumiana jako zdolność do tworzenia nowych, lepszych rozwiązań napotykanych problemów. Bycie kreatywnym przynosi zarówno jednostce, jak i jej otoczeniu wiele korzyści. Ale co jeśli kreatywny pracownik stworzy rozwiązanie, które zagraża otoczeniu albo którego otoczenie nie akceptuje? Czy nadal jego kreatywność jest postrzegana jako coś pozytywnego? Czy rzeczywiście, jak twierdzi Edward de Bono, kreatywność jest umiejętnością i każdy może się jej nauczyć? Dlatego w tym miejscu warto przyjrzeć się krytycznie, na ile możliwe jest powszechne rozwijanie kreatywności, a na ile mamy do czynienia z modą na przypisywanie kreatywności nadmiernego znaczenia, zwłaszcza że możliwości precyzyjnego jej zdefiniowania i pomiaru są ograniczone i dyskusyjne. W szczególności należałoby zweryfikować zasadność coraz powszechniejszego wymagania kreatywności od kandydatów do pracy, przy ograniczonych możliwościach jej pomiaru przez pracodawców.

Pytanie postawione $w$ tytule wynika po części także z tego, że specjaliści dzielą się na tych, którzy zakładają, że każdy jest kreatywny i może dalej swoją kreatywność rozwijać, oraz tych, którzy raczej eksponują różnice między indywidualnym potencjałem do rozwijania kreatywności. W konsekwencji prowadzi to do podziału na osoby bardziej i mniej zdolne do kreatywności. Przy próbie odpowiedzi na postawione w tytule pytanie zostanie rozważona perspektywa edukacji, tzn. szkoły i nauczycieli, oraz rynku pracy, w szczególności pracodawców.

Ze względu na ograniczone ramy niniejszego opracowania kwestia definiowania kreatywności i sporu dotyczącego sposobu jej postrze- 
gania zostanie potraktowana bardzo ogólnie. W tym rozdziale kreatywność będzie analizowana nie tyle jako zbiór cech wyróżniających osobę kreatywną, ale jako zachowanie osoby cechującej się większą lub mniejszą kreatywnością.

\section{Postrzeganie i pomiar kreatywności}

Potocznie kreatywność jest często utożsamiana z twórczością. Jednak i w tej kwestii naukowcy są podzieleni. Dodatkowo niektórzy jako warunek kreatywności traktują powstanie dzieła (Fazlagić 2015, s. 19). Różnice występują także w sposobie wiązania kreatywności z człowiekiem. Jedni uważają, że kreatywność stanowi cechę człowieka, która podlega pomiarowi (Nęcka 2001). Inni kreatywność traktują jako rezultat oddziaływania wzajemnie ze sobą powiązanych cech (Karwowski 2010). Dla jeszcze innych kreatywność jest postawą i działaniem człowieka (Szmidt 2010).

Wiązanie kreatywności z twórczością zdecydowanie zawężałoby grono osób kreatywnych, gdyż twórcy określonych wytworów są zazwyczaj grupą elitarną, bardziej lub mniej wyjątkową, a rezultat ich twórczości powinien być oryginalny i nowatorski. Jak zauważa Krzysztof Szmidt, w nauce nie ma zresztą jednoznacznej definicji twórczości, gdyż rozumienie tego terminu ewoluowało w czasie i było różnie ujmowane, w zależności od przyjmowanej perspektywy badawczej (Szmidt 2013). Rozważano cechy osób twórczych, analizowano proces twórczy, badano uwarunkowania twórczości. Zauważono, że twórczość niekoniecznie łączy się z powstaniem dzieła, natomiast można mówić o twórczym myśleniu i działaniu, twórczych operacjach umysłowych. Można uznać, że każdy twórca jest kreatywny, ale nie każda osoba kreatywna jest twórcą. Tu pojawia się miejsce na określenie kreatywności. Podsumowując dotychczasowe rozważania, można przyjąć, że kreatywność stanowi proces umysłowy przejawiający się w zachowaniu człowieka, polegający na tworzeniu nowych idei, koncepcji lub nowych skojarzeń dzięki myśleniu nieschematycznemu, wymyślaniu nowych pomysłów i sposobów działania oraz zdolności do ich wdrażania. Myślenie kreatywne to myślenie prowadzące do uzyskania oryginalnych rozwiązań, które mogą być zastosowane. Tak więc kreatywność to zdolność do niestereotypowego myślenia i działania, która umożliwia elastyczne reagowanie na potrzeby środowiska i nowatorskie podejście do realizowanych zadań. 
Dla dalszych rozważań istotne znaczenie ma praktyczny sposób ujmowania kreatywności. W jakim stopniu jest to cecha intelektualna osoby, a w jakim cecha charakteru podlegająca kształtowaniu i wpływowi otoczenia. A może jest to wypadkowa różnych predyspozycji człowieka? Dla pełnego rozumienia pojęcia kreatywności zasadne wydaje się przywołanie teorii prezentowanej przez Roberta J. Sternberga (2006 za: Parczewska, Zwierzchowska 2017, s. 24), który wskazywał na sześć powiązanych ze sobą źródeł kreatywności. Są nimi:

$\rightarrow$ zdolności intelektualne,

$\rightarrow$ wiedza,

$\rightarrow$ style myślenia,

$\rightarrow$ osobowość,

$\rightarrow$ motywacja,

$\rightarrow$ otoczenie.

W polskiej literaturze (Karwowski 2010, s. 14) panuje pogląd, że kreatywność tworzą trzy wzajemnie powiązane cechy, tj.:

$\rightarrow$ zdolności twórcze,

$\rightarrow$ otwartość,

$\rightarrow$ niezależność.

Na podstawie różnych kombinacji natężenia powyższych cech Maciej Karwowski (2010, s. 16) stworzył osiem różnych konfiguracji cech, które można interpretować jako swoistą próbę kategoryzacji kreatywności:

$\rightarrow$ niska otwartość, niska niezależność, niskie zdolności twórcze odtwórczość, imitacyjność;

$\rightarrow$ niska otwartość, niska niezależność, wysokie zdolności twórcze - adaptacja, kreatywność zduszona;

$\rightarrow$ niska otwartość, wysoka niezależność, wysokie zdolności twórcze - kreatywność sztywna i buntownicza;

$\rightarrow$ niska otwartość, wysoka niezależność, niskie zdolności twórcze - destrukcyjny bunt;

$\rightarrow$ wysoka otwartość, wysoka niezależność, niskie zdolności twórcze - twórcza osobowość, twórczość samorealizująca się, pierwotna kreatywność bez szans na twórczość;

$\rightarrow$ wysoka otwartość, niska niezależność, niskie zdolności twórcze - wycofana ciekawość; 
$\rightarrow$ wysoka otwartość, niska niezależność, wysokie zdolności twórcze - kreatywność podporządkowana;

$\rightarrow$ wysoka otwartość, wysoka niezależność, wysokie zdolności twórcze - pełna kreatywność.

Powyższe podejście do kreatywności wydaje się szczególnie inspirujące. Dzięki precyzyjnemu określeniu stopnia otwartości i niezależności poszczególnych osób oraz przejawiania przez nie zdolności twórczych pozwala bowiem mierzyć poziom i charakter ich kreatywności.

\section{Rola szkoły w rozwijaniu kreatywności}

Skoro ludzie różnią się między sobą pod względem natężenia cech związanych z kreatywnością, to warto zaznaczyć, że właśnie w szkole występują idealne warunki, aby kreatywność konkretnych uczniów odkrywać i rozwijać. Jednak rozwijanie kreatywności wymaga szczególnego podejścia do realizacji podstawowego zadania szkoły, jakim jest przygotowanie uczniów do życia w otaczającym świecie. Jak pokazuje raport z badań zamówionych przez Ministerstwo Przedsiębiorczości i Technologii, polska szkoła nie rozwija kreatywności uczniów, czemu na przeszkodzie stoi głównie powierzchowne uczenie się, polegające na pamięciowym przyswajaniu dużych partii materiału, podział na przedmioty, faworyzowanie w szkole uczniów zdyscyplinowanych i potulnych oraz zabijanie spontaniczności w działaniu (Fazlagić 2018a).

Ogólnie bariery utrudniające w szkole rozwijanie kreatywności uczniów można podzielić na związane z tradycyjnym postrzeganiem roli szkoły oraz trudności realizacyjne (czas, kompetencje i motywacja nauczycieli, warunki materialne w szkole). Warto jednak zauważyć, że szkoły, a zwłaszcza niektórzy nauczyciele, w ostatnich dekadach podejmują też wysiłki zmierzające do tworzenia klimatu dla rozwoju kreatywności uczniów. Wydaje się, że rozwiązanie zasygnalizowanego problemu w całej jego złożoności lepiej jednak pozostawić specjalistom, tzn. władzom oświatowym i nauczycielom posiadającym w tym zakresie znaczne osiągnięcia. Przydatne mogą okazać się rekomendacje przedstawione w raporcie Szkoła dla innowatora. Kształtowanie kompetencji proinnowacyjnych.

Związek kreatywności ze sposobem uczenia się i nauczania jest oczywisty ze względu na sposób myślenia. Występuje wiele sposobów 
podejścia do podziału rodzajów myślenia. Warto odwołać się w tym miejscu do wprowadzonego przez Joya Paula Guilforda w latach 60. $X X$ w. podziału na myślenie konwergencyjne i dywergencyjne. Myślenie konwergencyjne (inaczej zbieżne) cechuje się poszukiwaniem jednego właściwego rozwiązania, gdyż każdy problem ma swoją przyczynę. Myślenie konwergencyjne hamuje zatem kreatywność. Z kolei myślenie dywergencyjne (inaczej rozbieżne) pojawia się w przypadku istnienia wielu możliwych rozwiązań. Oznacza więc tworzenie kilku rozwiązań tego samego problemu i wyjście poza istniejące schematy i wzorce rozumowania. $Z$ punktu widzenia kreatywności ma ono zatem fundamentalne znaczenie. Nietrudno jednak skonstatować, że o ile małe dzieci mają skłonność do myślenia dywergencyjnego, to w szkole wymagania programowe i po części testowy system sprawdzania osiągnięć uczniów sprzyjają utrwalaniu myślenia konwergencyjnego (Szmidt 2013).

W późniejszych etapach edukacji, kiedy uczeń staje się bardziej samodzielny, istotne znaczenie ma wypracowany na wcześniejszych etapach edukacji styl uczenia się. Przydatny zarówno dla nauczycieli, jak i dla uczniów jest tu cykl uczenia się opracowany przez amerykańskiego psychologa Davida Kolba (1984). Cykl ten obejmuje cztery etapy:

$\rightarrow$ konkretne przeżycie,

$\rightarrow$ refleksyjną obserwację,

$\rightarrow$ abstrakcyjne uogólnianie,

$\rightarrow$ aktywne eksperymentowanie.

Badania nad procesem uczenia się i występującymi kombinacjami sposobów uczenia się pozwoliły na wyodrębnienie czterech stylów uczenia się:

$\rightarrow$ Styl konwergencyjny odznacza się wysoką umiejętnością praktycznego stosowania wiedzy teoretycznej. Wymaga więc posiadania zdolności do abstrakcyjnego myślenia i aktywnego eksperymentowania.

$\rightarrow$ Styl dywergencyjny opiera się bardziej na wykorzystaniu konkretnego przeżycia i refleksyjnej obserwacji. Wymaga wyobraźni, postrzegania danego problemu z różnych perspektyw, zaangażowania emocjonalnego. 
$\rightarrow$ Styl asymilacyjny opiera się na dominacji abstrakcyjnego uogólniania i refleksyjnej obserwacji. Styl ten prowadzi najczęściej do logicznego i precyzyjnego porządkowania zagadnień oraz tworzenia modeli i teorii.

$\rightarrow$ Styl akomodacyjny, w którym dominuje aktywne eksperymentowanie i konkretne przeżycie, cechuje się zaangażowaniem we wdrażanie planów i poszukiwanie nowych doświadczeń.

Ludzie różnią się pod względem dominującego stylu uczenia się, ale zgodnie $z$ cyklem uczenia się $w$ praktyce $w$ różny sposób kompensują swoje słabsze strony, np. ucząc się w grupie albo podejmując działania zmierzające do zredukowania własnych ograniczeń. Natomiast osoby charakteryzujące się dywergencyjnym stylem uczenia się w praktyce będą wykazywały się wyższą kreatywnością. Brak przewagi tego stylu w grupach menedżerów wskazuje jednak, że nie musi to stanowić przeszkody w karierze zawodowej.

Rodzi się pytanie, jak można w szkole tworzyć warunki sprzyjające rozwijaniu dywergencyjnego stylu uczenia się. Przydatne może się tu okazać poznanie ograniczeń w rozwoju kreatywnego myślenia. Krzysztof Szmidt (2010) zwrócił uwagę na występowanie barier zarówno poznawczych, jak i emocjonalno-motywacyjnych w rozwoju kreatywności (tabela 1). Niektóre z nich wydają się silnie powiązane z cechami osobowymi ucznia, ale większość można ograniczać poprzez odpowiednie organizowanie procesu uczenia się.

Tabela 1. Główne bariery poznawcze i emocjonalno-motywacyjne w rozwoju kreatywności

\begin{tabular}{l|l}
\multicolumn{1}{c|}{ BARIERY POZNAWCZE } & \multicolumn{1}{c}{ BARIERY EMOCJONALNO-MOTYWACYJNE } \\
\hline$\rightarrow$ mała spostrzegawczość & $\rightarrow$ lęk przed nieznanym \\
$\rightarrow$ sztywność myślenia & $\rightarrow$ niechęć do nowości \\
$\rightarrow$ brak otwartości na nowe treści & $\rightarrow$ brak tolerancji dla wieloznaczności \\
$\rightarrow$ przedwczesne zamykanie sytuacji & $\rightarrow$ brak wytrwałości i umiejętności odraczania \\
problemowej & gratyfikacji (uzyskania nagród) \\
$\rightarrow$ ślepota na rzeczy do zrobienia (naprawienia, & $\rightarrow$ lęk przed oceną i ośmieszeniem się \\
modyfikacji) & $\rightarrow$ lęk przed ryzykiem \\
$\rightarrow$ dominacja wyobraźni odtwórczej & $\rightarrow$ przesadny konformizm i uleganie grupie \\
\hline
\end{tabular}

Źródło: Szmidt 2010, s. 22. 
Można zauważyć, że podatne na oddziaływanie nauczyciela i szkoły wydają się bariery zarówno emocjonalno-motywacyjne, jak i - może w nieco mniejszym stopniu - poznawcze. Poprzez formy i metody pracy na lekcjach oraz na zajęciach pozalekcyjnych można próbować stopniowo je ograniczać lub eliminować. Warto przy tym zaznaczyć, że nie chodzi o wyróżnianie uczniów bardziej kreatywnych, ale o wytworzenie wśród wszystkich uczniów atmosfery wolnej od obaw przed ośmieszeniem oraz zachęcanie ich do ciekawości i odkrywania wielu możliwych rozwiązań, zgłaszania i rozwijania pomysłów oraz wyciągania wniosków, dzięki czemu uczniowie stopniowo zaadaptują się do bardziej kreatywnego rozwiązywania problemów.

\section{Kreatywność jako wymóg pracodawcy wobec pracowników}

W dzisiejszych czasach w różnych sytuacjach bardzo eksponuje się znaczenie i potrzebę kreatywności. Ma to swoje uzasadnienie w zmianie paradygmatu rozwoju, polegającej na przejściu do gospodarki opartej na wiedzy i innowacjach. Kwestia kreatywności stała się tak powszechne, że na wszelki wypadek większość pracodawców, formułując swoje wymagania wobec przyszłych pracowników, oczekuje od nich także kreatywności. W tym miejscu nasuwają się dwa zasadnicze pytania. Po pierwsze, czy pracodawcy posiadają narzędzia do oceny kreatywności? Skoro poważne problemy ze zdefiniowaniem kreatywności mają naukowcy, to jak sobie z tym wymogiem radzą pracodawcy? Drugie pytanie dotyczy adekwatności wymogu kreatywności do charakteru realizowanych zadań.

W odniesieniu do odpowiedzi na pierwsze pytanie: praktyka zarządzania zasobami ludzkimi w organizacjach podsuwa rozwiązanie polegające na zastosowaniu podejścia kompetencyjnego. Zgodnie z regułami sztuki proces pozyskiwania nowego pracownika rozpoczyna się od analizy obowiązków i przygotowania opisu stanowiska, na który składają się opis pracy i opis wymagań stanowiska, nazywany niekiedy profilem wymagań kompetencyjnych. Ograniczając się do najważniejszych elementów tego opisu, można wymienić m.in.: zadania realizowane na danym stanowisku, zależności i relacje służbowe z innymi stanowiskami, zakres odpowiedzialności za decyzje i wyniki oraz urządzenia i aparaturę wraz z oprogramowaniem. Informacje zawarte $w$ takim opisie służą do sprecyzowania, jaka wiedza, umiejęt- 
ności, motywacja, predyspozycje fizyczne, społeczne i psychiczne są potrzebne do efektywnego wykonywania pracy na danym stanowisku. Wymienione elementy są czynnikami warunkującymi sprawność zawodową pracownika. Jednak $w$ firmach, $w$ których nadal dominuje bardzo tradycyjne podejście do rekrutacji pracowników, uwagę zwraca się głównie na sformułowanie wymagań formalnych, tj. wykształcenie, określona liczba lat doświadczenia na podobnym stanowisku, ewentualnie konkretne certyfikaty potwierdzające określone kwalifikacje. Do nich najczęściej dopisuje się kilka wymagań dotyczących cech pożądanego kandydata. Jednak to nieprofesjonalne podejście do rekrutacji pracowników jest stopniowo zastępowane przez podejście oparte na profilach kompetencyjnych.

Pojęcie kompetencje wyparło wykorzystywane wcześniej kwalifikacje, będące przeważnie jedynie formalnym potwierdzeniem zaliczonych form edukacji szkolnej. Praktyczna przydatność kompetencji polega na tym, że nawiązują one do sposobu, w jaki zachowują się pracownicy w różnych sytuacjach zawodowych. Kompetencje mogą być więc traktowane jako miara wskazująca, w jakim stopniu pracownik w określonej sytuacji związanej z pracą wykorzystuje swoje zasoby intelektualne, emocjonalne, moralne. Kompetencje wskazują, jak w zachowaniach organizacyjnych przejawia się wewnętrzny potencjał pracownika, umożliwiający mu adaptację do wyzwań otoczenia i uczenie się. Pojęcie kompetencji doczekało się licznych definicji (Filipowicz 2016, s. 44). Myślenie w kategoriach kompetencji zakłada, że człowiek dąży do wykorzystania swoich osobistych predyspozycji i zgromadzonego doświadczenia oraz nieustannie uczy się, jak zwiększać własną efektywność (Filipowicz 2016, s. 17). Przedmiotem dociekań badawczych jest więc zidentyfikowanie czynników, które kształtują kompetencje. Definiując je, uwzględnia się przykładowo wiedzę, umiejętności, uzdolnienia, style działania, osobowość, wyznawane zasady, zainteresowania i inne cechy, które używane i rozwijane w procesie pracy prowadzą do osiągania rezultatów zgodnych ze strategicznymi zamierzeniami przedsiębiorstwa (Rostkowski, Szczęsna 2004, s. 90). Trzeba podkreślić, że istotą zastosowania kompetencji w zarządzaniu zasobami ludzkimi jest podejście behawioralne do kompetencji, tzn. skoncentrowanie się na opisie zachowania potrzebnego do kompetentnego, właściwego wykonywania zadań. Kompetencje jako takie nie są obserwowalne, ale dzięki zachowaniu pracownika można 
wnioskować, na jakim poziomie daną kompetencję posiada. Dlatego z praktycznego punktu widzenia można przyjąć, że kompetencje to dyspozycje w zakresie wiedzy, umiejętności i postaw, pozwalające realizować zadania zawodowe na odpowiednim poziomie (Filipowicz 2016, s. 46). Podsumowując, podejście kompetencyjne (zarządzanie oparte na kompetencjach) może być praktycznym sposobem poradzenia sobie $z$ dylematem oceny kompetencji pracownika w zakresie kreatywności.

W polskiej literaturze Tadeusz Oleksyn (2006), charakteryzując najważniejsze kompetencje wymagane na rynku pracy, wymienił wśród nich kreatywność i innowacyjność. Podkreślił również, że nie są one tożsame, ale mogą być rozpatrywane łącznie. Kreatywność wiązał z twórczością, czyli tworzeniem czegoś nowego i oryginalnego, natomiast innowacyjność łączył z elementami zarówno twórczymi, jak i odtwórczymi, gdyż definiował ją jako wprowadzanie nowych lub niekoniecznie nowych rzeczy do praktyki organizacji (Oleksyn 2006, s. 59).

Zgodnie z zasadami kompetencja "kreatywność" powinna mieć swoją definicję, a następnie wymiary, tj. opisy zachowania pracownika zachowującego się kolejno: mało kreatywnie, bardziej kreatywnie, aż do bardzo kreatywnie - w zależności od przyjętej skali addytywnej lub rozwojowej. Jak bardzo jest to trudne, tzn. subiektywne, mało konkretne i sprawdzalne, działanie, niech posłuży przykład. Poniżej definicje kreatywności skonstruowane przez studentów drugiego roku studiów magisterskich na specjalności zarządzanie zasobami ludzkimi:

$\rightarrow$ Umiejętność twórczego myślenia, rozwiązywanie problemów w sposób twórczy i nietypowy, bogata wyobraźnia, ekspresyjność, oryginalność w działaniu, niezawodne rozwiązania.

$\rightarrow$ Umiejętność kreowania nowych rzeczy i pomysłów. Zdolność dzielenia się swoją wiedzą i pomysłami z innymi. Osoba mająca niestandardowe pomysły i rozwiązania, umiejąca współpracować z grupą.

$\rightarrow$ Umiejętność twórczego myślenia, nowatorskie podejście, otwartość na trendy i nowinki branżowe, propagowanie oryginalnych, nowych rozwiązań, odejście od tradycyjnego myślenia, abstrakcyjne myślenie. 
Definicje te są podobne i pokazują powiązanie z innymi kompetencjami, np. umiejętnością współpracy w grupie czy dzielenia się wiedzą. Definicje kreatywności stworzone przez studentów warto skonfrontować z definicją wypracowaną na potrzeby projektu badawczego, a następnie ocenioną przez 135 przedsiębiorców z Polski, Słowacji, Słowenii i Finlandii. Była ona następująca: „Kreatywność to zespół wiedzy, umiejętności i postaw praktycznego wykorzystania technik twórczego myślenia w celu tworzenia oryginalnych i użytecznych rozwiązań problemów, wypracowania nowych koncepcji lub nowych powiązań z istniejącymi już ideami i koncepcjami". W definicji tej wyodrębniono trzy zachowania: zdolność do tworzenia użytecznych rozwiązań, zdolność do twórczego myślenia i wypracowywania nowych koncepcji oraz zdolność do generowania oryginalnych pomysłów (Jędrzejczyk 2017, s. 17). Można zauważyć, że propozycje studentów są zbliżone do tych wypracowanych w gronie fachowców, co oznacza, że pracodawcy mogą definiować kreatywność w formie pożądanych zachowań.

Dużo ciekawsze jest jednak to, jak studenci zwymiarowali poszczególne poziomy posiadania kompetencji „kreatywność". Dla ułatwienia opisy zachowania zostały ujęte w tabeli 2. Niezależnie od nasuwających się uwag szczegółowych i możliwości udoskonalenia propozycji zawartych w tabeli 2 (wypracowanych w krótkim czasie przez studentów na zajęciach), wynika z nich jasno, że na poziomie konkretnej organizacji jest możliwe zdefiniowanie i zwymiarowanie kompetencji kreatywności przy wykorzystaniu podejścia behawioralnego. Wymaga to pewnego wysiłku, czasu i fachowości, ale opisanie zachowań pracowników wskazujących na różny poziom kreatywności w pracy jest możliwe. Istotne znaczenie będzie tu miało adekwatne dla danej organizacji zdefiniowanie kreatywności, a następnie przyjęcie odpowiedniej skali. Na podstawie tak przygotowanego opisu kompetencji można wyznaczać określony poziom wymagań kreatywności dla danego stanowiska, oceniać poziom kompetencji kandydata na podstawie przygotowanych zadań w ramach assessment center ${ }^{1}$ oraz oceniać zmiany poziomu kompetencji u pracowników w trakcie ocen okresowych. 

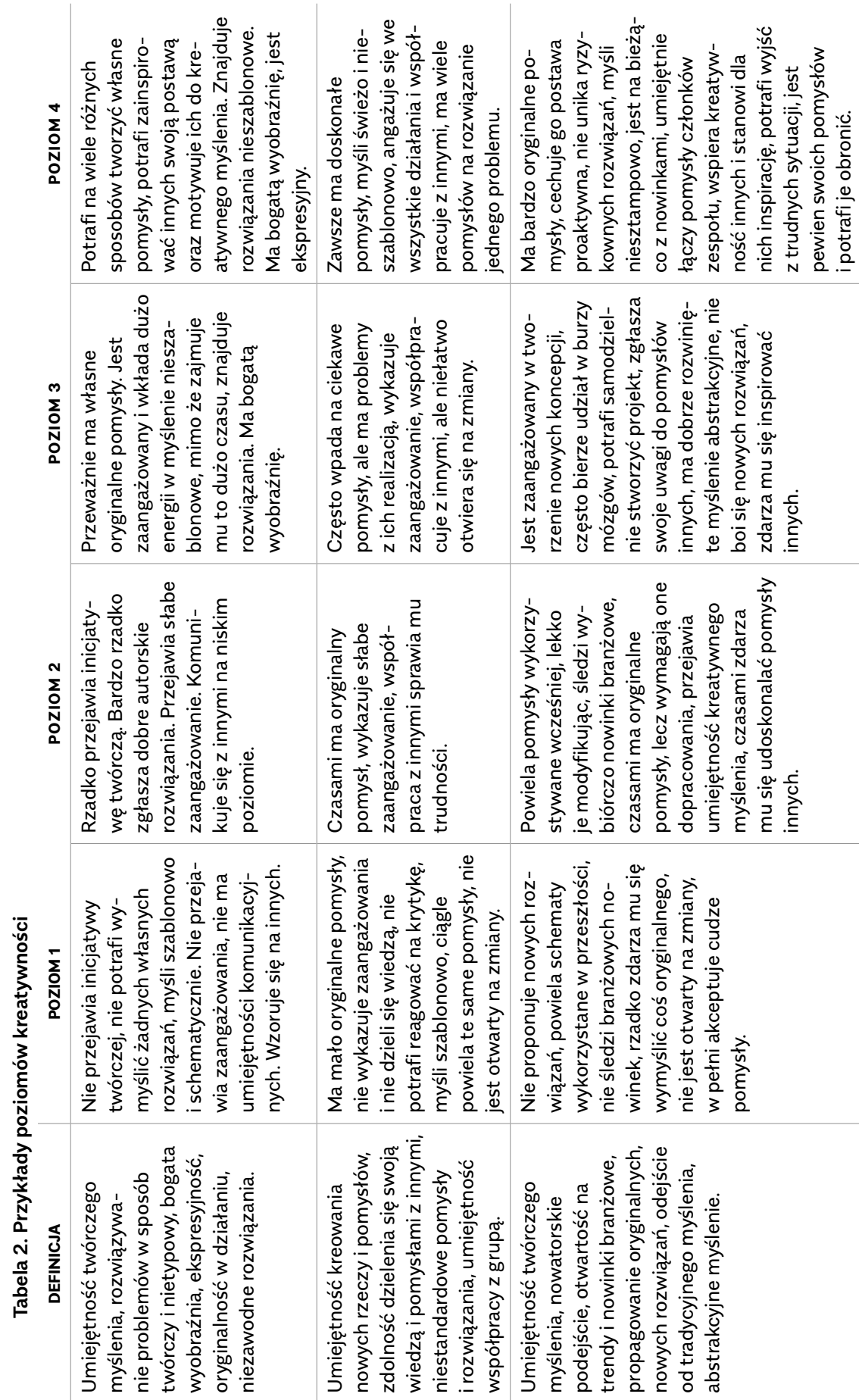

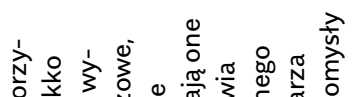

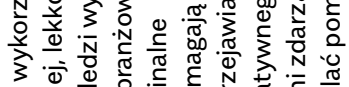

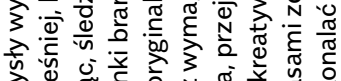

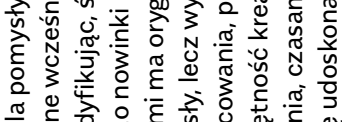

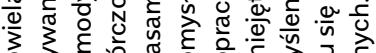

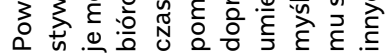

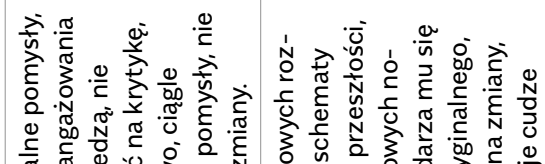

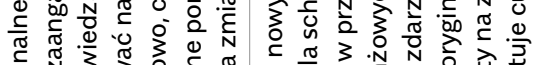

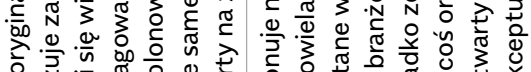

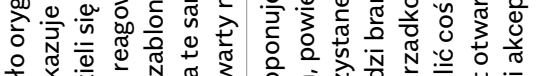

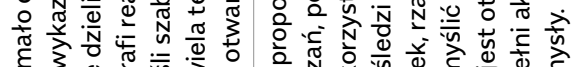

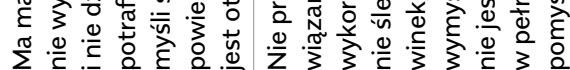

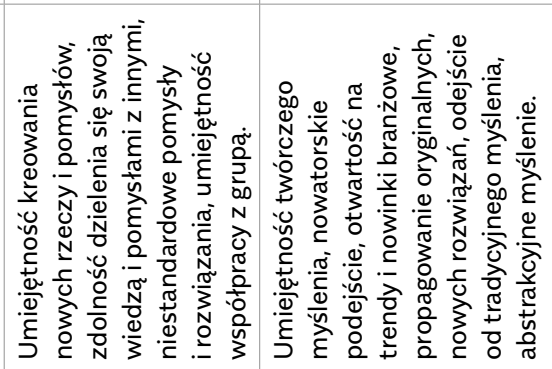


Zatem na pierwsze z postawionych pytań: „Czy pracodawcy posiadają narzędzia do oceny kreatywności?", można odpowiedzieć twierdząco. Nie przedstawiono konkretnych przykładów pochodzących z praktyki gospodarczej, ale wykazano, że dla pracodawcy wykorzystującego w zarządzaniu podejście oparte na kompetencjach zdefiniowanie i zwymiarowanie tej kompetencji jest możliwe. Wątpliwość może budzić jedynie stopień upowszechnienia w praktyce zarządzania kompetencjami. Jak wynika z badań przeprowadzonych w Polsce w 2013 r. na próbie 941 przedsiębiorstw, prawie połowa z nich (47,6\%) już wprowadziła profile kompetencyjne, a kolejnych $15 \%$ było $w$ trakcie ich wdrażania. Jednak $18,3 \%$ badanych firm nie planowało wdrożenia profili kompetencyjnych (Sienkiewicz 2013, s. 53).

Drugim analizowanym zagadnieniem jest to, czy wymóg kreatywności od kandydatów jest adekwatny do charakteru realizowanych zadań? Dane z tabeli 2 wskazują, że we wszystkich opisach przewidziano sytuację, w której pracownik nie przejawia zachowania kreatywnego $w$ pracy $^{2}$. Wynika to z przeświadczenia, że istnieje sporo stanowisk pracy, na których wymaga się precyzyjnego przestrzegania norm postępowania i podporządkowania się przyjętym zasadom, a wszelkie odstępstwa od ustalonej procedury byłyby szkodliwe lub wręcz niebezpieczne - są to stanowiska niewymagające kreatywności lub na których kreatywność może być wręcz przeszkodą. Można tu przywołać chociażby przykłady niektórych stanowisk laboratoryjnych, medycznych, urzędniczych czy wykonawczych zaangażowanych w procesach produkcyjnych lub usługowych. Nie chcielibyśmy, aby nasz samochód był składany przez mechanika mającego kreatywne podejście do montowania kolejnych elementów. Wolimy, aby ściśle przestrzegał on wszelkich procedur. Nie zmienia to jednak faktu, że oczekujemy, by projektanci samochodów byli pracownikami bardzo kreatywnymi w zakresie aspektów zarówno technicznych, jak i dotyczących designu tworzonych produktów. Na niektórych stanowiskach zdecydowanie większą wagę przywiązuje się do znajomości metod pracy, określanych fachowością, która będzie przejawiać się w skru- 
pulatności, dokładności, precyzji, niezawodności działania. Podobny pogląd prezentował Tadeusz Oleksyn, powołując się na Petera Druckera, który twierdził, że nie należy stawiać celów innowacyjnych przed pracownikami: odpowiedzialnymi za utrzymanie ruchu, eksploatację i optymalizację istniejących procesów. Twierdził, że nie wszyscy pracownicy muszą być "rozwojowi”, gdyż w organizacji potrzebne są różne typy pracowników, w tym także "konie pociągowe" (Oleksyn 2006, s. 60). Warto również odwołać się do opinii 135 menedżerów uczestniczących w projekcie badawczym, spośród których tylko $45 \%$ uznało kreatywność za bardzo potrzebną, a 33,6\% za potrzebną w pracy. Co ciekawe, przydatność kreatywności została najwyżej oceniona przez menedżerów polskich, a najniżej przez przedsiębiorców fińskich. Jak stwierdza Waldemar Jędrzejczyk (2017), badanie wykazało, że im wyższy poziom kreatywności kraju, tym niżej oceniono przydatność kreatywności jako kompetencji zawodowej.

Dlaczego więc pracodawcy coraz częściej oczekują od pracowników kreatywności? Można przyjąć, że stanowiska pracy różnią się charakterem zadań i że niektóre $z$ nich wymagają sprawnego rutynowego wykonywania obowiązków. Pojawia się jednak także kwestia sytuacji nietypowych, nadzwyczajnych. W obecnych czasach zdarzają się one coraz częściej i wymagają działań niestandardowych, znajdowania nisz popytowych, tworzenia nowych propozycji dóbr i usług. Nasuwa się wobec tego pytanie, czy pracodawcy, formułując wymóg kreatywności wobec kandydatów do pracy, zawsze rzeczywiście mają na myśli kreatywność. Być może kreatywność jest przez nich rozumiana jako postawa przeciwstawna bierności i bezradności. Wobec tego być może w istocie bardziej zależy im na przedsiębiorczej postawie pracownika, który podejmuje działania, kierując się interesem organizacji i realizacją jej celów, ale niekoniecznie musi być w tym kreatywny. Jakoś trudno wyobrazić sobie życie w otoczeniu osób zawsze kreatywnych, natomiast oczekujemy, że nie będą nas otaczać ludzie bezradni i bierni. To jednak nie to samo co wymóg, aby wszyscy byli kreatywni.

Inną kwestią związaną z rosnącą popularnością wymogu kreatywności jest wzrost znaczenia usług wykorzystujących wiedzę pracowników, tzw. usług wiedzochłonnych. To właśnie tego rodzaju przedsiębiorstwa w szczególny sposób eksponują znaczenie kreatywności jako wymaganej kompetencji zawodowej. O ile w przywoływanych już badaniach na próbie 941 firm średnio $26 \%$ badanych wskazywało na 
kreatywność jako kompetencję wymaganą od kandydatów do pracy, o tyle w przypadku firm dostarczających usługi wiedzochłonne było to $33 \%$ (Sienkiewicz 2013, s. 69).

\section{Podsumowanie}

Kreatywność jest obecnie zachowaniem bardzo pożądanym w różnych sytuacjach życiowych. Cenią ją zwłaszcza pracodawcy oczekujący, że pracownicy w momentach nietypowych wykażą się inicjatywą i zaproponują nowe rozwiązanie problemu. Jednocześnie formułowane są liczne opinie krytyczne o tym, że szkoła nie kształtuje w wystarczającym stopniu kreatywnej i innowacyjnej postawy u uczniów. Celem artykułu była krytyczna refleksja nad zasadnością powszechnego wymogu kreatywności formułowanego pod adresem nauczycieli i szkół, a także kandydatów do pracy i pracowników.

Krótki przegląd sposobów ujmowania kreatywności w literaturze pozwolił na przyjęcie takiej definicji kreatywności, która opierała się na zachowaniu. Ma to istotne znaczenie dla pomiaru kreatywności wykorzystującego podejście kompetencyjne, które jest szczególnie przydatne w warunkach przedsiębiorstwa. Dzięki temu możliwe było udzielenie odpowiedzi na jedno z postawionych w tekście pytań: „Czy pracodawcy dysponują narzędziami do oceny kreatywności pracowników?". Wykorzystana przy tej okazji kreatywność studentów, którzy przygotowują się do pracy w działach zarządzania zasobami ludzkimi, dowiodła, że możliwe jest zdefiniowanie i zwymiarowanie kompetencji kreatywności na potrzeby konkretnej organizacji. Rezultaty ćwiczenia przeprowadzanego $w$ warunkach zajęć, w oderwaniu od prawdziwego kontekstu organizacyjnego, nie są w pełni satysfakcjonujące, ale wskazują, że fachowcy są w stanie przygotować dla organizacji narzędzie diagnozujące kreatywność. Przytoczone wyniki badań w przedsiębiorstwach w Polsce potwierdziły, że większość badanych wdrożyła lub wdraża profile kompetencyjne do zarządzania, z czego $26 \%$ wymaga kreatywności od zatrudnionych pracowników.

Na postawione w tytule pytanie: „Czy wszyscy muszą być kreatywni?" można sformułować następującą odpowiedź: nie wszyscy muszą być $w$ tym samym stopniu kreatywni, ale w szkole powinno dążyć się do rozwijania kreatywności u każdego ucznia. Natomiast nie wszystkie stanowiska pracy wymagają od pracowników kreatywności, wobec czego powszechność tego wymogu wobec pracowników jest nieco na 
wyrost. Zmienia się natomiast struktura przedsiębiorstw i głównie w firmach świadczących usługi, w tym tzw. usługi wiedzochłonne, będzie wzrastać znaczenie kreatywności.

Kreatywność rozwinięta w szkole może być wykorzystywana w różnych innych aspektach życia we współczesnym świecie. Dlatego szkolnictwo wymaga zmian programowych polegających nie na poszerzaniu, ale zredukowaniu treści oraz systemowych zmian organizacyjnych, aby stworzyć nauczycielom lepsze warunki do redukowania poznawczych i emocjonalno-motywacyjnych barier kreatywności uczniów. Dużą rolę może tu odegrać rozwijanie dywergencyjnego myślenia i stylu uczenia się u uczniów. W odniesieniu do pracodawców można stwierdzić, że profesjonalizacja procesów personalnych w organizacjach, w tym oparcie ich na podejściu kompetencyjnym i stworzeniu profili kompetencyjnych stanowisk pracy, może stanowić ważny krok w urealnieniu wymagań wobec kandydatów do pracy oraz może sprzyjać bardziej sprawiedliwej ocenie stopnia dopasowania kompetencji pracownika do wymagań jego stanowiska pracy. Tym samym przyczyni się to do lepszego wykorzystania potencjału pracowników oraz udoskonalenia procesów planowania ich dalszego rozwoju. 



\section{Kreatywność osób dojrzałych \\ i czynniki sprzyjające jej wzbudzaniu}

Grażyna Bartkowiak

Przedmiotem rozdziału jest problematyka kreatywności osób dojrzałych. W pierwszej części, po ustaleniu definicji kreatywności, autorka analizuje psychologiczne uwarunkowania zachowań kreatywnych, rozpatrując zjawisko jako kategorię podmiotową, a więc charakteryzującą osoby o określonych cechach osobowości, i wskazując na mechanizm zachowań kreatywnych. W dalszej części została omówiona specyfika funkcjonowania osób w wieku dojrzałym w kontekście ich życia, a następnie kreatywność w odniesieniu do osób dojrzałych. W ostatniej części poruszono zagadnienia możliwości stymulowania kreatywnego myślenia u seniorów z perspektywy poszczególnych psychologicznych koncepcji człowieka, a także w perspektywie systemowej, wymagającej wprowadzenia określonych rozwiązań w praktyce dnia codziennego.

\section{__ Słowa kluczowe:}




\section{Creativity of elderly people and factors conducive to its stimulation}

Grażyna Bartkowiak

The subject of the article's deliberations is the issue of creativity of elderly people. In the first part, after defining the definition of creativity, the authoress analyzes the psychological determinants of creative behavior, considering the phenomenon as a subjective category, thus characterizing people with specific personality characteristics and pointing to the "mechanism of creative behavior". The next part discusses the specificity of functioning of elderly people in the context of their lives, and then creativity in relation to elderly people. The last part of the article discusses the issues of the possibility of stimulating creative thinking in seniors from the point of view of individual psychological concepts of a human being, as well as in the systemic perspective, requiring the implementation of specific solutions of everyday practice.

\section{Keywords:}




\section{Wprowadzenie}

Czynniki warunkujące kreatywność osób dojrzałych i możliwość jej stymulowania ${ }^{1}$ były już przedmiotem licznych opracowań, podejmowanych zarówno na gruncie literatury polskiej, jak i anglojęzycznej. Mimo to problematyka ta stale jeszcze wydaje się inspirująca i godna kolejnych analiz. Dzieje się tak, ponieważ dotyczy zagadnień szczególnie istotnych zarówno z perspektywy rozwoju indywidualnych biografii osób dojrzałych, jak i funkcjonowania systemu społeczno-gospodarczego, mającego na celu przeciwdziałanie wykluczeniu osób dojrzałych, tak by zagospodarować tkwiący w nich potencjał intelektualny i społeczny. Drugim powodem jest ranga kreatywności jako czynnika dynamizującego naszą cywilizację.

\section{Kreatywność - ustalenia definicyjne}

Kreatywne myślenie polega na podejmowaniu świadomych wysiłków zmierzających do poznawania i zrozumienia określonych zależności w otaczającej nas rzeczywistości, a także do rozwiązywania problemów i kierowania sobą. W rezultacie chodzi o analizowanie i diagnozowanie rzeczywistości, a w konsekwencji o przewidywanie i planowanie oraz podejmowanie działań zmierzających do osiągnięcia zamierzonych, często ambitnych celów.

Ken Robinson i Lou Aronika (2009) uważają, że kreatywność polega nie tylko na twórczym rozwiązywaniu problemów, lecz także na ich dostrzeganiu i wynajdywaniu. Twierdzą, po pierwsze, że bycie kreatywnym wiąże się z działaniem, czyli z robieniem czegoś konkretnego a dodatkowo nowego. Ludzie nie są abstrakcyjnie kreatywni, stają się kreatywni dopiero podczas robienia czegoś praktycznego, np. w procesie rozwiązywania jakiegoś problemu, w projektowaniu, aktywnym uczestnictwie w kulturze, biznesie itp. Nie można być kreatywnym, jeżeli się czegoś nie robi, czyli w tym aspekcie kreatywność, a więc twórcze myślenie, zasadniczo różni się od wyobraźni, marzeń czy wizualizacji (de Bono 2008). W odróżnieniu od tych ostatnich kreatywność polega nie tylko na wyobrażaniu sobie i tworzeniu nowych możliwości, lecz także na rozważaniu sposobów ich realizacji. W tym sensie kreatywność jest "stosowaną wyobraźnią" (Bieniok 2014, s. 48). 
W naukach społecznych wskazuje się na powiązanie (a niekiedy tożsamość) innowacyjności z twórczością ${ }^{2}$ (Kozielecki 1992) i kreatywnością (Altszuller 1972; Altszuller 1983; Nęcka 1987, 1999; Nęcka, Orzechowski, Szymura 2017).

Psychologowie stosują też inny termin, który traktowany jest jako synonim kreatywności: jest to inwencja, „proces twórczy angażujący indywidualny, grupowy i organizacyjny potencjał kreatywności" (Kożusznik 2010a, s. 1; 2010b).

Pojęcie kreatywności jako działalności człowieka jest wieloznaczne, niemniej w literaturze przedmiotu można wyróżnić koncepcje, w których kładzie się nacisk na cechy psychiczne jednostki twórczej jako czynniki wywierające wpływ na jej aktywność twórczą (Sternberg, Lubbat za: Ulatowska 2013; Nęcka, Strzałecki, Trzebiński za: Tokarz 2010) oraz podejścia interakcyjne (np. Sawyer 2006; Simonton, Csíkszentmihályi, Kocowski za: Tokarz 2010), uwzględniające doniosłą rolę czynników społecznych i środowiskowych. Zgodnie z pierwszym podejściem twórczość definiuje się jako "działalność człowieka przynoszącą rezultaty obiektywne lub/i systematycznie wartościowe, we wszystkich dziedzinach życia, zwłaszcza w nauce sztuce i kulturze" (Tokarz 1998, s. 60-70). Drugie z wymienionych ujęć w większym stopniu koncentruje się na rezultatach i na przedmiocie ludzkiej działalności. W tym rozumieniu za "twórczy” można uznać nowatorski produkt, który osiąga taki poziom w opinii społecznej (Sawyer 2006, s. 27 za: Alcenar 2012, s. 88).

Csíkszentmihályi zwraca uwagę na to, że kreatywność jest swoistym odbiciem systemu społecznego, który dokonuje oceny jednostek. Tak więc, społeczne i kulturowe warunki w interakcji z indywidualnymi możliwościami decydują o tym, „że obiekty i zachowania są określone mianem twórczych" (Csíkszentmihályi 1994 za: Alcenar 2012, s. 88).

\section{Kreatywność na poziomie mechanizmów psychologicznych}

Z przeprowadzonych dotychczas badań wynika, że poziom inteligencji jest czynnikiem determinującym kreatywne myślenie. Ponadto (zgodnie z wynikami badania IPAR) osoby twórcze cechują się otwartością na wieloznaczność, a także niezależnością. 
Za znaczący czynnik w psychologii twórczości uważa się również Witkinowską "niezależność od pola", ujmowaną jako styl poznawczy. Twórca tej koncepcji potraktował ją jako właściwość, dyspozycję psychologiczną pozwalającą jednostce uniezależnić się od wyuczonych, narzuconych schematów myślenia i dzięki nowemu całościowemu spojrzeniu na problem znaleźć zupełnie inną konfigurację elementów, które mają związek z wytworzeniem nowej jakości. Według Witkina ludzie niezależni od pola wykazują większą skłonność do kreatywnego, oryginalnego ujmowania elementów rzeczywistości (za: Lewicki 1969; Trzebiński 1975). Posiadając wspomnianą właściwość, można łatwiej doznać zjawiska znanego w psychologii twórczości jako "insight". Polega ono na nowym, spontanicznym ujęciu elementów zewnętrznego i wewnętrznego pola spostrzeżeniowego (jego mentalnej reprezentacji). To nowe spojrzenie nagle staje się spójne i pozwala rozwikłać wiele - dotychczas nie do końca jasnych - zależności. Mimo że rozwój tej właściwości nie stał się zasadniczym przedmiotem zainteresowania autora, nie wykluczył on zasadności podejmowania działań w kierunku doskonalenia tej cechy (a być może i kompetencji). Czynnik ten zdaniem autorki można wiązać z "wewnętrzną sterownością" (za: Krasowicz, Kurzyp-Wojnarowska 1990).

Kolejną właściwością dość szeroko rozważaną w literaturze przedmiotu jest refleksyjność, ujmowana jako zdolność zachowania dystansu emocjonalnego wobec otaczających zjawisk, zdarzeń, własnych emocji i zaangażowania w określoną działalność (Brav i in. 2009). Kształtowanie refleksyjności przekłada się w programach szkolenia na ćwiczenie narracji jako metody rozwijającej autorefleksję, a także zdolność definiowania i oceny własnego stanowiska wobec prezentowanych treści.

W budowaniu poczucia sprawczości istotną rolę odgrywa także struktura zwana systemem „Ja". Jest on określany jako "dynamiczny i uporządkowany układ myśli, uczuć i motywów odnoszących się do własnych relacji społecznych i osobistego stosunku do świata" (Holye 2006 za: Strelau, Doliński 2010, s. 738). Obejmuje on następujące elementy (Heatherton $i$ in. 2007):

$\rightarrow$ Ja poznawcze - samowiedzę,

$\rightarrow$ Ja wartościujące - samoocenę,

$\rightarrow$ Ja wykonawcze - autoregulację.

Dwa pierwsze elementy charakteryzują strukturę Ja, ostatni odnosi się do Ja ujmowanego jako proces. 
Czynnikiem warunkującym kreatywne myślenie okazały się jeszcze inne aspekty Ja, określające stosunek człowieka do wymogów otoczenia w kontekście własnych, świadomych motywów działania, jednak umożliwiających nabycie przez niego dystansu do własnych, uzależniających go potrzeb. Kazimierz Obuchowski stosunkowo wcześnie wyodrębnił Ja przedmiotowe oraz Ja intencjonalne (podmiotowe). Zdaniem tego autora Ja przedmiotowe jest "fenomenologicznie wtórne wobec Ja podmiotowego" (Obuchowski 2003, s. 162-177) i funkcjonuje jako pozwalające się człowiekowi zdystansować od jego bezpośrednich potrzeb i pragnień. Pozwala nawet nie poddawać się oddziaływaniu czynników zewnętrznych w obszarze działania, w którym funkcjonuje (np. wynikających z uwarunkowań kulturowych - przyp. autora). Ja przedmiotowe, stanowiące o treści i strukturze systemu Ja, poddane jest kontroli Ja intencjonalnego. W ten sposób możemy mówić o autonomii jednostki (Obuchowski 2000, s. 320.) dotyczącej własnych aspiracji, wizji własnej kariery czy sukcesu zawodowego niezależnie od wieku, który w tym przypadku jest czynnikiem zewnętrznym.

Ja podmiotowe obejmuje dwa procesy: autorefleksję, jako zdolność do samopoznania i ujmowania siebie w relacji do otoczenia, oraz samoregulację, jako funkcję wykonawczą, polegającą na umiejętności sprawowania kontroli nad własnymi myślami, uczuciami i działaniami (McDonald 2007 za: Oleś, Drat-Ruszczak 2010, s. 712).

Podobnie jak dzieje się w przypadku poznawania świata, wiedzę o sobie ujmujemy $w$ formę określonych schematów Ja, np. przeświadczenia o własnej niezależności. Schematy te stają się elementem standardów, które z kolei wchodzą w skład Ja realnego, idealnego czy powinnościowego.

Istnienie Ja idealnego, zgodnie z koncepcją Charlesa Carveya (2001), sprawia, że u człowieka pojawia się system dążeń motywujących do osiągania swoich ideałów w poszczególnych obszarach życia. Z tego też względu rozbieżność między Ja realnym a Ja idealnym utożsamianym z Ja powinnościowym (wykreowanym w procesie socjalizacji) wywołuje zróżnicowane stany emocjonalne ${ }^{3}$. W przypadku realizacji standardów

Problematykę tę w sposób komunikatywny wyjaśnia teoria ukierunkowań Ja, zaproponowana przez E. Tory Higginsa (Higgins 1987, 1996), w myśl założeń której duża rozbieżność między Ja idealnym a Ja realnym generuje stany emocjonalne takie jak depresja, smutek i przygnębienie, natomiast dużej rozbieżności między Ja realnym a Ja powinnościowym towarzyszy lęk strach przed karą, poczucie winy. 
Ja idealnego wzrasta poczucie satysfakcji, spełniania się, a nawet radości, jakże istotne w przypadku osób dojrzałych.

W niniejszym opracowaniu kreatywność utożsamiana jest ze zdolnością do wprowadzania nowych rozwiązań, odkrywania nowych, skutecznych metod, w wyniku pojawienia się w umysłach ludzi nowych oryginalnych pomysłów, które w konsekwencji przyczyniają się do podwyższania jakości życia człowieka.

\section{Ludzie w wieku dojrzałym}

Starzenie się jako proces i starość jako kulturowo kształtowane zjawisko niosą ze sobą pewnego rodzaju opresyjność. Nie tylko dlatego, że starość to ostatni okres w życiu, który kończy się śmiercią, ale też z powodu zmian wartości, które dokonują się w biografii seniorów, oraz struktury życia społecznego i tempa zachodzących w nim przeobrażeń, mających strategiczne znaczenie dla jednostkowego funkcjonowania ludzi starych i dla ich tożsamości (Chabior 2017, s. 7-8). Starość określa się jako okres w życiu organizmu nieuchronnie występujący po okresie dojrzałości i cechujący się istotnymi zmianami w narządach i tkankach.

Starość współtowarzyszy niemal wszystkim procesom społecznym. Nie zawsze jednak stanowi etap wypełniony radością, spokojem, poczuciem satysfakcji. Wszechobecny rozwój technologiczny nie tylko zagwarantował pozytywne zmiany, lecz także wygenerował nowe zagrożenia i problemy. Mimo że osoby starsze stanowią grupę bardzo zróżnicowaną ze względu na sytuację osobistą, rodzinną, zawodową, zdrowotną i materialną, społeczeństwo zdaje się o tym zapominać, budując niewłaściwe przekonanie na temat seniorów i starości (Dubas, Muszyński 2016, s. 115).

Jakość życia w okresie starości jest wyznaczana przez wiele powiązanych wzajemnie czynników, wśród których ważne miejsce przypisuje się zdrowiu, aktywnej postawie wobec życia. Początkowo pojęcie "jakość życia" bazowało na ekonomicznym wymiarze egzystencji człowieka. Zakładano, że jest to zależność liniowa o kierunku dodatnim, wraz z wyższym dochodem i materialnym poziomem życia osiąga się wyższą jego jakość. Współcześnie włącza się w zakres tego pojęcia także aspekt psychologiczny i społeczny, w tym dobrą pozycję społeczną, poczucie stabilizacji życiowej, podejście do życia, umiejętność rozwiązywania problemów. Szczególne znaczenie przypisuje się zdrowiu jako podstawie całościowego funkcjonowania człowieka. Pojęcie 
"jakość życia" jest konstruktem wielowymiarowym, kształtowanym przez czynniki zarówno obiektywne, jak i subiektywne. Postrzegana subiektywnie jakość życia odzwierciedla poziom zadowolenia z życia w jego zdrowotnym, materialnym i duchowym wymiarze. Zgodnie z koncepcją WHO jakość życia to postrzegana przez jednostkę pozycja w życiu, w kontekście kultury i systemu wartości, w których żyje, oraz w zgodności z własnymi celami, oczekiwaniami, standardami i obawami (Halicka, Halicki, Kramkowska 2016, s. 325-327). Definicja ta opiera się na wcześniejszej definicji zdrowia, zgodnie z którą jest ono stanem fizycznego, psychicznego i społecznego dobrostanu, a nie tylko brakiem choroby czy ułomności (Definicja...).

Definicja ta stanowi podstawę do wykreowania nowej koncepcji medycyny, w której naukę tę czyni się odpowiedzialną nie tylko za przedłużenie biologicznego życia człowieka, ale również za usprawnienie go i uczynienie bardziej aktywnym.

Istnieje jednak wiele definicji jakości życia. Jest to pojęcie wielowymiarowe zmieniające się w czasie, definiowane nieco odmiennie na gruncie różnych nauk. W koncepcjach filozoficznych jakość życia utożsamiana jest $z$ dobrostanem (well-being), określanym jako różnica między "sumą wszystkich rodzajów przyjemności" a "sumą wszystkich rodzajów cierpień", jakich człowiek doświadcza w określonym przedziale życia.

Jakość życia bywa utożsamiana z dobrostanem, satysfakcją, szczęściem, dobrym życiem. Może być zaś mierzona stopniem, w jakim ludzie cieszą się życiem, wyrażają radość i satysfakcję z niego.

Jakość życia próbuje się poszerzyć w ostatnim czasie o wymiar duchowy, obejmujący wiarę religijną i przekonania światopoglądowe. W ocenie jakości życia istotną rolę odgrywają zasoby psychospołeczne, zarówno zdobyte we wcześniejszych okresach, jak i aktualne zasady i sieci wsparcia. Wcześniej koncepcja jakości życia w odniesieniu do seniorów opierała się na modelu patologii i zależności, koncentrowała się na pomiarze obniżonej wraz z wiekiem sprawności fizycznej, narządów zmysłów oraz na ograniczeniach w czynnościach. Obecna koncepcja jakości życia uwarunkowana stanem zdrowia jest ukierunkowana na pozytywne aspekty wskazujące na możliwość samodzielnego funkcjonowania osoby dojrzałej również w sytuacji, kiedy doświadcza ona niepełnosprawności czy przewlekłej choroby. Te możliwości funkcjonowania zależą od wielu czynników, od zasobów materialnych i sieci 
społecznych zbudowanych w toku całego dotychczasowego życia oraz ogólnego poczucia satysfakcji życiowej. Na gruncie nauk medycznych oznaczało to przyjęcie szerszej perspektywy wykraczającej poza tradycyjne koncepcje zdrowia (Halicka, Halicki, Kramkowska 2016, s. 325-327).

W aktualnych koncepcjach jakości życia uwzględnienie roli realizacji własnych pasji, wcześniej rozwiniętych zainteresowań wśród osób dojrzałych jako niezbędnych przesłanek kreatywnego nastawienia do życia nabiera szczególnego znaczenia. Chodzi o możliwość korzystania z rezerwuaru własnych zasobów, niezależnie od ograniczeń fizjologicznych, które pojawiają się w zróżnicowanym nasileniu, motywujących do dalszej aktywności i nadających sens własnemu życiu.

\section{Kreatywne myślenie u osób dojrzałych}

Jest prawdą oczywistą, że kreatywne myślenie współwystępuje z inteligencją ogólną, choć nie jest z nią tożsame. Jeśli niezależnie od istniejących kontrowersji za myślenie kreatywne uznajemy działania z jednej strony nowatorskie, z drugiej zaś użyteczne, badania przeprowadzane za pomocą testów kreatywności wykazały, że ludzie dojrzali słabiej wypadają w badaniach dotyczących myślenia dywergencyjnego (Stuart-Hamilton 2006, s. 78). Sytuacja ta zdaniem autora może być konsekwencją pewnego niewielkiego "ubożenia zdolności intelektualnych". Jednak zaistniała rozbieżność występuje, jeśli dokonuje się porównania osób młodszych ze starszymi, o tym samym poziomie intelektualnym i niezbyt wysokim wykształceniu (Alpaugh, Birren 1977; Mc Crae, Arenberg, Costa 1987). Wśród osób, które całe życie pozostawały zaangażowane w określoną działalność, różnica ta może być zdecydowanie mniejsza, a nawet może nie występować wcale (Crosson, Robertson-Tchabo za: Stuart-Hamilton 2006, s. 78-79).

Do ciekawych wniosków doszła Jennifer Sasser-Coen (1993), deprecjonując myślenie dywergencyjne w myśleniu twórczym na rzecz osobistego doświadczenia, dzięki któremu osoba dojrzała generuje pomysły. Mimo to niezależnie od osiągniętych w badaniach rezultatów Dean Simonton (1990) i Jon Hendricks (1999) podali w wątpliwość zasadność badania osób starszych miarami psychometrycznymi jako trafnymi predykatorami kreatywności w "prawdziwym życiu”.

Istnieją też dowody, że zaangażowane twórcze działanie osób starszych jest czynnikiem podnoszącym ogólną samowiedzę i samoocenę, 
zwiększającym poczucie dobrostanu (Hickson, Housley 1997 za: Stuart-Hamilton 2006; Steuden 2012).

Ustosunkowując się do niezależności w myśleniu i uniezależnienia się od zewnętrznych nacisków, badacze utożsamiali je z mądrością ludzi dojrzałych.

Podobnie jak w przypadku innych omawianych pojęć, mimo że mądrość (istota pojęcia, jej pomiar) wzbudza kontrowersje, Paul Bales i Jacqui Smith (2008) używają określeń „roztropność" i „dalekowzroczność w dokonywaniu sądów" niezależnych od ocen zewnętrznych, prezentujących dystans w planowaniu przyszłości przez osoby dojrzałe.

Na niezależność w formułowaniu własnych sądów i opinii u osób dojrzałych zwracali uwagę Ursula Staudinger, David Lopez i Paul Baltes (1997) oraz Staudinger i in. (1998), a także Wilson (2013). Jest to w rozumieniu tych autorów znacząca cecha, która świadczy o osobowości i inteligencji osób starszych (w porównaniu do ludzi młodszych), chociaż nie jest z nimi tożsama.

Z kolei efektywna samoregulacja i przekonanie o własnej skuteczności osób dojrzałych zostały przez Chandlera i Hollidaya (1990) ujęte jako poczucie kompetencji i realna zdolność do skutecznego rozwiązywania problemów, w których ważną rolę odgrywa czysta logika, typowy atrybut okresu późnej dorosłości.

Inny wątek badań nad kreatywnością osób dojrzałych dotyczy analizy biografii twórców. Jednak jego rezultaty nie są jednoznaczne, nie pozwalają bowiem ani na odrzucenie tezy, że myślenie kreatywne nie występuje w wieku późnej dorosłości, ani też na jej potwierdzenie. Przykładowo przywołany już Simonton (1990) jest zdania, że osoba kreatywna w poszczególnych okresach swojego życia niezależnie od wieku tworzy tyle samo przeciętnych prac, co prac nieprzeciętnych. Pnina Ron (2007) z kolei optuje za tym, że dla większości ludzi kreatywne działanie kończy się przed osiągnięciem 60. roku życia. Przyczyną tej sytuacji jest ograniczenie i pogorszenie się sensoryki i wydolności fizycznej człowieka dojrzałego, a do twórczego działania wierny i rzetelny ogląd rzeczywistości wydaje się niezbędny. Przeciwstawny pogląd prezentuje Butler (1967 za: Bartkowiak, 2016, s. 94), odwołując się do kazusów twórców, np. Tyego, którego dzieła namalowane po 90. roku życia są uznawane za najbardziej wartościowe, czy Beethovena, który w późniejszym okresie życia stracił słuch a dla którego ten deficyt stał się źródłem dalszych inspiracji. 
Wyjaśnienie zaprezentowanych kontrowersji wydaje się równie złożone, co obarczone błędami oceny, zgodnie z przytoczoną wcześniej definicją twórczego działania. Chodzi o społeczny kontekst osiągnięć uznanych za twórcze (Holroyd i in. 2009). Może on okazać się czynnikiem kontrowersyjnym, ponieważ może obejmować nie tylko elementy działań nie tyle twórczych, ile związanych z administracyjnie pełnioną funkcją.

Reasumując, zmiany w poziomie kreatywności w ciągu życia mogą wynikać bardziej ze stylu życia, społecznych wymogów wykonywanego dotąd zawodu niż z procesu starzenia się jako cyklu postępujących zmian fizjologicznych.

\section{Możliwości stymulowania kreatywności osób dojrzałych}

Wśród możliwości stymulowania kreatywności można wyróżnić podejścia psychologiczne i systemowe.

Analizując podejścia psychologiczne, wyodrębniono podejście behawiorystyczne, humanistyczne, poznawcze oraz oparte na założeniach psychologii pozytywnej. W pierwszym z nich istotną rolę $w$ rozwiązywaniu problemów związanych z twórczym myśleniem odgrywa wspierające i inspirujące oddziaływanie środowiska. Kreatywność w tym rozumieniu pojawia się jako efekt działań zmierzających do przekształcania rzeczywistości na podstawie posiadanej wiedzy, nabytych kompetencji i wzbudzanej przez otoczenie motywacji do działania. Psychologia humanistyczna interpretuje człowieka jako podmiot autonomiczny, który obserwuje, przewiduje, planuje, wnioskuje i który-zgodnie z posiadaną wiedzą - przystosowuje się do świata, kształtuje go. W ramach koncepcji humanistycznej istotną rolę odgrywa omówiona już wcześniej refleksyjność (Brav i in. 2009). Kształtowanie refleksyjności prowadzącej do kreatywnego myślenia (Trzebińska 2008, s. 141) przekłada się w programach szkolenia pracowników na ćwiczenie narracji jako metody rozwijającej autorefleksję, a także zdolność zdefiniowania i oceny własnego stanowiska wobec prezentowanych treści.

Przedstawiciele koncepcji poznawczej dużą wagę przywiązują do twórczości człowieka. Mimo że w obrębie jej założeń człowiek jest jednocześnie układem wartościującym i samosterującym się, w myśl założeń tej koncepcji szczególnie istotną rolę odgrywają treningi twórczości, które na każdym etapie życia człowieka czynią ludzkie myślenie bardziej elastycznym i przyczyniają się do wykreowania sprzyjających myśleniu twórczemu określonych struktur poznawczych. Struktury te 
z kolei pozwalają człowiekowi na redukowanie rozbieżności między Ja realnym a Ja idealnym.

Psychologia pozytywna dużą wagę przykłada do działań zwiększających dobrostan człowieka. Jako wywodząca się z psychologii humanistycznej podkreśla rolę poczucia sensu w pracy zawodowej jako warunku zaangażowania i twórczej postawy. Stymulacja do twórczego rozwoju w myśl założeń psychologii pozytywnej powinna rozbudzać nadzieję wśród osób dojrzałych na dalsze satysfakcjonujące życie (por. Trzebińska 2008, s. 150).

Prezentowane podejścia do twórczego działania człowieka, nawiązujące do określonych koncepcji psychologicznych, oczywiście nie wyczerpują wszystkich aktualnie funkcjonujących koncepcji, stanowią raczej wprawkę powiązania określonej psychologicznej koncepcji człowieka z jego kreatywnością.

Podejście systemowe zakłada, że praca twórcza jako szansa na kontynuację aktywności zawodowej osób dojrzałych, wymagająca wykorzystania nowych technologii, w tym automatyzacji i robotyzacji czynności powtarzalnych, prowadzi do zmniejszenia liczby miejsc pracy i wzrostu bezrobocia, ale też generuje nowe, bardziej elastyczne stanowiska (Król 2006, s. 22-27). Stałe zatrudnienie staje się domeną branż wymagających najwyższych kwalifikacji. Zachodząca "dematerializacja pracy" (Marody, Giza-Poleszczuk 2004, s. 239-257), czyli jej łączenie z operowaniem abstraktami i ideami - zamiast bezpośredniego udziału ludzi w wydobywaniu i przetwarzaniu surowców czy wytwarzaniu dóbr i usług materialnych - w mniejszym stopniu wymaga wysiłku fizycznego.

Praca twórcza w znacznej mierze opiera się na wykorzystaniu technologii cyfrowych, realizacji zadań nieokreślonych, zmiennych i refleksyjnych oraz na samodzielności, kwestionowaniu norm, tradycji i przepisów, a także kończy się niestandardowymi efektami (Schulz 1990, s. 155-156; Filiciak, Tarkowski 2010, s. 81-82). Wychodząc z takiego założenia, można uznać, że zachodzące w gospodarce, technologii i ekonomii zmiany sprzyjają twórczemu zaangażowaniu seniorów, w szczególności dysponujących użytecznymi zasobami, tzn. wiedzą niekonwencjonalną i oryginalnością, które stają się kluczowym zasobem pracowników. Posiadanie wiedzy jako istotnego zasobu pozwala na dłuższe pozostawanie zatrudnionym w pracy dzięki postrzeganiu jej w kategoriach rozwoju osobowości czy samorealizacji (por. Schulz 1990, s. 163-164; Marody, Lewicki 2010, s. 125; Jung 2009). 
W krajach wysokorozwiniętych praca twórcza uzasadnia próby utrzymywania osób dojrzałych jak najdłużej na rynku pracy, by ograniczyć obciążenia w systemach emerytalnych. Relacje między pracą a czasem wolnym seniorów pozwalają przypuszczać, że kreatywność może służyć łagodzeniu niekorzystnych skutków przejścia na emeryturę, ograniczaniu negatywnych stereotypów dotyczących starości oraz poszukiwaniu nowych ról społecznych dla seniorów.

W tym kontekście zdaniem Andrzeja Klimczuka (2013) możliwe jest podjęcie próby stworzenia podziału na klasę kreatywną i usługową. W pierwszym przypadku mielibyśmy do czynienia z seniorami kreatywnymi podejmującymi aktywność twórczą na rozmaitych polach: kultury, sztuki i nauki oraz przyjmującymi role animatorów, artystów i badaczy (za: Leszczyńska-Rejchert 2007, s. 205; Wawrzyniak 2010, s. 19-20; Dzięgielewska 2006a, s. 163-164). Działania te mogą prowadzić do poprawy stanu zdrowia, zapominania o wadach starości oraz do poszukiwania gerontechnologii ułatwiających życie. Osoby te będą przypuszczalnie częściej odmładzać się, podważać istnienie wieku emerytalnego, kontynuować aktywność zawodową, rozpoczynać nową karierę lub zakładać własne przedsiębiorstwa (Giddens 2009, s. 92, 170-176). $Z$ drugiej strony "seniorzy usługowi" reprezentowaliby zbiór osób, które na ostatnim etapie życia w mniejszym lub większym stopniu pomagają innym w osiąganiu ich celów. Mieściłyby się tu osoby wspomagające emeryturami swoje rodziny, wspólnoty religijne i grupy samopomocowe. Jednakże badania sondażowe przeprowadzone przez autorkę wśród 257 studentów z trzech uczelni kierunków humanistycznych i społecznych $w$ trzech dużych miastach w Polsce dotyczące prospołecznego nastawienia i chęci niesienia pomocy przez ich babcie i dziadków w $97 \%$ wykazały prospołeczne nastawienie wyłącznie w odniesieniu do własnej rodziny.

W każdym przypadku wspomaganie aktywnej postawy osób dojrzałych wymaga tworzenia odpowiednich warunków, rozwiązań systemowych dla seniorów, uwzględniających specyfikę wieku dojrzałego (wyraźne napisy ulic, telefony komórkowe z powiększoną klawiaturą), sieć usług ułatwiających codzienne funkcjonowanie (np. zakupy z wniesieniem do domu, windy w większości miejsc zamieszkania, bardziej dostępna opieka zdrowotna itp.). Wówczas energię seniorów będzie można spożytkować na kreatywne myślenie czy też aktywne uczestnictwo w życiu społecznym, dłuższe zatrudnienie, świadomą 
organizację czasu wolnego połączoną z uczestnictwem w szeroko pojmowanej kulturze.

\section{Zamiast zakończenia}

Przeprowadzone rozważania wskazały na złożoność omawianej problematyki: zróżnicowanie w obrębie samego rozumienia pojęcia i wielość uwarunkowań działania kreatywnego. Jednocześnie jego systemowy charakter wymaga podjęcia licznych działań, zarówno na poziomie indywidualnym, w odniesieniu do systemu edukacji, pracy zawodowej, jak i w szerszym rozumieniu, odnoszącym się do uwarunkowań systemowych: społeczno-ekonomicznych.

Aplikacyjny charakter wniosków płynących z rozważań o kreatywności wymaga uprzedniego analitycznego podejścia do problemu, poznania specyfiki ich funkcjonowania i rozpoznania mechanizmów regulacji zachowania osób w wieku senioralnym. 


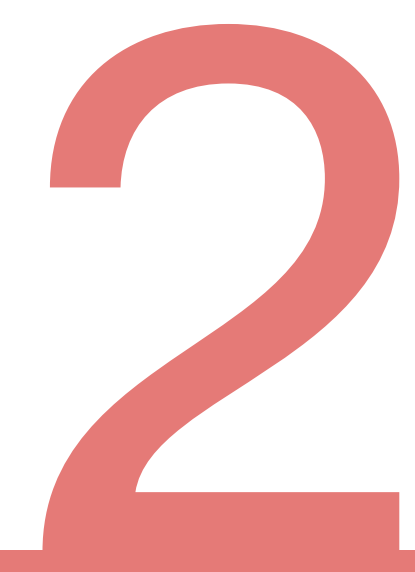


Rola kreatywności w systemach edukacji 


\title{
Przygotowanie i ocenianie zadań ksztalcących kreatywność i myślenie projektowe uczniów
}

\author{
Adam Kalbarczyk
}

Celem rozdziału jest przedstawienie typologii zadań kształcących kreatywność u uczniów oraz kryteriów ich oceniania. Założenia teoretyczne wykorzystane w pracy obejmują następujące twierdzenia:

$\rightarrow$ Kształcenie kreatywności jest ważnym zadaniem współczesnej edukacji szkolnej i powinno obejmować wszystkich uczniów.

$\rightarrow$ Zadania kształcące kreatywność powinny być grupowymi zadaniami projektowymi.

$\rightarrow$ Tematy zadań powinny być atrakcyjne dla uczniów.

Przedstawiona w rozdziale propozycja typów zadań odwołuje się do naturalnych dla ludzi procesów wprowadzania oryginalnych i twórczych nowości do systemu językowego (derywacje, neologizmy, zapożyczenia, metafory, kompozycje, inwencje słowne). Trzy proponowane kryteria oceny tego rodzaju zadań obejmują: oryginalność, trafność i elegancję rozwiązań.

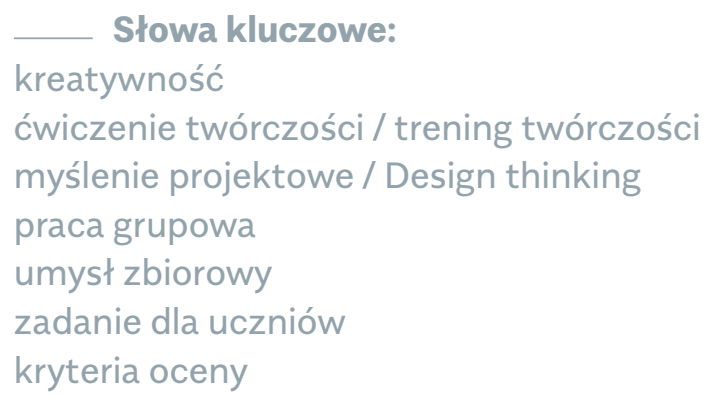




\title{
Preparation and assessment of tasks that form students creativity and design thinking
}

\author{
Adam Kalbarczyk
}

The aim of this chapter is to present a typology of students tasks that form creativity and to list criteria of their assessment. The work is based on theoretical assumptions listed below:

$\rightarrow$ Creativity forming is an important aim of contemporary school education and should embrace all students.

$\rightarrow$ Tasks that form creativity should be group project tasks.

$\rightarrow$ The topic of the tasks should be attractive for students.

The proposal included in this work connects with natural human processes of introducing new and original solutions to the language system (derivations, neologisms, loan-words, metaphors, compositions, word inventions).

Three proposed criteria of assessment of creativity tasks embrace: originality, accuracy and elegance of solutions.

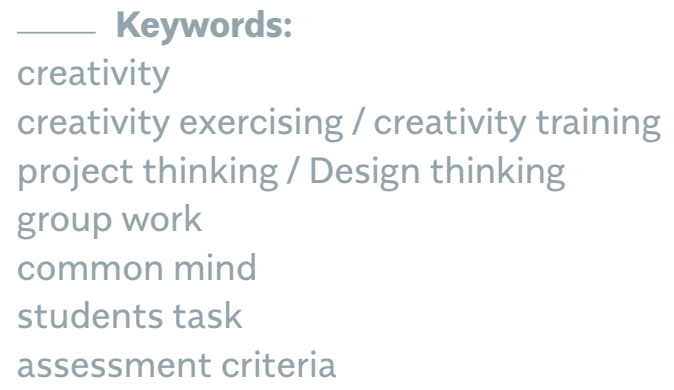




\section{Wprowadzenie}

Niniejszy rozdział przedstawia typy zadań możliwych do wykorzystania w praktyce szkolnej w celu kształcenia kreatywności u uczniów oraz propozycje kryteriów ich oceny. U podstaw tego opracowania leży przekonanie, że kreatywność warto i można kształcić w szkole. Warto, dlatego że przez bardzo wielu współczesnych ekspertów edukacyjnych zaliczana jest ona do kluczowych "kompetencji przyszłości” (Robinson 2016; Zhao 2012). Wymienia się ją także wśród kompetencji kluczowych w Zaleceniu Rady Unii Europejskiej z dnia 22 maja 2018 r. w sprawie kompetencji kluczowych w procesie uczenia się przez całe życie. Rada UE zaleca tam m.in. „pielęgnowanie kompetencji w zakresie przedsiębiorczości, kreatywności i zmysłu inicjatywy, szczególnie wśród młodych ludzi" (Zalecenie Rady UE 2018). Można zaś ją rozwijać i pielęgnować zgodnie z przekonaniem, że ludzkie zdolności twórcze nie dotyczą tylko wybranych, wybitnych jednostek, ale mają charakter powszechny i mogą być kształcone u każdej osoby.

Kształcenie kreatywności w szkole stało się jej niedyskutowanym zadaniem od czasu, gdy do powszechnej świadomości dotarło przekonanie, że tradycyjny model edukacji nie tylko nie służy rozwijaniu kreatywności u uczniów, ale także wpływa na obniżenie twórczego potencjału dzieci. Najbardziej znanym raportem w tym zakresie było opracowanie Kena Robinsona, którego badania z lat 80. ubiegłego wieku wywołały wstrząs w Wielkiej Brytanii (Robinson 1982). W wielu swoich pracach badacz ten przekonuje dziś nie tylko o wartości, ale także o niezbędnej potrzebie kształcenia kreatywności w szkołach (Robinson 2010, 2016).

Podobnie jest również po drugiej stronie oceanu. Jeden z najbardziej wpływowych amerykańskich ekspertów edukacyjnych Yong Zhao mówi o konieczności przygotowania uczniów do pełnienia roli samodzielnych przedsiębiorców, umiejących twórczo rozwiązywać problemy, w odróżnieniu od dotychczasowej praktyki kształcenia pracowników potrafiących przede wszystkim doskonale wykonywać zadania odtwórcze (Kalbarczyk 2015; Richardson i in. 2017; Zhao 2012).

\section{Przesłanki kształcenia kreatywności}

Według Edwarda Nęcki istnieją trzy przesłanki, by twierdzić, że twórczość można ćwiczyć (trenować). Są nimi: humanistyczna wizja człowieka, postrzeganego jako podmiot twórczy; dostrzeganie przejawów 
twórczości „potencjalnej” w zwyczajnych działaniach ludzi (zwłaszcza dzieci) oraz zwyczajność operacji intelektualnych składających się na akty twórcze (Nęcka i in. 2012, s. 10).

Kreatywność jest w psychologii rozumiana jako właściwość ludzi, procesów i produktów (Nęcka 2003, s. 13). Wśród licznych definicji tej cechy badacze wskazują na powtarzalność jej dwu elementów konstytutywnych: nowości i wartościowości. Kreatywni ludzie zatem to ci, którzy są zdolni do wytwarzania nowych i wartościowych produktów, rozumianych szeroko, nie tylko w sensie materialnym (Nęcka 2003, s. 13, 19; Szmidt 2007, s. 53). Procesy twórcze to zaś takie procesy psychiczne, które prowadzą do wytworzenia nowych i wartościowych idei, produktów w szerokim sensie (Nęcka 2003, s. 35). Celem kształcenia kreatywności w szkole byłoby więc kształcenie zdolności u uczniów do wytwarzania nowych i wartościowych produktów. Zdolności te według Zhao składają się z trzech elementów: 1) zdolności poznawczych, pozwalających na odkrywcze powiązanie istniejących zjawisk i przedmiotów oraz tworzenie z nich nowych rezultatów/produktów; 2) odwagi tworzenia, łączącej postawę otwartości umysłowej z gotowością pokonywania wyzwań, trudności i niepewności - emocjonalnego ryzyka w celu odkrywania nowych rozwiązań; 3) nastawienia na społeczną wartość podejmowanych działań (Richardson i in. 2017).

Jeżeli kreatywność jest pewnym rodzajem ludzkich zdolności, które ujawniają się w procesach prowadzących do tworzenia nowych i wartościowych produktów, to - jak każda zdolność - podlega ona kształceniu. Jego podstawą jest działanie. Referując raport Robinsona (Robinson 1999), Krzysztof Szmidt pisał: „Twórczość ma swoje źródło w wielu zwyczajnych zdolnościach i umiejętnościach, a nie w odosobnionym talencie. $Z$ tego względu w rozwijaniu twórczości pomocne jest pobudzanie i wspieranie prostych uzdolnień wrażliwości i sprawności. [...] zdolności twórcze są najlepiej wspierane w procesie stawania się twórczym. Dlatego właśnie uczenie się przez działanie może być podstawą nauczania twórczości, a przebiega ono najlepiej i może być właściwie wzbogacane dzięki pracy pod kierunkiem mentorów i mistrzów" (Szmidt 2007, s. 22).

\section{Techniki i metody kształcenia kreatywności}

Badacze kreatywności opisują różne techniki, metody i strategie kształcenia kreatywności. Edward Nęcka proponuje metodę twór- 
czego rozwiązywania problemów, która składa się z działań w dwu przestrzeniach: problemu i rozwiązań. Każdy z nich dzieli się na trzy fazy postępowania z problemem i jego rozwiązaniem (Nęcka 1994). Witold Dobrołowicz opisuje cztery rodzaje treningu twórczości: instrumentalny, stosowania metod inwentycznych, osobowościowy i abarietyczny, czyli służący przełamywaniu barier psychologicznych (Szmidt 2005, s. 58-66). Ellis P. Torrance wyróżnia sześć typów tego treningu, w tym trening ćwiczący umiejętność rozwiązywania problemów i rozwijający twórcze pisanie. Jane Piirto wymienia kilkanaście technik treningu twórczości, m.in. trening twórczego rozwiązywania problemów. Opis tych treningów można znaleźć w opracowaniu Krzysztofa Szmidta (Szmidt 2007, s. 299-300). Cechą wspólną tych ujęć są zadania kształcące twórcze rozwiązywanie problemów. Zadania kształcące kreatywność są więc elementem wielu (jeśli nie wszystkich) programów „wychowania do twórczości". Ich przegląd można znaleźć także u Szmidta (Szmidt 2007, s. 308 i n.). Są to m.in.: CoRT (Cognitive Research Trust) Edwarda de Bono, Future Problem Solving Ellisa P. Torrance'a i Pansy Torrance, Creative Problem Solving Scotta Isaksena, Donalda Treffingera i Briana Dorvala czy CIFS (Creative Intelligence for School) Roberta Sternberga.

Problemy (zadania) służące najskuteczniejszemu kształceniu kreatywności według Torrance'a, zastosowane w programie realizującym zasady jego Inkubacyjnego Modelu Nauczania, to zadania, w których znalezienie najlepszych rozwiązań jest poprzedzone ustaleniem kryteriów sukcesu tych rozwiązań, podjęciem decyzji co do ich wyboru oraz których rozwiązanie obejmuje proces ulepszania i ewaluacji oraz praktycznego zastosowania, czyli wdrożenia innowacji (Szmidt 2007, s. 313). Innowacja jest tu rozumiana jako „proces wdrażania, zastosowania, przyswojenia nowości" czy też, jak ujmuje to Michael A. West, „przekładania nowych idei na język praktyczny” (Szmidt 2007, s. 54, 56).

Wskazuje to bardzo wyraźnie na związek tego typu zadań z myśleniem projektowym. Jedną z najbardziej znanych metod tworzenia nowych produktów i wdrażania innowacji jest metoda Design thinking opracowana przez Tima Browna. Polega ona na tworzeniu nowych, oryginalnych produktów, procesów lub rozwiązywaniu problemów, ale przez osoby, jak podkreśla twórca tej metody, niezwiązane profesjonalnie z projektowaniem i zastosowanie jej do szerszego zakresu rozwiązań niż tylko projektowanie w sensie ścisłym (Helman, Rosienkiewicz 2016). 


\section{Zasady myślenia projektowego}

Projektowanie według założeń tej metody: 1) jest czynnością społeczną; 2) wymaga eksperymentowania i uwzględnienia różnych punktów widzenia; 3) jest zwykle „przeprojektowywaniem” rozwiązań, które już istnieją; 4) wymaga wizualizacji i tworzenia prototypów (Helman, Rosienkiewicz 2016). Metoda ta stanowi zatem doskonałe źródło tworzenia zadań kształcących kreatywność uczniów. Jej zastosowanie daje możliwość kompleksowego kształcenia uczniowskiej kreatywności i wykorzystywania jej w życiu. W odróżnieniu od ćwiczeń rozwijających jakiś aspekt lub element kreatywności zadanie projektowe daje możliwość wieloaspektowego i wszechstronnego kształcenia kreatywności u uczniów.

Zgodnie z zasadami myślenia projektowego zadanie kształcące kreatywność u uczniów powinno cechować się następującymi właściwościami: 1) jego celem powinno być stworzenie nowego, wartościowego produktu; 2) powinno być zadaniem grupowym; 3) powinno pozwalać na aktywne poszukiwanie rozwiązań i eksperymentowanie z nimi; 4) powinno odwoływać się do wiedzy o istniejących rozwiązaniach; 5) powinno pozwalać na przetestowanie rozwiązań i ich ewaluację; 6) powinno być wykonywane metodycznie, zgodnie z określoną dla projektowania procedurą. Procedura ta obejmuje, tak jak w profesjonalnym projektowaniu, pięć etapów (Helman, Rosienkiewicz 2016):

$\rightarrow$ empatyzację,

$\rightarrow$ definiowanie problemu,

$\rightarrow$ generowanie pomysłów,

$\rightarrow$ budowanie prototypów,

$\rightarrow$ testowanie.

Wszystkie te etapy powinny być uwzględnione podczas wykonywania zadań projektowych przez uczniów.

\section{Forma grupowa w kształceniu kreatywności}

Zastosowanie formy grupowej do kształcenia kreatywności może na pierwszy rzut oka budzić wątpliwości. Największe dzieła artystyczne w historii ludzkości powstały przecież jako dzieła jednostek, a nie grup. Należy jednak zwrócić uwagę, że jednostki te nie potrzebowały żadnego kształcenia kreatywności i wykorzystały swój naturalny potencjał, który w wielu przypadkach służył także zbiorowości i był wykorzysty- 
wany później w działaniach grupowych. Z kolei stopień skomplikowania zadań, które stoją współcześnie przed ludzkością, wymaga pracy zespołowej i zbiorowego rozwiązywania problemów. Tak pracują dziś zespoły badawcze i twórcy nowych rozwiązań technologicznych. Co wciąż nie wyklucza działań tych wybitnych jednostek, które, zwłaszcza w dziedzinie sztuki, żadnego ćwiczenia kreatywności nie potrzebują.

O zaletach pracy grupowej w kształceniu kreatywności pisze m.in. Edward Nęcka. Opisując właściwości „umysłu zbiorowego", wskazuje na obserwowany przez wielu badaczy, występujący w przypadku zbiorowego działania twórczego, efekt synergii, w wyniku którego giętkość myślenia zbiorowego nie jest prostym zwielokrotnieniem zdolności twórczych członków grupy, a jego produktywność nie jest prostą sumą pomysłów każdego z jej członków (Góralski 1996, s. 16; Nęcka 1994, s. 83). Pisząc o szansach myślenia grupowego, wymienia Nęcka przewagi, jakie daje nad kreatywnością indywidualną różnorodność członków grupy, organizacja jej działań, tzw. efekt publiczności i wolny rynek idei (Nęcka 1994, s. 78-82). Nęcka opisuje także zagrożenia myślenia grupowego (Nęcka 1994, s. 74-78). Niektóre z nich nie dotyczą jednak uczniów (brak zagrożenia presji autorytetów, brak przywiązania uczniów do własności pomysłów czy małe ryzyko wystąpienia syndromu "ogłupienia grupowego", ponieważ uczniowie nie są ekspertami i nie działają pod nadmierną presją czasu). Oczywiście w pracy w grupie zawsze może wystąpić napięcie emocjonalne między członkami zespołu czy konflikt związany z ich zróżnicowaniem, a także zachowania autocentryczne. Nęcka zwraca zarazem uwagę, że kreatywne działania zespołowe powinny odbywać się w odpowiednich warunkach, które obejmują wzajemną sympatię członków grupy, ich zaciekawienie zadaniem, ludyczny nastrój jego wykonania, a także poczucie bezpieczeństwa i wolności (Nęcka 1994, s. 84).

Najbardziej wszechstronne zadania kształcące kreatywność wśród uczniów to zatem grupowe zadania projektowe. Warto zarazem zwrócić uwagę na autentyczność, praktyczność ich przedmiotu. Zadania budzące ciekawość, atrakcyjne dla uczniów nie powinny mieć charakteru problemów sztucznych, stworzonych tylko na użytek szkolny (Szmidt 2005, s. 96). Opisując zadania, które służą rozwojowi zdolności twórczych u uczniów, Szmidt wymienia cztery warunki, które zadania te powinny spełniać. Powinny one być: 1) otwarte, wzbudzające ciekawość uczniów, zachęcające do tworzenia wielu pomysłów na ich rozwiązanie; 2) różnorodne, angażujące "całą postawę twórczą" uczniów; 3) 
sprzyjające opanowaniu reguł użytecznych w rozwiązywaniu problemów; 4) autentyczne, związane z codziennym życiem uczniów i ich środowiskiem (Szmidt 2005, s. 97). Warto dodać, że jeżeli zadanie nie ma charakteru „życiowego", to może być atrakcyjne dla uczniów także wówczas, gdy będzie miało charakter zabawowy, ludyczny.

\section{Typy zadań kształcących kreatywność uczniów}

W klasyfikacji zadań kształcących kreatywność uczniów proponuję uwzględnić typy produktów będących ich celem i w związku z tym do jej przeprowadzenia zastosować podział procesów wykorzystywanych przez ludzi w działaniach słowotwórczych i semantycznych. Podobnie jak język stale rozwija się wskutek wykorzystania swych możliwości systemowych poprzez tworzenie nowych tworów słownych lub znaczeniowych, tak też zachodzą procesy twórcze. Przebiegają one w sposób podobny do działań w ramach systemu językowego, czyli analogicznie do tworzenia innowacji językowych - leksykalnych i semantycznych. Typy procesów twórczych, którym odpowiadają określone rodzaje zadań kształcących kreatywność u uczniów, obejmowałyby zatem:

$\rightarrow$ konstrukcję systemową (odpowiednik derywacji słowotwórczej - stworzenie nowego wyrazu z istniejącego lub istniejących wyrazów w ramach możliwości danego systemu),

$\rightarrow$ zapożyczenie (adaptacja wyrazu z innego systemu językowego na zasadzie analogii znaczeń),

$\rightarrow$ przeniesienie znaczeń (neosemantyzacja, metafora),

$\rightarrow$ złożenia (kompozycje, połączenia dotychczas istniejących elementów),

$\rightarrow$ wynalazki (odpowiednik innowacyjnego neologizmu pozasystemowego).

Przykładami zadań dla każdego z procesów byłyby:

$\rightarrow$ uczniowski wytwór z istniejących utworów (np. oryginalne uczniowskie przedstawienie teatralne stworzone na podstawie istniejących tekstów, rozwiązanie zadania matematycznego w nowy oryginalny sposób, samodzielne przeprowadzenie eksperymentu przyrodniczego przez uczniów),

$\rightarrow$ stworzenie produktu analogicznego (np. stworzenie oryginalnego, uczniowskiego języka obrazkowego do opisu fragmentu rzeczywistości), 
$\rightarrow$ wykorzystanie istniejących rozwiązań/produktów do nowych celów (np. uczniowski projekt recyclingowy),

$\rightarrow$ innowacyjne połączenie istniejących elementów (np. autorskie zilustrowanie istniejącego tekstu istniejącym utworem muzycznym; autorska wystawa plastyczna),

$\rightarrow$ nowy oryginalny utwór uczniowski (np. autorski tekst, wiersz, plakat, film, spektakl).

Przykładem zadania 1), które polegałoby na twórczym wykorzystaniu istniejących elementów, byłoby zadanie wykorzystywane przeze mnie w praktyce szkolnej nauczania filozofii w liceum:

$\rightarrow$ Cel projektu: wystawienie minispektaklu filozoficznego, w którym głównymi bohaterami będą filozofowie toczący ze sobą spór (rozmowę) na wybrany (poniżej) temat.

$\rightarrow$ Czas trwania spektaklu: maksymalnie 10 minut.

$\rightarrow$ Zespół projektowy: 4-5 uczniów, z których każdy odgrywa w spektaklu rolę któregoś z filozofów.

$\rightarrow$ Tematy i bohaterowie przedstawień (wybrani filozofowie mogą być zastąpieni przez innych, a nawet przez postacie fikcyjne):

- Czy świat istnieje? Osoby: Platon (Państwo - alegoria jaskini), Kartezjusz (Medytacje o pierwszej filozofii), David Hume (Traktat o naturze ludzkiej), George Berkeley (Traktat o zasadach ludzkiego poznania), Tadeusz Kotarbiński (O postawie reistycznej, czyli konkretystycznej).

- Czy można być czegokolwiek pewnym? Osoby: Sekstus Empiryk (Zarysy pyrrońskie), Platon (Fedon), Kartezjusz (Medytacje o pierwszej filozofii), Immanuel Kant (Prolegomena do wszelkiej przyszłej metafizyki), Kazimierz Ajdukiewicz (konwencjonalizm poznawczy).

- Czy Bóg istnieje? Osoby: Anzelm z Canterbury (tzw. ontologiczny dowód na istnienie Boga), Tomasz z Akwinu (Summa teologiczna - tzw. pięć dróg - "dowodów" na istnienie Boga), Kartezjusz (Medytacje o pierwszej filozofii), Jean-Paul Sartre (Egzystencjalizm jest humanizmem), Sam Harris (Koniec wiary). - Jak dobrze postępować? Osoby: Sokrates (Platon, Obrona Sokratesa), Arystoteles (Etyka nikomachejska), Augustyn Aureliusz (Wyznania), John Stuart Mill (Utylitaryzm), Peter Singer (Jeden świat. Etyka globalizacji). 
$\rightarrow$ Etapy zadania do wykonania:

- znalezienie tekstów filozoficznych (literackich) dotyczących określonej tematyki,

- wybór fragmentów odpowiadających tematyce,

- skonstruowanie scenariusza spektaklu z fragmentów wybranych tekstów; uwaga: całość nie może przekraczać 2 stron maszynopisu (czcionka Times New Roman 12, interlinia 1,5),

- opracowanie inscenizacji (ruch sceniczny, rekwizyty, kostiumy, ewentualnie: muzyka, światła, wykorzystanie multimediów itp.),

- podział ról (jeden uczeń - jeden filozof),

- przeprowadzenie prób spektaklu,

- nauczenie się ról,

- zaprezentowanie spektaklu.

Tekstów szukajcie w: B. Markiewicz, Filozofia dla szkoły średniej, w książkach podanych filozofów lub w internecie.

Przykładem zadania 2), polegającego na stworzeniu produktu analogicznego, może być zadanie zamieszczone w podręczniku do języka polskiego dla liceów i techników Oblicza epok (2019):

W kilkuosobowych grupach opracujcie projekt pisma obrazkowego, którego elementy posłużą do przełożenia poezji na mowę zrozumiałą dla dzieci dopiero rozpoczynających naukę czytania i pisania w języku polskim (np. uczniów pierwszej klasy szkoły podstawowej). Opracujcie ogólne założenia pisma, formę graficzną znaków - możecie się inspirować różnymi pismami obrazkowymi, hieroglifami egipskimi, pismem Majów, techniką rebusów itp. Następnie przygotujcie przekład fragmentu Ogrodu przedziwnego Leopolda Staffa:

W przedziwnym mieszkam ogrodzie,

Gdzie żyją kwiaty i dzieci

I gdzie po słońca zachodzie

Uśmiech nam z oczu świeci.

Wodotrysk bije tu dziwny,

Co śpiewa jak śmiech i łkanie;

Krzew nad nim rośnie oliwny

Cichy jak pojednanie. [...] 
Postępujcie zgodnie z podaną kolejnością działań, by skutecznie zrealizować swój projekt:

$\rightarrow$ Analiza założeń i danych: ustalenie, na czym ma polegać przekład wiersza, do kogo ma być adresowany, jakie cechy sprawią, że będzie zrozumiały dla odbiorców (dzieci) oraz analiza i interpretacja fragmentu w celu zrozumienia jego sensów.

$\rightarrow$ Analiza problemu: zdobycie informacji na temat pisma obrazkowego (czym się charakteryzuje, z czego się składa, jakie warunki musi spełniać) oraz poznanie istniejących systemów takiego pisma.

$\rightarrow$ Opracowanie koncepcji: zebranie pomysłów i stworzenie założeń projektowanego pisma (z jakich elementów powinno się składać, jak mają wyglądać znaki, czy będą proste i złożone, jakie będą zasady ich tworzenia, jak zapewnić pismu spójność i możliwość tworzenia nowych znaków itp.).

$\rightarrow$ Stworzenie prototypu pisma: opracowanie modelowych znaków spełniających założenia przyjęte w koncepcji.

$\rightarrow$ Przetestowanie prototypu: przełożenie fragmentu wiersza Staffa przy użyciu opracowanego pisma obrazkowego i sprawdzenie, czy dzieci rozumieją przekład.

$\rightarrow$ Stworzenie (opisanie) zasad pisma po wyciągnięciu wniosków z testów.

\section{ETAPY PRZYGOTOWANIA PROJEKTU}

analiza założeń (cel, odbiorcy, dane, zasoby)

analiza problemu (zdobycie wiedzy na temat dotychczasowych rozwiązań, odbiorców itp.)

koncepcja (zebranie pomysłów, wybór najlepszego)

prototyp (model wykonany według założeń koncepcji)

przetestowanie i ewaluacja prototypu (sprawdzenie, czy rozwiązanie realizuje cele)

stworzenie gotowego produktu realizującego cele projektu 
Przykładem zadania 3) byłoby zadanie techniczne, w ramach którego uczniowie mieliby zbudować jakiś nowy produkt z używanych elementów, np. tablicę z oznaczeniem swojej sali lekcyjnej z plastikowych i metalowych odpadków, albo zadanie gastronomiczne, np. polegające na przygotowaniu potrawy z tego, co aktualnie znajduje się w lodówce szkolnej pracowni.

Przykładem zadania 4) byłoby zadanie projektowe zamieszczone w cytowanym wyżej podręczniku do języka polskiego:

Przygotujcie wystawę Ludzie i bogowie w mitologii greckiej poświęconą konfliktom między bogami a ludźmi. Wykorzystajcie dzieła plastyczne, muzyczne, teatralne i filmowe.

\section{Ocenianie zadań kształcących kreatywność uczniów}

Ewaluacja tego rodzaju zadań powinna koncentrować się na ocenie jakości obiektywnych produktu, a nie (zgodnie z klasyfikacją Nęcki) - na kryteriach subiektywno-emocjonalnych i samym procesie twórczym (Nęcka 2003, s. 32-33). Kryteriami oceny powinny zatem być - zgodna ze skalą semantyczną dzieł twórczych Susan Besemer i Karen O'Quinn (Nęcka 2003, s. 29) oraz odpowiednia dla przyjętej wyżej definicji twórczego produktu:

$\rightarrow$ jakość rozwiązania - oryginalność, innowacyjność, nowość;

$\rightarrow$ celowość wykonania - trafność, użyteczność, adekwatność;

$\rightarrow$ styl rezultatu - elegancja, staranność wykonania (dotyczy głównie indywidualnych twórczych zadań typu 5, polegających na tworzeniu np. autorskiego tekstu przez uczniów).

\section{Podsumowanie}

W niniejszym rozdziale przedstawiono opis typów zadań kształcących kreatywność uczniów oraz propozycję ich oceny. Typologia zadań kształcących zdolności twórcze uczniów obejmuje pięć rodzajów tych zadań i została zbudowana analogicznie do klasyfikacji działań słowotwórczych i semantycznych, służących ludziom do tworzenia nowych słów, wyrażeń i konstrukcji znaczeniowych. Propozycja kryteriów oceny zadań kształcących zdolności twórcze obejmuje trzy obszary, zgodne z definicją kreatywnego produktu. Opis tych zadań i kryteriów ich oceny został poprzedzony przedstawieniem założeń, które pozwalają mówić zarówno o zadaniach kształcących kreatywność uczniów, jak 
i o ich ocenie. Założeniami tymi są: przekonanie o wartości i konieczności kształcenia kreatywności w szkole (rozumianej jako zdolność uczniów do tworzenia produktów nowych i wartościowych społecznie) oraz uznanie możliwości takiego kształcenia, obejmującego wszystkich uczniów, czego dowodzą liczne istniejące i opisane techniki i metody ćwiczenia kreatywności. Podstawowym założeniem dotyczącym formy wykonania zadań jest przekonanie o wartości pracy grupowej w kształceniu kreatywności oraz uznanie myślenia projektowego za wzór modelu działania twórczego. 



\title{
Rozwój kompetencji proinnowacyjnych u uczniów - przykład niemieckich szkół podstawowych i ponadpodstawowych
}

\author{
Piotr Trąpczyński
}

Głównym celem tego rozdziału jest analiza zagadnienia pedagogiki w zakresie przedsiębiorczości w Niemczech na poziomie szkolnictwa podstawowego i średniego oraz zidentyfikowanie dobrych praktyk $w$ rozwijaniu proinnowacyjnych kompetencji u uczniów. W rozdziale wykorzystano przegląd międzynarodowej literatury związanej z edukacją przedsiębiorczą, a następnie w szczególności źródła pierwotne dotyczące rozwiązań stosowanych w Niemczech. Przedstawiona analiza akcentuje znaczenie wzajemnego oddziaływania rozwiązań na różnych poziomach: poziom państwa (lub, w przypadku zdecentralizowanych systemów edukacyjnych, takich jak niemiecki, poziom regionalny), poziom inicjatywy szkolnej, a także indywidualny poziom nauczycieli odpowiedzialnych za wdrażanie metod nauczania przedsiębiorczości.

\section{__ Słowa kluczowe: \\ kompetencje proinnowacyjne \\ kreatywność \\ edukacja w zakresie przedsiębiorczości \\ szkolnictwo podstawowe i średnie \\ Niemcy}




\title{
Development of pro-innovative \\ competences among pupils - an example \\ of German primary and secondary schools
}

\author{
Piotr Trąpczyński
}

The main objective of this chapter is to analyse the case of entrepreneurial pedagogy in Germany at the level of primary and secondary education and to identify good practices in the development of pro-innovative competences of pupils. The chapter uses a review of literature on entrepreneurial education, and particularly primary sources related to the solutions implemented in Germany. The analysis highlights the relevance of an interplay of solutions at different levels: the level of the state (or, in the case of decentralised educational systems like the German one, at the regional level), the level of school initiative, as well as the individual level of educators who are in charge of implementing entrepreneurial teaching methods.

\section{Keywords: \\ pro-innovative competences \\ creativity \\ entrepreneurship education \\ primary and secondary education \\ Germany}




\section{Wprowadzenie}

Rozwój kompetencji proinnowacyjnych jest postrzegany jako jedno z najważniejszych wyzwań współczesnych systemów edukacyjnych i szerzej pojętego rozwoju społeczno-gospodarczego (Marques, Albuquerque 2012; Tasnim, Yahya 2013). W rzeczywistości edukacja z zakresu przedsiębiorczości kształtuje postawy i intencje przedsiębiorcze, a także zdolności innowacyjne młodego pokolenia (Wach 2015, 2013; Moreno, Wach 2014).

Choć edukacja w zakresie innowacyjności i szerzej pojętej przedsiębiorczości w światowej literaturze znajduje się obecnie u szczytu swej popularności, w Polsce jest to wciąż relatywnie nowy i zyskujący na znaczeniu temat, w coraz większym stopniu podejmowany przez naukowców różnych dyscyplin. W ostatniej dekadzie XX W. w literaturze przedmiotu toczyła się debata na temat tego, czy można nauczyć się przedsiębiorczości i innowacyjności (Wach 2016a, 2016b). Postawy przedsiębiorcze, w tym kreatywność w biznesie, to ważne atrybuty pożądane na rynku pracy, zatem edukacja uniwersytecka powinna wyposażyć absolwentów nie tylko w odpowiednią wiedzę i umiejętności, ale także w pożądane postawy przedsiębiorcze (Wach 2014a, 2014b). W tym duchu edukacja w zakresie przedsiębiorczości jest znacznie szersza niż sama edukacja biznesowa lub ekonomiczna.

Mimo że od dawna zwracano uwagę na istotne znaczenie edukacji akademickiej w kształtowaniu postaw przedsiębiorczych i zdolności proinnowacyjnych (Kwieciński, Młodzińska-Granek 2014; Wach 2016b, 2002), możliwości i ograniczenia wdrażania pedagogiki z zakresu zdolności innowacyjnych na poziomie edukacji szkolnej były analizowane w mniejszym stopniu. Ponieważ nie istnieje zgodność co do tego, czy przedsiębiorczość jest cechą wrodzoną, czy nabytą (Henry, Hill, Leitch 2005), zasadne wydaje się jak najwcześniejsze rozwinięcie postaw przedsiębiorczych, w szczególności kreatywności, tak potrzebnej we własnej działalności gospodarczej.

Niniejsze opracowanie przedstawia analizę zagadnienia prowadzenia edukacji na rzecz rozwoju kompetencji proinnowacyjnych w Niemczech na poziomie szkolnictwa podstawowego i średniego. Poświęcenie uwagi temu systemowi kształcenia wynika z konkretnych przesłanek. W grudniu 2016 r. Organizacja Współpracy Gospodarczej i Rozwoju (OECD) opublikowała raport Programme for Internatio- 
nal Student Assessment ${ }^{1}$ (PISA) - Program Międzynarodowej Oceny Umiejętności Uczniów za 2015 r. Zgodnie z tym raportem Niemcy należą do pierwszej dziesiątki krajów europejskich w badaniu wyników uczniów, ale nadal wykazują większe niż przeciętnie luki w osiągnięciach w niektórych dziedzinach (OECD 2016). Z przykładu Niemiec można zatem czerpać wiedzę nie tylko na temat dobrych praktyk dla rozwoju kompetencji proinnowacyjnych, ale także niedoskonałości związanych z wdrażaniem przyjętych rozwiązań systemowych i możliwych podejść do radzenia sobie z nimi.

W pierwszej części niniejszego rozdziału wyjaśniono pojęcie pedagogiki na rzecz przedsiębiorczości i dokonano przeglądu współczesnych koncepcji dydaktycznych, w szczególności nauczania zorientowanego na proces. Następnie przedstawiono przypadek niemiecki w celu przeanalizowania sposobu, w jaki można wdrożyć pedagogikę z zakresu rozwoju zdolności innowacyjnych i kreatywności na różnych, powiązanych ze sobą poziomach. W sekcji podsumowującej omówiono czynniki warunkujące powodzenie wdrożenia takiego podejścia.

\section{Przegląd literatury}

Innowacyjność jest uznawana za jeden z ważnych czynników wpływających na procesy rozwoju społeczno-gospodarczego (Daszkiewicz 2014; Wach 2016b). Celem systemu edukacji na wszystkich poziomach kształcenia powinno być przede wszystkim kształtowanie kompetencji proinnowacyjnych u młodzieży i studentów (Urbaniec 2014; Wach 2016b, 2013; Wach, Wojciechowski 2016). Ma to bowiem wpływ na ich późniejszy, pełny i satysfakcjonujący udział w życiu społeczno-gospodarczym (Wach 2015; Rachwał, Wach 2016). Znaczenie gospodarcze małych i średnich przedsiębiorstw spowodowało zmiany w procesach umiędzynarodowienia przedsiębiorstw i globalizacji gospodarki światowej, sprawiając, że przedsiębiorczość i kreatywność w biznesie należą do kluczowych czynników rozwoju gospodarczego. Należy to brać pod uwagę, projektując systemy kształcenia (Othman, Nasrudin 2016).

Tak zwana pedagogika przedsiębiorczości zajmuje się metodami nauczania, które zachęcają do kształtowania postaw przedsiębiorczych (Wach 2014a). W przeciwieństwie do konwencjonalnego podejścia do 
procesu uczenia się, które polega na uzyskiwaniu wiedzy od nauczyciela (Vermunt, Verschaffel 2000), koncepcja ta zakłada wzajemne przekazywanie sobie kompetencji i umiejętności. Wówczas rola ucznia przestaje być bierna, zastępuje ją bowiem uczenie się przez działanie (zob. rysunek 1). W przeciwieństwie do zdobywania wiedzy ze źródeł pisanych poprzez czytanie, metoda ta obejmuje edukację poprzez dialog i bezpośrednią wymianę informacji. Przedsiębiorcze ujęcie kształcenia się zakłada, zamiast uczenia się zgodnie z instrukcjami nauczyciela jako głównego eksperta, samodzielność ucznia i korzystanie z porad nauczyciela. Podobnie, w przeciwieństwie do uczenia się w dobrze zorganizowanym środowisku według z góry ustalonego harmonogramu, rozwijanie umiejętności w zakresie przedsiębiorczości powinno odbywać się w elastycznym, nieformalnym środowisku (Gibb 1993).

Rysunek 1. Koncepcja przedsiębiorczej edukacji
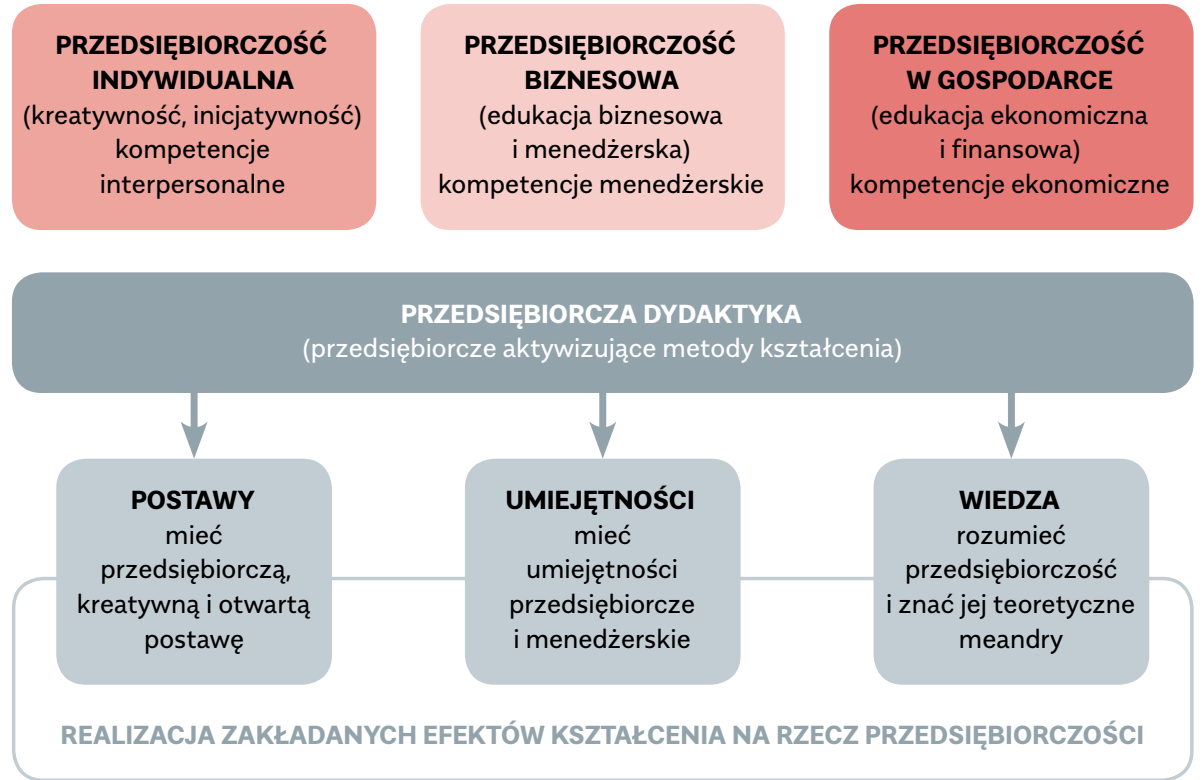

Źródło: Wach 2016a, s. 17.

Na zasadność koncepcji przedsiębiorczej edukacji wskazują wyniki istniejących badań. Wskazują one bowiem, że wiedza zdobyta przez 
jej aktywne rozwijanie jest bardziej dostępna i użyteczna niż ta przyjmowana biernie. W związku z tym w ostatnich latach coraz częściej zwracano uwagę na znaczenie podejścia do nauczania zorientowanego na proces (Abdous 2011; Brown 2010; Chen, Chen, Chen 2014; Vacek 2011). Wzajemne uznanie i dobre relacje nauczycieli i uczniów są podstawą dydaktyki zorientowanej na proces (Apelojg 2016).

Dydaktyka ukierunkowana na proces skupia się na procesie kształcenia się uczniów zgodnie ze wspólnie zdefiniowanymi celami uczenia się. W dydaktyce ukierunkowanej na proces chętnie podejmuje się wyzwania związane z ograniczeniami w przyswajaniu wiedzy i pomaga się wykorzystać je w rozwoju w procesie zdobywania wiedzy. Uczący się są zatem świadomi, że popełnianie błędów jest częścią procesu uczenia się. Są oni w dużym stopniu odpowiedzialni za osiąganie swoich celów indywidualnych i radzenie sobie $z$ wyzwaniami. $Z$ drugiej strony nauczyciele są $w$ tym procesie moderatorami, starają się nieustannie rozwijać własną koncepcję nauczania. Postrzeganie uczenia się jako procesu implikuje ciągłe kwestionowanie postępów uczniów i nauczycieli oraz wyznaczanie nowych celów rozwoju. Dydaktyka zorientowana na proces zapewnia zarazem wiele przestrzeni zarówno nauczycielom, jak i uczniom, aby mogli osiągać cele kształcenia.

Można przyjąć, że istnieją trzy podstawowe, wzajemnie powiązane formy uczenia się, którymi są świadome i nieświadome doświadczenie, imitacja oraz metoda prób i błędów (Apelojg 2016). Te trzy podstawowe tryby uczenia się dają odpowiednie wskazówki dotyczące procesu uczenia się. Po pierwsze, nauczyciele i uczniowie, oprócz świadomych doświadczeń edukacyjnych, mają również wiele doświadczeń nieświadomych. Po drugie, rola negatywnych doświadczeń edukacyjnych powinna być traktowana poważnie i stale uwzględniana w projektowaniu procesu kształcenia, ponieważ pomyłki stanowią wartościowe źródło wiedzy. Po trzecie, należy pamiętać, że uczniowie muszą jednocześnie doświadczyć sukcesu, aby mieć właściwą motywację do nauki (Zob. szerzej Łuczak-Trąpczyńska, Trąpczyński 2017).

\section{Studium przypadku: rozwój kompetencji proinnowacyjnych w Niemczech Kontekst badania}

W tabeli 1 przedstawiono listę kompetencji, które zostały zidentyfikowane na podstawie wywiadów z ekspertami uczestniczącymi w przepro- 
wadzeniu ekspertyzy "Szkoła dla innowatora” na zlecenie Ministerstwa Przedsiębiorczości i Technologii w 2017 r. oraz na podstawie kwerendy źródłowej. Należy zauważyć, że sama koncepcja "kompetencji proinnowacyjnych" nie jest powszechnie znana. Eksperci z Danii, Finlandii, Irlandii, Izraela, Japonii, Korei Południowej, Niemiec, USA i Wielkiej Brytanii, którzy uczestniczyli w realizacji niniejszego badania, często nie znali takiej koncepcji (Fazlagić 2018b). Jest ona zatem swego rodzaju novum, jeśli chodzi o dokumenty strategiczne dotyczące systemów edukacji. Przedstawiona w tabeli 1. lista stanowi kompromis między koniecznością syntezy zagadnień z analizowanego obszaru a rozległością badanego zagadnienia.

Tabela 1. Konceptualizacja kompetencji proinnowacyjnych

\section{UMIEJĘTNOŚCI POZNAWCZE}

1) Ciekawość i odkrywanie nowych możliwości - uczenie, jak zainteresować innych swoją osobą, i patrzenia w przyszłość; nagradzanie uczniów za zadawanie pytań; nauczanie, jak nie być zadowolonym z pierwszej opcji, zachęcanie do ciekawości i chęci szukania kolejnych możliwości. Uczenie, jak eksperymentować i być otwartym na empiryczną weryfikację swoich założeń.

2) Powstawanie pomysłów - uczenie, jak tworzyć i rozwijać pomysły własne oraz innych. Kompetencja silnie związana z kreatywnością w rozumieniu psychologii.

3) Rozwiązywanie problemów - zdolność do rozwiązywania problemów i przezwyciężania przeszkód. Kompetencji tej towarzyszy postawa proaktywna wobec trudności i wyzwań.

4) Samodzielność myślenia - przełamywanie modeli mentalnych; uczenie, że „nie wszystko złoto, co się świeci"; myślenie niestandardowe, nawet jeśli czasami oznacza niezgodność z powszechną opinią. Identyfikowanie przydatnych źródeł informacji oraz zbieranie i selekcjonowanie tylko tych informacji, które są niezbędne/wartościowe.

5) Myślenie dywergencyjne - nauczanie, jak zmieniać perspektywę i patrzeć na problem z innego punktu widzenia.

6) Kadrowanie problemów - operacjonalizacja abstrakcyjnych obiektów/zjawisk/idei; nauczanie, jak dla abstrakcyjnego i mglistego pojęcia stworzyć wymierne ramy pojęciowe, punkty odniesienia, parametry pomiarowe itp.

7) Praca nad wieloma problemami w tym samym czasie - nauczanie, jak pracować jednocześnie nad kilkoma projektami lub wstępnymi pomysłami bez przedwczesnego wybierania „właściwych” i eliminowania pozostałych. Kompetencja związana z tolerancją dla wieloznaczności (ambiguity).

8) Umiejętność uczenia się - kompetencja związana z umiejętnością uczenia się, a także analizowania, identyfikowania pozytywnych i negatywnych zdarzeń i ich przyczyn; zdolność do doskonalenia i usprawniania istniejących rozwiązań.

\section{UMIEJĘTNOŚCI BEHAWIORALNE}

9) Odwaga i podejmowanie ryzyka - demonstrowanie odwagi i niezależności myślenia, a także zdolności do doceniania wysiłków innych osób. U liderów kompetencja ta wiąże się z nauczaniem odwagi i stawiania czoła wyzwaniom, nagradzaniem „tych, którzy się odważą”. Rozwój tej kompetencji wiąże się z nauczaniem, że niezgadzanie się z autorytetem jest w niektórych sytuacjach pozytywną postawą. Chodzi o kształtowanie u młodzieży zdolności do podejmowania ryzyka w życiu i akceptowania porażek. 
10) Wizualizacja problemu i rozwijanie wyobraźni poprzez przydatne metafory - żyjemy w świecie nadmiaru informacji. Wizualizacja informacji staje się podstawową metodą przezwyciężenia „przeładowania informacyjnego". Uczenie, jak wyjaśniać i nadawać sens światu dzięki komunikacji pośredniej, w tym metaforom, rysunkom, schematom, jest bardzo ważne.

11) Podejmowanie decyzji - branie odpowiedzialności za decyzje, terminowość; branie na siebie odpowiedzialności i zarządzanie ryzykiem.

12) Liderowanie - przewodzenie sobie samemu i innym. Wskazywanie znaczenia dobrego przywództwa dla powodzenia realizacji planu; podejmowanie inicjatywy.

13) Opóźniona lub odroczona gratyfikacja - zdolność do oparcia się pokusie natychmiastowej nagrody i oczekiwanie na późniejsze wynagrodzenie.

14) Zarządzanie zmianą i improwizacja - uczenie, jak improwizować, pracować bez agendy lub poza nią, próbowanie osiągania rezultatów bez wcześniejszych przygotowań, mobilizowanie zasobów ad hoc, uczenie, jak radzić sobie z niepewnością i zmianami, przygotowywanie uczniów na sytuacje, w których kilka interpretacji jest wiarygodnych; ocena sił, które popychają lub hamują pomysł w danej sytuacji.

15) Wytrwałość - znaczenie niepoddawania się; usilne próbowanie, sprawdzanie wszystkich możliwości, niezniechęcanie się zbyt łatwo.

16) Rozwijanie zainteresowań i nauczanie, że posiadanie hobby jest zasobem - Nagradzanie uczniów za rozwijanie zainteresowań; zachęcanie ich do działań nieobjętych programem nauczania.

17) Współpraca - uczenie jak osiągać synergię, wykorzystywać zasoby i umiejętności innych ludzi na zasadach win-win; nauczanie jak słuchać sugestii innych i próbować nowych pomysłów.

18) Rozwijanie orientacji na przyszłość - nauka o zaletach spoglądania na przyszłe możliwości; ocena przyszłych kierunków i ryzyka na podstawie obecnych i przyszłych silnych stron, słabych stron, szans i zagrożeń.

\section{UMIEJĘTNOŚCI FUNKCJONALNE}

19) Podstawowe umiejętności - pisanie, czytanie, liczenie.

\section{UMIEJĘTNOŚCI TECHNICZNE}

20) Podstawowe umiejętności - obsługa programów komputerowych, zrozumienie i wykorzystywanie technologii do doskonalenia procesów w pracy.

Źródło: Fazlagić 2018b, s. 21-23.

Wykorzystując operacjonalizację pojęcia kompetencji proinnowacyjnych przedstawioną powyżej jako kwestionariusz wywiadów półustrukturyzowanych, przeprowadzono łącznie 27 wywiadów z trzema grupami interesariuszy: nauczycielami na poziomie szkolnictwa podstawowego i średniego, urzędnikami w wybranych ministerstwach kultury i oświaty (Kultusministerien) oraz naukowcami specjalizującymi się w edukacji, pedagogice i metodach nauczania. Wyróżniono przy tym rozwiązania zlokalizowane na trzech poziomach: 
$\rightarrow$ poziomie federalnym oraz krajów związkowych,

$\rightarrow$ poziomie instytucji edukacyjnych,

$\rightarrow$ poziomie praktyki nauczania.

Niemiecki system szkolnictwa podstawowego i średniego składa się z czterech głównych obszarów studiów: obszaru elementarnego, obszaru pierwszego, pierwszej fazy drugiego obszaru i drugiej fazy drugiego obszaru (Besonderheiten... 2016). Każdy z nich obejmuje poszczególne rodzaje szkół, które różnią się znacząco w zależności od kraju związkowego. Konferencja Stała Ministerstw Kultury i Oświaty Krajów Związkowych Republiki Federalnej Niemiec (Die Ständige Konferenz der Kultusminister der Länder in der Bundesrepublik Deutschland) określa wytyczne i standardy edukacji, ale przepisy dotyczące kształcenia różnią się znacząco w szesnastu krajach związkowych, co skutkuje szesnastoma niekiedy znacząco rozbieżnymi systemami. Szkoły na ogół mają autonomię w kształtowaniu i wdrażaniu własnych programów nauczania, w których określają swoje priorytety tematyczne czy metodyczne (Deutscher Bildungsserver 2017). Ministerstwa kultury i oświaty opracowują wytyczne dotyczące polityki edukacyjnej, nauki i sztuki, wydają regulacje prawne i administracyjne, komunikują się z najwyższymi władzami federalnymi i kontrolują niższe władze, podległe korporacje, instytucje i fundacje. Aby pomóc ministerstwom, kraje związkowe ustanowiły własne instytuty szkolnictwa wyższego, edukacji i kształcenia zawodowego.

Należy również dodać, że odpowiedzialność za stworzenie katalogu dalszych kursów szkoleniowych spoczywa również na ministerstwach edukacji krajów związkowych. Poprzez sieć doradców zawodowych, którzy uczęszczają na zajęcia w szkołach i omawiają z nauczycielami potrzeby w zakresie edukacji, nauczyciele mają pośredni wpływ na rozwój katalogów kursów kształcenia ustawicznego.

\section{Rozwiązania na poziomie federalnym oraz krajów związkowych}

W toku badań zaobserwowano, że na poziomie federalnym i krajów związkowych obowiązują dobre praktyki kształtujące różne kompetencje proinnowacyjne (zob. tabela 1). I tak, ciekawość i odkrywanie nowych możliwości wynikają z wynajdowania nowych kontekstów i wyzwań. Stąd międzynarodowe programy dające możliwość nawiązania wielu 
kontaktów oraz wymiany międzynarodowej są szczególnie ważnym narzędziem w tym zakresie, wykorzystywanym również w Niemczech. Do programów tych można zaliczyć m.in. Erasmus czy konkurs dla uczniów Youth for Space Challenge - ODYSSEUS II (Bawarskie Ministerstwo Oświaty, Kultury, Nauki i Sztuki 2017f). Na poziomie krajów związkowych Federacji Niemieckiej można zidentyfikować inicjatywy mające na celu organizowanie wymiany międzynarodowej dla uczniów. Program stypendialny „ambasadorowie Bawarii” bawarskiego ministerstwa oświaty daje uczniom mającym 15-18 lat możliwość wyjazdów zagranicznych do wybranych krajów (Bawarskie Ministerstwo Oświaty, Kultury, Nauki i Sztuki 2017g). Ponadto, w ramach parlamentarnego programu patronażowego ze Stanami Zjednoczonymi, młodzież w wieku 15-17 lub młodzi pracujący w wieku 15-24 lat mogą ubiegać się o roczne stypendium na wymianę $w$ USA.

Warto zwrócić uwagę także na programy informacyjne dla uczniów w zakresie możliwości wyjazdów lub zwiększające ich świadomość na temat funkcjonowania integracji międzynarodowej. I tak, w ramach programu ConAct można uzyskać informacje w zakresie kontaktów między młodzieżą z Niemiec i lzraela, a także wsparcie w nawiązywaniu nowych relacji pod kątem wymiany młodzieży (ConAct 2017). Otwarte w 2001 r. centrum koordynacji programu rocznie wspiera ok. 300 projektów pozaszkolnych kształcenia i wymiany na poziomie finansowym i pedagogicznym. Inicjatywa "Europa kinderleicht" [Europa dziecinnie prosta] przygotowuje materiały informacyjne dla dzieci w wieku 9-12 lat na temat funkcjonowania Unii Europejskiej, przyczyn jej założenia oraz działalności na rzecz obywateli (Ministerstwo Szkolnictwa i Kształcenia Kraju Związkowego Nadrenia-Westfalia 2019).

Programy wspierające u młodzieży zdolność do formułowania pomysłów dotyczą różnych aktywności. Po pierwsze, w toku badań literaturowych zidentyfikowano konkursy wspierające przedsiębiorczość. Program Jugend gründet [Młodzież zakłada firmę] wspiera kreatywność i przedsiębiorcze myślenie u uczniów dziesiątej klasy, którzy nie rozpoczęli studiów ani nie ukończyli kształcenia zawodowego. Samodzielnie lub w zespołach sześcioosobowych uczniowie otrzymują możliwość przeżycia wirtualnego procesu zakładania firmy. Zespoły opracowują nowe strategie sprzedaży, plany finansowe, taktyki marketingowe czy innowacje produktowe (Bawarskie Ministerstwo Oświaty, Kultury, Nauki i Sztuki 2017a). 
W Niemczech działają także inicjatywy wspierające niezależne myślenie. Do tej kategorii można zaliczyć nagrody przyznawane przez poszczególne ministerstwa kultury i oświaty, np. Nagroda Klausa Hildebranda w Bawarii z zakresu wyróżniających się prac o tematyce ekonomicznej i finansowej na poziomie szkół ponadpodstawowych w roku szkolnym 2016/2017 (Bawarskie Ministerstwo Oświaty, Kultury, Nauki i Sztuki 2017d). W tym samym kraju związkowym funkcjonuje również program JUNIOR wspierający przedsiębiorczość w szkołach na terenie Bawarii. W jego ramach uczniowie zakładają własne przedsięwzięcie ograniczone czasowo na rok. Przez ten czas przejmują odpowiedzialność za powodzenie swojego przedsiębiorstwa, działającego podobnie do prawdziwej firmy (Bawarskie Ministerstwo Oświaty, Kultury, Nauki i Sztuki 2017b).

W toku przeprowadzonych badań literaturowych, uzupełnionych o rozmowy z ekspertami, można zidentyfikować różne inicjatywy na poziomie ministerstw oświaty, zmierzające do zmiany perspektywy w postrzeganiu uczniów. I tak, bawarski projekt Europa zwischen Tradition und Moderne [Europa między tradycją a nowoczesnością] zakłada pracę zespołów uczniów różnych szkół nad zadaniami z rozmaitych obszarów tematycznych i dziedzin sztuki. W ten sposób uczniowie w różnym wieku i z różnych typów szkół poznają ewolucję europejskiej tradycji i dziedzictwa kulturowego. Podobnie, zakończona już kampania Vielfalt als Chance [Różnorodność jako szansa] miała na celu zwiększenie świadomości przedsiębiorstw, administracji i innych instytucji w dziedzinie etnicznej i kulturowej różnorodności jako istotnego atutu gospodarki niemieckiej i czynnika sukcesu społecznego. Wreszcie, obiecującym projektem w zakresie rozwoju umiejętności przyjmowania odmiennych perspektyw jest międzynarodowa symulacja posiedzeń Organizacji Narodów Zjednoczonych, w której uczestniczą uczniowie szkół. Pracują oni nad uchwałami związanymi z różnymi istotnymi problemami społecznymi i gospodarczymi, szukając kompromisów między różnymi perspektywami.

Umiejętność uwzględniania i rozważania równorzędnych koncepcji jest $w$ Niemczech również wspierana przez instytucje funkcjonujące ponad podziałami administracyjnymi. Adekwatnym przykładem jest tutaj projekt KIEWIS dla uczniów wszystkich krajów związkowych, prowadzony od 2007 r. przez organizację Wissensfabrik. W jego ramach w firmach odbywają się zajęcia, dzięki którym uczniowie mogą 
skonfrontować zdobytą wiedzę z procesami faktycznie zachodzącymi w praktyce gospodarczej. Dzięki temu odkrywają różne wzajemnie powiązane obszary funkcjonowania przedsiębiorstwa, które razem przyczyniają się do realizacji celów organizacji.

Podobnie, konkurs gry biznesowej „Play the Market” jest skierowany do uczniów od dziesiątej klasy, którzy mogą wykorzystać swoją wcześniejszą wiedzę do prowadzenia wirtualnego przedsiębiorstwa. Muszą podejmować decyzje w takich obszarach jak sprzedaż, kadry, finanse czy planowanie zaopatrzenia. Uczestniczące, trzyosobowe zespoły działają na różnych rynkach i bezpośrednio konkurują z innymi firmami.

Z drugiej strony aktywność i podejmowanie ryzyka przez uczniów są wspierane przez takie organizacje jak fundacja Rock It Biz wspomagająca zakładanie firm przez uczniów. W trakcie realizacji projektów uczestnicy muszą rozwinąć pomysł na biznes, pozyskać finansowanie, stworzyć produkt i przemyśleć sposoby jego wprowadzenia na rynek. Dzięki temu młodzież odkrywa swoje predyspozycje i upodobania w ramach pracy zespołowej. Ma przy tym możliwość spotkania się z przedsiębiorcami. Podobną rolę odgrywa inicjatywa ifex Ministerstwa Finansów i Gospodarki kraju związkowego Badenia-Wirtembergia realizowana we współpracy z lokalnym ministerstwem oświaty. Celem podejmowanych działań jest promowanie przedsiębiorczości wśród uczniów i wskazanie jej jako alternatywy dla innych ścieżek zawodowych.

Wykształceniu u uczniów umiejętności podejmowania decyzji sprzyjają inicjatywy na styku praktyki gospodarczej i szkolnictwa. Przykładowo, business@school jest inicjatywą firmy doradczej Boston Consulting Group, w ramach której zespoły uczniowskie zajmują się analizą działalności biznesowej dużych, a także średnich i małych firm. Z tym podstawowym rozumieniem działania modeli biznesowych słuchacze podejmują decyzje na temat kształtowania własnego planu biznesowego i przedstawiają przed szerszą publicznością swoje pomysły na działalność przedsiębiorczą. Podobnie, od 2012 r. funkcjonuje program firm uczniowskich JUNIOR skierowany do uczniów szkół poziomu ponadpodstawowego. W ramach programu uczniowie przez cały rok prowadzą uczniowską firmę, rozdzielając między siebie funkcje typowe dla struktury faktycznej firmy. Sami muszą definiować kluczowe etapy jej działalności, takie jak koncepcja biznesu, założenie, kapitał zakładowy czy sprzedaż produktów. 
Kompetencje proinnowacyjne są ponadto rozwijane na poziomie instytucjonalnym za sprawą inicjatyw na poziomie krajów związkowych i ponad ich granicami. Jednym z programów realizowanych w szkołach w Bawarii jest odpowiedzialne prowadzenie banku przez zespoły uczniowskie pod egidą Federalnego Związku Banków Niemieckich (Bawarskie Ministerstwo Oświaty, Kultury, Nauki i Sztuki, 2017c). Podobnie, projekt Gründerkids [Dzieci-Założyciele] wspiera rozwijanie zdolności przywódczych u uczniów uczestniczących w programach zakładania firm uczniowskich, dzięki organizacji indywidualnych konsultacji, szkoleń i spotkań networkingowych w całym kraju.

\section{Rozwiązania na poziomie instytucji edukacyjnych}

Na szczeblu szkolnym poza wymianami uczniowskimi na uwagę zasługują projekty, mające na celu rozwijanie ciekawości u uczniów i identyfikowanie nowych możliwości, dotyczące np. odkrywania korzeni rodzinnych. Przykładowo w Szkole Podstawowej Siegerland w dzielnicy Berlin-Spandau, w kraju związkowym Berlin od 10 lat prowadzi się projekty eTwinning, w ramach których uczniowie zajmują się poszukiwaniem swoich korzeni rodzinnych w innych krajach Europy. Projekty te zostały wyróżnione europejskimi nagrodami i znakami jakości. Oprócz rozbudzania ciekawości, rozwijają one również znajomość języków obcych. Jednocześnie projekty pozwalają na pogłębianie umiejętności wykorzystywania nowoczesnych technologii i technik poszukiwania informacji (Konferencja Ministerstw Szkolnictwa 2019).

Umiejętność formułowania pomysłów przez uczniów na poziomie organizacji pracy własnej może być w szkołach rozwijana podczas aktywności praktycznych przebiegających poza głównym nurtem nauczania. I tak, w Centrum Szkolnym Wilhelm-Raabe w Eschershausen (kraj związkowy Dolna Saksonia) w 2015 r. rozpoczęto budowę drewnianego budynku obok szkoły we współpracy z partnerami spoza szkoły. Praca przy budowie budynku miała służyć rozwijaniu przedsiębiorczości u uczniów. Dzięki podziałowi obowiązków przy budowie było możliwe rozwinięcie u nich poczucia odpowiedzialności, a także podejmowania inicjatywy i kreatywności. Realizacja własnych pomysłów wymagała również zaangażowania różnych innych osób (np. personelu technicznego) i tym samym wspierała interdyscyplinarność przedsięwzięcia.

Ponadto, w Niemczech duże znaczenie w szkołach mają tzw. wspólnoty pracy (Arbeitsgemeinschaften). Przykładowo, w szkole podstawo- 
wej w Oberstimm od roku akademickiego 2012/2013 zespół uczniów pod okiem nauczycielki prowadził raz $w$ tygodniu badania własne pod hasłem „po drodze we wszechświecie”. Jego wyniki uczniowie przedstawili Berndowi Siblerowi, sekretarzowi stanu ds. kultury, w trakcie jego wizyty w szkole wraz z m.in. planetami wykonanymi z papier mâché i tablicami informacyjnymi czy symulację światła księżycowego. Prezentacja spotkała się z bardzo pozytywną opinią.

Niezależne myślenie może być kształtowane już na poziomie definiowania wewnętrznych celów w programach nauczania w szkołach. I tak, w 2000 r. w Szkole Podstawowej Thomas-Mann-Grundschule (Berlin) wprowadzono wewnętrzny wykaz kompetencji w celu rozwijania u uczniów w trakcie sześcioletniego okresu nauki zdolności do samodzielnego uczenia się i pracy. Do tych celów, wyrażonych w programie nauczania szkoły, należą w szczególności rozwój wiedzy fachowej, kompetencji społecznych i medialnych. Podstawą pracy w grupach o mieszanych klasach 0-2 oraz 3-6 w 2000 r. zespół nauczycieli opracował wspólny program metodyczny. Dla przykładu, celem na koniec czwartej klasy jest samodzielne określenie kolejności zadań we własnym planie tygodnia. Uczniowie wybierają zadania do indywidualnego opracowania, przez co uczą się niezależnego myślenia i planowania swoich działań (Czerwanski, Solzbacher 2004).

Umiejętności te są również rozwijane przez organizację pracy. Zyskującą na popularności koncepcją w Niemczech jest tzw. model Jenaplan, realizowany w szczególności w szkole Jenaplan w mieście Jena (Jenaplan-Schule Jena 2019). W ramach tej koncepcji uczniowie w różnym wieku uczą się we wspólnych grupach projektowych, rozwiązując problemy mimo różnic w stanie wiedzy i dojrzałości. Nie tylko wśród uczniów, lecz również wśród nauczycieli nadrzędną zasadą jest słuchanie innych i wspólne wyciąganie wniosków z odmiennych zdań oraz uczenie się na błędach (Czerwanski, Solzbacher 2004).

Do rozwoju odważnej postawy przyczyniają się aktywności poza salą lekcyjną, sprzyjające rozwijaniu umiejętności brania odpowiedzialności za konkretne działania. I tak, w Centrum Szkolnym Wilhelm-Raabe-Schulzentrum Eschershausen (kraj związkowy Dolna Saksonia) funkcjonowała uczniowska firma zajmująca się produkcją miodu i wosku, która stawia na produkcję ekologiczną i funkcjonuje jak faktyczne przedsiębiorstwo. Uczniowie są odpowiedzialni m.in. za zarządzanie personelem czy gospodarowanie kapitałem (inwestycje, pożyczki, dywi- 
dendy itd.). Ponadto, istotną rolę odgrywają tzw. wspólnoty pracy. Przykładowo w Gerhart-Hauptmann-Schule Griesheim uczniowie rozwijają wyobraźnię i zdolności poznawcze w ramach wspólnoty pracy twórczej, w której wykwalifikowane osoby uczą wytwarzania wyrobów z wełny, pereł, gumek typu loom bands czy nici. Podobnie, we wspólnocie zajmującej się garncarstwem uczniowie z zastosowaniem nauczanych technik wdrażają własne koncepcje, które po ukończeniu stają się ich własnością (Gerhart-Hauptmann-Schule 2019).

Zdolność do samodzielnego podejmowania decyzji w szkołach niemieckich jest uwzględniana m.in. na poziomie kształtowania planu zajęć i realizacji dłuższych projektów. I tak, w ramach nowych metod nauczania w Szkole Podstawowej Thomas-Mann w Berlinie pozwolono uczniom podejmować decyzje $w$ zakresie kształtowania własnego planu zajęć. Przykładowo uczniowie samodzielnie decydują w sprawie czasu niezbędnego do poświęcenia $w$ danym tygodniu na prace $\mathrm{w}$ ramach projektu opracowywanego przez dłuższy czas i wyznaczają sobie terminy kontrolne w tym zakresie (Czerwanski, Solzbacher 2004).

Innym przykładem mogą być projekty realizowane przez szkoły ponadpodstawowe wraz z firmami, jak np. współpraca uczniów w Badenii-Wirtembergii i Margarete Steiff GmbH, w ramach której rozważano, czy firma ta powinna zainwestować w produkcję w Chinach (Kształcenie Ustawiczne Nauczycieli w Badenii-Wirtembergii 2019).

Ważnym elementem rozwijania kompetencji społecznych u uczniów tej szkoły jest przydzielanie tzw. urzędów klasowych, czyli stanowisk związanych z przejęciem odpowiedzialności za jasno zdefiniowane obszary funkcjonowania danej klasy. Uczniowie mogą ubiegać się o "ministerstwa" w ramach rady klasowej w drodze głosowania lub losowania, np. „ministerstwo komputerów" oznacza odpowiedzialność za codzienne uruchamianie sprzętu komputerowego i pilnowanie ich stanu, jak również pomoc techniczną dla innych uczniów. W wybranych przypadkach "minister komputerów" może wprowadzić dla określonych osób zakaz korzystania z komputera.

\section{Rozwiązania na poziomie praktyki nauczania}

Zdolność do formułowania własnych pomysłów na poziomie metod stosowanych w niemieckich szkołach wynika w pierwszej kolejności z częstego stosowania otwartych form prowadzania zajęć, zgodnie $z$ koncepcją często powracającą $w$ niemieckiej literaturze i publicystyce 
z zakresu reform pedagogicznych. Według tego podejścia uczniowie sami definiują swoje cele uczenia się, które chcą osiągnąć za pomocą pracy własnej. Osoba ucząca się ponosi odpowiedzialność za wybór form swojej pracy i treści, a także za planowanie różnych aktywności. Nauczyciel jest przy tym towarzyszem i doradcą. Tym samym zaciera się typowa szkolna hierarchia. Wszystkie zajęcia powinny odnosić się do zainteresowań i zdolności uczących się. Celem swobodnego uczenia się jest bowiem samodzielna nauka i wsparcie relacji społecznych. Uczący się sami znajdują optymalne sposoby nauki (Methodenpool Uni-Koeln 2019a).

Koncepcja otwartych zajęć zakłada połączenie własnej pracy uczniów, pracy według planu tygodniowego, jak również pracy projektowej. Wykorzystanie wielu z tych metod jest cechą otwartego podejścia do zajęć nastawionego na przybliżanie uczniom różnych sposobów rozwiązywania problemów. Koncepcja zajęć zorientowanych na problem zakłada, że nauczyciele i uczniowie wspólnie stawiają pytanie, które stanowi punkt wyjścia dalszej analizy. Ponieważ uczniowie współuczestniczą w formułowaniu problemów badawczych, to również oni muszą wypracować sposoby ich rozwiązania (np. metody laboratoryjne w naukach przyrodniczych). Warto przy tym zaznaczyć, że rozwiązywanie problemów może odbywać się metodą prób i błędów, dzięki zmianie perspektywy, szukaniu analogii do wcześniej rozwiązanych problemów i stosowaniu już wypracowanych strategii czy wreszcie twórczemu podejściu do rozwiązywania problemów (Spörhase-Eichmann 2004).

Innym przykładem metod nauczania i oceny rozwijających samodzielne myślenie jest praca projektowa, w której uczestnicy muszą samodzielnie wypracować narzędzia analityczne, np. zaprojektować ankietę przekazywaną następnie innym uczniom lub pracownikom szkoły. Opracowanie ankiety wymaga określenia celów i zgromadzenia zasobów, by je zrealizować, np. wiedzy z zakresu tworzenia ankiet oraz opracowania wyników (Müller 2006).

Wybór odpowiednich struktur myślowych i poznawczych dla zrozumienia złożonych treści jest istotną umiejętnością, która nie jest powszechnie rozwijana w szkołach, istnieją jednak praktyki mające na celu jej kształtowanie. Należy do nich nauczanie poznawcze (Cognitive Apprenticeship), w którym dąży się do praktycznego pokazania uczniom korzyści płynących z uczenia się, również w zdobywaniu wykształcenia teoretycznego. W tym podejściu, zaczerpniętym z dydaktyki konstruk- 
tywistycznej, rywalizujące ze sobą zespoły uczniowskie poznają np. znaczenie produkcji seryjnej. Analizują ją na podstawie konkretnych "produktów" (np. domków z kartonu), równocześnie mając za zadanie wytworzenie jak największej liczby domków według wzorca. Zespoły musiały same wypracować metodologię „produkcji”, obejmującą różne jej etapy, ich kolejność i powiązania (Methodenpool Uni-Koeln 2019b).

W toku przeprowadzonych badań zidentyfikowano stosowane w Niemczech metody wspierające umiejętność podejmowania decyzji. Praca grupowa, dzieląca się na fazę przygotowania, realizacji, prezentacji i ewaluacji, daje możliwość opracowania zwłaszcza nowych tematów dla uczniów. Dzięki nim muszą oni samodzielnie pogłębić wiedzę w zakresie danej dziedziny, podejmując wspólnie decyzje dotyczące kluczowych zagadnień swojego opracowania. Istotna jest przy tym rola nauczyciela w wyjaśnianiu uczniom reguł skutecznej pracy zespołowej. Metodą uzupełniającą pracę grupową jest metoda moderacji, która stanowi wsparcie w fazach kreatywnych pracy grupowej. Moderatorem decydującym o kierunku prac może być zarówno nauczyciel, jak i wybrany uczeń.

W ramach pracy projektowej uczniowie prowadzą działania zorientowane na cel, a zatem na wynik, które wiążą się z odpowiedzialnością za osiągnięcie danych założeń postawionych w projekcie. Zdefiniowanie sposobu terminowego osiągania danego celu (np. artykuł do gazetki uczniowskiej, raport, sztuka teatralna, piosenka czy prezentacja), w tym organizacja pracy, struktura projektu, podział obowiązków, należą do uczniów (Bauer 2003).

W ramach przybliżania uczniom wyzwań związanych z zagadnieniami zarządzania ludźmi i przywództwa często stosowaną praktyką jest uczenie się poprzez nauczanie. Uczniowie w ramach pracy w grupach lub pracy przed zajęciami przejmują funkcję nauczycieli, którzy mają za zadanie wyjaśniać pozostałej części grupy dotąd przyswojone treści w wybrany przez siebie sposób oraz zgodnie ze swoim stanem wiedzy odpowiedzieć na pytania zespołu. Nauczyciel odgrywa w tym procesie jedynie rolę obserwatora, który nie interweniuje, o ile nie jest to konieczne (Martin 2010).

Podobną rolę odgrywa coraz częściej spotykane w Niemczech sprawowanie funkcji w klasie, jak np. rzecznik klasy czy rzecznik uczniów, które wiążą się z reprezentowaniem interesów danych klas przed radą pedagogiczną czy kierownictwem szkoły (Ustawa o szkolnictwie w Ber- 
linie 2019). Innowacyjną metodą nauczania zyskującą na popularności w Niemczech są symulacje dydaktyczne, w szczególności gry biznesowe. Przykładem może być trzydniowa symulacja na temat polityki komunalnej opracowana przez fundację Friedrich-Ebert-Stiftung i mająca formę hybrydową. Łączy ona symulację i pracę projektową w jednej ze szkół zawodowych o profilu ekonomicznym w Norymberdze, w grupie dwóch klas bankowych liczącej 48 uczniów. Sama praca projektowa była prowadzona przez 31 uczniów, podzielonych na grupy robocze do spraw materiału zdjęciowego, materiału filmowego, strony internetowej, zespołu redakcyjnego, grupy ewaluacyjnej i zespołu organizacyjnego (Kührt 2011).

\section{Podsumowanie i rekomendacje}

$\mathrm{Na}$ podstawie przeglądu literatury $\mathrm{i}$ analizy niemieckiego systemu edukacyjnego można stwierdzić, że w Niemczech rośnie tendencja do powracania do otwartej formy nauczania. Polega ona na tym, że to sami uczniowie określają swoje cele uczenia się, które chcą osiągnąć w ramach pracy własnej, realizowanej w sposób samodzielny i z dużą swobodą. Można zauważyć, że instrumenty wspierające rozwój kompetencji proinnowacyjnych już na poziomie szkolnictwa podstawowego i średniego są zapewniane przez państwo. Dzieje się tak za sprawą jego wytycznych i programów, a także instytucji edukacyjnych, które biorą odpowiedzialność za zapewnienie jakości edukacyjnej, jak również samych nauczycieli, upowszechniających najnowsze metody dydaktyczne.

Aby praktykować prawdziwie przedsiębiorczą filozofię nauczania, nauczyciele powinni stosować metody zachęcające uczniów do otwartości i innowacyjności w rozwiązywaniu problemów. W toku przeprowadzonych badań literaturowych i w rozmowach z nauczycielami stwierdzono natomiast, że wzbudzanie ciekawości nie jest nadal postrzegane jako istotna cecha nauczyciela, ponieważ nieoczekiwane pytania uczniów burzą rytm prowadzonych zajęć, a odpowiadanie na kolejne pytania wymaga czasu i rezygnacji z przekazania pierwotnie zamierzonych treści. W opinii nauczycieli uczniowie o odmiennych poglądach są z reguły postrzegani jako utrudniający nauczycielom prowadzenie zajęć. $Z$ drugiej strony, zależy to jednak od specyfiki dyscypliny i przedmiotu. Przykładowo, w naukach ścisłych zachęca się do odważnego formułowania pomysłów już w ramach studiów pedagogicznych. Zgodnie z koncepcją dydaktyki zorientowanej na proces, 
popełnianie błędów jest motorem zarówno uczenia się, jak i samego nauczania. Jednak w Niemczech w trakcie hospitacji zajęć i praktyk, a także podczas aplikowania na stanowisko nauczyciela, więcej uwagi poświęca się samym błędom niż tolerancji dla nich, zgodnie z zasadą, że nauczyciel nie popełnia błędów.

W ramach niektórych kursów dokształcających wspiera się rozwijanie u nauczycieli zdolności do podejmowania decyzji w złożonych sytuacjach, jednak nie jest to zagadnienie dominujące w studiach przygotowujących do tego zawodu. W opinii nauczycieli umiejętność ta wiąże się jednak ze zdolnością do samodzielnego myślenia i rozwiązywania problemów, którą muszą posiąść sami i przekazywać ją uczniom. Ukończenie danego programu czy kursu dokształcającego nie wiąże się z podwyżką wynagrodzenia. Podwyżki są przewidziane przy zmianie grupy wynagrodzeniowej, ta z kolei zależy od statusu nauczyciela (czy jest urzędnikiem państwowym, czy osobą zatrudnioną), od specyfiki przedmiotu, rodzaju szkoły itd. Awans jest uzależniony nie tylko od stażu zawodowego, ale $w$ dużej mierze również od zaangażowania w pracę organizacyjną lub dodatkowe aktywności w szkole.

Metody nauczania, a zarazem ewaluacji uczniów, wspierające otwarte i elastyczne myślenie coraz częściej bazują na studiach przypadku, podobnie jak w szkolnictwie wyższym. Dzięki tej formie kształcenia uczniowie zdobywają umiejętność samodzielnego rozwiązywania problemów. W Niemczech coraz częściej stosuje się metody uczenia się kooperacyjnego, rozwijające u uczniów zdolność do współpracy. Innowacyjną metodą nauczania zyskującą na popularności w Niemczech są również symulacje dydaktyczne, w szczególności gry biznesowe. Rozwój proinnowacyjnych umiejętności u uczniów wymaga odwołania się do pasji i zainteresowań uczniów. W toku przeprowadzonych studiów literaturowych stwierdzono jednak, że niewiele stosowanych metod nauczania w bezpośredni sposób rozwija zainteresowania uczniów. Bazując jednak na doświadczeniu dydaktyków, można stwierdzić, że coraz częściej taką rolę przejmują wspólnoty pracy. Podobnie, nie zidentyfikowano metod nauczania mających na celu rozwijanie umiejętności generowania różnorodnych pomysłów. Opinie ekspertów współpracujących przy niniejszej analizie wskazują jako słabość niemieckiego systemu nauczania koncentrację zarówno nauczycieli, jak i uczniów na realizacji danego zadania i dotarciu do rozwiązania uznanego za wzorcowe. 
Należy wreszcie zwrócić uwagę na to, że choć takie metody jak burza mózgów czy reguła odwrócenia są wykorzystywane coraz częściej, ich nadal ograniczona częstotliwość wynika również z faktu, że nauczyciele są zbyt świadomi poprawnych rozwiązań, co wywiera wpływ na sposób dochodzenia do odpowiedzi uznawanych za słuszne. Przez to proces formułowania przez uczniów pomysłów własnych nie jest w pełni swobodny. Ponadto same metody oceniania studentów są silnie zorientowane na rezultat, stąd z założenia nie wspierają samodzielnego myślenia. Zarówno w pracy indywidualnej, jak i grupowej uczniowie nie mogą zawsze myśleć liniowo, w rozumieniu sekwencji kroków opisanych według danego schematu, ponieważ w rzeczywistości praca nad danym zadaniem nie przebiega podręcznikowo. Tymczasem w niemieckich szkołach dominuje podejście zorientowane na wynik, zarówno na poziomie metod nauczania, jak i samych metod ewaluacji, co nie wspiera wytrwałości i pomysłowości w pokonywaniu trudności. Przez ciągłe ćwiczenie rozwiązywania problemów uczniowie muszą mierzyć się z nowymi wyzwaniami, jednak rolą nauczyciela jest rozwijanie u uczniów wewnętrznej motywacji do nauki, ponieważ to z niej wynika cierpliwość w pokonywaniu trudności. Przedstawione w tym rozdziale dobre praktyki stosowane w Niemczech, a także opisane deficyty i bariery mogą stanowić inspirację dla krajów reformujących swoje szkolnictwo, w tym Polski. 


\title{
Kompetencje mięlkie \\ w międzynarodowym kształceniu \\ zawodowym na przykładzie \\ szkolenia EDTECH
}

\author{
Monika Tomczyk
}

Boosting Business Integration Through Joint Vocational Education and Training (BBVET) to projekt badawczo-rozwojowy mający na celu wzmocnienie umiędzynarodowienia kształcenia zawodowego (VET) w regionie Morza Bałtyckiego. Projekt jest wspófinansowany $z$ funduszy INTERREG South Baltic Programme i stanowi część strategii Unii Europejskiej dla regionu Morza Bałtyckiego. BBVET rozwinął i wdrożył dziesięciomiesięczny międzynarodowy program kształcenia wykwalifikowanej kadry zawodowej w kierunku EDTECH. Oferuje on firmom możliwość dzielenia się doświadczeniami z 40 młodymi, zmotywowanymi ludźmi z pięciu krajów: Danii, Litwy, Niemiec, Polski i Szwecji. Projekt BBVET działa jako rodzaj agencji mobilności zawodowej i wspiera pobyt za granicą we wszystkich trzech fazach: przygotowania, wdrożenia i kontynuacji - nie tylko organizacyjnie, ale też finansowo. Niniejszy rozdział przedstawia model umiędzynarodowienia edukacji - unikalny, innowacyjny program nauczania opracowany z uwzględnieniem wymogów kształcenia w kierunku EDTECH oraz potrzeb rynku pracy. Ten program nauczania kładzie duży nacisk zarówno na umiejętności twarde, jak i na rozwój umiejętności miękkich.

\section{Słowa kluczowe: \\ mobilność \\ edukacja zawodowa \\ umiejętności miękkie \\ umiędzynarodowienie edukacji \\ EDTECH}




\title{
Soft skills in the International \\ Vocational Education \\ - an example of EDTHCH
}

\author{
Monika Tomczyk
}

Boosting Business Integration Through Joint Vocational Education and Training (BBVET) is a research and development project aiming to strengthen the internationalization of Vocational Educational Training (VET) in the Baltic Sea Region. It is funded by the INTERREG South Baltic Programme and embedded in the European Union strategy for the Baltic Sea Region. South Baltic is an interregional labour market for international business cooperation with access to a new skilled and qualified labour force. BBVET International Training Year is a ten-month programme which offers companies an opportunity to share experiences with young motivated people from five countries in the EdTech sectors, involving 40 students and 5 countries, namely: Denmark, Germany, Lithuania, Poland and Sweden. The BBVET project is as a kind of occupational mobility agency and supports the stay abroad in all three phases: preparation, implementation, and follow-up - not exclusively organizationally, but also financially. This paper presents a model of internationalization, the unique, innovative curriculum developed for the EDTECH education as well as need of market. Innovative curriculum put as much emphasis on the hard skills as well to the soft skills development.

\section{Keywords:}




\section{Wprowadzenie}

Istnieje wiele wyników badań w dziedzinie kształcenia i szkolenia zawodowego, zarówno krajowych, jak i międzynarodowych. Jednym $z$ nich jest Boosting Business Integration Through Joint Vocational Education and Training (BBVET). BBVET działa jak swego rodzaju agencja mobilności zawodowej i wspiera pobyt za granicą we wszystkich trzech fazach: przygotowania, wdrożenia i kontynuacji mobilności-nie tylko organizacyjnie, ale również finansowo. Według definicji przedstawionej w projekcie agencje mobilności zawodowej to jednostki wspierające obecnych lub przyszłych uczniów kierunków zawodowych w dostosowywaniu się do wymogów dynamicznego rynku pracy. Ułatwiają dokształcenie się lub zmianę zawodu, nabycie kompetencji międzykulturowych czy praktycznej wiedzy wymaganej w konkretnym zawodzie. W rozdziale przedstawiono model umiędzynarodowienia edukacji zawodowej, który jest innowacyjnym, unikalnym programem nauczania w kierunku EDTECH, który bierze pod uwagę potrzeby studentów, szkół oraz rynku pracy. Program ten może być postrzegany jako innowacyjny z dwóch powodów. Po pierwsze, ponieważ kładzie równie duży nacisk na rozwijanie zarówno umiejętności zawodowych, jak i kompetencji miękkich. Po drugie, dlatego że w jego ramach po raz pierwszy przeprowadzono edukację zawodową w zakresie EDTECH na arenie międzynarodowej.

\section{Innowacyjne kształcenie zawodowe w środowisku międzynarodowym}

Definicja kształcenia i szkolenia zawodowego jako sektora systemu edukacji stwarza problem. W większości przypadków kształcenie ogólne i akademickie jest postrzegane jako rozwijające umiejętności analityczne, wiedzę i umiejętność krytycznego myślenia, natomiast kształcenie i szkolenie zawodowe - jako zwiększające zdolności praktyczne, dzięki umożliwieniu zdobycia doświadczenia i praktycznemu rozwiązywaniu problemów. To proste rozróżnienie nie zawsze znajduje zastosowanie w praktyce. Dobremu mechatronikowi lub mechanikowi, który musi dokonywać rutynowych rozstrzygnięć, aby rozwiązywać problemy, potrzebne są umiejętność myślenia krytycznego i umiejętności analityczne. Podobnie, dobry projektant potrzebuje różnorodnych umiejętności praktycznych, aby nauczyć się obsługi klienta. Aby wypełnić lukę w edukacji zawodowej 
i przetestować różne podejście do kształcenia zawodowego, opracowano i wdrożono projekt BBVET. Stanowi on platformę współpracy między studentami - potencjalnymi pracownikami i pracodawcami. Platforma jest łącznikiem między studentami a rynkiem pracy - zapewnia aktualne szkolenia i przyuczanie do zawodu dostosowane do indywidualnych potrzeb.

W edukacji innowacyjność definiuje się zwykle niepoprawnie lub niekonsekwentnie, co utrudnia zrozumienie sposobu wykorzystania innowacji do osiągnięcia lepszych wyników w nauczaniu. Innowacje w kształceniu dzięki dostarczaniu nowych metod sprzyjają rozwiązywaniu problemów systemu edukacji, usuwaniu (istniejących od dawna) barier w realizacji działań dydaktycznych i edukacyjnych, a także budują zdolności wdrożeniowe. Robią to dzięki:

$\rightarrow$ kreowaniu nowych rozwiązań lub usunięciu tradycyjnych barier dla istniejących działań w zakresie nauczania i uczenia się;

$\rightarrow$ określeniu wcześniej niezidentyfikowanej potrzeby lub bariery, a następnie wzmocnieniu nauczania i uczenia się za sprawą innowacyjnego podejścia, ponownej analizie czynnika ograniczającego i odpowiednie reagowanie;

$\rightarrow$ wprowadzeniu nowych możliwości poprawy nauczania i uczenia się w celu osiągania lepszych wyników; oraz

$\rightarrow$ umożliwieniu systemowi edukacji dostosowania się do nowych ścieżek kształcenia studentów.

Reasumując, innowację w edukacji utożsamia się z poprawą systemu kształcenia, ale nie jest to poprawa przez zwykłą biegłość w standardowej praktyce (Redding, Twyman, Murphy 2013).

W latach 2017-2019 konsorcjum BBVET skupiło się na rozwoju modułowych międzyregionalnych programów kształcenia i szkolenia zawodowego w regionie południowego Bałtyku. Celem było opracowanie programu szkoleniowego, który z jednej strony uwzględniałby kontynuację kształcenia zawodowego i struktur szkoleniowych w sektorze EDTECH, z drugiej zaś, stworzyłby unikalny międzyregionalny system edukacji, wykorzystujący specyfikę międzynarodową tego regionu. Od stycznia $2018 \mathrm{r}$. testowano międzynarodowy program VET - EDTECH. Faza testowa otwarta była dla młodych ludzi w wieku od 18 do 35 lat, w tym siedmiu studentów z Polski. Rysunek 1 przedstawia fazy tworzenia i testowania programu kształcenia EDTECH. 
Rysunek 1. Proces tworzenia i wdrażania programu kształcenia BBVET

\section{BENCHMARKING CURRICULUM}

MAPOWANIE OBECNEGO STANU EDUKACJI EDTECH

OPRACOWANIE CURRICULUM 4 X 10 TYGODNI

ECVET DOKUMENTACJA:

- MoU • Wyniki modułów · Weryfikacja i dokumentacja osiągnięć

\section{WALIDACJA I UZNANIE WYNIKÓW}

Źródło: opracowanie własne.

Proponowany system edukacji musiał uwzględniać systemy edukacyjne w poszczególnych krajach. Oprócz klasycznego szkolnego kształcenia zawodowego w Polsce, Danii, Szwecji i na Litwie, należało wziąć pod uwagę niemiecki model kształcenia zawodowego. Tak zwany system dualny obejmuje połączenie kształcenia teoretycznego i praktycznego kształcenia zawodowego, które jest de facto wstępnym kształceniem zawodowym. Osoby odbierające edukację zawodową w systemie dualnym zazwyczaj odbywają trzyletni staż w szkole i w miejscu pracy zgodnie $z$ wybranym przez siebie zawodem lub w specjalistycznych szkołach zawodowych z nadzorem państwa. Zarówno partnerzy z poszczególnych krajów związkowych, jak i na szczeblu państwa zaangażowani są w dualny system edukacji w Niemczech. W procesie tym uczestniczą zatem następujące podmioty: państwo, partnerzy społeczni - przedstawiciele pracodawców i pracowników, oraz izby handlowe i przemysłowe lub izby rzemieślnicze. System dualny kształcenia zawodowego jest nieelastyczny i koncentruje się na rynku lokalnym.

Mimo to stworzono i wdrożono model pobudzania biznesu dzięki edukacji VET. Kształcenie BBVET nawiązuje do modelu opartego na metodyce zarządzania cyklem projektu (PCM) i składa się z ośmiu etapów realizacji programu kształcenia. Etapy te zostały przedstawione 
na rysunku 2. Etap 1 to marketing i rekrutacja kandydatów w pięciu krajach biorących udział w projekcie. Etap 2 - określenie indywidualnych celów edukacyjnych kandydatów. Etap 3 - dopasowanie do indywidualnych potrzeb przez dobranie odpowiednich firm oraz odzwierciedlenie ich w tematyce szkoleń. Etap 4, który nakłada się na etapy 5, 6 i 7, to indywidualny coaching, czyli monitorowanie i wzmacnianie procesu rozwoju i zdobywania nowych kwalifikacji podczas szkoleń, stażu. Etapy $5,6,7$ to elementy etapu kształcenia, po których następuje walidacja osiągniętych wskaźników.

Rysunek 2. Model kształcenia BBVET

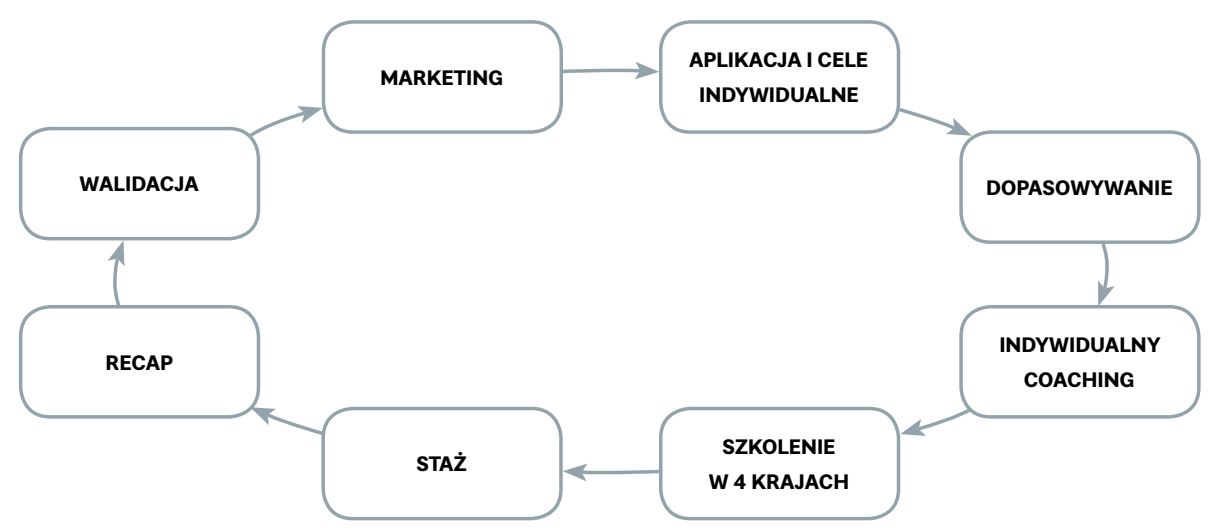

Źródło: opracowanie własne.

Programy kształcenia i szkolenia zawodowego BBVET łączą w sposób unikalny umiejętności twarde i miękkie, z uwzględnieniem wyjątkowych ponadnarodowych doświadczeń edukacyjnych. Aby prześledzić indywidualny rozwój osobistych umiejętności miękkich po roku szkolenia BBVET w projekcie wykorzystano narzędzie do ich pomiaru. Zdecydowano się utworzyć grupę referencyjną w celu określenia poziomu rozwoju studentów, którzy pozostali w kraju, i porównania ich z wynikami uczniów uczestniczących w programie. Dlatego też badanie obejmuje zarówno studentów z tzw. grupy referencyjnej w każdym kraju partnerskim (Dania, Litwa, Niemcy, Polska, Szwecja), jak i studentów BBVET. 
Pomiar zmian, jakie zachodzą wśród uczestników szkoleń i nabytych przez nich kompetencji, daje instytucjom szkoleniowym możliwość wyróżnienia się i zróżnicowania w porównaniu z innymi programami edukacyjnymi, a tym samym przedstawienia bardzo rzetelnej i realnej oferty dla przyszłych studentów i przedsiębiorców. Jak już wspomniano, model BBVET opiera się na zarządzaniu cyklem kształcenia, którego etapy przedstawiono na rysunku 2. Każdy cykl jest ewaluowany i wpływa na zmiany podejmowane w kolejnym obrocie. Taka struktura umożliwia wypełnienie luk i niedoskonałości poprzedniej rotacji. Każdy obrót odbywa się w ośmiu etapach:

$\rightarrow$ Marketing studencki - rozpowszechnianie informacji o szkoleniach wśród studentów potencjalnie zainteresowanych edukacją EDTECH i mechatroniką.

$\rightarrow$ Aplikacja $z$ indywidualnymi celami - zainteresowane osoby rejestrują się na platformie. Z każdą z nich przeprowadza się indywidualny wywiad, którego celem jest określenie poziomu wiedzy na dany temat, a także gotowości do współpracy w grupie i podjęcia edukacji międzynarodowej, która wiąże się z mobilnością i pobytami za granicą.

$\rightarrow$ Dopasowywanie się - uwzględnia się indywidualne potrzeby każdego uczestnika. Jego ścieżka rozwoju i proces uczenia się są dobierane w taki sposób, aby mógł osiągnąć cele indywidualne.

$\rightarrow$ Indywidualny coaching - dostarcza sposobów na aktywizację samoświadomości ucznia, jego własnych umiejętności rozwiązywania problemów i pomaga w osiągnięciu celu. Trener, zamiast udzielania rad i pomocy - w postaci gotowych odpowiedzi i rekomendowania działań, zadaje uczniom pytania, które prowadzą ich do sformułowania własnych odpowiedzi i planowania działań prowadzących do osiągnięcia celu. Coaching wymaga specjalnej postawy ze strony trenera - postawienia ucznia w centrum procesu rozwoju (gdzie znajduje się także i sam coach).

$\rightarrow$ Relacja trener - student wymaga zaufania, które powinno być utrzymane bez względu na to, jak bardzo trudny może okazać się proces. Ważne jest, aby trener stosował specjalne metody dostosowane do zdolności ucznia i miał takie umiejętności, jak aktywne słuchanie. Trenerzy BBVET korzystają z narzędzia zwanego integralną mapą coachingu, które pomaga monitorować 
i dokumentować proces z całej dostępnej perspektywy, korzystają również z list kontrolnych oraz z modelu biznesowego You (Ostervalder 2010). Coaching jako metoda zaangażowania zatem bardzo różni się od pozostałych metod, takich jak doradztwo czy wykłady.

$\rightarrow$ Zaufanie pozwala trenerowi zadawać głębsze pytania, stawiać wyzwania i motywować ucznia oraz wreszcie trener może uszeregować i usystematyzować hierarchie między różnymi punktami widzenia - co jest szczególnie potrzebne w okresie długotrwatego przebywania poza domem.

$\rightarrow$ Kursy wprowadzające w każdym kraju - kurs trwa 40 tygodni. Prowadzony jest w czterech krajach, w każdym studenci spędzają dziesięć tygodni. Konsorcjum opracowało międzynarodowy program nauczania z zakresu mechatroniki oraz unikalny, oryginalny kurs EDTECH. Wszystkie cztery części kursu są ze sobą powiązane i tworzą dobrze zaprojektowaną układankę, która pomaga studentom rozwijać się indywidualnie i w grupach. Oprócz umiejętności twardych kurs obejmuje warsztaty umiejętności miękkich dostosowanych do procesu grupowego Tuckmana. Cztery fazy procesu grupowego to: formowanie się grupy (forming), konflikt w grupie (storming), powstanie reguł funkcjonowania grupy (norming) i działanie grupy (performing).

$\rightarrow$ Dla każdej fazy opracowano zestaw zajęć, które pomagały studentom w odnalezieniu się w nowej sytuacji, a także w zrozumieniu dynamiki grupy i świadomym uczestniczeniu w procesie.

$\rightarrow$ Praktyki-kurs oznacza zarówno zdobycie wiedzy teoretycznej, jak i współpracę z biznesem. Studenci zdobywają doświadczenie w pracy z klientami biznesowymi.

$\rightarrow$ Podsumowanie - dwudniowa prezentacja wyników osiąganych przez studentów w danym kraju. Na podsumowanie zaprasza się przedstawicieli potrójnej helisy - biznesu, nauki i polityków. Ponieważ projekt na każdym etapie jest inny, dokonuje się oceny danego okresu.

$\rightarrow$ Walidacja -działania mające na celu potwierdzenie w udokumentowany i spójny sposób, że procedury, procesy, sprzęt, materiały, działania i systemy rzeczywiście prowadzą do założonych wyników. 


\section{Pomiar wpływu umiejętności miękkich na edukację}

Trudna i gwałtownie zmieniająca się sytuacja dzisiejszej gospodarki powoduje, że nowi absolwenci nie są już usatysfakcjonowani pozyskaną w systemie edukacji wiedzą akademicką, tym bardziej że studenci potrzebują doskonalenia umiejętności, co zwiększy ich szanse na dobre zatrudnienie (Wilson 2011). Czym są "umiejętności miękkie" i dlaczego są one tak ważne? W trakcie szkolenia studenci zdobywają wiele umiejętności zawodowych, co oznacza, że są praktykantami. Stają się częścią wykwalifikowanej siły roboczej potrzebnej w gospodarce. Aby zarządzać "twardymi umiejętnościami”, muszą również nabyć wiele "umiejętności miękkich". Te, które ostatecznie pozyskają, będą wynikać $\mathrm{z}$ ich indywidualnych predyspozycji.

Istnieje sześć umiejętności miękkich, które mogą decydować o tym, jaki może być nasz wkład w pracę dla danego pracodawcy, a tym samym, w jaki sposób możemy w pełni wykorzystać wiedzę zawodową i stać się wykwalifikowaną siłą roboczą. Są to:

$\rightarrow$ komunikatywność,

$\rightarrow$ zdolność do współpracy,

$\rightarrow$ zapał do nauki,

$\rightarrow$ postawa prospołeczna,

$\rightarrow$ dojrzałość,

$\rightarrow$ zdolność do rozwiązywania problemów (National Skills Task Force 2000).

Pracodawcy wskazali, że absolwenci, którzy obecnie wchodzą na rynek pracy, nie posiadają takich umiejętności miękkich (Woo 2006). Na przykład w niektórych zawodach bardzo ważne jest, aby umieć współpracować, być prospołecznym i komunikatywnym, ale inne zawody będą wymagały innych umiejętności miękkich, takich jak większa niezależność, dojrzałość i zdolność do rozwiązywania problemów. Ponadto wiedza, odpowiednia postawa i umiejętności wydają się decydujące w miejscu pracy, które ostatecznie kształtuje studenta i sprawia, że jest chętny do rozwijania się i pogłębiania swoich kompetencji (Harvey, Locke, Morey 2002).

W ostatnich latach nastąpiła zasadnicza zmiana wymagań, które pracodawcy stawiają kandydatom do pracy. Przedkładają oni umiejętności miękkie nad umiejętności techniczne (Judhi, Pa'wan, Othman, Moksin 2010). Jak wskazuje Payne (2000), to właśnie te umiejętności 
osobiste są teraz, przynajmniej teoretycznie, najbardziej poszukiwane przez pracodawców (Department for Education and Employment 2008).

W celu zmierzenia i oceny umiejętności miękkich w międzynarodowym programie nauczania zastosowano klasyczny czteropoziomowy model oceny (Kirkpatrick 2006):

$\rightarrow$ 1. postawa ucznia, tzn. poziom jego motywacji, a tym samym zdolność do rozwiązania zadania;

$\rightarrow$ 2. wiedza, którą student musi posiadać, aby wykonać zadanie;

$\rightarrow$ 3. zachowanie, tzn. czynności, które uczący się musi opanować, aby móc rozwiązać zadanie; oraz

$\rightarrow$ 4. wyniki, tzn. ogólny poziom uczniów i ich zdolność do rozwiązywania zadań, a tym samym wynik pierwszych trzech poziomów.

Rysunek 3. Piramida umiejętności miękkich według Kirkpatricka

\section{WYNIKI}

\section{ZACHOWANIE}

\section{WIEDZA}

\section{POSTAWA}

Źródło: Beyond Smiley Sheets: Measuring the ROI of Learning and Development.

Dopiero suma umiejętności zawodowych i umiejętności miękkich daje pełen obraz przygotowania studenta do pracy oraz efektów całego szkolenia, a tym samym pozwala określić poziom ROI - zwrotu $z$ inwestycji w nauczanie, dla każdego indywidualnego interesariusza $w$ procesie uczenia. Aby sprostać zmieniającym się warunkom na rynku 
pracy i zapewnić studentom jak najlepsze możliwości rozwoju zawodowego, musimy zapewnić lepsze wykształcenie.

Elastyczne sposoby uczenia się, które mają swój punkt wyjścia m.in. w indywidualnych umiejętnościach, zainteresowaniach, są niezależne od czasu i miejsca (Malhi 2010). Studenci BBVET mają dostęp do wirtualnej platformy, na której mogą przechowywać swoje dane: z podręczników, instrukcji, zadań, planów nauczania, indywidualnego coachingu, testów i egzaminów, a także filmy i kontakty, oraz korzystać z nich w odpowiednich dla siebie warunkach i czasie.

Przy tworzeniu platformy wykorzystano teorię H. Gardnera siedmiu form inteligencji (+1) i różnych stylów uczenia się, które uczniowie mogą preferować. Są to:

$\rightarrow$ inteligencja językowa i werbalna - uczniowie zdobywają wiedzę, czytając, pisząc i grając w gry werbalne;

$\rightarrow$ inteligencja logiczno-matematyczna - uczniowie koncentrują się bardziej na systemach i figurach, lubią eksperymentować i zadawać pytania;

$\rightarrow$ naturalna mądrość - uczniowie potrafią dobrze rozpoznać i sklasyfikować otaczający ich świat oraz odnaleźć wzorce i konteksty;

$\rightarrow$ inteligencja przestrzenna/wizualna - uczniowie, którzy lubią sztukę, czytają mapy i wykresy oraz myślą obrazami;

$\rightarrow$ inteligencja fizyczna - uczniowie przetwarzają wiedzę poprzez doznania fizyczne i eksplorację otoczenia;

$\rightarrow$ inteligencja muzyczna - uczniowie są wrażliwi na dźwięk w swoim otoczeniu i wolą słuchać muzyki podczas nauki lub czytania;

$\rightarrow$ inteligencja osobista - uczniowie przejawiają dużą pewność siebie i niezależność;

$\rightarrow$ inteligencja społeczna - uczniowie lubią kontakt z innymi ludźmi, mają wielu przyjaciół i biorą udział w zajęciach społecznych. Rozwijają się i lepiej uczą się w grupie.

Mając na uwadze różne rodzaje inteligencji uczniów oraz różne style uczenia, można dobrać odpowiednie techniki, które prowadzą do szybszej nauki i sukcesu ucznia. W programie nauczania wyróżniono kilka typów uczniów:

$\rightarrow$ Reflektor. Motto: „Spójrz na problem z kilku punktów widzenia”. Ulubione pytania: „Może istnieje kilka sposobów, aby to zrobić?”. 
$\rightarrow$ Teoretyk. Motto: „Wdrażaj swoją praktykę, używając najlepszej teorii". Ulubione pytanie: „Do czego się to odnosi?".

$\rightarrow$ Pragmatyk. Motto: „Teoria musi działać w praktyce - w przeciwnym razie spróbujemy innej”. Ulubione pytanie: „Kiedy można to przełożyć na praktykę?".

$\rightarrow$ Aktywista. Motto: „Działaj - spróbuj!!. Ulubione pytania: „Co nowego? Nie powinniśmy po prostu spróbować?".

\section{Metodologia prowadzenia badań}

Badania zostały przeprowadzone wśród interesariuszy kształcenia i szkolenia zawodowego (przedstawicieli szkół oraz pracodawców) oraz studentów kształcenia zawodowego i dotyczyły trzech obszarów, tzw. czytania, pisania i arytmetyki, które są klasyfikowane jako wiedza, współpraca, komunikacja i krytyczne myślenie, uznawane za umiejętności miękkie. Wywiady opierały się na porównywaniu wiedzy z umiejętnościami zdobywanymi w czasie procesu kształcenia. W badaniu główny nacisk położono na to, w jaki sposób instytucje edukacyjne rozwijają swoją ofertę dla uczniów, aby stali się oni wykwalifikowaną kadrą roboczą oraz dobrze funkcjonowali w społeczeństwie. Jakie elementy są potrzebne do aktywnego uczenia się? Jak interesariusze myślą o tym, co zrobić, aby położyć większy nacisk na wiedzę lub umiejętności?

\section{Metodologia badań jakościowych}

Ustrukturyzowany wywiad został przeprowadzony podczas czterech spotkań tzw. RECAP DAYS - dni podsumowujących kolejne etapy edukacji. Dwa pierwsze odbyły się w marcu 2018 r. w Szwecji, trzeci i czwarty w Polsce i na Litwie w maju 2018 r. Przeprowadzono badania na grupie 16 osób z czterech krajów.

\section{Kluczowe odkrycia}

Respondenci podkreślali, że szkoły powinny lepiej przygotowywać uczniów do wejścia na rynek pracy. Zauważono, że obecnie szkoły koncentrują się głównie na trzech wspomnianych obszarach, tj. czytaniu, pisaniu i matematyce, nie wykonując jednocześnie odpowiedniej pracy pod względem aspektów społecznych, współpracy i pracy zespołowej. Rysunek 4 pokazuje, które tematy są najczęściej omawiane i wybierane w szkołach według ekspertów. 
Większość z nich zapytana, dlaczego tak mało czasu poświęca się kompetencjom miękkim, podkreślała nieznajomość metodologii kształcenia u trenerów, brak narzędzi do pomiaru i oceny ich wzrostu oraz niechęć samych uczniów do poszerzania wiedzy w tym zakresie.

Rysunek 4. Lista dyskutowanych tematów w szkole,

zaznaczona jako ważna lub bardzo ważna

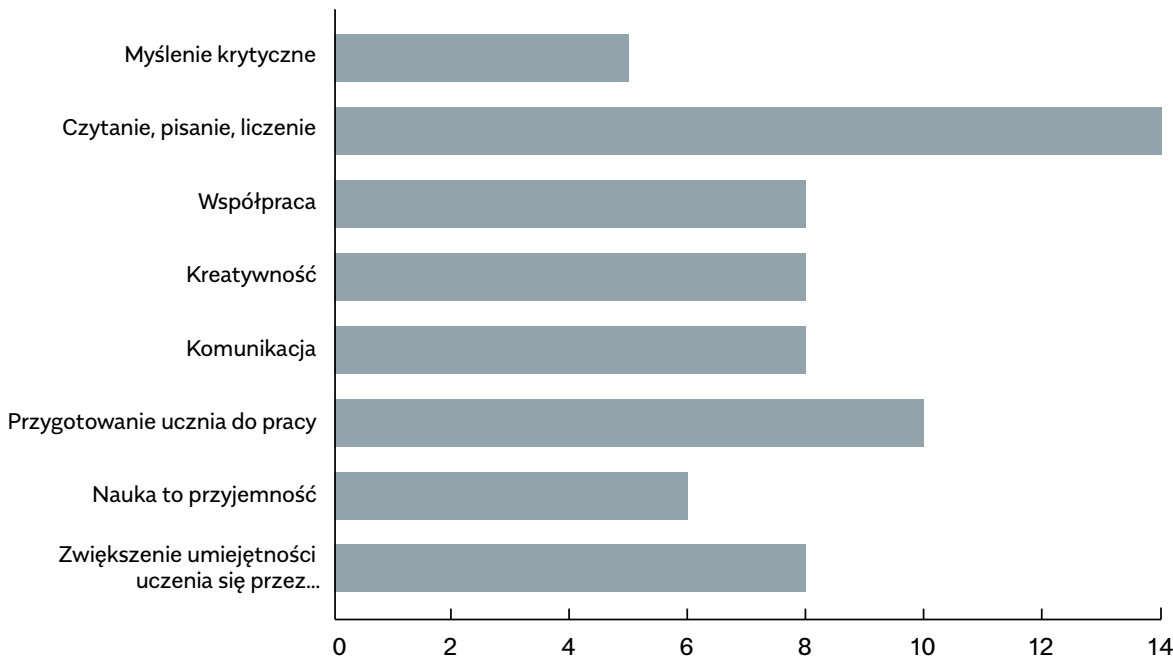

Źródło: opracowanie własne.

Podkreślano, że umiejętność rozwiązywania problemów i współpracy są dwiema najważniejszymi umiejętnościami miękkimi, na których powinna opierać się edukacja.

Wielu respondentów podkreślało, że w tradycyjnym szkolnictwie zawodowym projekty grupowe są realizowane w szkołach, ale brakuje moderowania grupy i wyjaśniania, jak ona funkcjonuje i co dzieje się z nią w czasie. Mimo prób pracy w grupach nadal mamy do czynienia z pracą indywidualną i indywidualnym podejściem do zadań. Zainteresowane strony uważają, że szkoły zbytnio koncentrują się na "nauczaniu na potrzeby testu", pracy w pojedynkę (tylko w pojedynkę) i na indywidualnych osiągnięciach, natomiast praca zespołowa, osiągnięcia grupowe i współpraca z innymi poza klasą są niedoceniane: 10 z 16 ankietowa- 
nych uważa, że zbyt duży nacisk kładzie się na nauczanie, aby zdać obowiązkowe standardowe testy.

Oczywiste jest również, że wiele szkół uważa, że zbytnio skupiają się na osiągnięciach indywidualnych i że uczniowie za dużo pracują sami - 8 z 16 zdecydowanie zgadza się z tym stwierdzeniem.

Zainteresowane strony stwierdziły, że współpraca z innymi uczniami poza klasą jest zbyt mała, zbyt mały nacisk kładzie się na osiągnięcia grupowe i pracę zespołową.

Podkreśliły, że umiejętność współpracy jest kluczowym elementem budowania dojrzałego społeczeństwa i wspierania rozwoju gospodarczego.

Czy w XXI w. technologia może pomóc w nabyciu umiejętności miękkich? Niektóre rodzaje technologii, takie jak komputery czy internet, istnieją od dziesięcioleci i są wykorzystywane w nauczaniu. Technologie cyfrowe dopiero zaczynają docierać do klas za sprawą inicjatyw edukacyjnych wprowadzania nowego sprzętu, cyfrowych publikacji (e-booki) i nowych rodzajów narzędzi oceny. W tym kontekście można powiedzieć, że technologia dopiero wchodzi do edukacji i jest wystarczająco dojrzała, by służyć jako narzędzie do wspólnego uczenia się.

Ankietowani eksperci uważają, że do poprawy sposobu, w jaki umiejętności współpracy są przekazywane osobom uczącym się, potrzeba znacznie więcej niż tylko wdrażania technologii, czyli holistycznego podejścia do edukacji. Na rysunku 5 przedstawiono wymienione przez respondentów czynniki wpływające na poprawę edukacji.

Rysunek 5. Czynniki, które mogą mieć wpływ na współczesną edukację zawodową

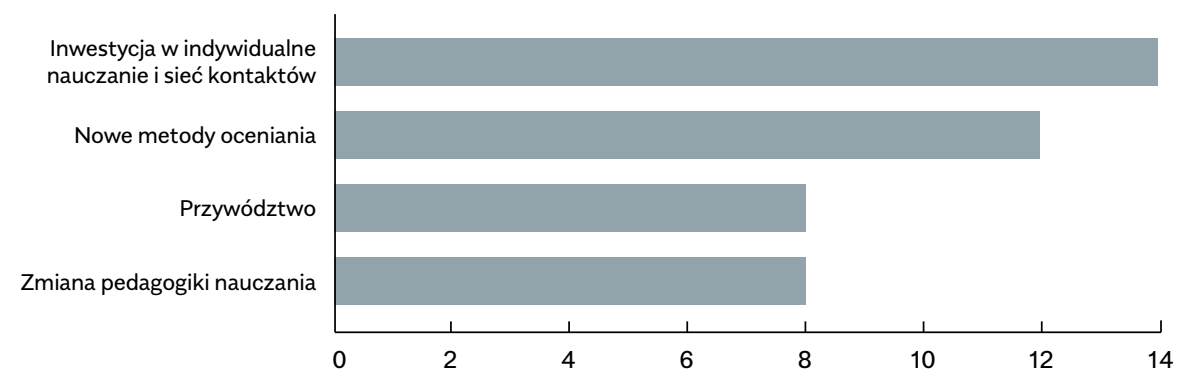

Źródło: opracowanie własne. 


\section{Podsumowanie}

Według badania kadry pracowniczej jest bardzo wiele do zrobienia, aby zwiększyć liczbę dorosłych, którzy pogłębiają swoją wiedzę i uczestniczą w programie uczenia się przez całe życie. Według badania umiejętności osób dorosłych OECD (PIAAC) 20\% populacji aktywnej zawodowo w UE ma niskie umiejętności czytania, pisania i liczenia, a 25\% dorosłych nie posiada umiejętności skutecznego korzystania z technik komputerowych i informacyjnych.

Ostatnie badania przeprowadzone pod kątem kształcenia zawodowego (CEDEFOP 2012) pokazują, że absolwenci europejskiego kształcenia i szkolenia zawodowego odnoszą większe sukcesy w znalezieniu zatrudnienia niż kandydaci z wykształceniem ogólnym. Dotyczy to w szczególności absolwentów programów kształcenia i szkolenia zawodowego o silnej orientacji na miejsce pracy. Te same dane pokazują również, że absolwenci kształcenia i szkolenia zawodowego są lepiej opłacani niż kandydaci z wykształceniem ogólnym. Jednak atrakcyjność i jakość kształcenia i szkolenia zawodowego znacznie różnią się w poszczególnych krajach.

Atrakcyjność kształcenia i szkolenia zawodowego to wielowymiarowa koncepcja, która zależy od unikalnej charakterystyki systemu poszczególnych krajów. Podczas spotkania ekspertów zwołanego przez koordynatora Bałtyckiej Strategii ds. Edukacji Andersa Bergströma, które odbyło się w Ministerstwie Spraw Zagranicznych w Warszawie w maju 2018 r., omawiano sytuację szkolnictwa zawodowego ze szczególnym uwzględnieniem specyfiki Polski. Kształcenie zawodowe w Polsce nie cieszy się dobrą opinią i wybór tej ścieżki edukacyjnej jest traktowany jako życiowa porażka. Podejmowanie kształcenia zawodowego wiąże się ze stereotypami dotyczącymi braku pracy, pieniędzy oraz bardzo nudnego i nieudanego życia, a szkoły zawodowe oferują tradycyjne kierunki studiów, które nie leżą dziś w centrum zainteresowania młodzieży.

Jak wspomniano, kompetencje miękkie są uznawane przez nowoczesnych pracodawców za bardzo ważne w procesie rekrutacji. Jednak w większości przypadków kandydaci nie spełniają wymogów i nie posiadają tych kompetencji. Istnienie dobrze wykwalifikowanej kadry o wysokich kompetencjach międzykulturowych jest wynikiem współpracy między studentami, szkołami i firmami oraz indywidualnego traktowania każdego ucznia. Aby proces nauczania i nabywania kompetencji był jak najbardziej efektywny i elastyczny, autorka na podstawie do- 
świadczeń z projektu BBVET proponuje wykorzystanie następujących elementów przy procesie projektowania i wdrażania nowoczesnego szkolnictwa zawodowego:

$\rightarrow$ nauczanie stacjonarne wzmocnione wirtualną platformą edukacyjną opartą na technologii informatycznej - dostęp niezależny od czasu, miejsca i szybkości nauki;

$\rightarrow$ indywidualne dopasowanie, które zapewnia optymalne efekty uczenia i w rezultacie daje wyniki znacznie lepsze niż przeciętne;

$\rightarrow$ coaching, indywidualne informacje zwrotne i plany działania, które zapewniają monitorowanie postępu w szkoleniu;

$\rightarrow$ rozwój umiejętności miękkich i dostosowanie do różnych rodzajów pracy w przedsiębiorstwach. 


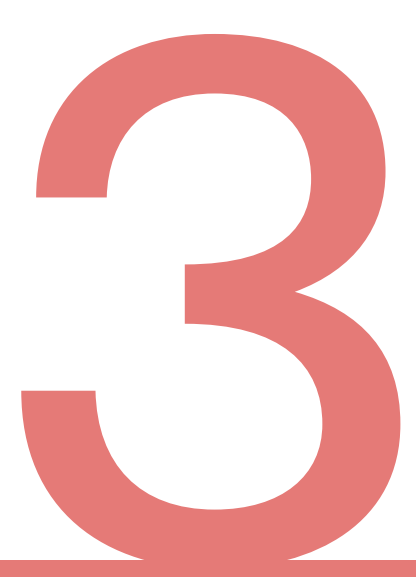


Wsparcie kreatywności

w szkole 


\section{Jak zaprojektować kreatywną lekcję?}

Marlena Plebańska

Niniejszy rozdział przedstawia charakterystykę realizacji kreatywnych zajęć dydaktycznych. Przedstawiono w nim cechy charakterystyczne kreatywnych zajęć dydaktycznych, innowacyjne metody i formy prowadzenia lekcji, a także propozycje planowania kreatywnych lekcji oraz korzyści wynikające z ich realizacji.

\section{Słowa kluczowe:}

kreatywność

kompetencje przyszłości

kreatywne lekcje 


\section{How to design a creative lesson?}

Marlena Plebańska

This article presents the characteristics of the implementation of creative didactic classes. The article presents the characteristics of creative didactic classes, innovative methods and forms of lessons. In addition, proposals for planning creative lessons and the benefits of their implementation have been presented.

Keywords:

creativity

future competences

creative lessons 


\section{Wprowadzenie}

Nie ma jednej ogólnie przyjętej definicji kreatywności, w literaturze można znaleźć ich kilkadziesiąt, ponieważ ten z pozoru prosty proces jest bardzo szeroko omawiany i przedstawiany z różnych perspektyw. Najogólniej możemy określić kreatywność jako zdolność tworzenia czegoś nowego, np. nowego rozwiązania, nowego produktu, nowego procesu, nowych pomysłów, niekonwencjonalnych idei czy koncepcji.

Kreatywność jako zdolność do tworzenia nowych rozwiązań charakteryzują cztery podstawowe cechy zdefiniowane przez National Advisory Committee on Creative and Cultural Education (NACCCE):

$\rightarrow$ kreatywność wymaga wykorzystania wyobraźni;

$\rightarrow$ kreatywne działanie jest działaniem celowym, skierowanym na osiągnięcie rezultatu;

$\rightarrow$ efektem kreatywnego działania jest oryginalne dzieło;

$\rightarrow$ efekt powinien być wartościowy z perspektywy założonych celów.

Jak widać, kreatywność jest zatem pojęciem subiektywnym, zależnym od wielu warunków brzegowych wyznaczających ramy kreatywności w danym kontekście. Zachowanie, produkt, idea zostaną uznane za kreatywne w wyniku subiektywnej oceny uprzednio określonych przez jednostkę lub instytucję warunków brzegowych kreatywności oraz celów stawianych przed danym kreatywnym rozwiązaniem.

Kreatywność od dziesięcioleci podlega wielu badaniom, również cechy i postawy osób kreatywnych zostały gruntownie przebadane. Kim zatem jest osoba kreatywna? Jan Fazlagić $(2018$, s. 1) definiuje następujące cechy osób kreatywnych:

$\rightarrow$ wykazują cechy płci przeciwnej- mężczyźni o cechach psychiki kobiecej, kobiety o cechach psychiki męskiej;

$\rightarrow$ są jednocześnie konserwatywne w poglądach i buntownicze;

$\rightarrow$ wykazują pasję wobec swojej pracy, a jednocześnie potrafią na nią spojrzeć z dystansu;

$\rightarrow$ cechują się introwertyzmem i ekstrawertyzmem - potrzebą samotności połączonej z potrzebą bycia wśród ludzi;

$\rightarrow$ wykazują skromność, a zarazem dumę - boleśnie odczuwają zaniżone poczucie własnej wartości i jednocześnie są bardzo pewne siebie;

$\rightarrow$ charakteryzują się zrównoważonym sposobem myślenia, w którym aktywność wykazuje zarówno prawa, jak i lewa półkula; 
$\rightarrow$ odznaczają się dużą dozą energii fizycznej naprzemiennie z silną potrzebą ciszy i spokoju;

$\rightarrow$ w ich zachowaniu obserwujemy wiele sprzeczności - połącznie mądrości i dziecinności.

Przedstawiony powyżej wykaz cech osób kreatywnych burzy wiele mitów związanych z kreatywnością, byciem kreatywnym, tworzeniem kreatywnych rozwiązań. Stawia również pytania: jak rozwijać kreatywność? Jak pomagać ludziom kreatywnym rozwijać się? Jak konstruować kreatywne zajęcia dydaktyczne i kreatywne lekcje? Czy dobór odpowiednich metod, form oraz narzędzi prowadzenia zajęć dydaktycznych wpłynie na kreatywność uczniów? Próbę odpowiedzi na te pytania stanowi niniejszy rozdział.

\section{Kogo potrzebuje współczesny świat?}

Żyjemy w czasach, w których w zasadzie jedyną stałością jest permanentna zmiana. Dotyczy ona każdego obszaru naszego codziennego życia. Postępująca robotyzacja i automatyzacja pracy zmienia katalog profesji i zawodów, w których już w niedalekiej przyszłości będziemy pracować. Ciągły rozwój każdego człowieka wpisany jest już na stałe w indywidualne ścieżki kariery niezależnie od wykonywanego zawodu, a tempo rozwoju zawodowego nieprzerwanie wzrasta. Jeszcze kilka lat temu wystarczający był systematyczny rozwój w ramach jednej profesji zgodny z koncepcją LLL (lifelong learning). Obecnie to za mało, współczesny człowiek coraz częściej będzie musiał zmieniać zawód kilka razy w ciągu swojego życia. Z kolei postępująca nowoczesność z jednej strony oraz zniszczenia planety, globalne ocieplenie, bieda i głód z drugiej wymuszają na współczesnym człowieku, by był kreatywny. Świat potrzebuje bowiem teraz ludzi twórczych, otwartych na zmianę, potrafiących aktywnie z niej korzystać w kontekście realizacji celów indywidualnych i grupowych. Współczesny świat potrzebuje ludzi przełamujących schematy i stereotypy, potrafiących myśleć w sposób niestandardowy, łączyć $w$ toku realizacji podejmowanych przez siebie działań wiedzę i umiejętności z różnych dziedzin. Współczesny świat potrzebuje ludzi kreatywnych potrafiących tworzyć nowe rozwiązania w każdym aspekcie życia. Kreatywność powinna być zatem rozwijana już od najmłodszych lat, w szkole, a nawet w przedszkolu. Powinna zostać na stałe wpisana w programy i scenariusze zajęć, a także $w$ działania i kompetencje nauczycieli. 


\section{Dlaczego lekcja powinna być kreatywna?}

Trudno wymienić wszystkich "wrogów” edukacji, a ich identyfikacja zależy w dużej mierze od roli i perspektywy osób rozpoznających ich w środowisku szkolnym. Z perspektywy ucznia jednymi z kluczowych wrogów edukacji są nuda i brak zaangażowania w proces dydaktyczny. Ich główną przyczynę stanowi niewłaściwy sposób prowadzenia lekcji, najczęściej jako lekcji podawczych skoncentrowanych na przekazaniu wiedzy, a nie na rozwoju indywidualnych talentów uczniów. Edukacja, aby odpowiedzieć na potrzeby zmieniającego się świata, wymaga znaczących zmian praktycznie w każdym jej aspekcie. Jedną z kluczowych modyfikacji jest zmiana form, metod i narzędzi prowadzenia zajęć dydaktycznych, tak aby odpowiadały one potrzebom kształcenia kompetencji przyszłości. Lekcja przygotowująca współczesnego ucznia do życia w realnym społeczeństwie to lekcja dająca mu przestrzeń do poznawania i eksperymentowania, zdobywania twórczych doświadczeń, poszukiwania i rozwijania własnych talentów. Zajęcia ukierunkowane na rozwój szeroko rozumianej kreatywności to droga do wyposażenia uczniów w kompetencje, które pozwolą im nie tylko na aktywne funkcjonowanie w zmianie, ale też na aktywne kreowanie zmiany w każdym aspekcie ich dorosłego życia.

\section{Plan kreatywnej lekcji}

Bardzo trudno jednoznacznie zdefiniować, czym jest kreatywna lekcja. Czy jest to lekcja prowadzona w taki sposób, aby kształcić kompetencje przyszłości, czy może, aby pobudzić kreatywność uczniów? Czy raczej jest to lekcja prowadzona w kreatywny sposób przez kreatywnych nauczycieli? W zasadzie każda z przedstawionych powyżej propozycji wydaje się słuszna, a wariantów kreatywnych lekcji istnieje dużo więcej. Kiedy mówimy o kreatywnej lekcji, definiujemy ją bardzo różnie. Określenie jej jednoznacznego przebiegu, stałego procesu czy cyklu nie jest możliwe, ponieważ nie sposób jednoznacznie określić jej następujących parametrów:

$\rightarrow$ cele kreatywnej lekcji - określane indywidualnie dla każdej lekcji;

$\rightarrow$ metody dydaktyczne - wybierane indywidualnie dla każdej kreatywnej lekcji w kontekście uprzednio ustalonych celów lekcji;

$\rightarrow$ narzędzia pracy-wykorzystywane do przeprowadzenia kreatywnej lekcji, wyznaczane indywidualnie w kontekście indywidualnych celów i metod przyjętych dla danej kreatywnej lekcji; 
$\rightarrow$ wybór przestrzeni dydaktycznej, w której odbywa się kreatywna lekcja - adaptowana osobno dla każdej lekcji prowadzonej w ramach zajęć szkolnych lub przestrzeń pozaszkolna, np. park, muzeum, centrum handlowe etc. dobrane do potrzeb kreatywnej lekcji;

$\rightarrow$ czas realizacji kreatywnej lekcji - każdorazowo obliczany w zależności od celu; kreatywna lekcja może trwać przyjęte 45 minut lub dowolną wielokrotność tego czasu; może też odbywać się w trybie ciągłym lub stanowić cykl zajęć;

$\rightarrow$ podział na etapy kreatywnej lekcji, który przyjmować może różne formy; do najczęściej definiowanych należą:

$\rightarrow$ etap przygotowawczy, etap realizacji, etap podsumowania;

$\rightarrow$ etap organizacyjny, etap przygotowawczy, etap realizacji, etap podsumowania.

Rysunek 1. przedstawia przykładowy podział kreatywnej lekcji na etapy.

Rysunek 1. Podział kreatywnej lekcji na etapy

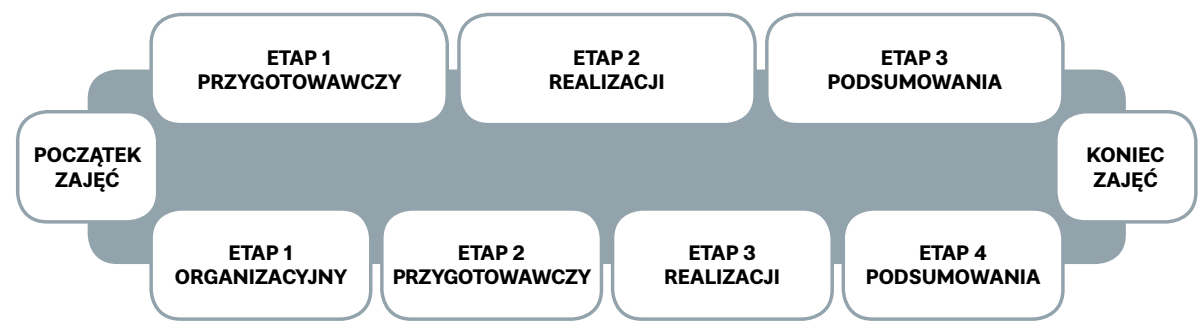

Źródło: opracowanie własne.

Przedstawiony podział kreatywnej lekcji to tylko najczęściej wybierany sposób realizacji kreatywnych zajęć. Mogą one przebiegać w innych, dowolnych etapach, które zależą od autorskiego pomysłu nauczyciela. Są one definiowane dla każdej kreatywnej lekcji oddzielnie, bowiem każda z nich ma przebieg indywidualny, wynikający ze specyfiki przedstawionych parametrów, które należy uwzględnić, a w szczególności celów dydaktycznych lekcji. 
Jednak niezależnie od liczby etapów, na które zostanie podzielona lekcja, podczas przygotowywania, a potem prowadzenia zajęć definiuje się te same trzy podstawowe elementy każdego etapu: cele etapu, zadania dla danego etapu oraz oczekiwane efekty każdego z nich.

Podstawowe elementy każdego etapu kreatywnej lekcji definiuje się następująco:

$\rightarrow$ cele etapu - określenie celów danego etapu lekcji;

$\rightarrow$ zadania etapu - określenie zadań danego etapu oraz sposobu ich realizacji;

$\rightarrow$ efekty - określenie oczekiwanych efektów danego etapu.

Niezależnie od ostatecznego podziału kreatywnej lekcji na etapy i elementy etapów wspólna jest konieczność zdefiniowania brzegowych parametrów i składowych dla kreatywnej lekcji. Brak definicji tych parametrów i składowych może spowodować, że kreatywna lekcja nie będzie tak efektywna, jak mogłaby być w wybranych obszarach, lub nie zrealizuje przyjętych celów całościowo. Sprecyzowanie dokładnych działań na każdym etapie, dokładny oraz celowy dobór metod i narzędzi spowodują, że zadania realizowane na każdym z etapów kreatywnej lekcji będą prowadziły do uzyskania założonych efektów dydaktycznych. Dlatego też, aby zapewnić zaplanowanie wszystkich kluczowych parametrów i składowych lekcji, warto opisać kreatywną lekcję choćby w sposób uproszczony, porządkujący najważniejsze zagadnienia związane z planowaniem, realizacją i ewaluacją cyfrowej lekcji, takie jak:

$\rightarrow$ definicja,

$\rightarrow$ cele,

$\rightarrow$ przewidywany czas realizacji,

$\rightarrow$ kreatywne metody dydaktyczne,

$\rightarrow$ narzędzia dydaktyczne,

$\rightarrow$ przestrzeń dydaktyczna,

$\rightarrow$ niezbędne kompetencje nauczycieli,

$\rightarrow$ konieczne wejściowe kompetencje uczniów.

Zastosowanie opisu kreatywnej lekcji przyczyni się do zapewnienia jej właściwej organizacji oraz do efektywnej realizacji procesu dydaktycznego w ramach prowadzenia twórczych działań podczas kreatywnej lekcji. Jeżeli jednak autorzy kreatywnych lekcji chcieliby stworzyć 
ich kompletny opis, wówczas warto rozważyć stworzenie scenariusza kreatywnej lekcji.

\section{Scenariusz kreatywnej lekcji}

Podobnie jak w przypadku samego zdefiniowania kreatywnej lekcji, nie istnieje gotowy model opracowywania scenariuszy kreatywnej lekcji. Scenariusze kreatywnych lekcji, podobnie jak same kreatywne lekcje, przybierają bardzo różnorodne postacie i są zapisywane w rozmaitych formach. Bardzo istotne pozostaje jednak opracowanie scenariusza kreatywnej lekcji tak, aby opisywał jej podstawowe założenia brzegowe. Do głównych z nich możemy zaliczyć:

$\rightarrow$ tytuł zajęć - wskazujący na treści merytoryczne lekcji,

$\rightarrow$ cele lekcji-główne i szczegółowe cele lekcji,

$\rightarrow$ poziom edukacyjny zajęć - określenie poziomu edukacyjnego uczniów, dla których przeznaczona jest lekcja,

$\rightarrow$ specyfika grupy docelowej-określenie kompetencji wejściowych uczniów, którzy będą uczestniczyć w danej lekcji,

$\rightarrow$ zakres merytoryczny - określenie zakresu merytorycznego zajęć,

$\rightarrow$ założenia czasowe - określenie ramy czasowej zajęć i czasu realizacji poszczególnych etapów lekcji,

$\rightarrow$ wykorzystywane metody i narzędzia realizacji zajęć - określenie metod i narzędzi realizacji lekcji,

$\rightarrow$ wykorzystywane zasoby edukacyjne - określenie niezbędnych zasobów edukacyjnych wykorzystywanych w toku lekcji,

$\rightarrow$ przebieg zajęć - określenie przebiegu realizacji zajęć ze szczególnym uwzględnieniem przyjętych kreatywnych metod pracy,

$\rightarrow$ ewaluacja zajęć - określenie sposobu oraz narzędzi ewaluacji zajęć.

Realizując scenariusz kreatywnej lekcji, można skorzystać z gotowych wzorców scenariusza kreatywnej lekcji lub zaprojektować swój własny. Coraz częściej szkoły projektują autorskie scenariusze zajęć, które oczywiście podlegają modyfikacji i są stale rozwijane. Nauczyciele, korzystając z jednolitego scenariusza kreatywnych lekcji na poziomie szkoły, tworzą bazę wiedzy scenariuszy zarówno przedmiotowych, jak i interdyscyplinarnych. Na rysunku 2 zaprezentowano sześć podstawowych kroków realizacji scenariusza kreatywnej lekcji. 
Rysunek 2. Sześć kroków realizacji scenariusza kreatywnej lekcji

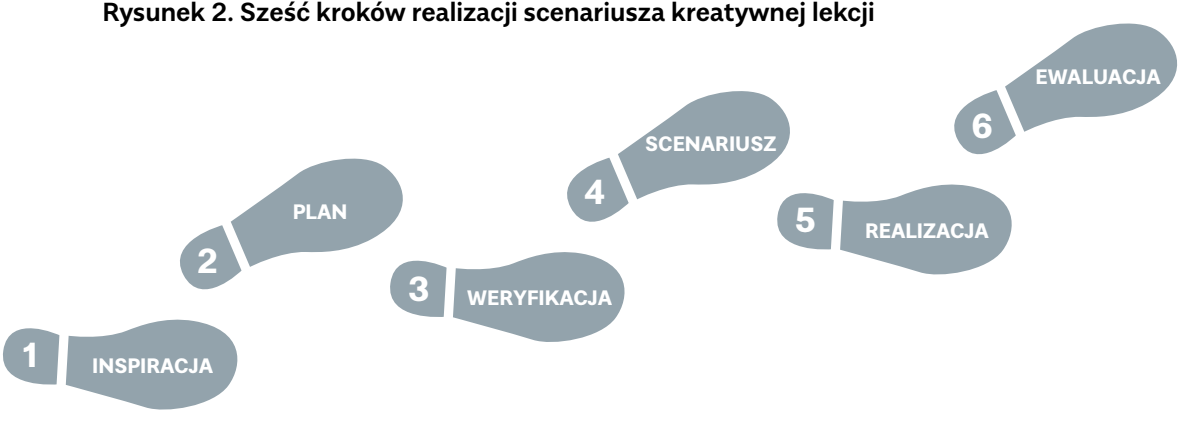

Źródło: opracowanie własne.

1. Inspiracja - etap zbierania inspiracji, doświadczeń, pomysłów na projekt autorskich zajęć. Do najczęściej realizowanych aktywności na tym etapie należą: udział w otwartych kreatywnych lekcjach realizowanych przez doświadczone placówki, udział w warsztatach i szkoleniach przygotowujących do pracy z wykorzystaniem kreatywnych metod pracy oraz z wykorzystaniem narzędzi edukacyjnych ukierunkowanych na kreatywność, dzielenie się doświadczeniami z osobami mającymi praktykę w realizacji kreatywnych zajęć. Często pomysł na kreatywną lekcję rodzi się przypadkiem, na marginesie innych działań dydaktycznych.

2. Plan - etap precyzowania pomysłu na kreatywną lekcję, określania zakresu merytorycznego lekcji oraz metod i narzędzi realizacji lekcji. Określa się cele dydaktyczne lekcji, które determinują metody i narzędzia wykorzystane podczas lekcji.

3. Weryfikacja - etap weryfikacji pomysłu na kreatywną lekcję. Analizuje się możliwości wdrożenia pomysłu oraz związane z jego realizacją zarówno szanse, jak i zagrożenia przeprowadzenia kreatywnej lekcji.

4. Scenariusz - etap opracowywania scenariusza, kiedy określa się dokładny zakres działań dydaktycznych, które będą prowadzone w ramach kreatywnej lekcji, ze szczególnym uwzględnieniem kreatywnych form pracy. Scenariusze kreatywnych lekcji bardzo często są opracowywane przez grono osób. W przypadku realizacji scenariuszy przez osoby indywidualne scenariusze bardzo często poddaje się pod dyskusję w szerszym gronie lub ocenie koleżeńskiej.

5. Realizacja - etap pierwszego wdrożenia zajęć kreatywnych, pierwszej realizacji zajęć z uczniami, kiedy najczęściej pojawiają się jeszcze 
kwestie wymagające dopracowania lub zmiany. Zwykle po pierwszej realizacji zajęć modyfikowane są kwestie wymagające korekt, tak aby ostateczny kształt zajęć przyjął postać pozbawioną błędów.

6. Ewaluacja - etap ewaluacji efektywności dydaktycznej kreatywnej lekcji.

\section{Kreatywne metody pracy wykorzystywane w ramach kreatywnych lekcji}

Scenariusz realizacji kreatywnej lekcji powinien uwzględniać wykorzystanie kreatywnych metod pracy oraz kreatywnej pracy zespołowej. Istnieje wiele nowoczesnych, innowacyjnych metod nauczania, którymi można posłużyć się w celu rozwijania u uczniów kreatywności oraz budowania kompetencji przyszłości, wśród których kreatywność jest jedną z kluczowych. Do najbardziej innowacyjnych metod pracy stawiających zarówno na samo stymulowanie kreatywności, jak i na pracę projektową oraz kształcenie kompetencji przyszłości, możemy zaliczyć:

$\rightarrow$ STEAM,

$\rightarrow$ EduSCRUM,

$\rightarrow$ Design thinking.

\section{STEAM}

STEAM jako metoda uczenia się i nauczania skupia się na zaspokojeniu potrzeb gospodarki XXI w. przez rozwijanie kompetencji przyszłości. STEAM stawia na naukę projektową konsolidującą pięć kluczowych bloków tematycznych: naukę, technologię, inżynierię, sztukę i matematykę. Koncepcja ta jest ukierunkowana na kształcenie uczniów, którzy dzięki realizacji projektów potrafią myśleć w sposób innowacyjny i niekonwencjonalny, podejmują rozważne ryzyko, angażują się w eksperymentalne uczenie się i twórcze rozwiązywanie problemów, a także są chętni do współpracy i aktywnie uczestniczą w procesach twórczych. Filozofia STEAM odzwierciedla koncepcję:

STEAM to idea edukacyjna stworzona w Rhode Island School of Design, która dodała sztukę do wcześniejszej koncepcji STEM. Według tej koncepcji „celem jest wspieranie prawdziwych innowacji łączących 
myślenie naukowca lub technologa z koncepcją artysty lub projektanta". STEAM to naturalne procesy twórcze i poznawcze, angażujące $w$ proces uczenia się wszelkie możliwości ucznia i wszystkie obszary jego mózgu. Tak więc dopiero model STEAM daje możliwość pełnego wykorzystania potencjału uczniów i kształtowania kompetencji przyszłości. STEAM zapewnia możliwość kompleksowego wykształcenia u uczniów szeroko rozumianej przedsiębiorczości i postaw przedsiębiorczych dzięki realizacji następujących postulatów:

$\rightarrow$ STEAM uczy młodych ludzi, w jaki sposób aktywnie zmieniać świat oraz kreować otaczającą nas rzeczywistość, zarówno w życiu prywatnym, jak i społecznym.

$\rightarrow$ STEAM stawia na innowacyjność i kreatywność jako kluczowe wartości, które powinny być rozwijane u każdego pracownika.

$\rightarrow$ STEAM daje uczniom możliwość eksperymentowania i podejmowania twórczego ryzyka na rzecz realizacji innowacyjnych rozwiązań.

$\rightarrow$ STEAM stawia na pracę projektową, w której kluczową rolę odgrywa zespół samozarządzających się uczniów działających w myśl zasad zwinnego zarządzania projektami Agile (Super TEAM), planowania przedsięwzięć projektowych i prowadzenia ich dla osiągnięcia zamierzonych celów.

$\rightarrow$ STEAM to indywidualny rozwój każdego z uczniów poprzez realizacje grupowych projektów ukierunkowanych na rozwój świata oraz umiejętność oceny i identyfikacji własnych mocnych i słabych stron.

$\rightarrow$ STEAM kształtuje postawę przedsiębiorczą. Charakteryzuje się ona inicjatywnością, aktywnością, niezależnością i innowacyjnością w życiu osobistym, społecznym, w tym zawodowym.

$\rightarrow$ STEAM stawia na motywację i determinację $w$ realizowaniu celów osobistych i wspólnych, zarówno prywatnych, jak i społecznych.

$\rightarrow$ STEAM pozwala wybrać te treści, których opłaca się uczyć, oraz weryfikować ich wartość.

$\rightarrow$ STEAM to holistyczny rozwój każdego człowieka sprawdzający się równie dobrze w kształceniu przedszkolaków, jak i seniorów (oraz wszystkich grup pomiędzy).

$\rightarrow$ STEAM pozwala uczniom stać się autorami własnego procesu edukacyjnego, a nie jego biernymi konsumentami, dzięki czemu kreuje się postawy przedsiębiorcze. 
W edukacji skoncentrowanej na kształcenie kompetencji przyszłości potrzebujemy odzwierciedlenia naturalnych procesów poznawczych. Potrzebujemy "otwarcia drzwi" do prawdziwego świata i uwzględnienia naturalnych zasad poznawania w cyklach nauczania i uczenia się. STEAM jest jedną z metod przygotowujących uczniów do nowych realiów rynku pracy.

Koncepcja STEAM stanowi jedną z najwyżej cenionych metod edukacyjnych wprowadzanych do systemów oświaty w wielu krajach świata. Metoda STEAM stawia ucznia w roli badacza, odkrywcy, projektanta i wykonawcy, który wykorzystuje naukę, technologię, inżynierię, sztukę i matematykę do tworzenia własnych rozwiązań, projektów i innowacji. W modelu STEAM uczniowie pracują twórczo, podejmują ryzyko, angażują się w eksperymentalne uczenie się, rozwiązują problemy i współpracują w atmosferze, która zezwala na popełnianie błędów i zachęca do uczenia się na ich podstawie. Nauka w modelu STEAM to rozwijanie indywidualnych talentów każdego z uczniów oraz jednoczesny rozwój kompetencji społecznych, kompetencji cyfrowych i szeroko rozumianych postaw przedsiębiorczych (Plebańska, Trojańska 2018). STEAM sprawdza się w nauczaniu na każdym poziomie edukacyjnym i stanowi doskonały sposób kształcenia niezależnie od tego, jaki zawód w przyszłości wybiorą uczniowie. STEAM rozwija postawy przedsiębiorcze, uczy krytycznego myślenia, rozwiązywania problemów i wielu innych umiejętności, które mogą być używane przez całe życie, niezależnie od profesji, jaką się wykonuje. STEAM to również koncepcja, która pomaga pobudzić kreatywność, rozszerza perspektywę postrzegania świata. STEAM to wreszcie sprawdzona metoda rozwoju osób pracujących nad innowacyjnymi projektami, nowymi produktami i usługami (Plebańska, Trojańska 2018).

\section{Design thinking}

Design thinking to metoda tworzenia innowacyjnych produktów i usług na podstawie dobrze zrozumianych oczekiwań użytkowników. Główne założenia Design thinking to:

$\rightarrow$ koncentracja na użytkowniku - zrozumienie jego uświadomionych i nieuświadomionych potrzeb;

$\rightarrow$ interdyscyplinarny zespół - spojrzenie na problem z wielu perspektyw;

$\rightarrow$ eksperymentowanie i częste testowanie hipotez - budowanie prototypów i zbieranie feedbacku od użytkowników. 
W efekcie zastosowania Design thinking powstają rozwiązania, które:

$\rightarrow$ odpowiadają stawianym celom i potrzebom użytkowników;

$\rightarrow$ są technologicznie wykonalne;

$\rightarrow$ są ekonomicznie uzasadnione.

Design thinking to usystematyzowane podejście do procesu innowacji bardzo powszechnie stosowane w biznesie, lecz równie efektywnie wykorzystywane w edukacji. Pierwszym krokiem we wdrażaniu Design thinking jest zbudowanie interdyscyplinarnego zespołu, w skład którego wchodzą specjaliści z różnych branż, np. inżynierowie, technolodzy, specjaliści od marketingu czy projektowania, socjolodzy etc. W przypadku projektów edukacyjnych podczas budowania interdyscyplinarnego zespołu uczniowie muszą mieć możliwość włączenia do niego osób biegłych w różnych dziedzinach, o zróżnicowanych talentach i zainteresowaniach. $W$ takim zespole uczniowie będą $w$ stanie wszechstronnie i wielopłaszczyznowo przeanalizować problem projektowy.

Następnie powołany zespół realizuje, krok po kroku, kolejne etapy projektu:

$\rightarrow$ empatyzacja,

$\rightarrow$ definiowanie problemu (określenie głównych wytycznych projektowych, analiza danych niezbędnych do zdefiniowania projektu),

$\rightarrow$ tworzenie koncepcji projektu (burza mózgów w zespole projektowym),

$\rightarrow$ modelowanie, prototypowanie rozwiązania,

$\rightarrow$ testy i ewaluacja prototypu,

$\rightarrow$ publikacja i produkcja projektu.

Posługując się zestawem narzędzi i technik Design thinking, pracuje się w taki sposób, aby wypracować rozwiązanie możliwe do wdrożenia. Celem każdego zespołu niezależnie od tematyki projektu jest wygenerowanie innowacyjnego rozwiązania oraz sprawdzenie jego działania na etapie prototypowania. Ścieżka prowadząca przez kolejne etapy nie musi być liniowa. Porażka poniesiona na etapie prototypowania może wymagać powrotu do etapu generowania pomysłów albo nawet definiowania problemu i rozpoczęcia procesu od początku. Design thinking to metoda, która pozwala na popełnianie błędów, stanowią one naturalną część realizacji projektu. To właśnie dzięki analizie błędów, które pojawiły się w projekcie na etapie prototypu, oraz ich stałej modyfikacji dochodzimy do realizacji pożądanego rozwiązania (Plebańska, Trojańska 2018). 


\section{EduSCRUM}

EduSCRUM to idea zaczerpnięta ze świata IT, gdzie SCRUM, wywodzący się z nurtu Agile (zwinne zarządzanie projektami), stanowi zbiór praktyk wprowadzających w środowisko biznesowe wartości takie jak zaangażowanie, odwaga, skupienie, otwartość i poszanowanie. Opiera się on na trzech głównych filarach:

$\rightarrow$ przejrzystość (widoczność wszystkich aspektów danego procesu),

$\rightarrow$ inspekcja (weryfikowanie działania, jego rezultatów),

$\rightarrow$ adaptacja (korekta ewentualnych błędów).

EduSCRUM do świata edukacji został wprowadzony przez Willy'ego Wijnandsa, wieloletniego nauczyciela chemii i fizyki z Holandii. Wijnands, zainspirowany praktyką SCRUM na całym świecie, zaimplementował ją na swoich zajęciach. EduSCRUM to praktyczna i przejrzysta metoda pracy projektowej. Nauczyciel, rozpoczynając projekt, w sposób jasny i zrozumiały dla uczniów przedstawia cele projektowe. Następnie uczniowie samodzielnie, w grupie oraz indywidualnie, sprawdzają, jakie są ich postępy, czego potrzebują do lepszego uczenia się, a co jest im zbędne na danym etapie i co im przeszkadza. Na proces składa się sześć praktyk:

$\rightarrow$ tworzenie zespołu (Team Formation),

$\rightarrow$ planowanie działania (Sprint Planning),

$\rightarrow$ wspólne uzgodnienia (Stand-up),

$\rightarrow$ przegląd działania (Sprint Review),

$\rightarrow$ wgląd w działanie (Retrospective),

$\rightarrow$ wnioski osobiste (Personal Reflection).

W EduSCRUM nauczyciel jest facylitatorem procesu, wspiera swoich uczniów, przestaje być osobą, która przekazuje wiedzę, a staje się partnerem dla ucznia w jej poszukiwaniu. Cały proces uczy skutecznej komunikacji oraz odpowiedzialności za uczenie się. EduSCRUM stanowi wspaniałe narzędzie do pracy z uczniami w każdym wieku, daje nauczycielowi i uczniom dużo wolności, przy równoczesnym zachowaniu uważności na realizowanie programu. Willy Wijnands oraz wielu innych nauczycieli w Europie i poza nią zauważyli, jak wiele EduSCRUM wniósł do ich praktyki, pozwolił zminimalizować czas poświęcony na realizowanie podstawy programowej, wprowadził do szkoły nową kulturę komunikacji, ograniczył czas poświęcony na prace domowe, których 
nie zadaje już nauczyciel, tylko sam uczeń, jeśli czuje, że jest mu potrzebna. EduSCRUM jest zatem doskonałą metodą pracy projektowej w projektach STEAM (Orbitowska 2018).

\section{Podsumowanie - efekty kreatywnych lekcji}

Kreatywne zajęcia często kojarzą się z chaosem, serią działań podejmowanych ad hoc. W rzeczywistości jednak wymagają przemyślanego planu i określonej struktury, która zapewni osiągnięcie założonych celów dydaktycznych. Oczywiście dynamika pracy grupy oraz sam przebieg zajęć determinują nieprzewidziane zmiany, na które każdy nauczyciel powinien być gotowy, jednak to w celowym wykorzystaniu kreatywnych metod i dobrym pomyśle na zajęcia tkwi efektywność lekcji. Kreatywne lekcje cechują się indywidualnym podejściem do uczniów, za każdym razem odmienną strukturą i dynamiką pracy dostosowaną do potrzeb grupy. Kreatywne lekcje to dla uczniów pole do eksperymentowania, które pozwala im na:

$\rightarrow$ zdobywanie kompetencji przyszłości,

$\rightarrow$ poszukiwanie i rozwijanie indywidualnych talentów,

$\rightarrow$ sprawdzanie się w nowych rolach,

$\rightarrow$ współuczestnictwo w innowacyjnych projektach

i wiele innych.

Kreatywne lekcje to pole budowania szeroko rozumianej kreatywności, rozwijanie umiejętności wykorzystywania wyobraźni, ukierunkowanie na celowe działania kreatywne, twórcza realizacja innowacji. 



\section{Ocena kreatywności uczniów \\ - wyzwanie dla systemu edukacji}

Jan Fazlagić

Wyzwania pojawiające się na rynku pracy i w społeczeństwie w XXI w. wymagają czegoś więcej niż tylko poszerzania u uczniów umiejętności językowych i matematycznych. Na czoło wysuwa się szczególnie rozwijanie kreatywności jako tej kompetencji, którą będzie bardzo trudno zastąpić sztuczną inteligencją. Rozwój kreatywności u uczniów powinien służyć praktycznym celom związanym z przygotowywaniem ludzi do rozwiązywania nietypowych problemów, radzenia sobie z wieloznacznością, odpowiedzialnego podejmowania ryzyka. Dla zapewnienia przejrzystości i odpowiedzialności systemu edukacji od lat stosuje się w szkołach egzaminy i inne formy walidacji postępów w nauczaniu. Te obowiązujące aktualnie podejścia nie sprzyjają rozwijaniu kreatywności u uczniów - kreatywność jest cechą ucznia niedostrzeganą, "ślepą" dla systemu edukacji. Nowy system nauczania powinien znacznie więcej uwagi niż obecnie poświęcić rozwojowi sposobów i technik oceny kreatywności, aby uczniowie otrzymywali rzetelną informację zwrotną na temat swoich umiejętności w tym obszarze. Aby tak się stało, powinniśmy rozwijać i wdrażać nowe metody egzaminowania uczniów nastawione na ocenę ich kreatywności.

\section{Słowa kluczowe: \\ kreatywność \\ system edukacji \\ egzaminy




\section{Assessment of students' creativity \\ - a challenge for education systems}

Jan Fazlagić

The educational challenges for the $21^{\text {st }}$ Century go beyond the need for the development of communication skills and STEM programmes. In specific, creativity looms as a competence which is crucial due to the fact that it is very difficult to substitute it with Artificial Intelligence. The development of students' creativity should prepare them for solving practical; non-standard and ambiguous problems, responsible risk-taking and similar ill-defined, fuzzy problems. In order to ensure transparency and accountability examinations, other forms of validation of learning outcomes have to be implemented in schools. The current approaches to examinations do not support the development of creativity among students - creativity as a personal trait of a student is overlooked and the system of education is literally "blind" to it. A new system of education fit for the requirements of the $21^{\text {st }}$ century should provide students with hands-on and reliable feedback on their creativity skills. In order to achieve that goal new methods of examining should be implemented and adopted.

\section{Keywords:}




\section{Wprowadzenie}

Systemy edukacji na świecie są teraz powszechnie krytykowane z powodu zbytniego przywiązania do egzaminów lub niemal ich "kultu" (OECD 2013; Fazlagić 2018b). Powszechna w latach 90. XX w. chęć sparametryzowania, "opomiarowania" wszystkich aspektów naszego życia, w szczególności funkcjonowania sektora publicznego, sprawiła, że do głównego nurtu (mainstreaming) polityk edukacyjnych wprowadzono na szeroką skalę egzaminy zewnętrzne. Obecnie systemy oświaty, nie tylko w Polsce, ale także w wielu innych krajach świata, stoją przed wieloma nowymi wyzwaniami. Oprócz problemu zmian klimatycznych akcentuje się brak dostatecznego nacisku na rozwój kompetencji proinnowacyjnych (OECD 2018). Emanacją tej sytuacji jest zjawisko "uczenia się pod test". W efekcie uczniowie nie rozwijają się $\mathrm{w}$ dostatecznym stopniu pod względem intelektualnym i emocjonalnym w zakresie m.in. krytycznego myślenia, wykorzystywania wyobraźni, zdolności do oceny etycznej własnych czynów, wytrwałości czy wreszcie kreatywności. W dalszej części niniejszego rozdziału zostanie przedstawiona pogłębiona analiza tego zjawiska oraz zostaną zaproponowane pewne rozwiązania i postulaty. Głównym celem niniejszego opracowania jest:

$\rightarrow$ Zwrócenie uwagi na to, że odpowiednio zaprojektowany system edukacji, przy uwzględnieniu jego wielkości (w warunkach polskich: kilkaset tysięcy nauczycieli, kilka milionów uczniów, tysiące szkół i placówek oświatowych itd.), może i powinien promować rozwój kreatywności u uczniów, m.in. poprzez zmodyfikowanie metod oceniania wyników nauczania.

$\rightarrow$ Zaproponowanie rozwiązań, które mogą zainspirować i wskazać kierunki zmian w podejściu do oceny postępów w nauce.

\section{Argumenty przemawiające za potrzebą zmiany akcentów w systemie oświaty}

Tradycyjna szkoła, która wyłoniła się na początku XIX w., powstała u progu ery industrialnej i miała służyć wdrożeniu niepiśmiennych obywateli w szybko rozwijających się społeczeństwach zachodnich do służby w wojsku i rozwijającym się przemyśle, a także w aparacie urzędniczym. Wówczas pruski model szkoły doskonale spełniał swoje zadanie transformacji społeczeństwa agrarnego w społeczeństwo industrialne. 
Obecnie, w XXI w., model ten jest jednak uznawany za hamulec na drodze do transformacji społeczeństwa industrialnego w społeczeństwo postindustrialne, szczególnie w krajach próbujących zniwelować lukę cywilizacyjną wobec Zachodu, takich jak np. Polska (Fazlagić 2015).

Zmiany w otoczeniu społeczno-gospodarczym sprawiają, że podstawowa cecha psychospołeczna człowieka, jaką jest inteligencja (mierzona m.in. za pomocą testów IQ), może utracić swoją dominującą rolę jako wyznacznik „przewagi konkurencyjnej” jednostki na rynku pracy. W XXI w. nadrzędną rolę w ocenie kompetencji, a także "selekcji pozytywnej" w systemie edukacji powinna odgrywać nie inteligencja ucznia (jak jest teraz, w szczególności jeden z jej elementów, tzn. dobra pamięć), lecz jego kreatywność. Wbrew pozorom taka reorientacja wcale nie musi pociągać za sobą rewolucyjnych zmian.

W literaturze można znaleźć wiele czynników warunkujących, zdaniem licznych badaczy, kreatywność człowieka, poziom inteligencji jest tylko jednym z nich (Nęcka 2012; Szmidt 2013). Wynika to z faktu, że kreatywność i inteligencja są ze sobą silnie skorelowane, lecz tylko do pewnego poziomu wartości współczynnika inteligencji IQ - poziom ten jest łączony w psychologii z tzw. hipotezą progu (threshold hypothesis). Zgodnie z nią w populacji osób o współczynniku IQ powyżej 120 będzie można zidentyfikować zarówno osoby o przeciętnie wysokiej (aczkolwiek nie niskiej) kreatywności, jak i wybitnie kreatywne jednostki. Wyzwaniem dla systemu edukacji jest więc zadbanie nie tyle o uczniów mniej inteligentnych (czyli dostrzeżenie ich, dowartościowanie, zapewnienie im wsparcia), co o tych, u których współczynnik inteligencji plasuje się powyżej progu $(I Q=120)$ i którzy nie są wybitnie uzdolnieni, jeśli chodzi o perspektywę inteligencji ogólnej. Tacy uczniowie dla wielu nauczycieli kierujących się klasycznymi kryteriami oceny "zdolności" ucznia będą "przeciętni”, ale nie wybitni. To właśnie ta grupa uczniów jest najbardziej niedoceniana w systemie edukacji, jeśli chodzi o wyniki, które uzyskuje w nauczaniu, vs. jej niewykorzystany/ nieoceniany potencjał intelektualno-emocjonalny. Wizerunek osoby wybitnie inteligentnej budzi pozytywne konotacje, które są wzmacniane przez proces edukacji w szkole. Jedną ze zmian, jakie można by wprowadzić w systemie edukacji w XXI w., mogłaby więc być afirmacja uczniów ("bohaterów”) kreatywnych w życiu szkolnym jako modeli-roli dla społeczności szkolnej (Kim 2005; Preckel i in. 2006; Silvia 2008; Karwowski, Gralewski, 2013; Benedyk i in. 2014). 
Rozwój gospodarczy w XXI w. w większym stopniu niż w poprzednich okresach będzie opierał się na wiedzy, innowacjach i przemysłach kreatywnych. Mimo dużego znaczenia bazy przemysłowej wXXI w. producenci produktów materialnych, takich jak samochody, samoloty, komputery, meble, dużo częściej niż w przeszłości będą korzystać z "miękkich" elementów uzyskiwania przewagi konkurencyjnej - utalentowanych pracowników, wzornictwa przemysłowego i innowacji marketingowych. Ponadto rozwój sztucznej inteligencji sprawi, że zapotrzebowanie na umiejętności wyższego rzędu, do których odnoszą się kompetencje przekrojowe, będzie rosło. W związku z tym w najbliższych latach większego znaczenia nabiorą kompetencje personalne i społeczne. Wynika to $z$ jednej strony ze zmian w stylu życia i środowiska, w jakim wychowuje się obecnie młodzież (mniej okazji do doskonalenia kompetencji personalnych i społecznych niż w przeszłości), a z drugiej ze zmian na rynku pracy. Kompetencje miękkie i interpersonalne są tym obszarem kształcenia, na którego deficyty pracodawcy w Polsce i na świecie wskazują najsilniej (Word Bank Group 2019). Wraz z postulatami wysuwanymi wobec systemu oświaty odnośnie do podniesienia jakości kształcenia kompetencji personalnych i społecznych pojawia się potrzeba opracowania metod ich obiektywnej oceny. Skuteczny system egzaminowania sprawdzający poziom kreatywności i kreatywnego potencjału ucznia powinien nie tylko pełnić funkcję sygnalizującą pracodawcom zdolności, umiejętności i możliwości absolwentów (na podstawie wyników egzaminów), lecz także dawać samym uczniom wskazówkę co do tego, jakie są oczekiwania pracodawców i w konsekwencji - jak je spełnić.

Według Raportu OECD (2016) stoimy przed nową rewolucją przemysłową, której materializacją będą m.in. druk 3D (produkcja przyrostowa, internet rzeczy i wykorzystanie robotów). W przemyśle stosowane będą nowe materiały m.in. (z użyciem nanotechnologii) oraz nowe procesy produkcji. Nowe technologie będą miały wpływ na produkcję i dystrybucję towarów i usług. Przemysł 4.0 (Industry 4.0) to zbiorcze pojęcie oznaczające integrację inteligentnych maszyn, systemów oraz wprowadzanie zmian w procesach produkcyjnych mających w celu zwiększanie wydajności wytwarzania oraz wprowadzenie możliwości elastycznych zmian asortymentu. Przemysł 4.0 dotyczy nie tylko technologii, ale też nowych sposobów pracy i nowych funkcji 
pełnionych przez pracowników w przemyśle (Piątek 2017). Będzie rosło znaczenie umiejętności interdyscyplinarnych (OECD 2016).

Analitycy brytyjskiego pisma "The Guardian" zidentyfikowali pięć kluczowych, rewolucyjnych zmian, jakie zajdą na rynku pracy w przyszłości (Five ways... 2017). Pierwszą z nich będzie stopniowe zanikanie sztywnych struktur organizacyjnych - w XXI w. przedsiębiorstwa nie będą ich potrzebowały. Według niektórych badań w ciągu ostatniego ćwierćwiecza przedsiębiorstwa na świecie „spłaszczyły się" o ok. $25 \%$. Zniknęło kilka warstw struktury organizacyjnej. W ich miejsce powstały struktury sieciowe. $Z$ tego też powodu zmienia się kształt ścieżek kariery. Ścieżka kariery przyszłości będzie miała kształt zygzakowaty. Drugim ważnym czynnikiem, który wpłynie na zmiany na rynku pracy, jest rozwój sztucznej inteligencji. W samych Stanach Zjednoczonych szacuje się, że $45 \%$ wszystkich stanowisk pracy będzie w latach 2015-2035 zagrożonych przez możliwość ich automatyzacji (Five ways... 2017). W tym samym okresie może zniknąć nawet $75 \mathrm{mln}$ miejsc pracy na całym świecie. Roboty i inteligentne systemy komputerowe mogą mieć większy wpływ na nasze życie, niż było w przypadku pojawienia się internetu. Informatyzacja będzie przyspieszała dzięki postępom w uczeniu się maszynowym (machine learning) oraz dzięki wzrostowi liczby danych, jakie gromadzimy wokół nas. Powstają już roboty, które potrafią wykonywać proste prace ręczne, np. pakowanie i przenoszenie towaru. Magazyny przyszłości będą pozbawione oświetlenia, ponieważ będą obsługiwane wyłącznie przez roboty.

W raporcie Światowego Forum Ekonomicznego czytamy, że do 2020 r. zniknie 5 mln miejsc pracy z powodu wprowadzenia do procesów produkcyjnych sztucznej inteligencji, robotów, nanotechnologii itp. Z drugiej strony dokładnie $z$ tego samego powodu powstanie 2,1 mln nowych miejsc pracy (World Economic Forum 2016). Większość nowych miejsc pracy będzie wymagała zaawansowanych umiejętności. Klaus Schwab, założyciel i przewodniczący Światowego Forum Ekonomicznego (World Economic Forum 2016), jest przekonany, że rządy powinny podejmować działania zmierzające do przygotowywania pracowników do zmieniających się realiów. Profesor David Deming z Uniwersytetu Harvarda uważa, że najważniejsze będą umiejętności miękkie, takie jak współuczestniczenie w sieciach społecznych i negocjowanie. Jego zdaniem w nowoczesnych miejscach pracy pracownicy 
będą musieli odgrywać różne role - będzie to nieco przypominało funkcjonowanie dzieci w przedszkolu (wiele różnych ról, niska stabilność struktur społecznych, duże znaczenie empatii i współpracy). Deming zaproponował typologię różnych zawodów ze względu na dwie zmienne. Na osi X oznaczył umiejętności matematyczne, a na osi Y umiejętności społeczne. Na schemacie 1 przedstawiono przykłady zawodów ze względu na intensywność wykorzystywania umiejętności matematycznych i społecznych. Zawody w lewej dolnej ćwiartce nie wymagają ani zaawansowanych umiejętności społecznych, ani matematycznych. $Z$ kolei zawody oznaczone w górnej prawej ćwiartce wymagają zarówno umiejętności społecznych, jak i matematycznych.

Schemat 1. Popyt na kompetencje matematyczne i społeczne wg zawodów

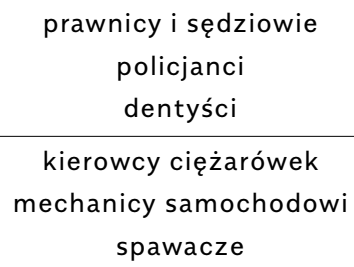

dyrektorzy finansowi ekonomiści lekarze matematycy kasjerzy bankowi księgowi operatorzy maszyn

Źródło: The Future of Jobs... 2016.

\section{Rozwój kreatywności a system egzaminów}

Miernikiem zakończonego sukcesem procesu edukacji jest trwała zdolność posiadacza zdobytej wiedzy, rozwiniętych postaw i umiejętności do zastosowania ich w specyficznej sytuacji lub kontekście odnoszącym się bezpośrednio do definicji zawodu. Zakończony powodzeniem egzamin, który miałby stymulować (już przez samo swoje istnienie) rozwój kreatywności w szkole, powinien opierać się na innych założeniach niż egzamin sprawdzający wiedzę ucznia. Niektóre kompetencje mają charakter związany z wykazaniem się kreatywnością dziedzinową (domain-specific), a inne są uniwersalne, włączając $w$ to banalny już test na znalezienie jak największej liczby zastosowań spinacza (który nota bene został wynaleziony przez Polaka Józefa Hoffmana).

Odnosząc kwestię kreatywności ucznia do pojęcia umiejętności (a więc i potrzeb rynku pracy), można kreatywność zakwalifikować jako 
kompetencję przekrojową (transversal competence lub key competence) (Zimmermann 2018). Warto zauważyć, że kompetencje stanowią szerszy zakres pojęciowy niż wiedza i umiejętności (Rychen, Salganik 2000). Kompetencje mogą być definiowane jako „ogół wiedzy, umiejętności i postaw" (sum of knowledge, skills and attitudes - definicja stosowana przez Komisję Europejską). Z kolei OECD posługuje się bardziej rozbudowaną definicją uwzględniającą różne rodzaje kompetencji, z których na szczególne wyróżnienie w kontekście polskiego system edukacji zasługują:

$\rightarrow$ interaktywne wykorzystanie wiedzy i informacji,

$\rightarrow$ współpraca w heterogenicznych zespołach, w tym zarządzanie konfliktami i ich rozwiązywanie,

$\rightarrow$ autonomiczne działanie - rozumienie szerszego kontekstu, tworzenie planów na przyszłość i projektów związanych z życiem osobistym.

Umiejętności wiążą się z pewnym potencjałem do wykonywania zadań, a nie tym, co dana osoba wie. Kompetencje mogą charakteryzować zarówno jednostkę, jak i zespół, a także organizację. Kompetencje są pojęciem szerszym od umiejętności, ponieważ te drugie nie uwzględniają aspektów emocjonalnych ( $w$ tym związanych z motywacją do wykonywania zadań), a także systemu wartości, stosowanych strategii rozwiązywania problemów itp. W ramach kompetencji mieszczą się także nawyki i inne cechy psychologiczne jednostki (Guilland 2017). W dokumentach Komisji Europejskiej (The European Framework 2006) mowa jest o umiejętnościach poznawczych, takich jak komunikowanie się w języku ojczystym, komunikowanie się w językach obcych, kompetencje matematyczne, techniczne i z zakresu nauk ścisłych.

\section{Ocena a pomiar kreatywności ucznia}

Ocena (assessment) w edukacji jest definiowana jako proces zdobywania dowodów, dokonywania osądów i wyciągania wniosków dotyczących osiągnięć ucznia i jego dokonań (Curtis 2010). Ocena wiąże się więc z fazą analizy i zbierania danych oraz fazą wnioskowania i wartościowania. Najrzetelniejszą metodą pomiaru kompetencji są testy psychometryczne. Wykorzystywane są one powszechnie w procesie rekrutacji, ale także przy budowaniu zespołów, wspieraniu rozwoju zawodowego 
oraz w procesie zarządzania zmianą. Popularność testów, w tym realizowanych za pomocą internetu, stale rośnie ze względu na ich niski koszt i przeprowadzanie, obiektywność i porównywalność wyników oraz możliwość szybkiego przeprowadzenia na dużej populacji pracowników lub kandydatów. Testy te służą zbadaniu nie wszystkich kompetencji, jakimi dysponuje kandydat/pracownik, lecz przede wszystkim tych, które są potrzebne pracodawcy.

Ocena kompetencji jest szczególnie trudna, ponieważ trudno je precyzyjnie zdefiniować. Wiąże się z następującymi wyzwaniami (Gibb 2014):

$\rightarrow$ ustalenie kontekstu, czyli wkładu ze strony podmiotu dokonującego oceny - chodzi o właściwe zdefiniowanie wzorca doskonałości, który byłby punktem odniesienia do pomiaru;

$\rightarrow$ ustalenie treść zadań egzaminacyjnych;

$\rightarrow$ ustalenie metody weryfikacji, w szczególności poziomu zaangażowania osoby egzaminowanej-można wykorzystywać testy wiedzy, ale także symulacje i obserwację uczestniczącą; odpowiedzi deklarowane nie zawsze będą tożsame z rzeczywistymi zachowaniami danej osoby;

$\rightarrow$ wykorzystanie wyników oceny - wyniki oceny powinny pomagać osobom ocenianym w dalszym podnoszeniu swoich umiejętności; osoby oceniane powinny być samoświadome swoich zachowań, a wyniki powinny ułatwiać im znajdowanie motywacji wewnętrznej (być pozytywnymi bodźcami).

Reasumując, ocena kompetencji transferowalnych powinna (Ketchagias 2011):

$\rightarrow$ służyć celom diagnostycznym, ocenie formatywnej i sumatywnej, certyfikacji;

$\rightarrow$ wykorzystywać modele rozwoju kompetencji oparte na odkryciach z dziedziny kognitywistyki i dostosowywać do tych odkryć testy psychometryczne;

$\rightarrow$ wykorzystywać nowe media;

$\rightarrow$ wprowadzać ocenę umiejętności pracy w grupie i współpracy;

$\rightarrow$ uwzględniać kompetencje obywatelskie (local and global citizenship);

$\rightarrow$ umożliwiać sprawdzanie umiejętności uczniów dostosowane do indywidualnych cech ucznia. 
Ocena nie powinna odgrywać wyłącznie roli certyfikującej i podsumowującej proces nauczania. Powinna także być źródłem edukacji i motywatorem do dalszej nauki i doskonalenia się (Wiggins 1998). W związku z tym wszelkie nowoczesne formy egzaminowania stosowane w oświacie powinny uwzględniać postulat edukacyjno-rozwojowy. Zadania egzaminacyjne powinny być tak zaprojektowane i sformułowane, aby dawać uczniom wskazówki co do dalszego rozwoju. Właściwie zaprojektowane zadania egzaminacyjne powinny dostarczać informacji zwrotnej na temat aktualnego poziomu umiejętności ucznia oraz informować, jak powinien się rozwijać. Bardzo ważne jest także kształcenie takich umiejętności, które będą mogły być wykorzystywane przez ucznia w zróżnicowanych kontekstach (transferability of knowledge and competences) (Packer, Goicoechea 2000).

Tabela. 1. Kompetencje i sposoby ich oceny

\begin{tabular}{|c|c|c|c|}
\hline LP. & $\begin{array}{l}\text { NAZWA } \\
\text { IOPIS } \\
\text { KOMPE- } \\
\text { TENCJI }\end{array}$ & $\begin{array}{l}\text { POŻĄDANE ZACHOWANIE } \\
\text { PRACOWNIKA W MIEJSCU PRACY } \\
\text { WYNIKAJĄCE Z POSIADANIA DANEJ } \\
\text { KOMPETENCJI }\end{array}$ & $\begin{array}{l}\text { MOŻLIWE SPOSOBY WERYFIKACJI/OCENY W FORMIE } \\
\text { ZADANIA EGZAMINACYJNEGO }\end{array}$ \\
\hline 1. & $\begin{array}{l}\text { Dostrze- } \\
\text { ganie } \\
\text { emocji }\end{array}$ & $\begin{array}{l}\text { Pracownik dostrzega emocje } \\
\text { członków zespołu, przełożo- } \\
\text { nego, klientów i innych osób } \\
\text { i potrafi je nazwać. }\end{array}$ & $\begin{array}{l}\text { 1. Krótki film (Digital roleplay) pokazujący } \\
\text { sytuację w miejscu pracy, np. kłótnię między } \\
\text { pracownikiem a klientem, której świadka- } \\
\text { mi są inni klienci i przełożony. Uczeń ma } \\
\text { za zadanie opisać emocje uczestników } \\
\text { scenki. Poszczególni bohaterowie mogą się } \\
\text { różnie zachowywać (film powinien zostać } \\
\text { nakręcony przez zawodowych aktorów; dla } \\
\text { utrudnienia film powinien powstać w kilku } \\
\text { wariantach, tak aby w każdym wariancie } \\
\text { daną postać charakteryzowały inne emocje, } \\
\text { np. klient może być w jednym wariancie } \\
\text { przestraszony, a w drugim zdziwiony, z kolei } \\
\text { przełożony pracownika w jednym wariancie } \\
\text { może stać po stronie klienta, a w drugim być } \\
\text { zły na klienta itd.). Zadaniem osoby egzami- } \\
\text { nowanej jest nazwanie emocji poszczegól- } \\
\text { nych uczestników scenki. }\end{array}$ \\
\hline
\end{tabular}




\begin{tabular}{|c|c|c|c|}
\hline 2. & $\begin{array}{l}\text { Używanie } \\
\text { emocji }\end{array}$ & $\begin{array}{l}\text { Pracownik potrafi adekwat- } \\
\text { nie zareagować na zdarzenie } \\
\text { w swoim otoczeniu, używając } \\
\text { w odpowiedni sposób swoich } \\
\text { emocji. }\end{array}$ & $\begin{array}{l}\text { Testowanie tego typu kompetencji jest } \\
\text { utrudnione, ponieważ należałoby naj- } \\
\text { pierw wywołać pewne naturalne emocje, } \\
\text { np. przestraszyć, stworzyć zagrożenie, } \\
\text { obrazić osobę egzaminowaną. Z przyczyn } \\
\text { etycznych testowanie takich zachowań } \\
\text { jest niemożliwe lub bardzo utrudnione } \\
\text { (wszelkie formy „łagodniejszej” ekspozycji } \\
\text { na emocje w trakcie symulacji mogą nie dać } \\
\text { rzetelnych wyników). } \\
\text { Można natomiast przedstawić opisy sytu- } \\
\text { acji (w formie pisemnej lub, jak opisano to } \\
\text { wyżej - w formie filmu) i prosić osobę eg- } \\
\text { zaminowaną o ocenę zasadności zachowań } \\
\text { ocenianej postaci. W ten sposób można, } \\
\text { przynajmniej na poziome deklaratywnym, } \\
\text { ocenić, czy osoba egzaminowana zna wła- } \\
\text { ściwe sposoby używania emocji w różnych } \\
\text { sytuacjach. } \\
\text { W filmie osoba egzaminowana ma dokony- } \\
\text { wać oceny sytuacji (Situational Judgement } \\
\text { Test). Film co kilkanaście sekund jest prze- } \\
\text { rywany, a osoba uczestnicząca w egzaminie } \\
\text { (uczeń) ma za zadanie odpowiedzieć na } \\
\text { pytanie o wielu wariantach odpowiedzi. }\end{array}$ \\
\hline 3. & $\begin{array}{l}\text { Rozumie- } \\
\text { nie emocji }\end{array}$ & $\begin{array}{l}\text { Pracownik jest świadomy swo- } \\
\text { ich emocji, potrafi je nazwać } \\
\text { i zna ich konsekwencje dla swo- } \\
\text { jego funkcjonowania i relacji } \\
\text { z innymi. }\end{array}$ & $\begin{array}{l}\text { Rozumienie emocji nie jest tożsame ze } \\
\text { zdolnością do ich werbalnego określenia. } \\
\text { Ważniejsza jest „szczerość z samym sobą" } \\
\text { tzn. m.in. zdolność do przyznania się do } \\
\text { błędu, przyznanie przed samym sobą, że } \\
\text { kogoś się uraziło lub zraniło (poczucie } \\
\text { winy). }\end{array}$ \\
\hline 4. & $\begin{array}{l}\text { Zarzą- } \\
\text { dzanie } \\
\text { emocjami }\end{array}$ & $\begin{array}{l}\text { Umiejętność opanowywania } \\
\text { stresu, powstrzymanie się od } \\
\text { agresywnych zachowań. }\end{array}$ & $\begin{array}{l}\text { Ta umiejętność może być sprawdzana } \\
\text { najskuteczniej w rzeczywistych sytuacjach } \\
\text { wymagających zarządzania emocjami: trud- } \\
\text { no stosować takie podejście sprawdzające } \\
\text { umiejętności osoby egzaminowanej w cza- } \\
\text { sie egzaminu szkolnego. Można natomiast } \\
\text { posłużyć się metodami egzaminowania } \\
\text { sprawdzającymi poziom świadomości zna- } \\
\text { czenia zarządzania emocjami. }\end{array}$ \\
\hline
\end{tabular}




\begin{tabular}{|c|c|c|c|}
\hline 5. & $\begin{array}{l}\text { Zarzą- } \\
\text { dzanie } \\
\text { relacjami } \\
\text { z innymi }\end{array}$ & $\begin{array}{l}\text { (Współ)tworzenie atmosfery } \\
\text { sprzyjającej produktywnej } \\
\text { pracy w zespole pracowni- } \\
\text { ków, podtrzymywanie relacji } \\
\text { zawodowych i osobistych ze } \\
\text { współpracownikami i klienta- } \\
\text { mi (tam, gdzie to wskazane), } \\
\text { dobieranie adekwatnych form } \\
\text { i treści w komunikacji interper- } \\
\text { sonalnej. }\end{array}$ & $\begin{array}{l}\text { Ta umiejętność może być sprawdzana } \\
\text { najskuteczniej w rzeczywistych sytuacjach } \\
\text { wymagających zarządzania relacjami z inny- } \\
\text { mi ludźmi: trudno stosować takie podejście } \\
\text { sprawdzające umiejętności osoby egzamino- } \\
\text { wanej w czasie egzaminu szkolnego. Można } \\
\text { natomiast posłużyć się metodami egzami- } \\
\text { nowania sprawdzającymi poziom świadomo- } \\
\text { ści znaczenia zarządzania relacjami. Można } \\
\text { ucznia pytać o to, jakimi kryteriami kieruje } \\
\text { się w nawiązywaniu znajomości, jakie ma } \\
\text { podejście do kultywowania znajomości. } \\
\text { W pewnych zawodach (przede wszystkim } \\
\text { usługowych) zarządzanie relacjami z innymi } \\
\text { może być kluczową kompetencją, np. } \\
\text { w hotelarstwie, handlu, sprzedaży, usługach } \\
\text { prawniczych itd. }\end{array}$ \\
\hline 6. & $\begin{array}{l}\text { Myślenie } \\
\text { strategicz- } \\
\text { ne }\end{array}$ & $\begin{array}{l}\text { Dotyczy zdolności do podej- } \\
\text { mowania decyzji, dokonywania } \\
\text { wyborów między różnymi } \\
\text { opcjami, rozumienia krótko- } \\
\text { i długookresowych konsekwen- } \\
\text { cji swoich działań. }\end{array}$ & $\begin{array}{l}\text { Sprawdzenie tej kompetencji wymaga stwo- } \\
\text { rzenia sytuacji, w której osoba egzaminowa- } \\
\text { na na podstawie będących w jej dyspozycji } \\
\text { informacji ma podjąć jakąś decyzję życiową } \\
\text { lub zawodową. Decyzja ta może dotyczyć } \\
\text { zaciągnięcia kredytu hipotecznego, zmiany } \\
\text { miejsca pracy, przeprowadzki do innego } \\
\text { miasta, zakupu dobra trwałego użytku itp. } \\
\text { Osoba egzaminowana w zadanym czasie } \\
\text { na podstawie będących w jej dyspozycji } \\
\text { informacji ma podjąć decyzję, a następie } \\
\text { ją uzasadnić. Ocena kompetencji może } \\
\text { odbyć się zarówno na podstawie odpowiedzi } \\
\text { na pytania wielokrotnego wyboru, jak i na } \\
\text { podstawie rozmowy oceniającej (ocena jako- } \\
\text { ściowa). Przy ocenie myślenia strategicznego } \\
\text { oprócz samej decyzji należy zweryfikować } \\
\text { schematy myślowe i sam proces myślenia } \\
\text { prowadzący do danej decyzji. } \\
\text { Zadanie może być utrudniane przez wpro- } \\
\text { wadzenie w czasie jego rozwiązywania } \\
\text { dystraktorów (czynników rozpraszających } \\
\text { uwagę, przeszkadzających w skupieniu). } \\
\text { W ten sposób można także oceniać zdolność } \\
\text { do radzenia sobie ze stresem i jego wpływ na } \\
\text { jakość podejmowanych decyzji. }\end{array}$ \\
\hline 7. & $\begin{array}{l}\text { Zarządza- } \\
\text { nie sobą } \\
\text { w czasie }\end{array}$ & $\begin{array}{l}\text { Dotyczy planowania swojej } \\
\text { pracy i odpoczynku, wyboru } \\
\text { priorytetów, delegowania zadań. }\end{array}$ & $\begin{array}{l}\text { Zadanie może polegać na wykorzystaniu } \\
\text { jednego z wielu narzędzi zarządzania sobą } \\
\text { w czasie. Osoba egzaminowana mogłaby } \\
\text { za pomocą jednego z takich narzędzi opra- } \\
\text { cować plan lub analizę swojego tygodnia } \\
\text { i zasugerować w drugiej części jego optyma- } \\
\text { lizację (plan poprawy). }\end{array}$ \\
\hline
\end{tabular}




\begin{tabular}{|c|c|c|c|}
\hline 8. & $\begin{array}{l}\text { Zdolność } \\
\text { do odnaj- } \\
\text { dywania } \\
\text { sensu } \\
\text { (sense- } \\
\text {-making }\end{array}$ & $\begin{array}{l}\text { W miarę jak robotyzacja i auto- } \\
\text { matyzacja coraz większej liczby } \\
\text { działań będą postępować, } \\
\text { umiejętności techniczne zwią- } \\
\text { zane z obsługą maszyn, w tym } \\
\text { także programowaniem, będą } \\
\text { stawać się zbędne. Komputery } \\
\text { dzięki swojej mocy obliczenio- } \\
\text { wej będą w stanie zastępować } \\
\text { człowieka w takich zadaniach } \\
\text { jak analiza danych. Najsłabszą } \\
\text { stroną komputerów jest ich } \\
\text { niezdolność do wykazywania } \\
\text { się inteligencją. W związku } \\
\text { z tym obszarami, w których } \\
\text { ludzie będą nadal dominować } \\
\text { nad maszynami, będzie zdol- } \\
\text { ność do krytycznego myślenia } \\
\text { i tworzenia sensu. Można więc } \\
\text { powiedzieć, że jeśli ktoś myśli } \\
\text { o swojej karierze w perspekty- } \\
\text { wie 15-20 lat, powinien raczej } \\
\text { inwestować swój czas w sa- } \\
\text { morozwój w obszarze filozofii, } \\
\text { etyki, socjologii, historii. }\end{array}$ & $\begin{array}{l}\text { Wszelkie zadania, w których problem jest } \\
\text { nieprecyzyjnie zdefiniowany (ill-defined). } \\
\text { Zadania z nieprecyzyjnie zdefiniowanym } \\
\text { problemem trudniej oceniać, ponieważ ist- } \\
\text { nieje wiele możliwych rozwiązań problemu. } \\
\text { Przy ich ocenie należy brać pod uwagę sam } \\
\text { proces dochodzenia do rozwiązania, a nie } \\
\text { tylko uzyskany wynik. Proces rozumowania } \\
\text { oparty na jak największej liczbie zmiennych } \\
\text { i hipotez sformułowanych przez osobę } \\
\text { egzaminowaną powinien być odpowiednio } \\
\text { wyżej oceniony niż proces oparty na małej } \\
\text { liczbie hipotez i zmiennych wziętych pod } \\
\text { uwagę. }\end{array}$ \\
\hline 9. & $\begin{array}{l}\text { Zdol- } \\
\text { ność do } \\
\text { adaptacji } \\
\text { i elastycz- } \\
\text { ność }\end{array}$ & $\begin{array}{l}\text { Ta kompetencja pojawia się już } \\
\text { w propozycjach zadań egza- } \\
\text { minacyjnych na } 2019 \text { r., lecz } \\
\text { występuje pod nieprecyzyjna } \\
\text { nazwą „zarządzanie zmianą". } \\
\text { Wiąże się z efektywnością } \\
\text { w rozwiązywaniu proble- } \\
\text { mów wymagających myśle- } \\
\text { nia krytycznego. Na rynku } \\
\text { pracy następuje polaryzacja } \\
\text { zapotrzebowania na kompe- } \\
\text { tencje pracowników. Zanikają } \\
\text { zawody wymagające średnich } \\
\text { umiejętności, ponieważ zostają } \\
\text { one wyparte przez automaty- } \\
\text { zację (np. bankowość) lub przez } \\
\text { offshoring. Jednocześnie rośnie } \\
\text { liczba miejsc pracy wymagają- } \\
\text { cych bardzo niskich kwalifikacji } \\
\text { oraz zawodów wymagających } \\
\text { bardzo wysokich kwalifikacji. } \\
\text { W tej drugiej grupie zawodów } \\
\text { szczególnie liczy się zdol- } \\
\text { ność do adaptacji do nowych } \\
\text { warunków. }\end{array}$ & $\begin{array}{l}\text { Zdolność do adaptacji i elastyczność są bar- } \\
\text { dzo często wymieniane jako pożądane cechy } \\
\text { pozytywne uczniów i absolwentów systemu } \\
\text { edukacji. Są one jednak silnie powiązane } \\
\text { z osobowością, na której konstrukcję ma } \\
\text { wpływ nie tylko wychowanie, ale też geny. } \\
\text { Podstawą zwiększania adaptacyjności jest } \\
\text { trening opuszczania strefy komfortu. Im } \\
\text { większa jest strefa komfortu danej osoby, } \\
\text { tym trudniej jest jej poddać się procesowi } \\
\text { zmiany. Zdolność do adaptacji i elastyczność } \\
\text { są związane z tolerancją ryzyka. Tolerancja } \\
\text { ryzyka jest według wielu badań cechą danej } \\
\text { kultury. Według powszechnie uznawa- } \\
\text { nych na świecie badań autorstwa Geerta } \\
\text { Hofstede polską kulturę narodową cechuje } \\
\text { bardzo wysoki wskaźnik unikania ryzyka } \\
\text { (uncertainty avoidance), który wynosi } 93 \text {. } \\
\text { Dla porównania dla Niemiec wynosi on } 65, \\
\text { dla Wielkiej Brytanii } 35, \text { dla Czech } 74, \text { dla } \\
\text { Stanów Zjednoczonych } 46 \text {. Konkludując, } \\
\text { ocena adaptacyjności ucznia jest możliwa, } \\
\text { natomiast trudno jednoznacznie przypisy- } \\
\text { wać ją wpływowi systemu edukacji. Wpływ } \\
\text { czynników kulturowych i genetycznych jest } \\
\text { tutaj znaczący. }\end{array}$ \\
\hline
\end{tabular}




\begin{tabular}{|c|c|c|c|}
\hline 10. & $\begin{array}{l}\text { Kompe- } \\
\text { tencje } \\
\text { między- } \\
\text { kulturowe }\end{array}$ & $\begin{array}{l}\text { Rosnąca globalizacja powoduje, } \\
\text { że zarówno wśród pracowników, } \\
\text { jak i klientów coraz większej } \\
\text { liczby firm pojawiają się osoby } \\
\text { z innych krajów i kultur. Kiedyś } \\
\text { wiedza o innych kulturach } \\
\text { pochodziła z książek podróż- } \\
\text { niczych, filmów fabularnych } \\
\text { i dokumentalnych. Dzisiaj coraz } \\
\text { więcej sytuacji w naszym życiu } \\
\text { wiąże się z koniecznością inte- } \\
\text { rakcji z osobami z innych kultur. } \\
\text { Często oznacza to akceptację } \\
\text { dla odmiennych zachowań, } \\
\text { a także konieczność uczenia się } \\
\text { i adaptacji do nich. }\end{array}$ & $\begin{array}{l}\text { Kompetencje międzykulturowe nie powinny } \\
\text { być utożsamiane z akceptacją dla różno- } \\
\text { rodności (choć są z nią silnie powiązane). } \\
\text { Chodzi tutaj o zdolność do skutecznego } \\
\text { zarządzania zespołami wielokulturowymi } \\
\text { i pracy w nich zespołach. } \\
\text { Początek procesu weryfikacji tej kompetencji } \\
\text { powinien obejmować sprawdzenie wiedzy na } \\
\text { temat specyfiki różnych kultur (istnieje bogata } \\
\text { literatura na temat cech specyficznych różnych } \\
\text { kultur, także w kontekście kultury współpracy). } \\
\text { Na wyższym poziomie zweryfikowane powinny } \\
\text { zostać zdolności do pracy w zespołach wielo- } \\
\text { kulturowych. Można posłużyć się filmami in- } \\
\text { struktażowymi. Osoba egzaminowana powinna } \\
\text { zdefiniować specyficzne zachowania członków } \\
\text { zespołu i opisać ich przyczyny. }\end{array}$ \\
\hline 11. & $\begin{array}{l}\text { Kompe- } \\
\text { tencje } \\
\text { medialne }\end{array}$ & $\begin{array}{l}\text { Umiejętność korzystania z no- } \\
\text { wych mediów stanie się niedłu- } \\
\text { go bardzo ważna, ponieważ tra- } \\
\text { dycyjne media, takie jak radio } \\
\text { czy telewizja, będą traciły swój } \\
\text { monopol. Jeszcze } 10 \text { lat temu } \\
\text { w podręcznikach marketingu } \\
\text { internet był traktowany jako } \\
\text { medium pomocnicze na równi } \\
\text { z banerami, gadżetami itp. }\end{array}$ & $\begin{array}{l}\text { Osoba egzaminowana powinna odróżniać: } \\
\rightarrow \text { opinie od faktów; } \\
\rightarrow \text { plotki od informacji publiczne; } \\
\rightarrow \text { prezentację obiektywną od subiektywnej; } \\
\rightarrow \text { prezentację realistyczną od surrealistycz- } \\
\text { nej, dramatycznej, nadmiernie dramatycznej } \\
\text { i melodramatycznej; } \\
\rightarrow \text { reklamę od przekazu niekomercyjnego; } \\
\rightarrow \text { gatunki dziennikarskie (reportaż, film fabu- } \\
\text { larny, film komediowy, dramat, wiadomości); } \\
\rightarrow \text { problemy życia rzeczywistego od proble- } \\
\text { mów prezentowanych w mediach. } \\
\text { Ponadto uczeń powinien znać sposoby } \\
\text { manipulacji widzem, narzucania przez media } \\
\text { stereotypów. }\end{array}$ \\
\hline 12. & $\begin{array}{l}\text { Między- } \\
\text { dyscypli- } \\
\text { narność }\end{array}$ & $\begin{array}{l}\text { Wiele z dzisiejszych problemów, } \\
\text { jakie nas otaczają, nie może } \\
\text { być rozwiązana dzięki wiedzy } \\
\text { z jednej dyscypliny naukowej. Dla } \\
\text { pracowników firm zajmujących } \\
\text { się analizą trendów rynkowych } \\
\text { i pracowników centrów badaw- } \\
\text { czo-rozwojowych oznacza to, że } \\
\text { będą musieli poruszać się w po- } \\
\text { przek dyscyplin. Biolodzy będą } \\
\text { musieli zrozumieć matematykę, } \\
\text { a matematycy biologię. Idealny } \\
\text { pracownik przyszłości to ktoś, } \\
\text { kto jest wyposażony w umiejęt- } \\
\text { ności w kształcie litery „T"1. }\end{array}$ & $\begin{array}{l}\text { Uczeń powinien wykazać się zdolnością do } \\
\text { myślenia dywergencyjnego, czyli zmiany } \\
\text { kierunku myślenia i perspektywy. Można } \\
\text { to zweryfikować na podstawie udzielanych } \\
\text { odpowiedzi w kontekście problemów wyma- } \\
\text { gających skomplikowanych rozwiązań. }\end{array}$ \\
\hline
\end{tabular}

$1 \quad$ Koncepcja kompetencji w kształcie litery T (T-shaped skills) lub osób posiadających takie kompetencje ( $T$-shaped persons) jest metaforą ilustrującą przecinanie się lub współwystępowanie kompetencji niepowiązanych ze sobą dziedzinowo, np. umiejętność pisania wierszy + umiejętność programowania robota. Umiejętności te są bardzo cenione na rynku pracy, ponieważ ułatwiają budowanie multidyscyplinarnych zespołów. 


\begin{tabular}{|c|c|c|c|}
\hline 13. & $\begin{array}{l}\text { Zdolność } \\
\text { do radze- } \\
\text { nia sobie } \\
\text { z przeła- } \\
\text { dowaniem } \\
\text { kognityw- } \\
\text { nym }\end{array}$ & $\begin{array}{l}\text { Dotyczy umiejętności filtrowania } \\
\text { i ignorowania pewnych infor- } \\
\text { macji. W sytuacji, gdy zalewa } \\
\text { nas rosnący strumień informa- } \\
\text { cji, zdolność do umiejętnego } \\
\text { selekcjonowania ma kluczowe } \\
\text { znaczenie dla produktywności } \\
\text { pracownika. }\end{array}$ & $\begin{array}{l}\text { Kompetencja ta jest związana w dużym } \\
\text { stopniu z ogólną zdolnością do koncentra- } \\
\text { cji oraz zarządzania sobą. Można ją badać } \\
\text { na podstawie zdolności do dokonywania } \\
\text { selekcji informacji. Uczeń mógłby w czasie } \\
\text { zadania egzaminacyjnego dokonać wyboru } \\
\text { wartościowych informacji spośród szerszego } \\
\text { zbioru informacji ważnych i nieważnych. }\end{array}$ \\
\hline 14. & $\begin{array}{l}\text { Zdolność } \\
\text { do projek- } \\
\text { towania } \\
\text { (design } \\
\text { mindset) }\end{array}$ & $\begin{array}{l}\text { Z wielu badań wynika, że } \\
\text { sposób, w jaki zaprojektujemy } \\
\text { nasze otoczenie, ma wpływ na } \\
\text { to, jak postrzegamy świat oraz } \\
\text { jak się zachowujemy (Eberhard, } \\
\text { Patoine 2004). }\end{array}$ & $\begin{array}{l}\text { Projektowanie jest typową kompetencją } \\
\text { przekrojową. Projektować można wszyst- } \\
\text { ko, bez względu na rodzaj wykonywanego } \\
\text { zawodu. Stąd też zadania egzaminacyjne } \\
\text { powinny być dostosowane do specyfiki } \\
\text { zawodu osoby egzaminowanej. }\end{array}$ \\
\hline 15. & $\begin{array}{l}\text { Ocena } \\
\text { i analiza } \\
\text { długoter- } \\
\text { minowych } \\
\text { konse- } \\
\text { kwencji } \\
\text { zjawisk } \\
\text { i działań }\end{array}$ & $\begin{array}{l}\text { Orientacja długookresowa jest } \\
\text { typową kompetencją prze- } \\
\text { krojową. Wiąże się z realizacją } \\
\text { celów długookresowych oraz } \\
\text { powstrzymaniem się od szybkiej } \\
\text { gratyfikacji. Przydaje się zarówno } \\
\text { przy zarządzaniu pracą własną, } \\
\text { jak i w pracy zespołowej. } \\
\text { Hamowanie jest jedną z naszych } \\
\text { najczęściej używanych funkcji } \\
\text { poznawczych. To sposób, w jaki } \\
\text { mózg koryguje zachowanie. Ha- } \\
\text { mowanie sprawia, że możliwe dla } \\
\text { nas staje się, aby siedzieć cicho, } \\
\text { gdy chcemy coś powiedzieć, ale } \\
\text { wiemy, że nie należy tego robić. } \\
\text { Pomaga też zachować spokój } \\
\text { i pozycję siedzącą, kiedy jeste-- } \\
\text { śmy w klasie, pomaga zachować } \\
\text { bezpieczeństwo i czujność, gdy } \\
\text { ktoś zmienia pas bez używania } \\
\text { kierunkowskazu, pomaga studio- } \\
\text { wać lub pracować nawet wtedy, } \\
\text { gdy znudzimy się lub chcemy } \\
\text { wstać (Czym jest hamowanie?). }\end{array}$ & $\begin{array}{l}\text { Nieskuteczne hamowanie może przejawiać } \\
\text { się na trzech różnych poziomach (Czym jest } \\
\text { hamowanie?): } \\
\rightarrow \text { motorycznym: jeśli brakuje umiejętności } \\
\text { kontroli zachowań motorycznych, objawia } \\
\text { się to nadpobudliwością; } \\
\rightarrow \text { uwagi: przejawia się roztargnieniem } \\
\text { i trudnościami w utrzymaniu uwagi, np., gdy } \\
\text { czytamy książkę i jesteśmy rozproszeni, po- } \\
\text { nieważ słyszymy dzwonek do drzwi sąsiada } \\
\text { lub widzimy cień gołębicy przechodzącej } \\
\text { po parapecie; } \\
\rightarrow \text { zachowań: przejawia się w nieprzemyśla- } \\
\text { nych postawach, przykładowo, naciska się } \\
\text { wściekle na klakson, gdy światło zmieniło } \\
\text { się na zielone, ale kierowca z przodu nie } \\
\text { ruszył automatycznie. } \\
\rightarrow \text { Kompetencję tę można badać w sytu- } \\
\text { acjach symulowanych, w których osoba } \\
\text { egzaminowana nie zna celu badania (jest on } \\
\text { ukryty). }\end{array}$ \\
\hline 16 & $\begin{array}{l}\text { Umiejęt- } \\
\text { ność pracy } \\
\text { zespoło- } \\
\text { wej }\end{array}$ & $\begin{array}{l}\text { Może objawiać się w wielu róż- } \\
\text { nych sytuacjach, wśród których } \\
\text { można wymienić np. pracę nad } \\
\text { kilkoma projektami jednocześnie } \\
\text { dla kilku zlecających, aktyw- } \\
\text { ność sportową, uczestnictwo } \\
\text { w stowarzyszeniach, harcerstwie, } \\
\text { zbiórkach publicznych na cele } \\
\text { charytatywne itd. Najważniejsze } \\
\text { jest wykazanie przed pracodaw- } \\
\text { cą swojej sprawności społecznej. }\end{array}$ & $\begin{array}{l}\text { Umiejętność tę można sprawdzać zarówno } \\
\text { dzięki analizie dotychczasowej aktywności } \\
\text { osoby egzaminowane, jak i w sytuacjach } \\
\text { symulowanych. Należy zwrócić uwagę, że } \\
\text { umiejętność pracy zespołowej wiąże się } \\
\text { w dużym stopniu z właściwym dobraniem } \\
\text { kompetencji członków zespołu do wykony- } \\
\text { wanego zadania. Nie można na podstawie } \\
\text { powierzchownej obserwacji i arbitralnej } \\
\text { oceny stwierdzić, że dana osoba jest lub nie } \\
\text { jest dobrym „graczem zespołowym”. }\end{array}$ \\
\hline
\end{tabular}

Źródło: opracowanie własne. 
Szkoła stanowi doskonałe miejsce na rozwijanie kreatywności u uczniów, ponieważ oferuje możliwości stymulacji umysłu, z którymi uczeń nie mógłby zetknąć się w innych sytuacjach (np. w domu, na wakacjach z rodzicami, w czasie edukacji domowej). Nawet w swojej obecnej, archaicznej formie ma olbrzymi potencjał. Nie można przy tym lekceważyć ustaleń psychologii kreatywności, która podkreśla znaczenie przeszkód (constraints) jako stymulatora rozwoju kreatywności. Innymi słowy, to, co z perspektywy krótkoterminowej uznajemy za przeszkodę („zabijanie kreatywności”), może mieć w dłuższej perspektywie pozytywny wpływ na sukcesy absolwentów szkoły. Postać innowatora, niedocenianego przez otoczenie, który mimo przeszkód odnosi sukces, jest dość powszechna w świadomości zbiorowej. W popkulturze określa się ją czasami mianem underdog, czyli kogoś, komu nie daje się szans na wygraną. Tę skuteczność w przezwyciężaniu przeszkód można i należy powiązać ze wcześniejszą edukacją szkolną w tym znaczeniu, że "szkoła zabijająca kreatywność" to jednocześnie szkoła ucząca walki z przeszkodami na drodze do rozwoju kreatywności, niezrozumieniem ze strony otoczenia, wrogością, życiem w poczuciu bycia niedocenianym itd.

Nie można mówić o rozwoju kreatywności u uczniów bez wskazania na kluczową rolę samych nauczycieli. Z badań wynika, że kreatywność nauczycieli jest tutaj niezbędna (Meintjes, Grosser 2010). Kreatywny nauczyciel na potrzeby danej sytuacji w klasie konstruuje doświadczenia w czasie lekcji, często improwizując i modyfikując swoje, znane mu wcześniej strategie i pomysły. Kluczowa jest więc nie tyle "kreatywność" zawarta w zaplanowanym z góry scenariuszu czy podstawie programowej. To spontaniczne dostosowywanie zachowania nauczyciela do danej sytuacji decyduje o wartości kreatywnej edukacji. I na odwrót, najbardziej „kreatywny” scenariusz lekcji realizowany przez pozbawionego entuzjazmu nauczyciela ściśle trzymającego się schematu nie będzie dobrym sposobem na rozwój kreatywności uczniów (Hojat 2004). Susan Brookhart $(2010,2013)$ zaproponowała Rubrics of Creativity, czyli sposób ewaluacji kreatywności. Zgodnie z nim kreatywność można oceniać w dwóch wymiarach i według czterech stopni oceny, odpowiednio: bardzo kreatywny, kreatywny, zwykły/ rutynowy i imitacyjny. $W$ drugim wymiarze kreatywności znajdują się następujące kryteria oceny: różnorodność idei i kontekstów, różnorodność wykorzystywanych przez ucznia źródeł, używanie pomysłów 
z różnych źródeł - kombinacja, wniesienie nowej wartości/przedstawienie nowej jakości. Jednak zdaniem autorki jej koncepcja nie ma służyć klasycznej ocenie, lecz przede wszystkim pomagać nauczycielom w przybliżeniu kryteriów oceny kreatywności ucznia. Innymi cechami kreatywnego ucznia, które mogłyby być brane pod uwage przy jego ocenie, są m.in.:

$\rightarrow$ zdolność do syntetyzowania pomysłów w oryginalny i zadziwiający sposób (kryterium zadziwienia odbiorców/publiczności jest uznawane za jeden z predyktorów kreatywności dzieła),

$\rightarrow$ zadawanie pytań, ogólna ciekawość poznawcza,

$\rightarrow$ szeroki zakres poszukiwań, otwarcie umysłu na inspiracje z różnych obszarów,

$\rightarrow$ zdolność do komunikowania/przedstawiania swojego pomysłu odbiorcom.

\section{Kreatywność ucznia jako wyzwanie dla systemu egzaminów i oceny pracy ucznia}

Niektórzy eksperci jako przyczynę niewystarczającego nacisku na kształtowanie kompetencji proinnowacyjnych w szkołach wskazują brak instrukcji i wskazówek dla nauczycieli we wszystkich krajach europejskich w kwestii sposobu nauczania kreatywności. W tabeli 2 przedstawiono przykłady zadań egzaminacyjnych (w odniesieniu do egzaminu zawodowego $w$ zawodzie górnik eksploatacji podziemnej), które zostały opatrzone komentarzem dotyczącym możliwości ich modyfikacji w taki sposób, aby w czasie ich rozwiązania zwrócono większą uwagę na ocenę kreatywności ucznia. Komentarze te ilustrują tezę, że zwiększenie znaczenia pomiaru kreatywności w szkole niekoniecznie musi wiązać się ze zmianami rewolucyjnymi dla funkcjonowania szkoły. Bardzo często drobne modyfikacje czy przeniesienie akcentu mogą diametralnie przesunąć punkt ciężkości pomiaru w danym zadaniu - w kierunku postulowanego zwiększenia nacisku na ewaluację kreatywności ucznia. 
Tabela 2. Ocena propozycji kształcenia

\begin{tabular}{|c|c|}
\hline $\begin{array}{l}\text { ELEMENT PODSTAWY } \\
\text { PROGRAMOWEJ } \\
\text { (EFEKTY KSZTAKCENIA ORAZ } \\
\text { KRYTERIA WERYFIKACJI) } \\
\end{array}$ & $\begin{array}{l}\text { UWAGI I SUGESTIE ZWIĄZANE Z MOŻLIWOŚCIĄ UDOSKONALENIA POD } \\
\text { KĄTEM KOMPETENCJI PRZEKROJOWYCH }\end{array}$ \\
\hline \multicolumn{2}{|c|}{$\begin{array}{l}\text { PODSTAWA PROGRAMOWA KSZTAŁCENIA W ZAWODZIE GÓRNIK EKSPLOATACJI PODZIEMNEJ. } \\
\text { SYMBOL CYFROWY ZAWODU 811101. Poziom III Polskiej Ramy Kwalifikacji określony dla zawodu } \\
\text { jako kwalifikacji pełnej. KWALIFIKACJA WYODRĘBNIONA W ZAWODZIE: GIW.11. Eksploatacja } \\
\text { złóż podziemnych. Poziom } 3 \text { Polskiej Ramy Kwalifikacji określony dla kwalifikacji. }\end{array}$} \\
\hline $\begin{array}{l}\text { 1. charakteryzuje pojęcia } \\
\text { związane z bezpieczeństwem } \\
\text { i higieną pracy, ochroną } \\
\text { przeciwpożarową, ochroną } \\
\text { środowiska i ergonomią. }\end{array}$ & $\begin{array}{l}\text { Należy położyć nacisk nie tylko na identyfikowanie, ale także } \\
\text { na społeczny kontekst zachowań, np. wpływ na otoczenie, śro- } \\
\text { dowisko naturalne, długookresowe negatywne skutki naruszenia } \\
\text { przepisów dla społeczeństwa oraz długookresowe pozytywne } \\
\text { skutki dbałości o ochronę środowiska. }\end{array}$ \\
\hline $\begin{array}{l}\text { 2. charakteryzuje prawa } \\
\text { i obowiązki pracownika oraz } \\
\text { pracodawcy w zakresie bez- } \\
\text { pieczeństwa i higieny pracy. }\end{array}$ & $\begin{array}{l}\text { Potrafi w opisanej sytuacji wskazać, jakie prawa zostały naruszo- } \\
\text { ne lub jakie będą konsekwencje danego zachowania pracownika. }\end{array}$ \\
\hline $\begin{array}{l}\text { 3. określa skutki oddziaływa- } \\
\text { nia czynników środowiska pra- } \\
\text { cy w górnictwie na organizm } \\
\text { człowieka. }\end{array}$ & $\begin{array}{l}\text { Ten obszar wiedzy można testować na podstawie przedstawie- } \\
\text { nia osobie egzaminowanej scenariuszy. Zadanie polegałoby na } \\
\text { wyborze właściwego/najbardziej odpowiedniego/korzystnego } \\
\text { scenariusza. }\end{array}$ \\
\hline $\begin{array}{l}\text { 5. wykonuje zadania zawo- } \\
\text { dowe zgodnie z zasadami } \\
\text { bezpieczeństwa i higieny } \\
\text { pracy, ochrony przeciwpo- } \\
\text { żarowej, ochrony środowiska } \\
\text { i ergonomii. }\end{array}$ & $\begin{array}{l}\text { Należy ściśle zdefiniować procesy wykonywane z zasadami } \\
\text { i z ich naruszeniem. Warto dokonać gradacji procesów/zadań } \\
\text { ze względu na ich niebezpieczeństwo (tzn. nie klasyfikować } \\
\text { wykonanych zadań wyłącznie zerojedynkowo (naruszył zasady } \\
\text { BHP/nie naruszył zasad BHP). }\end{array}$ \\
\hline $\begin{array}{l}\text { 2. rozróżnia rodzaje znaków } \\
\text { bezpieczeństwa i alarmów. }\end{array}$ & $\begin{array}{l}\text { Warto by poszerzyć o sprawdzenie wiedzy o konsekwencjach } \\
\text { nieprzestrzegania zaleceń zawartych w znakach itp. }\end{array}$ \\
\hline $\begin{array}{l}\text { 3. charakteryzuje prawa } \\
\text { i obowiązki pracownika oraz } \\
\text { pracodawcy w zakresie bez- } \\
\text { pieczeństwa i higieny pracy. }\end{array}$ & $\begin{array}{l}\text { Warto także zwrócić uwagę na relacje między pracownikami. } \\
\text { Wiele naruszeń prawa w miejscach pracy dotyczy relacji między- } \\
\text { pracowniczych (m.in. mobbing i bullying). } \\
\text { Potrafi w opisanej sytuacji wskazać, jakie prawa zostały naruszo- } \\
\text { ne lub jakie będą konsekwencje danego zachowania pracownika. } \\
\text { Tak jak w poprzednich przypadkach, zaleca się poszerzenie me- } \\
\text { tod egzaminowania o ocenę identyfikacji sytuacji na przykładzie } \\
\text { scenek sytuacyjnych (studiów przypadków). Osoba egzamino- } \\
\text { wana miałaby za zadanie odpowiedzieć na kilka pytań doty- } \\
\text { czących opisanej (lub obserwowanej - można posłużyć się np. } \\
\text { komiksem) sytuacji. Taki sposób egzaminowania byłby podobny } \\
\text { do pytań egzaminacyjnych na prawo jazdy. Kandydat na kierowcę } \\
\text { na podstawie zdjęcia z ruchu ulicznego ma wykazać się wiedzą }\end{array}$ \\
\hline $\begin{array}{l}\text { 5. charakteryzuje metody } \\
\text { wydobycia kopalin stałych. }\end{array}$ & $\begin{array}{l}\text { Warto sprawdzić na egzaminie szerszy kontekst, np. lokalizację } \\
\text { złóż, dalsze wykorzystanie kopalin w przemyśle („co się dzieje } \\
\text { dalej z węglem?"). }\end{array}$ \\
\hline
\end{tabular}


GIW.11.8. Język

obcy zawodowy

1. uczeń posługuje się pod-

stawowym zasobem środków językowych w języku obcym nowożytnym (ze szczególnym uwzględnieniem środków leksykalnych).
Należałoby stworzyć coś w rodzaju podstawy programowej języka zawodowego. Powinna ona zawierać listę np. 200 słów specjalistycznych.

Ponadto warto zastanowić się, czy rzeczywiście lepiej jest stawiać na język „zawodowy", czy też lepiej stworzyć zunifikowaną podstawę języka angielskiego dla szkół zawodowych, w ramach której istniałby komponent ściśle związany z danym zawodem (np. 200 słów, 200 zwrotów itp.).

Źródło: opracowanie własne.

\section{Propozycje zadań egzaminacyjnych możliwych do wykorzystania $w$ ramach egzaminu potwierdzającego kwalifikacje w zawodzie, sprawdzających kompetencje przekrojowe}

Na podstawie ustaleń definicyjnych i analizy w tabeli 3 zaprezentowano kilka zadań egzaminacyjnych możliwych do wykorzystania w ramach egzaminu potwierdzającego kwalifikacje w zawodzie w taki sposób, aby położyć większy nacisk na ocenę kreatywności ucznia.

Tabela 3. Opis zadań egzaminacyjnych uwzględniających kompetencje przekrojowe

\begin{tabular}{|c|c|c|}
\hline $\begin{array}{l}\text { NAZWA ZADANIA } \\
\text { EGZAMINOWANE } \\
\text { KOMPETENCJE } \\
\text { PRZEKROJOWE }\end{array}$ & OPIS ZADANIA & KRYTERIA OCENY \\
\hline $\begin{array}{l}\text { 1. Bezpieczeń- } \\
\text { stwo i higiena } \\
\text { pracy, ochrona } \\
\text { przeciwpoża- } \\
\text { rowa, ochrona } \\
\text { środowiska } \\
\text { i ergonomia } \\
\text { Wiedza o struk- } \\
\text { turze organiza- } \\
\text { cyjnej państwa } \\
\text { w kontekście } \\
\text { społeczno-eko- } \\
\text { nomicznym } \\
\text { wykonywanego } \\
\text { zawodu }\end{array}$ & $\begin{array}{l}\text { Zadanie powinno opisywać sytuację } \\
\text { kryzysową w kontekście konkretne- } \\
\text { go zawodu (np. górnika). Powinno } \\
\text { sprawdzać także wiedzę o procedu- } \\
\text { rach reagowania w sytuacjach za- } \\
\text { grożenia zdrowia i życia, np. w czasie } \\
\text { symulowanych scenek z miejsca wy- } \\
\text { padku lub poprzez obserwacje filmu } \\
\text { instruktażowego (osoba egzamino- } \\
\text { wana powinna po jego obejrzeniu } \\
\text { wskazać na błędy popełnione przez } \\
\text { bohaterów filmu w ich zachowaniu). }\end{array}$ & $\begin{array}{l}\text { Liczba zidentyfikowanych błędów } \\
\text { popełnionych przez bohatera lub bo- } \\
\text { haterów filmu. Za wskazanie działania } \\
\text { jako błędnego, które w istocie jest } \\
\text { prawidłowe, powinny być przyznawane } \\
\text { punktu ujemne. } \\
\text { Osoba egzaminowana ponadto ma } \\
\text { wskazać, jaką rolę w usuwaniu skutków } \\
\text { sytuacji kryzysowej mogą odgrywać } \\
\text { przedstawiciele jego zawodu, jak mogą } \\
\text { się przydać ich kompetencje. }\end{array}$ \\
\hline
\end{tabular}




\begin{tabular}{|c|c|c|}
\hline $\begin{array}{l}\text { 2. Zarządza- } \\
\text { nie kryzysowe } \\
\text { Zadania } \\
\text { i uprawnienia } \\
\text { instytucji oraz } \\
\text { służb działaja- } \\
\text { cych w zakresie } \\
\text { ochrony pracy } \\
\text { i ochrony środo- } \\
\text { wiska w Polsce }\end{array}$ & $\begin{array}{l}\text { Sprawdzenie wiedzy w tym zakresie } \\
\text { odbywa się w formie analizy studium } \\
\text { przypadku konkretnej sytuacji } \\
\text { kryzysowej. Osoba egzaminowana } \\
\text { ma wskazać, jakie instytucje powinny } \\
\text { być zaangażowane w usuwanie } \\
\text { skutków, jakie powinny być relacje } \\
\text { między nimi w procesie zarządzania } \\
\text { kryzysowego itp. }\end{array}$ & $\begin{array}{l}\text { Osoba egzaminowana analizuje } \\
\text { opis sytuacji kryzysowej (np. klęska } \\
\text { powodzi). Jej zadaniem jest wskazanie } \\
\text { instytucji, które powinny brać udział } \\
\text { w usuwaniu skutków analizowa- } \\
\text { nej sytuacji. } \\
\\
\text { Ponadto należy wskazać wynikające } \\
\text { z opisanej sytuacji skutki dla gospo- } \\
\text { darki i społeczeństwa. Dane zawarte } \\
\text { w opisie (np. powódź na terenach } \\
\text { turystycznych, w lipcu) powinny być } \\
\text { wskazówką dla odpowiedzi dotyczącej } \\
\text { ekonomicznych strat dla branży tury- } \\
\text { stycznej w regionie itp. }\end{array}$ \\
\hline $\begin{array}{l}\text { 3. Zagrożenia } \\
\text { związane z wy- } \\
\text { stępowaniem } \\
\text { czynników } \\
\text { w środowi- } \\
\text { sku pracy } \\
\text { Umiejętność } \\
\text { zachowania } \\
\text { bezpieczeń- } \\
\text { stwa własnego } \\
\text { oraz współ- } \\
\text { pracowników } \\
\text { i klientów }\end{array}$ & $\begin{array}{l}\text { Zadanie powinno angażować } \\
\text { osobę egzaminowaną. Powinna ona } \\
\text { w zainscenizowanej sytuacji podjąć } \\
\text { właściwe działania. } \\
\text { Osoba egzaminowana w czasie egza- } \\
\text { minu ogląda krótki (120-180 sekund) } \\
\text { film przedstawiający zachowanie } \\
\text { aktora w sytuacji związanej z wyko- } \\
\text { nywanym zawodem, z którego składa } \\
\text { egzamin. }\end{array}$ & $\begin{array}{l}\text { Zadaniem osoby egzaminowanej jest } \\
\text { odpowiednie zachowanie się w zain- } \\
\text { scenizowanej sytuacji, np. podczas } \\
\text { wypadku przy pracy. Egzaminator } \\
\text { powinien sprawdzić, czy podjęto wła- } \\
\text { ściwe działania, np. odłączono zasilanie } \\
\text { od urządzenia będącego na miejscu } \\
\text { zdarzenia, zawiadomiono w poprawny } \\
\text { sposób pogotowie, udzielono pierwszej } \\
\text { pomocy itp. zaniechanie działań } \\
\text { niezbędnych lub (np. nieodłączenie } \\
\text { prądu) powinno skutkować punktami } \\
\text { ujemnymi. }\end{array}$ \\
\hline $\begin{array}{l}\text { 4. Posługiwanie } \\
\text { się podstawo- } \\
\text { wym zaso- } \\
\text { bem środków } \\
\text { językowych } \\
\text { w języku obcym } \\
\text { nowożytnym } \\
\text { (ze szczegól- } \\
\text { nym uwzględ- } \\
\text { nieniem } \\
\text { środków } \\
\text { leksykalnych) } \\
\text { Realizacja } \\
\text { czynności } \\
\text { zawodowych } \\
\text { wjęzyku } \\
\text { angielskim }\end{array}$ & $\begin{array}{l}\text { Test językowy polegający na uzupeł- } \\
\text { nieniu pustych miejsc w zdaniach } \\
\text { o odpowiedni wyraz. Test ma } \\
\text { sprawdzać znajomość słownictwa } \\
\text { zawodowego. }\end{array}$ & $\begin{array}{l}\text { Osoba egzaminowana powinna uzu- } \\
\text { pełnić tekst o brakujące słowa. } \\
\\
\text { Innymi, komplementarnymi formami } \\
\text { egzaminowania mogą być m.in.: } \\
\rightarrow \text { napisanie tekstu krótkiego maila } \\
\text { opisującego problem zawodowy; } \\
\rightarrow \text { odpowiedź na mail w języku angiel- } \\
\text { skim dotyczący problemu klienta; } \\
\rightarrow \text { opisanie zdjęcia przedstawiającego } \\
\text { fragment warsztatu pracy (np. kuchnię } \\
\text { w restauracji, gabinet weterynaryjny, } \\
\text { gabinet masażysty) za pomocą nazw } \\
\text { poszczególnych przedmiotów w języku } \\
\text { angielskim. }\end{array}$ \\
\hline
\end{tabular}




\begin{tabular}{|c|c|c|}
\hline $\begin{array}{l}\text { 5. Rozumie- } \\
\text { nie prostych } \\
\text { wypowiedzi } \\
\text { ustnych w języ- } \\
\text { ku angielskim } \\
\text { Realizacja } \\
\text { czynności } \\
\text { zawodowych } \\
\text { w języku } \\
\text { angielskim }\end{array}$ & $\begin{array}{l}\text { Test językowy polegający na uzupeł- } \\
\text { nieniu pustych miejsc w zdaniach } \\
\text { o odpowiedni wyraz. Test ma spraw- } \\
\text { dzać znajomość słownictwa zawodo- } \\
\text { wego. Ponadto w treść opisywanych } \\
\text { sytuacji można włączyć zagadnienia } \\
\text { dotyczące kompetencji przekro- } \\
\text { jowych, takich jak praca w zespole, } \\
\text { adaptacja do zmiany, bezpieczeń- } \\
\text { stwo pracy. }\end{array}$ & $\begin{array}{l}\text { Osoba egzaminowana wysłuchuje } \\
\text { krótkiego (ok. 3-5 minut) nagrania } \\
\text { związanego z sytuacją zawodo- } \\
\text { wą. Może ono dotyczyć rozmowy } \\
\text { członków zespołu z liderem, rozmowy } \\
\text { z klientem w sprawach zawodowych } \\
\text { itp. Następnie osoba egzaminowana } \\
\text { ma za zadanie na podstawie testu wie- } \\
\text { lokrotnego wyboru wskazać odpowie- } \\
\text { dzi najtrafniej podsumowujące treść } \\
\text { wypowiedzi. }\end{array}$ \\
\hline $\begin{array}{l}\text { 6. Rozumie- } \\
\text { nie instrukcji } \\
\text { obsługi w języ- } \\
\text { ku angielskim } \\
\text { Realizacja } \\
\text { czynności } \\
\text { zawodowych } \\
\text { w języku } \\
\text { angielskim }\end{array}$ & $\begin{array}{l}\text { Zrozumienie instrukcji obsługi lub } \\
\text { regulaminów postępowania w języku } \\
\text { zawodowym to jedna z bardzo prak- } \\
\text { tycznych umiejętności. W zależności } \\
\text { od zawodu teksty techniczne mogą } \\
\text { dotyczyć zastosowania substancji } \\
\text { leczniczej lub urządzenia służącego } \\
\text { terapii (masażysta), obsługi maszyny, } \\
\text { dawkowania leku lub karmy (wetery- } \\
\text { narz) itp. }\end{array}$ & $\begin{array}{l}\text { Osoba egzaminowana ma za zadanie } \\
\text { przeczytać tekst instrukcji lub obsługi. } \\
\text { Następnie ma odpowiedzieć na serię } \\
\text { pytań po polsku sprawdzających, czy } \\
\text { poprawnie zrozumiała przeczytaną } \\
\text { instrukcję. }\end{array}$ \\
\hline $\begin{array}{l}\text { 7. Praca } \\
\text { zespołowa } \\
\text { i kompeten- } \\
\text { cje przywódcze } \\
\text { Umiejętność } \\
\text { pracy w zespole }\end{array}$ & $\begin{array}{l}\text { Osoba egzaminowana ma za zadanie } \\
\text { obserwować film, który przedsta- } \\
\text { wia spotkanie robocze zespołu } \\
\text { projektowego. W celu maksymalnego } \\
\text { przybliżenia kontekstu do sytuacji } \\
\text { zawodowej osoby egzaminowanej } \\
\text { film można nakręcić w różnych wer- } \\
\text { sjach - wersje będą różniły się: } \\
\text { a) tematyką rozwiązywane- } \\
\text { go problemu; } \\
\text { b) imionami bohaterów (aby utrudnić } \\
\text { uczniom uczenie się na pamięć). } \\
\text { Na obserwowanym filmie różne } \\
\text { postacie odgrywają różne role } \\
\text { w zespole. }\end{array}$ & 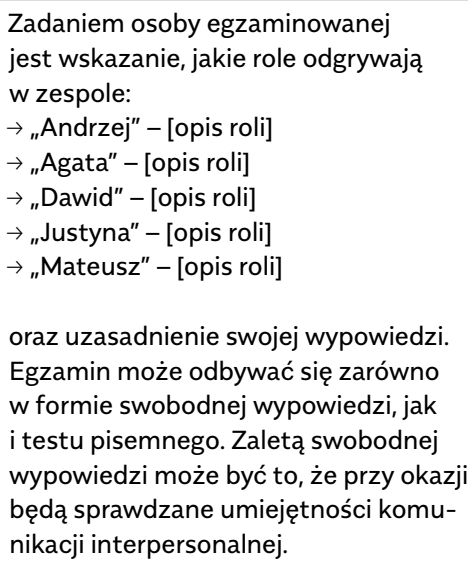 \\
\hline
\end{tabular}




\begin{tabular}{|c|c|c|}
\hline $\begin{array}{l}\text { 8. Kompeten- } \\
\text { cje medialne } \\
\text { Umiejętność } \\
\text { odpowiedzial- } \\
\text { nego odbioru } \\
\text { i interpretacji } \\
\text { komunikatów } \\
\text { medialnych }\end{array}$ & $\begin{array}{l}\text { Osoba egzaminowana ma za zadanie } \\
\text { obserwować film, który przedstawia } \\
\text { jedna po drugiej różnego rodzaju } \\
\text { wiadomości. }\end{array}$ & $\begin{array}{l}\text { Osoba egzaminowana powinna po } \\
\text { obejrzeniu filmu wskazać, które z prze- } \\
\text { kazanych wiadomości są: } \\
\rightarrow \text { faktami, } \\
\rightarrow \text { opiniami, } \\
\rightarrow \text { reklamą, } \\
\rightarrow \text { plotkami. } \\
\text { Ponadto wśród przekazywanych } \\
\text { informacji należy zidentyfikować styl } \\
\text { przekazu: } \\
\text { a) dramatyczny, } \\
\text { b) przesadzony. } \\
\text { Osoba egzaminowana ma wskazać, } \\
\text { czy dokonano manipulacji emocjami } \\
\text { odbiorcy w którymś z przekazów oraz } \\
\text { czy posługiwano się stereotypami. }\end{array}$ \\
\hline $\begin{array}{l}\text { 9. Zarządza- } \\
\text { nie konfliktem }\end{array}$ & $\begin{array}{l}\text { Osoba egzaminowana ma za zadanie } \\
\text { obserwować film, w którym przed- } \\
\text { stawiono konflikt w zespole. Lider } \\
\text { zespołu podejmuje próby rozwiąza- } \\
\text { nia konfliktu, rozmawiając z człon- } \\
\text { kami zespołu. Film można nakręcić } \\
\text { w różnych wersjach - wersje będą } \\
\text { różniły się: a) podłożem konfliktu; b) } \\
\text { imionami bohaterów (aby utrudnić } \\
\text { uczniom uczenie się na pamięć); c) } \\
\text { finałem sytuacji. W oglądanym filmie } \\
\text { różne postacie odgrywają różne role } \\
\text { w zespole. }\end{array}$ & $\begin{array}{l}\text { Osoba egzaminowana na podstawie } \\
\text { testu wielokrotnego wyboru ma za za- } \\
\text { danie wskazać odpowiedzi najtrafniej } \\
\text { podsumowujące dynamikę procesu } \\
\text { zarządzania konfliktem, zinterpreto- } \\
\text { wać zachowania członków zespołu, } \\
\text { ocenić trafność wybranych przez lidera } \\
\text { sposobów zarządzania konfliktem. }\end{array}$ \\
\hline $\begin{array}{l}\text { 10. Kreatyw- } \\
\text { ność w pra- } \\
\text { cy zawodowej } \\
\text { Kreatywność } \\
\text { i umiejętności } \\
\text { interpersonalne }\end{array}$ & $\begin{array}{l}\text { Celem tego zadania jest ocena } \\
\text { zdolności do tworzenia przez osobę } \\
\text { ocenianą kreatywnych rozwiązań. }\end{array}$ & $\begin{array}{l}\text { Miernikami kreatywności będą: } \\
\rightarrow \text { płynność - liczba rozwiązań, } \\
\rightarrow \text { giętkość - liczba kategorii rozwiązań, } \\
\rightarrow \text { oryginalność - statystyczna rzad- } \\
\text { kość występowania rozwiązań, } \\
\rightarrow \text { elaboracja - elegancja i precyzja } \\
\text { opisu rozwiązań. } \\
\text { Przy ocenie wyników kreatywności } \\
\text { niezbędne jest przeszkolenie egzami- } \\
\text { natorów oraz ocena zbiorowa (jury). } \\
\text { Kryterium „oryginalności” jest wysoce } \\
\text { subiektywne - zależy od wglądu } \\
\text { w szerszą pulę odpowiedzi udzielanych } \\
\text { przez osoby egzaminowane. Mierni- } \\
\text { kiem oryginalności jest statystyczna } \\
\text { rzadkość (1-5\% częstości występo- } \\
\text { wania wśród wszystkich udzielanych } \\
\text { odpowiedzi). }\end{array}$ \\
\hline
\end{tabular}




\begin{tabular}{|c|c|c|}
\hline $\begin{array}{l}\text { 11. Doskonale- } \\
\text { nie umiejętno- } \\
\text { ści zawodowych } \\
\text { Planowanie } \\
\text { własnego roz- } \\
\text { woju zawodo- } \\
\text { wego }\end{array}$ & $\begin{array}{l}\text { Osoba egzaminowana na podstawie } \\
\text { opisu fikcyjnej postaci ma zaplano- } \\
\text { wać jej rozwój zawodowy. Rozwią- } \\
\text { zanie zadania powinno polegać na } \\
\text { pisemnym sformułowaniu } 10 \text { reko- } \\
\text { mendacji dla postaci. Taka formuła } \\
\text { zadania umożliwia większą elastycz- } \\
\text { ność (w stosunku do wypowiedzi } \\
\text { we własnej sprawie). Jest to metoda } \\
\text { projekcyjna. }\end{array}$ & $\begin{array}{l}\text { Egzaminator ma przeanalizować treść } \\
\text { rekomendacji dla fikcyjnej postaci. }\end{array}$ \\
\hline $\begin{array}{l}\text { 12. Samoświa- } \\
\text { domość }\end{array}$ & $\begin{array}{l}\text { Osoba egzaminowana powinna doko- } \\
\text { nać oceny swoich silnych i słabych } \\
\text { stron. }\end{array}$ & $\begin{array}{l}\text { Ocena wykonania zadania odbywa } \\
\text { się na podstawie wnikliwości opisu } \\
\text { i uzasadnienia. Egzamin może zarówno } \\
\text { przyjąć formę swobodnej wypowiedzi, } \\
\text { jak i zostać ustrukturyzowany według } \\
\text { kwestionariusza egzaminacyjnego. }\end{array}$ \\
\hline $\begin{array}{l}\text { 13. Praca } \\
\text { zespołowa } \\
\text { Umiejętność } \\
\text { doboru człon- } \\
\text { ków zespołu }\end{array}$ & $\begin{array}{l}\text { Osoba egzaminowana ma do wyboru } \\
\text { charakterystyki ośmiu osób oraz opis } \\
\text { zadania. Powinna wskazać cztery, } \\
\text { które najlepiej nadają się do wykona- } \\
\text { nia danego zadania, oraz uzasadnić } \\
\text { swój wybór. Zadanie to może mieć } \\
\text { postać pisemną albo ustną. W przy- } \\
\text { padku odpowiedzi ustnej dodatkowo } \\
\text { sprawdzane byłyby umiejętności } \\
\text { komunikacji interpersonalnej. }\end{array}$ & $\begin{array}{l}\text { Ocena wykonania zadania odbywa } \\
\text { się na podstawie trafności wskazań } \\
\text { i doboru osób. Należy zadbać o to, aby } \\
\text { uniknąć zgadywania. Osoba egzamino- } \\
\text { wana powinna uzasadnić każdorazowo } \\
\text { swój wybór. }\end{array}$ \\
\hline $\begin{array}{l}\text { 14. Zdolność do } \\
\text { projektowania } \\
\text { (design } \\
\text { mindset) } \\
\text { Umiejętność } \\
\text { planowania } \\
\text { swojej pracy, } \\
\text { zarzqddzania } \\
\text { zasobami oraz } \\
\text { współpracy }\end{array}$ & $\begin{array}{l}\text { Sposób, w jaki zaprojektujemy } \\
\text { nasze otoczenie, ma wpływ na to, } \\
\text { jak postrzegamy świat oraz jak się } \\
\text { zachowujemy. Osoba egzaminowana } \\
\text { powinna w ramach tego zadania } \\
\text { zaprojektować proces, jaki wiąże } \\
\text { się z wykonywanym zawodem, np. } \\
\text { zaprojektować kurację dla sportowca, } \\
\text { który doznał kontuzji (dla zawodu } \\
\text { masażysta). W ramach zadania } \\
\text { należy dokonać wizualizacji procesu, } \\
\text { opisać zasoby, ramy czasowe, ryzyka } \\
\text { oraz sposoby angażowania osób } \\
\text { trzecich (współpraca). }\end{array}$ & $\begin{array}{l}\text { Ocena powinna odbywać się według } \\
\text { następujących kryteriów: } \\
\text { 1. kompletności przekazanych infor- } \\
\text { macji (uwzględnienie wszystkich } \\
\text { kluczowych elementów), } \\
\text { 2. komunikatywności s, } \\
\text { 3. precyzji opisu, } \\
\text { 4. realności opisanego planu. }\end{array}$ \\
\hline $\begin{array}{l}\text { 15. Komuni- } \\
\text { kacja } \\
\text { interpersonalna } \\
\text { Stosowanie za- } \\
\text { sad komunikacji } \\
\text { interpersonal- } \\
\text { nej }\end{array}$ & $\begin{array}{l}\text { Stosowanie zasad komunikacji inter- } \\
\text { personalnej powinno opierać się na } \\
\text { ściśle opisanym katalogu zachowań } \\
\text { pożądanych i niepożądanych. Osobie } \\
\text { egzaminowanej przedstawia się film, } \\
\text { na którym jego bohater w trakcie } \\
\text { prezentacji popełnia pewne błędy } \\
\text { w komunikacji interpersonalnej. } \\
\text { Zadaniem osoby egzaminowanej jest } \\
\text { ich identyfikacja. }\end{array}$ & $\begin{array}{l}\text { Ocena odbywa się na podstawie testu } \\
\text { pisemnego zawierającego listę poten- } \\
\text { cjalnych błędów w komunikacji. Osoba } \\
\text { egzaminowana ma za zadanie wskazać } \\
\text { błędy popełnione przez bohatera filmu. } \\
\text { Ponadto należy wskazać słabe i silne } \\
\text { strony bohatera filmu jako osoby } \\
\text { uczestniczącej w komunikacji interper- } \\
\text { sonalnej. }\end{array}$ \\
\hline
\end{tabular}




\begin{tabular}{|c|c|c|}
\hline $\begin{array}{l}\text { 16. Rozumie- } \\
\text { nie emocji + } \\
\text { kompetencje } \\
\text { międzykul- } \\
\text { turowe (+ ew. } \\
\text { język angielski) } \\
\text { Umiejętność } \\
\text { rozumienia } \\
\text { emocji innych, } \\
\text { empatia }\end{array}$ & $\begin{array}{l}\text { Celem zadania jest stwierdzenie, } \\
\text { w jakim stopniu osoba egzamino- } \\
\text { wana potrafi rozpoznawać i trafnie } \\
\text { określać emocje innych ludzi. Oprócz } \\
\text { samej identyfikacji emocji ważne jest } \\
\text { stwierdzenie, czy osoba egzamino- } \\
\text { wana umie właściwie reagować na te } \\
\text { emocje. }\end{array}$ & $\begin{array}{l}\text { Osoba egzaminowana analizuje sytu- } \\
\text { acje przedstawione za pomocą: } \\
\rightarrow \text { filmu, } \\
\rightarrow \text { komiksu, } \\
\rightarrow \text { opisu (narracji). } \\
\text { W opisanych sytuacjach występują } \\
\text { postacie wykonujące zadania związane } \\
\text { z egzaminowanymi kompetencjami } \\
\text { zawodowymi. W każdej z sytuacji } \\
\text { pojawia się interakcja, w której jeden } \\
\text { z bohaterów doświadcza pewnej } \\
\text { emocji (np. zawstydzenia, zakłopotania, } \\
\text { przestraszenia). Osoba egzaminowana } \\
\text { ma opisać (nazwać) tę emocję oraz: } \\
\text { a) opisać, czy osoba, której zachowanie } \\
\text { spowodowało tę emocję, zachowała się } \\
\text { poprawnie; } \\
\text { b) przedstawić, jeśli to potrzebne, inny } \\
\text { scenariusz (np. taki, w którym jedna } \\
\text { z osób nie została urażona). } \\
\text { Szczególnie warto podkreślić znacze- } \\
\text { nie kompetencji międzykulturowych } \\
\text { (kontakt z cudzoziemcem) oraz relacji } \\
\text { międzypokoleniowych (kontakt między } \\
\text { osobami młodą i starszą). }\end{array}$ \\
\hline
\end{tabular}

Źródło: opracowanie własne.

\section{Podsumowanie}

System edukacji opiera się na ponadczasowej zasadzie, którą Peter Drucker ujął tak: „What gets measured gets managed" ["Można zarządzać wszystkim, co można zmierzyć"] (Drucker 1954). Miał na myśli zjawisko orientacji zachowań ludzkich na kryteria oceniania. Innymi słowy, ludzie koncentrują swoją uwagę i energię na wykonywaniu działań, spełnianiu kryteriów, które podlegają ocenie. I na odwrót, jeśli dany obszar ludzkiej (potencjalnej) aktywności nie jest obiektem pomiaru i oceniania, staje się zaniedbywany. $Z$ taką sytuacją mamy do czynienia obecnie w systemach edukacji. $Z$ jednej strony, panuje powszechne przekonanie, że społeczeństwa i gospodarki potrzebują więcej innowacyjności, z drugiej zaś systemy edukacji nadal stawiają na te umiejętności i kompetencje, które zgodnie z wieloma prognozami nie będą potrzebne w przyszłości. Współczesny system egzaminów 
dość dobrze sparametryzował te obszary wiedzy i umiejętności, które w najbliższej przeszłości zostaną zastąpione przez sztuczną inteligencję. Aktywizacja i upodmiotowienie uczniów o ponadprzeciętnej kreatywności jest wielkim wyzwaniem dla systemów edukacji, które są jeszcze zakorzenione w XIX w. Tymczasem współczesny system edukacji raczej dyskryminuje uczniów kreatywnych. Winę ponosi m.in. istnienie podstawy programowej, która narzuca ramy dla sprawdzania wiedzy ucznia. Zmiany w systemach oświaty można by więc, zgodnie z obserwacją Petera Druckera, rozpocząć nie od zmian "wewnątrz" procesu edukacyjnego, lecz nieco przewrotnie, na jego końcu - tzn. przez zmianę sposobów, kryteriów oceniania i mierników. Mierniki te powinny dotyczyć szeroko rozumianej kreatywności uczniów. 



\section{Sam trening kreatywności nie wystarczy... \\ Uwagi o wspieraniu \\ kreatywności w szkole}

Anna Klimowicz

Wybitna kreatywność to bardziej zbiór cech osobowości i postawa niż efekt edukacji, ale kreatywność jako pomysłowość czy refleksyjny lub krytyczny sposób myślenia można rozwijać i kształtować w każdej szkole niezależnie od poziomu edukacji. Sprzyjają temu rozmaite drobne zmiany, niewymagające wielkiego nakładu kosztów. A przede wszystkim mają na to wpływ postawa i zaangażowanie nauczycieli, poszukiwanie przez nich innowacyjności w codziennej pracy i partnerskie traktowanie rodziców uczniów.

\section{Słowa kluczowe:}

cechy osób kreatywnych

szkolne przestrzenie

ćwiczenia fizyczne

nauczyciel jako mistrz

rola wychowawcy

formy tutoringu

alternatywne sposoby oceniania

współpraca z rodzicami 


\title{
Creativity training alone is not enough... Notes on supporting creativity at school
}

\author{
Anna Klimowicz
}

Outstanding creativity is more a collection of personality traits and attitude than the effect of education, but creativity as an ingenuity or a reflective or critical way of thinking can be developed and shaped in every school regardless of the level of education. Various minor changes, which do not require a lot of costs, are conducive to this. And above all, they are influenced by the attitude and commitment of teachers, searching for innovation in their everyday work and partner-like treatment of students' parents.

\section{Keywords:}

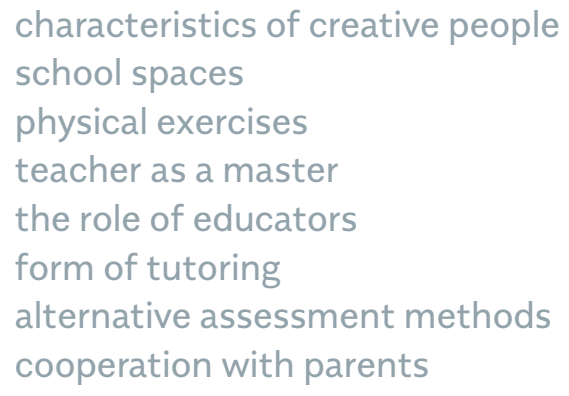




\section{Wybitnie kreatywni - czy takich uczniów lubi przeciętny nauczyciel?}

W latach 50. i 60. Frank Xavier Barron (Markov 2017), amerykański psycholog i filozof, uważany za pioniera psychologii kreatywności i badania ludzkiej osobowości, przeprowadził badania w Institute of Personality Assessment and Research [Instytut badań nad osobowością - przekł. red.] na Uniwersytecie w Berkeley. Zaprosił do campusu uniwersyteckiego reprezentantów różnych dziedzin, uznanych w swoich środowiskach za osoby wysoce kreatywne, m.in. architektów, naukowców, matematyków i pisarzy. Przeprowadził z nimi pogłębione wywiady i wszechstronne testy psychologiczne. Wyniki tych badań pozwoliły mu określić pewne wspólne cechy wyróżniające te osoby:

$\rightarrow$ duża pewność siebie,

$\rightarrow$ niezależność,

$\rightarrow$ skłonność do przeciwstawiania się konformizmowi,

$\rightarrow$ niekonwencjonalność,

$\rightarrow$ wysoki poziom intuicji,

$\rightarrow$ upodobanie do złożoności i wieloznaczności,

$\rightarrow$ wysoka tolerancja dla bałaganu i zamętu,

$\rightarrow$ spostrzegawczość, umiejętność znajdowania porządku i reguł w chaosie,

$\rightarrow$ odwaga i gotowość do podejmowania ryzyka w ważnym momencie,

$\rightarrow$ duża wytrzymałość, ponadprzeciętne zdrowie i poczucie humoru.

Wiele lat później badania kolejnych naukowców, tym razem z Uniwersytetu w Genewie (Fürst, Ghisletta, Lubart 2016), pozwoliły na sformułowanie podobnych spostrzeżeń dotyczących wspólnych cech u osób twórczych. Pogrupowano je w następujący sposób:

$\rightarrow$ plastyczność, czyli duża otwartość, ekstrawertyzm, energia, łatwość do inspirowania się;

$\rightarrow$ rozbieżność, czyli niezależne myślenie, niska spolegliwość i słaby poziom uważności, impulsywność;

$\rightarrow$ zbieżność, czyli ambicja, zdolność do ciężkiej pracy, precyzja, zmysł krytyczny.

Inne najnowsze badania podkreślają, że kreatywność wiąże się także z cechami, które nie są postrzegane jako pozytywne (Chamorro-Pre- 
muzic 2018). Osobom bardziej twórczym zdarza się częściej naruszanie niektórych z podstawowych form etycznego zachowania, np. łamanie reguł, podważanie autorytetów, ryzykanctwo, wywoływanie sytuacji konfliktowych i stresujących, niska tolerancja na nudę, konwencjonalność i bezczynność. Jeffrey Walczyk, Mark Runco, Sunny Tripp i Chris Smith (2008) dowiedli, że kreatywni kłamcy mogą osiągać wyższe wyniki w testach myślenia dywergencyjnego. Francesca Gino i Dan Ariely (2012) wykazali, że kreatywność może wiązać się z brakiem szczerości. W serii pięciu eksperymentów naukowcy stwierdzili m.in., że kreatywność pozwala skuteczniej niż inteligencja przewidywać nieszczere zachowanie, a także że osoby twórcze częściej zachowywały się w sposób nieuczciwy, równocześnie przejawiając większą zdolność do usprawiedliwiania tego typu zachowań. Wykazano również, że osoby wyjątkowo kreatywne są bardziej niż przeciętny człowiek skupione na sobie, wręcz usposobione narcystycznie. To nawet wzmacnia ich potencjał, ponieważ więcej myślą o swoich pomysłach, niż poświęcają swoją uwagę innym ludziom.

W sumie wszystkie te badania pokazują, że cechy kreatywnych osób to bardziej styl bycia, kwestia charakteru i pewna postawa, a nie efekt edukacji. Kreatywność to tak naprawdę zbiór różnych cech, które w połączeniu dają określony efekt. Czy każdy kreatywny człowiek osiąga sukces? Z pewnością nie. Wybitne wyniki w jakiejś dziedzinie wymagają przekraczania norm, czasami wręcz obsesji na jakimś punkcie, wytrwałości, wręcz samozaparcia, dyscypliny wewnętrznej. Z mnóstwa pomysłów naprawdę cenne są tylko te doprowadzone do końca.

Po przestudiowaniu biografii wielu sławnych twórców można zauważyć, że nie mieli łatwego życia w szkole. Dlaczego? Odpowiedź jest prosta - byli inni. Pochłonięci swoją pasją, zafascynowani wykreowaną przez siebie wizją, często krnąbrni, zwykle niedbający o dobre relacje $z$ innymi. Łączyła ich nienasycona żądza uczenia się i pogłębiania wiedzy, ale jedynie $w$ interesującej ich dziedzinie, niesłychany entuzjazm w poznawaniu coraz to bardziej złożonych problemów w wybranym wycinku rzeczywistości. Byli uparci w realizacji swoich celów i nawet liczne porażki nie były ich w stanie zniechęcić do dalszych poszukiwań. Wręcz przeciwnie - każdy błąd uznawali za krok naprzód. Mieli też ponadprzeciętną wyobraźnię, intuicję (coś na kształt "superlogiki", coś, co nagle przelatywało im przez głowę i kazało krzyczeć jak Archimedesowi „Eureka!"). 
Warto tu wspomnieć o Abrahamie Maslowie, który rozróżniał dwa rodzaje twórczości. W tej opierającej się na talencie istotne są zarówno wybitne zdolności, jak i cechy osobowe, których wykorzystanie daje $w$ rezultacie wybitne dzieła. Natomiast kreatywność związana z samorealizacją to twórczość, która może ujawniać się w rozmaitych dziedzinach życia i która jest dostępna dla każdego. Maslow podkreślał również, że proces twórczy składa się z dwóch etapów: pierwszy wiąże się z fascynacją pomysłem, natchnieniem, ideą; drugi zaś to opracowywanie pomysłu, wymagające cierpliwości, skupienia i motywacji. Wiele osób zatrzymuje się na etapie pierwszym, znamy doskonale określenie "słomiany ogień". Tymczasem autentyczna, wybitna twórczość to 5\% talentu, a 95\% ciężkiej pracy, jednak takiej, która daje poczucie zadowolenia i satysfakcji. Według Maslowa "kreatywność jest to radość i otwarcie się na doświadczanie" (Nęcka 2001, s. 23).

Gdyby potraktować te wszystkie spostrzeżenia jako wskazówkę do pracy nad kształtowaniem kreatywności u uczniów, to należałoby być nauczycielem otwartym, wszechstronnym, tolerancyjnym, w dodatku dość wymagającym i konsekwentnym, który proponuje swoim uczniom taką formę uczenia się, przy jakiej dobrze się bawią. Tylko pomarzyć, aby szkolne lekcje przypominały zajęcia w Centrum Nauki Kopernik, nauczyciele - charyzmatycznego Johna Keatinga, a budowanie szkolnej atmosfery wzorowano na słynnej Summerhill. Frank Zappa, słynny amerykański muzyk rockowy, powiedział, że „Umysł jest jak spadochron. Nie działa, jeśli nie jest otwarty"1.

Aby w szkole zapoczątkować zmiany, których celem jest rozbudzenie kreatywności uczniów, trzeba się samemu otworzyć, znaleźć w sobie zapał i zacząć nim „zarażać” innych. Przełamać różne bariery, najpierw te mentalne.

\section{Jak jest}

Moje długoletnie doświadczenia zawodowe, wielorakie kontakty z nauczycielami, uczniami i rodzicami pozwalają na sformułowanie opinii, że w polskich szkołach nie ma zbyt wielu twórczych nauczycieli. Przeważająca liczba to tzw. rzemieślnicy, powielający w codziennej pracy własne doświadczenia z bycia uczniem, korzystający z gotowych kon- 
spektów, usiłujący wtłoczyć do uczniowskich głów porcje wymaganej podstawą programową wiedzy. $Z$ reguły nauczyciele koncentrują się na utrzymaniu dyscypliny, straszą egzaminami, szlifują wypełnianie testów pod klucz. Preferują nauczanie tradycyjne, tzw. frontalne, czyli przy tablicy, oraz zadawanie uczniom mnóstwa pracy domowej. Żyją pod presją, śledzą rankingi, czują się obarczeni odpowiedzialnością za niemal każdą porażkę ucznia. Jakakolwiek próba wprowadzenia innowacyjnych rozwiązań wywołuje u nich obawę. Zwykle są przekonani, że podobne zmiany w ich szkołach "nie przejdą" lub mówią, że "nie [mają] czasu na te rzeczy, bo uczniowie muszą zdać egzamin"2. Wielu nauczycieli deklaruje znajomość aktywizujących metod i technik nauczania, jednak najczęściej ich nie stosuje, ponieważ często wymagają więcej czasu niż standardowe 45 minut lekcji, a także zupełnie innego niż przyjęty sposobu budowania relacji i porozumiewania się z uczniami. Wymagają również umiejętności podsumowywania wykonywanych przez uczniów zadań, omawiania ich, wyciągania wniosków. Nauczyciele nie są przygotowani, aby być trenerami czy też coachami swoich uczniów.

\section{Uczeń potrzebuje mistrza}

Wybitni ludzie nie wyrastają w izolacji od otoczenia, przeciwnie w okresie, kiedy dojrzewają, w ich środowisku znajdują się osoby, które są dla nich autorytetami, odgrywają rolę doradców i przewodników. Każdy wielki geniusz miał swojego mistrza, który wskazał mu drogę (Platon Sokratesa, Aleksander Wielki Arystotelesa, a Bill Gates celowo angażuje wybitne umysły jako swoich doradców). Wspaniale jest, gdy uczeń przewyższy swego mistrza. Gdyby nie było to prawdą, świat stanąłby w miejscu. Tymczasem niektórzy nauczyciele traktują zdolnych uczniów jako zagrożenie - boją się kompromitacji na lekcji - taki uczeń może wytknąć im błąd (a przecież oni chcą być nieomylni), obawiają się przyznać, że sami niespecjalnie lubią się uczyć - a stawiane przez dociekliwego ucznia pytania bywają niewygodne i zmuszają do wyjścia poza schemat lekcji opracowany przez nich przed laty.

Takie wypowiedzi często słyszałam w czasie prowadzonych przez siebie zajęć warsztatowych dla nauczycieli. Nawet kiedy podczas zajęć nauczyciele w zespołach wymyślili mnóstwo ciekawych pomysłów wzbogacających standardowe zajęcia dla uczniów, po ich zaprezentowaniu na forum grupy tak właśnie je komentowali i twierdzili, że bardzo im się podobają, ale nie jest to możliwe, aby mogli je zrealizować. 
Nauczyciel, który chce być mistrzem, musi więc sam dbać o swój rozwój, starać się wiedzieć więcej i szukać nowych rozwiązań, wychodzić poza szablon. Zdolni uczniowie stanowią dla dobrego nauczyciela wyzwanie - dzięki nim można na nowo rozbudzić stare pasje albo wreszcie znaleźć partnera, z którym wspólnie można się fascynować odkrywaniem tajemnic świata. Nauczyciel powinien być profesjonalnym doradcą, który pomoże utalentowanemu uczniowi w realizacji jego wizji i osiąganiu wyznaczonych celów. Odkrywanie i wspieranie cudzych talentów może przynieść dużą satysfakcję - być może nasz uczeń zostanie ministrem lub prezydentem, a może wynalazcą czy mistrzem świata. Dlatego warto zająć się nim już dziś. To wymaga trochę wysiłku ze strony nauczyciela i obudzenia jego kreatywności. Uczeń zdolny szybko wykonuje polecenia, które innym uczniom zajmują dużo czasu - trzeba więc dla niego wymyślać zadania trudniejsze, ale nie nudne! Takie, które wymagają myślenia, refleksji, wyobraźni - utalentowani nie lubią żmudnej dłubaniny - mogą głowić się przez pół nocy nad kolejnym sposobem rozwiązania zadania z fizyki, ale dodawanie "słupków" czy przepisywanie regułek, wkuwanie na pamięć definicji tylko ich zniechęci. Uczniów trzeba chwalić - jeśli docenimy ich sukcesy (nawet bardzo drobne), będą starali się osiągnąć jeszcze więcej. Uczniowie szczególnie uzdolnieni są także bardziej wrażliwi - należy o tym pamiętać i cenić i szanować tę wrażliwość, a nie starać się ją stłumić. To nic złego, jeśli nasz uzdolniony jest indywidualistą i ma własne zdanie, własny sposób oceny zdarzeń, ludzi i ich dzieł - pozwólmy mu być krytycznym - to domena młodości, że widzi się wszystko „czarno" lub "biało", ale też podajmy jego sposób widzenia w wątpliwość, znajdźmy argumenty, które będą mu nasuwały inny sposób myślenia. Lekcje powinny być okazją do wymiany poglądów - uczeń, który ma inne zdanie niż wszyscy, może wprowadzić "ożywczy wiatr" i nakręcić wspaniale dyskusję.

Stosując na lekcjach pracę w grupach i dobrze dobierając zespoły, możemy znakomicie wykorzystać zdolniejszych uczniów, by podzielili się swoją wiedzą i umiejętnościami z innymi. Z pewnością - odpowiednio zmotywowani - zrobią to chętnie i mogą w roli uczącego innych wypaść lepiej od nauczyciela.

Nauczyciel, aby kształtować kreatywność swoich uczniów, nie musi być wielkim innowatorem, wystarczy, aby był poszukujący. Musi sam lubić się uczyć i być otwarty na nowości. Kiedy będzie miał w sobie 
poczucie wolności, swobody, niezależności, udzieli się to jego uczniom. Nie oznacza to przekraczania ustalonych zasad społecznych i prawa, ale stwarzanie atmosfery wolnej od napięć psychicznych. Jest mnóstwo literatury na temat rozwijania twórczego myślenia, wiele publikacji na temat efektywnego nauczania i prowadzenia ciekawych lekcji, gier i zabaw edukacyjnych. Wydawnictwa edukacyjne "produkują" do każdego przedmiotu poradniki dla nauczycieli z inspirującymi scenariuszami lekcji, z opisami aktywizujących metod i technik nauczania. Internet pełen jest propozycji wzbogacających warsztat pracy nauczyciela. Trzeba przestać napędzać rywalizację między uczniami, nie porównywać ich między sobą. Zaakceptować, że każdy jest inny, każdy ma inne możliwości intelektualne. Zacząć nagradzać również sam wysiłek, a nie tylko rezultat. Inspirować uczniów, ale nie wykonywać za nich ich pracy. $\mathrm{Na}-$ wet jeśli coś zrobią gorzej, słabiej gdzieś wypadną, to nie trzeba na siłę ich wyręczać, pisać im tego, co mają publicznie powiedzieć, wykonywać za nich prac wysyłanych na konkursy, przygotowywać za nich gazetek. Dobry nauczyciel to taki, który nie jest nadopiekuńczy, ale wspierający. Dziś celem, na którym mają się koncentrować nauczyciele, powinno być przekazywanie sposobów najbardziej efektywnego uczenia się, uczenie umiejętności przetwarzania i wykorzystywania informacji, a nie wtłaczanie encyklopedycznej wiedzy. Nauka ma skłaniać uczniów do samodzielnego myślenia, czyli do tego, co będzie im najbardziej potrzebne, by byli w stanie samodzielnie lub w zespole rozwiązywać coraz bardziej złożone problemy. Potrzebujemy dziś takich form edukacji, które będą rozwijały kreatywny potencjał ludzkiego mózgu.

\section{Drobne zmiany w przestrzeni szkolnej}

Właściwie zaaranżowane przestrzenie szkolne mogą zwiększyć wydajność i kreatywność uczniów nawet o kilkanaście procent. Zła aranżacja sprawi, że staną się drażliwi, agresywni lub apatyczni i ociężali. Przy okazji remontu można wprowadzić do szkoły kolorystykę sprzyjającą wydajności i kreatywności przebywających w niej osób. Pastelowe zielenie i błękity stymulują kreatywność. Nic nie stoi na przeszkodzie, aby w zgodzie z wynikami wielu eksperymentów i badań stworzyć uczniom przestrzeń sprzyjającą ich dobremu samopoczuciu. Co roku można np. ogłaszać w szkole konkurs na najciekawiej urządzoną klasopracownię warunek - aranżacja pomieszczenia ma być przygotowana samodzielnie przez uczniów. Można też zaangażować rodziców. Z niepotrzebnych 
domowych gratów i gadżetów wygospodarować cuda, które po odnowieniu zamienią nieprzyjazne, przypominające koszary szkolne wnętrza w pomieszczenia sprzyjające pracy twórczej.

W każdej szkole można również zadbać o rośliny, które zmieniają wnętrza nie do poznania. Inspiracją mogą być dziesiątki stron internetowych prezentujących pomysły projektantów - stare skrzynie czy beczki, koszyki wiklinowe zamiast tradycyjnych doniczek - pomysłów są setki. Kwiaty odznaczają się nie tylko walorami estetycznymi, mają też korzystny wpływ na zdrowie. Roślinność dobrze wpływa na nasze samopoczucie, pochłania szkodliwe substancje, poprawia wilgotność powietrza, a co najważniejsze, sprawia, że czujemy się zrelaksowani. Przy okazji uczniowie mogą zająć się zazielenieniem szkoły metodą projektu i wykazać się kreatywnością. W ramach projektu mogą zadbać o przestrzeń wokół szkoły - założyć ogród szkolny lub opracowywać własne wystawy plenerowe na różne interesujące ich tematy. W ten sposób szkoła może zaistnieć w lokalnym środowisku - każdy przechodzień będzie mógł podziwiać dorobek uczniów. Na takich wystawach uczniowie mogą przecież prezentować własne prace plastyczne, fotograficzne i literackie. Jeśli wokół szkoły znajdują się jakieś niezbyt ciekawe płaszczyzny murów, można oddać je we władanie szkolnym grafficiarzom - ozdobią w ciekawy sposób śmietniki, stare komórki, płoty itp. Projekt jest w ogóle świetną, wieloaspektową metodą. Dzięki realizacji zadań projektowych oprócz wiedzy i doświadczeń uczniowie nabywają wiele umiejętności, stają się bardziej samodzielni i rozwijają poczucie sprawstwa. Warto wymagać od nauczycieli, aby dobrze poznali metodę projektu i spróbowali opracować harmonogram choćby jednego na rok projektu ogólnoszkolnego.

Podobno muzyka stanowi dobre wsparcie dla procesów myślowych i uczenia się. Godne polecenia są utwory klasyczne i muzyka relaksacyjna. W serwisie YouTube można znaleźć wiele składanek muzycznych, które korzystnie wpływają na samopoczucie i usprawniają pracę mózgu. Wykorzystajmy tego typu muzykę w czasie przerw. Wyjaśnijmy uczniom jej działanie. Zachęćmy ich również do ćwiczeń grupowych na szkolnych korytarzach - ćwiczeń, które usprawniają pracę obu półkul mózgowych, ułatwiają percepcję (np. zestawy opracowane przez dra Paula Dennisona). Takie ćwiczenia przydadzą się uczniom w każdym wieku, nie tylko tym najmłodszym. Skorzystają z nich także nauczyciele - zamiast występować w roli strażnika - rozruszają się i uelastycznią. Ćwiczenia fizyczne w ogóle mają zbawienny wpływ na umysł. Skoro wiemy, że ruch 
sprzyja dobrej pracy mózgu, warto rozpoczynać lekcje od rozgrzewek fizycznych i umysłowych. Czas też odświeżyć ćwiczenia śródlekcyjne, onegdaj wymagane w każdej szkole, a teraz w wielu zapomniane.

W wielu szkołach funkcjonuje radiowęzeł. To doskonałe medium dla początkujących dziennikarzy. Zachęćmy tych, którzy czują powołanie do opracowywania i nadawania cotygodniowych kilkuminutowych audycji, do wygłaszania cyklicznych miniwykładów czy prelekcji na interesujące ich tematy.

Należy też zadbać, aby uczniowie mieli jak najwięcej okazji do wychodzenia ze szkoły na zewnątrz oraz spotkań z ciekawymi osobami. Muzea, teatr, kino, galerie sztuki, ogrody botaniczne, miejsca pracy, urzędy, domy starości - im więcej miejsc pozna młody człowiek, tym więcej będzie wiedział o świecie. Z tym że każda wycieczka i spotkanie powinny być wcześniej zaplanowane, przemyślane, z odpowiednimi dyspozycjami do wykonania zadań dla uczniów, a po każdej wizycie nauczyciel powinien zebrać spostrzeżenia uczniów, poprosić o podzielenie się wrażeniami, odczytanie kart pracy, pokazanie zrobionych przez uczniów zdjęć, a następnie szczegółowo wyprawę omówić, podsumować.

Istotną zmianą w szkole powinno być ułożenie planu lekcji w sposób najbardziej korzystny dla uczniów, nie dla nauczycieli. Chodzi o takie pogrupowanie przedmiotów, aby spełniały kryteria oceny rozkładu zajęć, oparte na rekomendowanych przez sanepid warunkach higienicznej organizacji pracy z uczniem.

\section{Alternatywne sposoby oceniania}

Oceny szkolne są niezwykle ważne i mają nie do końca przewidywalne skutki, czasem bardzo odsunięte w czasie. Warto, by wszyscy nauczyciele poznali zasady autentycznego oceniania i potrafili konstruować tabele kryteriów oceniania, które w zrozumiały dla uczniów sposób komunikują, co jest ważne w uczeniu się, oraz zawierają informację zwrotną, co uzupełnić, poprawić, jeśli uczniowi zależy na dobrej ocenie. Przemyślaną strategią nauczania, prowadzącą do zwiększenia motywacji uczniów i przejęcia przez nich aktywności w procesie uczenia, jest ocenianie kształtujące. W ocenianiu kształtującym (OK) chodzi o nauczenie uczniów refleksyjności, rozważności, umiejętności stawiania pytania, skłonności raczej do prowadzenia dialogu niż podejmowania za innych autorytarnych decyzji. NaCoBeZU (czyli na co będę zwracał uwagę) - to termin, który został ukuty na potrzeby OK, aby określić 
to, co najważniejsze w treściach przekazywanych w czasie zajęć. Nauczyciel stawia pytania kluczowe, które skłaniają do myślenia, angażują uczniów do poszukiwania odpowiedzi. Autorami pytań mogą być również sami uczniowie. Assessment for learning to również sztuka prowadzenia dialogu. Faktycznie, dla nauczycieli przyzwyczajonych do jednostronnej komunikacji w klasie jest to spora ekwilibrystyka - zadawać pytania, na które uczniowie będą chcieli i umieli odpowiadać, umieć samemu odpowiedzieć na podchwytliwe, drążące pytania uczniów, a czasami przyznać się, że się czegoś nie wie. Taka lekcja wymaga ze strony nauczyciela przemyśleń, zaplanowania czasu, przyjęcia postawy, że można czegoś nie wiedzieć. Lekcje prowadzone według recepty $z$ assessment for learning są pouczającą rozmową, a nie wygłaszaniem sądów ex cathedra. Uczą myślenia. A jedynie myślący ludzie są w stanie zmieniać rzeczywistość na lepsze i o to nam wszystkim pracującym z dziećmi i młodzieżą powinno chodzić.

\section{Wychowawca - liderem}

Istotną rolą w szkole jest funkcja wychowawcy. Od niego w dużej mierze zależy, czy uczniowie będą się czuli bezpiecznie i swobodnie ze sobą, w jakim stopniu będą zmotywowani do nauki. Zbudować z grupy przypadkowo zebranych uczniów efektywny zespół klasowy nie jest łatwo. Udane interakcje między uczniami w szkole są podstawą udanych interakcji w późniejszych miejscach ich pracy. Kto pracuje w dobrym zespole, uczy się od innych uczestników lepiej, z większym zaangażowaniem i motywacją. Szybciej też potrafi wypracować poczucie własnej wartości - bez którego nie sposób być kreatywnym. W niewielu szkołach odbywają się autentyczne zajęcia poświęcone sprawom wychowawczym. Uczniowie, a i sami nauczyciele przyznają, że często ta jedna $w$ tygodniu godzina przeznaczona dla wychowawcy jest wykorzystywana do nadgonienia zaległości z przedmiotu lub poświęcona na rozmowę (czytaj: monolog nauczyciela) dotyczącą nieusprawiedliwionych nieobecności, omówienia zatargów z innymi nauczycielami, prób rozwikłania klasowych sporów. Celem pierwszych lekcji wychowawczych ma być przede wszystkim dobre wzajemne poznanie się uczniów, a także nauczyciela. To daje szansę, że stworzą zespół, w którym szybciej będzie można ustalić listę wiążących norm grupowych, trafniej wybrać osoby reprezentujące klasę na forum szkoły i prędzej zbudować atmosferę zaufania, bez której nie ma mowy 
o otwartej komunikacji, niezbędnej podczas zajęć. Takie zajęcia powinny uwzględniać proces grupowy, który odbywa się w każdym zespole zadaniowym (a takim zespołem jest właśnie klasa). Należy je prowadzić metodami aktywizującymi pracę ucznia, kłaść duży nacisk na współpracę w grupie i na udział we wszelkiego typu dyskusjach, podczas których dla nauczyciela ważniejsze jest stawianie pytań niż udzielanie odpowiedzi (bo w sferze moralnej tych prawidłowych może być więcej). Celem kolejnych lekcji wychowawczych powinno być budzenie wrażliwości wobec innych ludzi i otaczającego nas świata, refleksja nad własną osobą i pełnioną przez siebie funkcją w społeczeństwie. Młody człowiek najczęściej pozostaje sam ze swoimi wątpliwościami, pytaniami, problemami. Próbuje je, nie zawsze w trafny sposób, rozwiązać z pomocą rówieśników, równie zagubionych i, wbrew pozorom, niepewnych siebie. Warto proponować uczniom tematy zajęć, które koncentrują się wokół spraw codziennych, takich jak budowanie własnego poczucia wartości, nawiązywanie relacji z innymi, rozwijanie umiejętności komunikacyjnych, wyrażanie swojego zdania, rozwiązywanie trudnych sytuacji, zajmowanie stanowiska wobec różnych dylematów. Ważne są także sprawy profilaktyki, stylu życia, który zapewnia dobre zdrowie, umiejętności uczenia się i samorozwoju. Kiedy nauczyciel wysyła sygnały życzliwego zainteresowania problemami młodego człowieka, daje mu wyraźnie odczuć, że jest skłonny zaufać jego słowom i że jednocześnie sam jest wart zaufania, staje się dla niego autentycznym autorytetem $w$ wielu sprawach i przewodnikiem po najbliższym dla ucznia świecie.

\section{Współpraca z rodzicami na rzecz podniesienia poziomu kreatywności w szkole}

Nauczyciel, który chce osiągnąć pozytywne efekty w swojej pracy, powinien traktować rodziców w miarę możliwości (bo w życiu spotykamy się z różnymi postawami, stylami życia, patologiami) jako sojuszników. Ważna jest ścisła współpraca z rodzicami i to nie tylko w przypadku trudnych sytuacji. Spotkania z rodzicami powinny przełamywać stereotypowe, tradycyjne schematy. Wielu nauczycieli jest zbulwersowanych roszczeniową postawą rodziców. Jednak, gdyby sami czuli się pewnie w materii wychowywania, znali podstawy psychologii i zasady efektywnej komunikacji, być może uniknęliby nieprzyjemnych sytuacji, wiedząc, w jaki sposób i do czego przekonać rodziców. W końcu to 
rodzice odpowiadają prawnie za swoje dzieci i to oni ponoszą wszelkie konsekwencje związane z ich wychowywaniem, nawet do końca życia. Powinni wiedzieć, o czym i dlaczego nauczyciel rozmawia z ich dziećmi, czego ich uczy, w jaki sposób z nimi pracuje. Otwarty na innych nauczyciel może wykorzystać osiągnięcia niektórych rodziców i zaprosić na spotkanie z uczniami, aby opowiedzieli o swojej pracy, zainteresowaniach, pochwalili się sukcesami. Wielu rodziców wykonuje interesujące zawody, posiada różne umiejętności i pasje. Warto stworzyć im możliwości, aby podzielili się z młodzieżą tym, co potrafią, i opowiedzieli, w jaki sposób pracują, co ich motywuje, co daje im satysfakcję. I naprawdę nie muszą to być celebryci i krajowe tuzy. W ramach wymaganych pedagogizacji nauczyciele w szkole zainteresowanej rozwijaniem kreatywności powinni przygotować dla rodziców cykl wykładów z prezentacjami multimedialnymi dotyczącymi m.in. funkcjonowania mózgu, komunikacji interpersonalnej, najbardziej efektywnych sposobów uczenia się, wpływu diety i aktywności fizycznej na pracę szarych komórek. Wiele satysfakcji przynoszą organizowane wspólnie z rodzicami rozmaite imprezy szkolne na rzecz rozwijania szeroko rozumianej kreatywności.

\section{O jaki rodzaj kreatywności chodzi?}

Ludzki świat przyśpieszył. Każda nowa wiadomość obiega glob w zaledwie kilka sekund. Z jednej strony, mamy nadmiar wszystkiego: towarów, usług, informacji. Z drugiej - nadal w rozmaitych miejscach ludzie żyją na skraju nędzy, brakuje im możliwości zaspokojenia podstawowych potrzeb. Większość ludzi porusza się w ciągłym pośpiechu, w dezorientującym zgiełku informacyjnym, w pogoni za niezdefiniowanym szczęściem, sukcesem i sławą. Jednocześnie ludzkość stoi na skraju globalnej katastrofy. Ciągły rozwój technologii w różnych obszarach sprawił, że zasoby naturalne Ziemi są na wyczerpaniu i wielu naukowców prognozuje, że za nieco ponad 10 lat, przy tym samym tempie rozwoju co dotychczas i tak źle rozumianym przez najbardziej wpływowych decydentów (vide: stojących na czele państw i korporacji), nastąpi koniec świata - przynajmniej takiego, jaki znamy dzisiaj. Dlatego powinniśmy w czasach współczesnych w związku kreatywnością postawić pytanie, o jaką kreatywność nam chodzi. W jakim kierunku, my dorośli-rodzice i nauczyciele - chcemy kształtować bystrość umysłów młodych ludzi? Komu i czemu mają w przyszłości służyć ich pomysły? Czy efekt ich 
twórczości będzie wartościowy, znaczący? Czy będą potrafili przetworzyć świadomie zastaną przez siebie rzeczywistość, aby otaczający nas świat uczynić lepszym? 

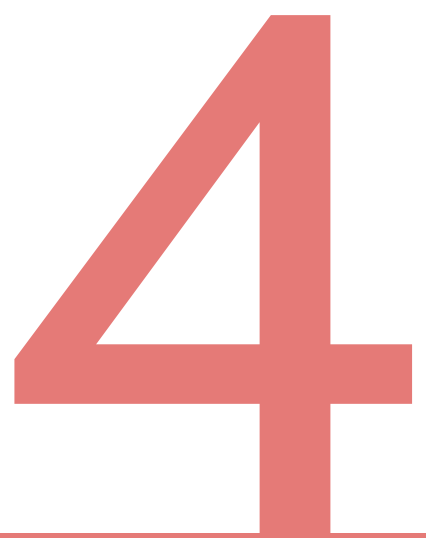


\section{Kreatywność na rynku pracy}




\section{Znaczenie i sposoby rozwoju kreatywności w gospodarce cyfrowej}

Dorota Roszkowska

W gospodarce cyfrowej, w której technologie informacyjno-komunikacyjne umożliwiają niemal każdemu korzystanie z nieograniczonego źródła inspiracji dzięki wykorzystaniu zasobów internetu i sieci społecznościowych, to niestandardowy sposób używania danych i informacji decyduje o uzyskiwanych przewagach konkurencyjnych i innowacyjnych. Z tego względu wśród kompetencji cyfrowych kreatywność ma szczególne znaczenie. Adaptacja narzędzi cyfrowych już na etapie edukacji może pozwolić na zwiększenie wydajności i satysfakcji z wykonywanej pracy przyszłych pracowników. Rozdział przedstawia przykładowe narzędzia cyfrowe, które mogą być inspiracją do wdrożenia nowych sposobów rozwoju kreatywności u uczniów, a także w środowisku pracy. 


\section{Importance and ways of developing creativity in the digital economy}

Dorota Roszkowska

In the digital economy, where information and communication technologies enable almost everyone to use an unlimited source of inspiration, through the use of Internet resources and social networks, the non-standard way of using data and information determines the competitive and innovative advantages. For this reason, creativity is of particular importance among the catalog of digital competences. Adaptation of digital tools already at the stage of education, may allow to increase the efficiency and satisfaction of the work of future employees. The publication contains a description of examples of digital tools that can be an inspiration to implement new ways of developing creativity among students, as well as in the work environment.

\section{Keywords:}

digital economy

digital skills 


\section{Wprowadzenie}

Ideacja, którą można też określić jako etap kreacji, stanowi pierwszy element procesu innowacyjnego. Przełomowe innowacje nie powstają bez twórczego, nieschematycznego myślenia i działania. Można zatem stwierdzić, że nie ma innowacji bez kreacji, a kreacji bez kreatywności. Kreatywność to przykład kompetencji przyszłości, która w gospodarce cyfrowej stanowi kluczową przewagę konkurencyjną. Można stwierdzić, że jest paliwem innowacyjności, która stanowi główny czynnik współczesnego wzrostu gospodarczego. Kreatywność można rozwijać i stymulować. Pobudzanie kreatywności z wykorzystaniem odpowiednich technik może pozytywnie wpłynąć na działania innowacyjne.

W gospodarce cyfrowej, w której technologie informacyjno-komunikacyjne umożliwiają niemal każdemu korzystanie z nieograniczonego źródła inspiracji poprzez wykorzystanie zasobów internetu i sieci społecznościowych, to właśnie niestandardowy sposób korzystania z danych i informacji decyduje o uzyskiwanych przewagach konkurencyjnych i innowacyjnych. Wzrost zaawansowania procesów automatyzacji i robotyzacji sprawia, że wykonanie powtarzalnych czynności wymaga coraz mniejszego zaangażowania człowieka. Sztuczna inteligencja i uczenie maszynowe wpływają w znacznym stopniu na strukturę rynku pracy i kompetencji poszukiwanych u pracowników. Wymusza to także zmiany w programach kształcenia instytucji edukacyjnych, które za pomocą analizy zachodzących trendów społecznych, gospodarczych i technologicznych, a także ścisłej współpracy z pracodawcami powinny dostosowywać swoją ofertę edukacyjną do wyzwań pracowników przyszłości. Wydaje się, że aktualny stan oferty kształcenia instytucji edukacyjnych w większości nie nadąża za potrzebami rynku. Duża liczba dostępnych na rynku odpłatnych kursów i szkół prywatnych, oferujących szkolenia z zakresu kompetencji cyfrowych, kodowania, robotyki etc., pokazuje, że oferta edukacyjna publicznych instytucji edukacyjnych jest mało elastyczna. Warto także zauważyć, że gospodarka cyfrowa $z$ jednej strony zmienia strukturę popytu na kompetencje pracowników, z drugiej udostępnia narzędzia, dzięki którym nabycie nowych kompetencji może stać się łatwiejsze. Narzędzia cyfrowe pozwalają na zwiększenie efektywności przyswajania nowych kompetencji, co w dobie dynamicznych zmian na rynku pracy ma duże znaczenie.

Niniejszy rozdział ma na celu określenie znaczenia kreatywności w gospodarce cyfrowej i katalogu kompetencji cyfrowych. Zostaną 
w nim także przedstawione przykłady narzędzi cyfrowych, które mogą stanowić inspirację do wdrożenia nowych sposobów rozwoju kreatywności wśród uczniów, a także w środowisku pracy.

\section{Rola kreatywności w gospodarce cyfrowej. Wyzwania kompetencyjne}

Rewolucja technologiczna napędzana rozwojem technologii informacyjno-komunikacyjnych wpłynęła na zmianę paradygmatu funkcjonowania gospodarki, tworząc nowe reguły gry rynkowej. Istotnie zmieniły się warunki funkcjonowania przedsiębiorstw, rynku pracy i edukacji. Początek wyżej wymienionych zmian dało się zauważyć już pod koniec lat 80., kiedy to mogliśmy mówić o początku rewolucji informatycznej, objawiającej się spadkiem gospodarczego znaczenia zasobów surowcowych i wzrostem znaczenia informacji, wiedzy i intelektu, stanowiących kluczowe zasoby tzw. nowej gospodarki. W takich warunkach gospodarczych technologie umożliwiające efektywne generowanie, przetwarzanie i transfer danych i informacji stały się nowym paliwem wzrostu. Nastąpiły też zmiany struktury popytu na kompetencje pracowników. Efektywność, innowacyjność i konkurencyjność sektora przemysłu, przechodzącego dzięki zastosowaniu technologii cyfrowych tzw. czwartą rewolucję przemysłową, a także każdego innego obszaru gospodarki, warunkowane są odpowiednimi kompetencjami pracowników, którzy będę potrafili wykorzystać nowe możliwości. Charakterystyczne dla gospodarki cyfrowej poza informatyzacją i cyfryzacją jest kluczowe znaczenie internetu, dostęp do zasobów sieciowych i umiejętność twórczego opracowywania nowych rozwiązań i produktów oraz budowania sieci kontaktów. Potwierdzają to sukcesy firm opierających swój model działania na zasadach tzw. ekonomii dostępu i współdzielenia (sharing economy). W dobie transformacji cyfrowej to kompetencje cyfrowe pracowników będą decydować o sukcesie przedsiębiorstw i gospodarek. Skuteczna transformacja cyfrowa gospodarki nie jest możliwa bez nowoczesnego i efektywnego systemu edukacji i szkolnictwa, kształcących kreatywnych pracowników potrafiących skutecznie wykorzystać nowe technologie i adaptować się do szybko zmieniającego się otoczenia gospodarczego i społecznego.

Uwzględniając aktualne warunki i możliwości tworzenia nowych rozwiązań, można wysunąć tezę, że w erze cyfrowej kreatywność staje się kluczowym czynnikiem przewag konkurencyjnych. Wzrasta też zna- 
czenie zewnętrznych (znajdujących się poza przedsiębiorstwem) źródeł wiedzy, technologii, innowacji, a także zdolności firm do integrowania, dalszego rozwijania i szybkiego wdrażania innowacyjnych rozwiązań w dużej skali. Źródłem kreatywności i innowacyjności w gospodarce i społeczeństwie są działania ludzi uwarunkowane ich potencjałem twórczym oraz czynnikami technologicznymi, ekonomicznymi i socjologicznymi (Zorska, Molęda-Zdziech, Jung 2014, s. 3-24). John Howkins zauważył, że kreatywność sama w sobie nie jest dobrem w kategoriach ekonomicznych, ale jej produkty mogą nim być (Howkins 2014). Produktem kreatywności jest innowacja, która ma już wymierną wartość ekonomiczną. Choć pomysł i wdrożenie rynkowe dzieli bardzo duża luka, to bez fazy koncepcyjnej nie może nastąpić rozwój produktu i jego finalne wdrożenie. Stwierdzić zatem można, że gospodarka cyfrowa kształtuje popyt na kompetencje cyfrowe, które zgodnie z prognozami będą stanowiły o umiejętności odnalezienia się pracowników i obywateli w nowym otoczeniu gospodarczym.

\section{Kompetencje w erze cyfrowej. Rola kreatywności}

Termin „umiejętności i kompetencje cyfrowe” jest bardzo szeroki i trudny do precyzyjnego określenia. Jednoznaczne wskazanie katalogu kompetencji cyfrowych budzi spory i wątpliwości (Meyers, Erickson, Small 2001; Prensky 2001). Organizacje międzynarodowe oraz instytuty badawcze i społeczne podejmują próby stworzenia tzw. ram kompetencji cyfrowych (Cachia, Ferrari, Ala-Mutka, Punie 2010). Opracowują m.in. katalogi kompetencji cyfrowych obywateli, kompetencji cyfrowych konsumentów, kompetencji cyfrowych w zakresie przedsiębiorczości. Badania Wspólnego Centrum Badawczego Komisji Europejskiej (European Commission Joint Research Centre - JRC) w obszarze badania kompetencji cyfrowych rozpoczęły się w 2005 r. i koncentrują się na określeniu optymalnego sposobu wykorzystania technologii informacyjno-komunikacyjnych w procesie uczenia, w tym szczególnie nabywania nowych kompetencji i umiejętności. Badania JRC w latach 2016-2017 opierały się na trzech głównych aspektach, tj. umiejętnościach i kompetencjach XXI w., innowacji i modernizacji systemu edukacji i szkolenia oraz rozwoju tzw. otwartej edukacji (Learning and Skills...).

JRC jako umiejętności i kompetencje XXI w. wskazało kreatywność, przedsiębiorczość, umiejętność uczenia się. Raport DIGCOMP, poświęcony opracowaniu tzw. ram rozwoju i zrozumienia kompetencji cyfro- 
wych w Europie, przygotowany przez JRC (Ferrari 2013, s. 4-5) jako główne obszary kompetencji cyfrowych wymienia:

$\rightarrow$ Informacje: identyfikowanie, lokalizowanie, pobieranie, przechowywanie, organizowanie i analizowanie informacji cyfrowych przy równoczesnej ocenie ich przydatności i celu.

$\rightarrow$ Komunikacja: komunikowanie w środowisku cyfrowym, udostępnianie zasobów za pomocą narzędzi online, łączenie się z innymi i współpraca za pomocą narzędzi cyfrowych, interakcja i uczestnictwo w społecznościach i sieciach, świadomość międzykulturowa.

$\rightarrow$ Tworzenie treści: tworzenie i edytowanie nowych treści (od przetwarzania tekstu do obrazów i wideo); integrowanie i ponowne opracowywanie wcześniejszej wiedzy i treści; tworzenie i twórcze wyrażenie, produkty medialne i programowanie; zajmowanie się prawem własności intelektualnej i licencji oraz ich zastosowanie.

$\rightarrow$ Bezpieczeństwo: ochrona osobista, ochrona danych, ochrona tożsamości cyfrowej, środki bezpieczeństwa, bezpieczne i zrównoważone użytkowanie.

$\rightarrow$ Rozwiązywanie problemów: identyfikacja cyfrowych potrzeb i zasobów, podejmowanie świadomych decyzji co do tego, które narzędzia cyfrowe są najbardziej odpowiednie w zależności od celu lub potrzeby, rozwiązywanie problemów pojęciowych za pomocą środków cyfrowych, kreatywne wykorzystywanie technologii, rozwiązywanie problemów technicznych, rozwijanie kompetencji własnych i pomoc w rozwijaniu kompetencji innych.

W zakresie tworzenia treści, gdzie kreatywność odgrywa istotną rolę, raport wskazuje na znaczenie takich umiejętności jak:

$\rightarrow$ Opracowywanie treści, tj. tworzenie treści w różnych formatach, w tym multimedialnych, oraz ich edycja i ulepszanie; także tych, które powstały wcześniej lub zostały stworzone przez innych (w celu twórczego wyrażania się za pomocą cyfrowych mediów i technologii).

$\rightarrow$ Integracja i ponowne opracowanie (w celu zmodyfikowania, udoskonalenia i połączenia istniejących zasobów w celu stworzenia nowej, oryginalnej i odpowiedniej treści i wiedzy).

$\rightarrow$ Prawa autorskie i licencje ( $w$ celu zrozumienia, w jaki sposób prawa autorskie i licencje mają zastosowanie do informacji i treści). 
$\rightarrow$ Programowanie (w celu zastosowania ustawienia, modyfikacji programu, aplikacji programowych oraz zrozumienia zasad programowania).

W badaniach Sue Cranmer (2014, s. 165-177) przedstawiono podobny katalog kluczowych kompetencji cyfrowych. W większości analiz w zakresie kompetencji cyfrowych kreatywność identyfikowana jest jako istotna umiejętność, umożliwiająca przede wszystkim tworzenie treści, a następnie ich przetwarzanie, z wykorzystaniem narzędzi informatycznych i cyfrowych. Kreatywność pozwala na tworzenie produktów, w tym produktów cyfrowych, $z$ wykorzystaniem narzędzi technologicznych, stanowiących w gospodarce cyfrowej główne narzędzia pracy. Nowe technologie, aby mogły zostać efektywnie wykorzystane, wymagają zastosowania procesu twórczego myślenia. W kontekście katalogu kompetencji cyfrowych tworzenie treści należy uznać za jedną z najważniejszych kompetencji cyfrowych, przede wszystkim ze względu na to, że generuje największą wartość dodaną. Kompetencje w obszarze wykorzystywania technologii informacyjno-telekomunikacyjnych wskazywane są jako istotne szczególnie z perspektywy edukacji i zarządzania (Passey, Tatnall 2014, s. 165-177). Narzędzia te muszą stać się podstawą systemu edukacji w zakresie technologii cyfrowych.

\section{Kreatywność jako kluczowa kompetencja ery cyfrowej. Bariery i czynniki rozwoju kreatywności}

Kreatywność można zdefiniować jako umiejętność tworzenia nowych pomysłów. Zależy ona od wielu czynników - przede wszystkim od wiedzy i doświadczenia, stanowiących "pulę" zasobów, które możemy wykorzystać w procesie twórczym, oraz od motywacji i ambicji, pozwalających podjąć trud tworzenia nowych kombinacji na podstawie znanych faktów. Nie bez znaczenia pozostają intuicja i otwartość, a także pewność siebie, które wpływają na ograniczenie wewnętrznej krytyki w procesie generowania nowych pomysłów. Pewne cechy osobowościowe ograniczają kreatywność, a inne, jak gotowość do ryzyka, elastyczność, ją wzmacniają. W gospodarce cyfrowej, a jednocześnie gospodarce obfitości zasobów wiedzy i dostępu do nich, to właśnie umiejętność tworzenia nowych kombinacji z istniejących danych decyduje o przewagach rynkowych. Co więcej, cyfryzacja wpływa też na wzrost znaczenia sektora kreatywnego, na który składają się m.in. reklama, architektura, 
dzieła sztuki, rzemiosło artystyczne, wzornictwo i projektowanie mody, wideo, film, działalność muzyczna i fotografia, działalność artystyczna, ale także działalność w zakresie oprogramowania.

Richard Florida (2002) uważa, że najlepiej rozwijające się ośrodki miejskie to te z najsilniejszą tzw. klasą kreatywną. Według niego istnieją trzy siły działające pozytywnie na miasta, tj. technologia, talent i tolerancja. Miejsca tolerancyjne, otwarte, o różnorodnej strukturze demograficznej i przyjazne przyciągają kreatywne jednostki. Oznacza to, że rozwój takich kompetencji miękkich jak: tolerancja, otwartość, autentyczność, stanowi ważny element rozwoju kreatywności.

Innowacyjność, rozumiana jako proces wdrażania rynkowego nowych pomysłów, nie ma charakteru liniowego. Poszukiwanie nowych, możliwych do wdrożenia pomysłów ma z punktu widzenia przedsiębiorstwa charakter gry zespołowej. Ważną rolę w rozwoju kreatywności odgrywa zatem kultura organizacyjna, m.in. zachęcająca do konstruktywnej krytyki. Ma to umożliwić spojrzenie na dany pomysł z różnych perspektyw. Należy też zauważyć, że zróżnicowane, interdyscyplinarne zespoły są z reguły bardziej efektywne niż zespoły homogeniczne. Kreatywność cechuje się procesowością i etapowością, wymaga współpracy zespołu ludzi, godzenia interesów różnych stron. Kreatywność zaczyna być postrzegana jako kompetencja, którą można i należy zarządzać systemowo. Złożona teoria kreatywności wskazuje bowiem, że kreatywność nie składa się z talentów jednostek, ale zależy od umiejętności zarządzania tym procesem na poziomie zbiorowym, w tym od optymalnego zarządzania relacjami i zasobami wewnątrz określonej grupy czy struktury (Kasza 2014, s. 49). Brak systemowego podejścia do kreatywności i rozwoju systemu sprzyjającego jej rozwojowi sprawia, że w praktyce większość firm nie jest gotowa zmierzyć się z problematyką kreatywności. Dotyczy to głównie indywidualnego pracownika, którego kreatywny potencjał zwykle nie jest w pełni wykorzystany. Większość przełożonych mimo deklaracji nadal bardziej ceni zręcznych wykonawców poleceń, sprawnych, ale niezbyt twórczych rzemieślników (Kasza 2014, s. 48). Podobnie jest w szkołach i na uczelniach wyższych. W odróżnieniu od przedsiębiorstw, jednostki edukacyjne, bez realnych zagrożeń finansowych, mogłyby w dość prosty sposób wprowadzać nowe praktyki i standardy, kształtując nowe pokolenie pracowników potrafiących odnaleźć się w kulturze otwartości ¡ kreatywności. Powyższe wskazuje, że narzędzia rozwoju kreatywności 
powinny być postrzegane szeroko, nie tylko jako techniki kreatywności, ale rozwój umiejętności miękkich i zarządczych w zakresie tworzenia otoczenia sprzyjającego kreatywności.

\section{Cyfrowe narzędzia wsparcia kreatywności}

Narzędzia cyfrowe mogą skutecznie wspomagać rozwój kreatywności i dzięki temu stanowić wartość dodaną w otoczeniu edukacyjnym. Są one dla nauczycieli istotnym wsparciem w procesie rozwoju kreatywności. Narzędzia cyfrowe rozumieć należy jako oparte na zastosowaniu technologii informacyjno-komunikacyjnych. To przede wszystkim oprogramowanie $w$ formie aplikacji, stanowiące jedno $z$ narzędzi do wykorzystania w procesie edukacyjnym, nabywania kompetencji, wykazujące liczne przewagi w stosunku do tradycyjnych metod. Narzędzia te będą spełniać swoją rolę, jeśli umożliwią rozwój innowacyjności, interdyscyplinarnego podejścia i tworzenie własnych kreatywnych rozwiązań.

Narzędzia cyfrowe mogą być także wykorzystywane jako wsparcie dla narzędzi rozwoju kreatywności, spośród których można wymienić mind mapping, TRIZ czy burze mózgów, a także popularną metodę Design thinking. Każda z nich może być wsparta narzędziami cyfrowymi. Badania naukowe sugerują, że korzystające z technologii cyfrowych techniki mapowania pojęć zwiększają szybkość uczenia się (Riley, Ahlberg 2004). Narzędzia wsparcia procesów kreatywnych możemy podzielić na: narzędzia dywergencji (divergence tools), przeznaczone do generowania maksymalnej liczby niepokrywających się ze sobą pomysłów, oraz narzędzia konwergencji (convergence tools), które służą analizie, filtrowaniu i łączeniu pomysłów/idei w celu wyboru najlepszych. Różne grupy narzędzi wykorzystywane są w różnych fazach procesu innowacyjnego i mają różne cele.

Andrew Field (2015), ekspert Cambridge Education International Centre [Centrum Oceny Edukacji Międzynarodowej] Uniwersytetu w Cambridge, wymienia narzędzia cyfrowe, które mogą skutecznie pobudzać kreatywność w procesie edukacji. Są to:

$\rightarrow$ Socrative, socrative.com

Socrative to prosta w obsłudze aplikacja do tworzenia quizów, ankiet i opinii. Można jej użyć do przeprowadzenia quizu podczas lekcji, uczniowie rozwiązują zadania w czasie rzeczywistym na swoich urządzeniach mobilnych. Aplikacja umożliwia automatyczną ocenę wykonanych zadań i śledzenie postępów 
uczniów. Uczniowie mogą tworzyć własne treści (quizy, zadania) i udostępniać je wybranej grupie osób. Mogą też zbierać opinie na temat swoich prac, dzielić się swoimi propozycjami z resztą klasy. Narzędzie ma na celu przede wszystkim umożliwienie skutecznego procesu współpracy i wymiany pomysłów.

$\rightarrow$ Classtools.net, classtools.net Classtools.net to kolekcja narzędzi online pobudzających kreatywność, pozwalających każdemu tworzyć własne opracowania edukacyjne w szybki i intuicyjny sposób, $z$ wykorzystaniem dostępnych, łatwo modyfikowanych szablonów online. Aplikacja udostępnia ponad 40 darmowych narzędzi i dodatków. Jednym z najlepszych przykładów jest Fakebook, za pomocą którego uczniowie mogą zbudować własną stronę podobną do Facebooka dla postaci historycznej lub tematu, którego się uczą. Mogą np. tworzyć profile śledzące wpływ ważnego wydarzenia, refleksje na temat debaty politycznej lub strumień kreatywności, który doprowadził do powstania muzycznego arcydzieła.

$\rightarrow$ Kahoot, kahoot.it

Kahoot pozwala każdemu tworzyć własne quizy do przeprowadzania konkursów na forum klasy. Członkowie grupy, do której skierowany jest quiz, odpowiadają za pomocą dowolnego urządzenia $z$ dostępem do sieci internetowej. Jedną z funkcji aplikacji jest wyświetlanie wyników quizów w czasie rzeczywistym. Uczniowie mają też możliwość tworzenia własnych konkursów, projektowania własnego systemu oceny i docelowo przejmują odpowiedzialność za proces uczenia.

\section{Podsumowanie}

W katalogu kompetencji cyfrowych szczególnego znaczenia nabiera kreatywność, mająca zastosowanie we wszystkich sferach życia i stanowiąca główny napęd gospodarki kreatywnej, opartej na innowacjach. Gospodarka cyfrowa daje szerokie instrumentarium, by przyswojenie nowych kompetencji było jak najbardziej efektywne. Adaptacja narzędzi cyfrowych już na etapie edukacji pozwoli na zwiększenie wydajności i satysfakcji z wykonywanej pracy przyszłych pracowników. Nowe narzędzia cyfrowe, tj. aplikacje wspomagające edukację i tworzenie treści, pojawiają się w bardzo szybkim tempie. Popyt na tego typu rozwiązania 
wzrasta, gdyż potwierdza się ich skuteczność w procesach edukacyjnych. Pozwalają one m.in. na szybką ewaluację podejmowanych działań, na śledzenie i szybką analizę postępów. Nie wymagają czasochłonnej archiwizacji działań. Pozwalają uczącym się i nauczającym przeznaczać większą ilość czasu na działania niestandardowe, a więc twórcze i kreatywne.

Nowa gospodarka to zatem wyzwania nie tylko dla rynku pracy, ale przede wszystkim dla systemu edukacji. Zmieniające się dynamicznie otoczenie wymaga nowych kompetencji, a więc dostosowania programów edukacyjnych do nowych realiów technologicznych i społeczno-gospodarczych Wyposażenie uczniów w kompetencje, które pozwolą im jak najlepiej odnaleźć się w nowym otoczeniu, powinno stanowić wyznacznik dla opracowywanych programów kształcenia. Kluczowym wyzwaniem polityki naukowej i gospodarczej jest zapewnienie, by podaż i popyt na nowe umiejętności i kompetencje były jak najbardziej dopasowane. Według Komisji Europejskiej (Learning and Skills...) to nauka odpowiednich umiejętności jest kluczowym czynnikiem wpływającym na rozwój społeczeństwa i gospodarki. To ona ma zagwarantować obywatelom możliwość znalezienia zatrudnienia i aktywne uczestnictwo w życiu społecznym. 



\title{
Kreatywność w rozwiązywaniu problemów biznesowych
}

\author{
Sergiusz Sawin
}

W rozdziale przedstawiono sposób, w jaki duże organizacje i ich otoczenie zewnętrzne podchodzą do kwestii kreatywności oraz budują kompetencje w zakresie kreatywnego rozwiązywania problemów. Opisano typowe wyzwania stojące przed podmiotami biznesowymi chcącymi przekształcić się w prawdziwie kreatywne organizacje oraz narzędzia wykorzystywane na każdym etapie procesu, przez który przechodzi firma. Ponadto zaprezentowano studia przypadków opisujące faktyczne projekty realizowane przez wybrane duże organizacje noszące się z zamiarem wprowadzenia nowych kreatywnych rozwiązań. W ostatniej części wymieniono kilka technik wspierających kreatywne rozwiązywanie problemów.

\section{Słowa kluczowe:}

kreatywne rozwiązywanie problemów

innowacyjność

podważanie założeń

budowanie kreatywnych organizacji

kampanie innowacyjne

wymiana dobrych praktyk 


\section{Creativity in solving business problems}

Sergiusz Sawin

The article explains how creativity in big organisations is perceived by both internal and external stakeholders and how they build their skills and capabilities in the area of creative problem solving. The typical challenges faced by different business entities willing to turn into truly creative organisations are listed together with the tools used at different stages of their development. Author provides a couple of case studies of real business projects that were executed by big organisations willing to implement new creative solutions. Last part is dedicated to presentation of selected tools supporting creative problem solving.

\section{_ Keywords: \\ creative problem solving \\ innovativeness \\ challenging assumptions \\ building creative organisations \\ innovation campaigns \\ sharing good practices}




\section{Kreatywność w biznesie - faktyczne działanie czy myślenie życzeniowe}

Jeżeliby spytać przedstawicieli dojrzałych organizacji o ustabilizowanych strukturach i pozycji rynkowej, czy kreatywność w biznesie jest istotnym elementem budowania pozycji rynkowej, z pewnością większość z nich odpowiedziałaby twierdząco. Firmy od lat inwestują w szkolenia kreatywności, programy proinnowacyjne, prowadzą spotkania typu "burze mózgów", szkolą wewnętrznych trenerów i wskazują w opisach stanowisk kreatywność jako pożądaną cechę każdego pracownika. W 2010 r. IBM przeprowadził bardzo szerokie badanie obejmujące swym zasięgiem ponad 1500 przedstawicieli najwyższego szczebla menedżerskiego. Podczas badania pytano o to, jakie cechy przywódcze będą najistotniejsze w ciągu najbliższych pięciu lat. Ponad $60 \%$ badanych osób wskazało kreatywność jako najważniejszą cechę przyszłego lidera (IBM 2010).

$Z$ drugiej strony, na podstawie mojej wieloletniej praktyki korporacyjnej, a także doradczej w projektach innowacyjnych dla dużych korporacji, mogę stwierdzić, że w bardzo niewielu organizacjach pozytywny stosunek do działań wspierających kreatywność przekłada się na konkretne zmiany w sposobie myślenia kierownictwa firmy, tak aby zmieniać organizację w sposób systemowy i dogłębny.

Z tezą tą zgadza się także większość konsumentów i klientów dużych międzynarodowych firm. Według badania przeprowadzonego przez magazyn "TRUE" w 2016 r. prawie 72\% respondentów stwierdziło, że większości korporacji nie można uznać za kreatywne firmy (Corporations, Creativity and Consumers 2016).

Dzieje się tak z kliku powodów. Po pierwsze, celem dużych organizacji, a w szczególności korporacji, jest długofalowy stabilny wzrost zysku. Aby ów cel osiągnąć, zarządy i menedżerowie wyższego szczebla skupiają się przede wszystkim na prowadzeniu działań, które zminimalizują potencjalne zaburzenia tego wzrostu w krótkim i średnim terminie. Każde niesprawdzone, niestandardowe działanie, a do takich niewątpliwie należą działania kreatywne, stanowi więc potencjalne ryzyko destabilizacji.

Drugim istotnym czynnikiem, który może blokować kreatywność organizacji, jest kultura biznesowa czy ogół przyjętych wzorców zachowań i postaw pracowników w miejscu pracy. Na kulturę biznesową składają się także takie elementy jak: otwartość na zmiany, zdolność 
do podejmowania ryzyka, sposób budowania relacji w ramach struktury organizacyjnej, zakres autonomii w podejmowaniu decyzji, przywiązanie do sprawdzonych sposobów postępowania. Wszystkie wymienione obszary kultury mogą mieć negatywny wpływ na promowanie niestandardowych postaw, ponieważ z założenia oczekuje się, że nowo przyjęty pracownik dostosuje się do utartych schematów postępowania, a nie odwrotnie. Jedynie w przypadku zmian na najwyższych stanowiskach w firmie, czyli prezesa i zarządu, możemy upatrywać szansy na głębsze zmiany kultury organizacyjnej.

Po trzecie, sam sposób rekrutacji pracowników zachęca do utrzymania status quo. Na każde stanowisko $w$ firmie szuka się pracowników o określonym, jasno zdefiniowanym profilu zgodnym z oczekiwaniami. Podczas rekrutacji promuje się osoby z dużym doświadczeniem w branży, a więc takie, które mogą przynieść ze sobą do firmy wiedzę o dobrych praktykach wyniesionych z podobnych organizacji. Nie spotkałem się z sytuacją, żeby na stanowisko np. dyrektora marketingu szukano osoby, która nigdy w marketingu nie pracowała, a przykładowo jest wziętym artystą. W ten sposób utrwalamy aktualne schematy postępowania, co prawda, wzbogacając firmę o trochę doświadczeń branżowych, ale cały czas poruszając się w bezpiecznym środowisku.

Po czwarte wreszcie, sama domena czystej kreatywności jest w dużych organizacjach zarezerwowana dla partnerów i dostawców firmy, w tym przede wszystkim agencji kreatywnych, agencji eventowych, domów mediowych, zewnętrznych trenerów i konsultantów. To od pracowników tych podmiotów oczekuje się kreatywności, niestandardowego spojrzenia, świeżych pomysłów, łamania schematów i inspiracji, która i tak zostanie potem zamknięta $w$ bezpieczne ramy organizacji. W rezultacie pracownik firmy nie musi być kreatywny, ponieważ ma od tego ludzi, którym za to płaci.

Czy zatem do rozwiązywania problemów biznesowych potrzebna jest kreatywność? Czy nie wystarczy sięgnąć do sprawdzonych wzorów z własnej lub pokrewnych branż i, nie podejmując specjalnie ryzyka, zaadaptować je do bieżącego kontekstu?

Dawniej być może to wystarczało. Dziś, w czasach rewolucji cyfrowej, opieranie się wyłącznie na wzorcach z przeszłości może być śmiertelną pułapką, choć w różnych branżach sytuacja może wyglądać zupełnie inaczej. 


\title{
Gotowość organizacji do kreatywnego rozwiazywania problemów
}

\author{
Organizacje przechodzą kilka stadiów rozwoju. Wspomniana wcześniej \\ zdolność absorpcji dobrych praktyk z wewnątrz lub zewnątrz organizacji \\ jest pierwszym krokiem w stronę budowania prawdziwie kreatywnej or- \\ ganizacji zdolnej do skutecznego wdrażania niestandardowych pomysłów. \\ Jest to jednak dopiero początek długiej drogi, którą duża firma musi przejść.
}

\section{STUDIUM PRZYPADKU: ZBIERANIE DOBRYCH PRAKTYK}

Zarząd dużej sieci restauracji działającej na zasadach franczyzy podczas corocznego zjazdu franczyzobiorców postanowił zorganizować warsztaty dobrych praktyk, podczas których kilkanaście zespołów składających się głównie z właścicieli poszczególnych restauracji zostało poproszonych o opisanie dobrych praktyk przynoszących wymierne korzyści w ich placówkach. Zespoły podzielono według kilku głównych obszarów tematycznych typu: zarządzanie kosztami, motywowanie pracowników, obsługa klienta itp.

Efektem warsztatów miało być stworzenie tzw. księgi dobrych praktyk, czyli podręcznika franczyzobiorcy, z opisami wszystkich działań usprawniających pracę restauracji. W ramach warsztatów przeprowadzono także głosowanie i wybierano najlepsze "dobre praktyki”, a ich autorzy otrzymywali nagrody specjalne ufundowane przez zarząd firmy. Główne kryteria oceny to: prostota wdrożenia i wymierny efekt. Jedną z dobrych praktyk wyróżnionych tego dnia w kategorii: „zarządzanie kosztami" była praktyka codziennego odkurzania wentylatora po zamknięciu restauracji. Jak się okazało, pył z mąki unoszący się podczas wyrabiania ciasta do pizzy zatykał wentylator tak skutecznie, że koszt energii pobranej do jego pracy znacznie wzrastał. Odkurzanie wentylatora pozwoliło każdego dnia zaoszczędzić kilkanaście procent na kosztach energii elektrycznej.

Tabela 1. Ewolucja kreatywnych organizacji
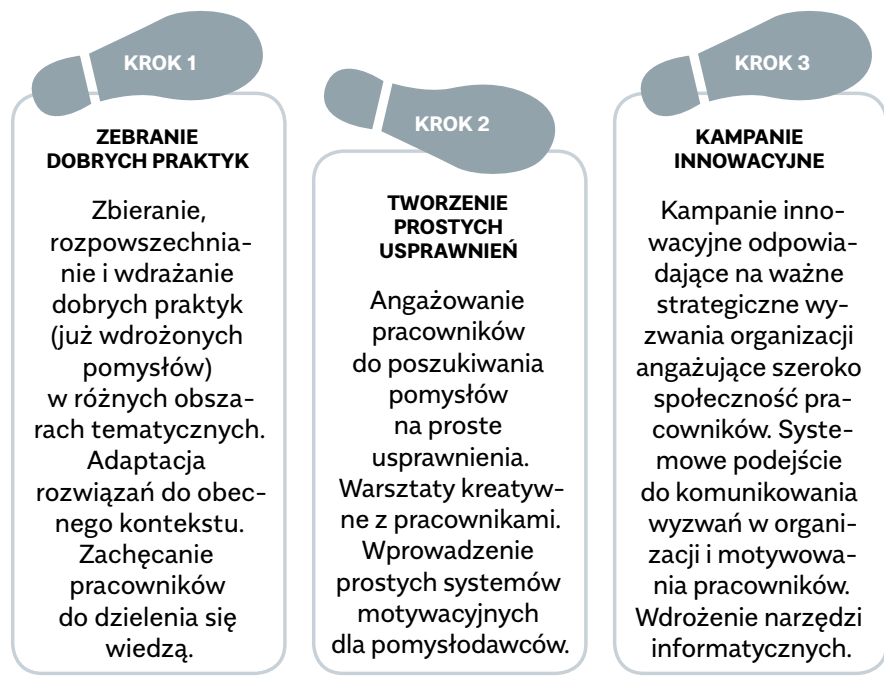

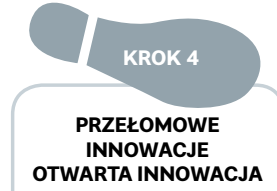

Skoordynowane prace zespołów roboczych, których celem jest wypracowanie przełomowych rozwiązań.

Zaangażowanie otoczenia zewnętrznego (ekspertów, klientów, dostawców) we wspólne tworzenie innowacji.

Źródło: opracowanie własne. 
Pierwsze dwa etapy mają na celu przede wszystkim budowanie otwartości w organizacji, promowanie dzielenia się wiedzą i swoimi doświadczeniami. Problemy biznesowe mają tutaj znaczenie drugorzędne i mogą raczej stanowić pewnego rodzaju inspirację. Nie oczekuje się od pracowników przyniesienia kreatywnego przełomowego rozwiązania, a raczej czegoś, co jest bezpieczne, sprawdzone i co łatwo wdrożyć.

Dopiero dzięki pozytywnym doświadczeniom i lekcjom wyciągniętym z działań podjętych na tych dwóch pierwszych etapach większość organizacji zaczyna rozważać wdrożenie systemowego podejścia do rozwiązywania problemów organizacji. Najczęściej wybieraną ścieżką są kampanie innowacyjne, a więc zbudowanie usystematyzowanego procesu zbierania pomysłów pracowników, odpowiadających na określone wyzwania biznesowe. Kampanie mogą obejmować całą społeczność pracowników firmy lub być ograniczone do ściśle określonej grupy, np. pracowników placówek banku, przedstawicieli handlowych lub działu obsługi klienta. Aby kampanie były skuteczne, muszą opierać się na kilku podstawowych założeniach.

\section{STUDIUM PRZYPADKU: KAMPANIE INNOWACYJNE}

W 2005 r. Telekomunikacja Polska S.A. wdrożyła program „Innovate TP!”. Jednym z jego obszarów było budowanie klimatu dla innowacyjności i włączanie pracowników w kreatywne rozwiązywanie problemów. Zdecydowano się przetestować podejście kampanijne. Grupa menedżerów wyższego szczebla została poproszona o przysłanie propozycji wyzwań istotnych dla organizacji, które mogły posłużyć za tematy pierwszych kampanii. Zapoznając się z zebranymi propozycjami, komitet sterujący zdecydował się na wybór następującego tematu: „W jaki sposób zmniejszyć wskaźnik churnu i skłonić klientów do pozostania z nami". Churn to wskaźnik odejścia klientów, a więc bardzo istotny czynnik sukcesu działania każdej organizacji. W przypadku Telekomunikacji Polskiej w tym okresie, gdy wielu klientów rezygnowało z telefonów stacjonarnych, wysoki wskaźnik churnu był istotnym problemem.

Kampania trwała trzy tygodnie, zebrano kilkadziesiąt pomysłów oraz kilkaset komentarzy i uzupełnień do nich. Wiele z nich było naprawdę bardzo kreatywnych. Zwyciężył pomysł, który dzisiaj nikogo nie dziwi, ale w tamtym czasie był w jakimś stopniu przełomowy. Zdaniem pomysłodawcy najlepszym sposobem na redukcję churnu jest kontakt z klientem mniej więcej 1-2 miesiące przed upływem terminu zakończenia umowy w celu jej odnowienia. Pomysł został oczywiście w szybkim czasie wdrożony, co przełożyło się na znaczną redukcję churnu i w krótkim czasie stało się standardem nie tylko w branży telekomunikacyjnej.

Założenia kampanii innowacyjnych:

$\rightarrow$ Każda kampania ma jasno zdefiniowane wyzwanie biznesowe posiadające właściciela, zwykle osobę z zarządu firmy lub menedżerów wyższego szczebla. 
$\rightarrow$ Pomysły należy zgłaszać przez odpowiednio przygotowany formularz dopasowany każdorazowo do wyzwania i oczekiwań ekspertów i sponsora. Bardziej złożony formularz ogranicza liczbę pomysłów, ale powoduje, że zgłaszane pomysły są lepiej dopracowane.

$\rightarrow$ Kampania trwa przez ściśle określony czas, po którym wyznaczone grono ekspertów ocenia zgłoszone pomysły.

$\rightarrow$ Zwykle pomysły zgłaszane są za pomocą narzędzia informatycznego, które umożliwia nie tylko wpisywanie pomysłów, ale także ich komentowanie i sprawną ocenę przez ekspertów, a także monitorowanie aktywności pracowników.

$\rightarrow$ Dla każdej kampanii tworzy się system motywacyjny. W bardziej zaawansowanych kampaniach pracownicy otrzymują nagrody nie tylko za najlepsze pomysły, ale także za aktywność w kampanii i wkład w rozwój pomysłów zgłoszonych przez innych.

Firmy mające już za sobą kilka lub kilkanaście kampanii innowacyjnych stopniowo otwierają się na współpracę z otoczeniem zewnętrznym. Do kampanii zapraszani są zaufani partnerzy firmy (dostawcy, odbiorcy, kluczowi klienci). Ich wkładem są często pomysły niestandardowe, czerpiące z doświadczeń ze współpracy z innymi partnerami. Przy specyficznych wyzwaniach pomóc może także konkretna wiedza branżowa. Może się także okazać, że podmioty partnerskie mają w swoim harmonogramie projektów badawczo-rozwojowych rozwiązania częściowo lub w pełni odpowiadające na wyzwanie zgłoszone podczas kampanii. Praca nad problemem klienta może więc skutkować przyspieszeniem działań w określonym obszarze, aby szybciej odpowiedzieć na zgłoszoną potrzebę. Praca z klientami zewnętrznymi może odbywać się na zasadach podobnych do tych w kampaniach innowacyjnych lub też $w$ formie warsztatów kreatywnych prowadzonych przez firmę lub wynajętych trenerów zewnętrznych.

Warsztaty takie często stanowią początek szerszej współpracy w formule tzw. Rady Klienta (Customer Advisory Boards), polegającej na organizowaniu cyklu regularnych spotkań poświęconych różnym tematom dotyczącym oferty i rozwiązywania bieżących problemów pojawiających się w toku współpracy.

Na tym etapie dojrzałości organizacji zwykle jeszcze nie ma jednolitej strategii otwierania się na otoczenie zewnętrzne. To, jaki charakter 
przybierze współpraca z partnerami biznesowymi, a w szczególności z bardzo popularnymi ostatnio start-upami, zależy w dużej mierze od tego, jaka część organizacji tę współpracę inicjuje i jakie cele chce przy tym zrealizować.

Tabela 2. Główne działy w organizacji i ich cele oraz motywacje

\begin{tabular}{|c|c|c|c|c|}
\hline DZIAK HR & MARKETING \& PR & $\begin{array}{l}\text { LOGISTYKA, } \\
\text { SPRZEDAZ̈, } \\
\text { MARKETING, } \\
\text { PRODUKCJA }\end{array}$ & $\begin{array}{l}\text { DZIAL STRATEGII, } \\
\text { INNOWACJI, CVC } \\
\text { (CORPORATE } \\
\text { VENTURE CAPITAL) }\end{array}$ & DZIAk R\&D \\
\hline $\begin{array}{l}\text { budowanie kul- } \\
\text { tury wspierającej } \\
\text { transformację } \\
\text { cyfrową biznesu, } \\
\text { budowanie start- } \\
\text {-up mindset, za- } \\
\text { rządzanie zmianą } \\
\text { w organizacji }\end{array}$ & $\begin{array}{l}\text { wzmocnienie } \\
\text { wizerunku firmy } \\
\text { jako firmy kre- } \\
\text { atywnej, otwartej } \\
\text { na start-upy, } \\
\text { angażującej się } \\
\text { we współpracę } \\
\text { z ekosystemem } \\
\text { start-upowym, } \\
\text { budowanie } \\
\text { wizerunku wśród } \\
\text { potencjalnych } \\
\text { przyszłych pra- } \\
\text { cowników firmy }\end{array}$ & $\begin{array}{l}\text { poszukiwanie } \\
\text { rozwiązań bieżą- } \\
\text { cych problemów }\end{array}$ & $\begin{array}{l}\text { poszukiwanie } \\
\text { pomysłów na } \\
\text { nowe produkty } \\
\text { i usługi poza } \\
\text { podstawową } \\
\text { działalnością }\end{array}$ & $\begin{array}{l}\text { poszukiwanie } \\
\text { technologii we } \\
\text { wczesnej fazie } \\
\text { rozwoju w celu } \\
\text { zwiększenia } \\
\text { efektywno- } \\
\text { ści produkcji, } \\
\text { zmniejszenia } \\
\text { kosztów, wy- } \\
\text { eliminowania } \\
\text { niepożądanych } \\
\text { skutków, rozwój } \\
\text { oferty }\end{array}$ \\
\hline
\end{tabular}

Źródło: Sawin 2018.

\section{STUDIUM PRZYPADKU: KREATYWNE WARSZTATY Z PARTNERAMI BIZNESOWYMI}

W 2013 r. firma Żywiec Zdrój pracowała nad koncepcją nowego produktu przeznaczonego dla młodzieży. Do tej pory większość podobnych projektów realizowano w całości wewnętrznie. W skład zespołu projektowego wchodzili pracownicy działów R\&D, marketingu i strategii. Klasyczne podejście polegało na przygotowaniu briefu przez dział strategii, w którym wstępnie określono cele biznesowe dla nowego produktu. Następnie dział marketingu na podstawie szerokich badań rynkowych definiował rodzaj produktu oraz segment, do którego ma być kierowany. Tak przygotowane zlecenie trafiało do działu R\&D, gdzie przeprowadzano analizy techniczne, kontaktowano się z producentami opakowań i środków spożywczych i przygotowywano koncepcję produktu do dalszych badań przez marketing. Tym razem postanowiono zmienić podejście i od początku zaangażować potencjalnych dostawców produktu w proces wymyślania koncepcji. Opracowano koncepcję intensywnego jednodniowego warsztatu kreatywnego, w którym mieli uczestniczyć pracownicy kluczowych działów firmy oraz przedstawiciele pięciu niekonkurujących ze sobą dostawców różnych komponentów do produkcji końcowego produktu, m.in. dostawca opakowań PET, producenci zakrętek i etykiet. Każdego z nich poproszono o przyjście na warsztat z koncepcjami innowacyjnych rozwiązań z ich obszaru, odpowiadających na wyzwania, z którymi mierzył się klient. Dzięki temu podczas warsztatu mieszane zespoły pracowników Żywiec Zdrój i kilku dostawców, pracując nad wstępnymi koncepcjami cząstkowymi, mogły w ciągu jednego dnia przygotować spójne pomysły rozwiązań odpowiadających na strategiczną potrzebę firmy i zawierających wszystkie niezbędne składowe docelowego produktu. 
Organizacje, które mają już za sobą wiele doświadczeń związanych z pobudzaniem zarówno wewnętrznej, jak i zewnętrznej kreatywności w celu rozwiązywania bieżących problemów biznesowych, zaczynają wdrażać narzędzia i procesy wspierające poszukiwanie nowych modeli biznesowych i produktów wykraczających poza standardowo oferowane kategorie produktowe. Tego typu działania wymagają przebudowy organizacji, ponieważ radykalnych innowacji nie da się realizować wyłącznie za pomocą dotychczasowych metod i środków. Nie sprawdza się tradycyjne podejście typu waterfall oraz stosowany standardowo liniowy proces stage-gate, w którym zakłada się, że kolejne etapy tworzenia rozwiązania następują w ściśle określonej kolejności na podstawie założeń projektu zdefiniowanych już na samym początku. Są to podejścia z natury przygotowane do tworzenia innowacji inkrementalnych opartych na weryfikacji sprawdzonych wcześniej założeń, bazujące na dotychczasowych kompetencjach i udokumentowanej wiedzy rynkowej. Przygotowanie do tworzenia radykalnych innowacji wymaga więc powołania osobnych jednostek biznesowych o odrębnie zdefiniowanych celach, nowych kompetencjach i wiedzy na temat metod i narzędzi stosowanych przez młode spółki technologiczne i start-upy. Wiele dojrzałych przedsiębiorstw przekonało się boleśnie, jak trudno stworzyć radykalnie nowy biznes, bazując wyłącznie na dotychczasowym zespole z wszystkimi jego ograniczeniami i założeniami, które z czasem stają się dogmatami skutecznie paraliżującymi jakiekolwiek wysiłki zmierzające do ich podważenia. A przecież gdyby prześledzić historie sukcesów tzw. unicornów, a więc firm, które w bardzo krótkim czasie podbiły światowy rynek, osiągając ogromną wartość rynkową, bardzo łatwo można dojść do wniosku, że ich podstawową motywacją było podważanie założeń przyjętych wcześniej w branży, którą postanowili podbić. 
STUDIUM PRZYPADKU: PODWAŻANIE ZAKOŻEŃ W BRANŻY OŚWIETLENIOWEJ

Jeden z głównych producentów oświetlenia od kilku lat planował odświeżenie swojej oferty oświetlenia sufitowego dla biur. W przeszłości firma słynęła z innowacyjnych rozwiązań, wiele razy wprowadzając jako pierwsza na rynek nowe produkty, m.in. energooszczędne neony, nowe barwy i niestandardowe obudowy. W ostatnim czasie konkurencja się zaostrzyła i mimo że standardowe linie produktowe sprzedawały się bardzo dobrze, zarząd miał poczucie, że brakuje im świeżych pomysłów, które na nowo zdefiniowałyby ich pozycję lidera w branży. Organizowano warsztaty kreatywne, wprowadzono narzędzia do zarządzania pomysłami, opracowano system motywacyjny dla innowatorów, ale wciąż brakowało naprawdę kreatywnych pomysłów. W końcu zdecydowano się zatrudnić firmę zewnętrzną, która mogłaby spojrzeć z dystansem na ofertę firmy i ocenić jej działalność z nowej perspektywy.

Z pomocą zewnętrznych moderatorów zdecydowano się kolejny raz przeprowadzić warsztaty kreatywne, ale tym razem ich formuła była odmienna. Trenerzy poprosili zebrany multidyscyplinarny zespół o wypisanie wszystkich głównych założeń dla obecnych produktów. Chodziło o najbardziej podstawowe założenia, np. takie, że lampa ma świecić. Wkrótce stworzono listę około dwudziestu założeń, w tym takie jak: oświetlenie sufitowe świeci tak samo przez cały dzień, oświetlenie sufitowe znajduje się zawsze w tym samym miejscu, jedyną funkcją lamp biurowych jest oświetlenie miejsca pracy oraz lampa sufitowa, kiedy się zepsuje, przestaje świecić. Następnie poproszono kilka zespołów o wybór założeń, które można byłoby podważyć i na podstawie zmienionych założeń stworzyć kreatywne koncepcje nowych rozwiązań. Okazało się, że dopiero przy zastosowaniu tak niestandardowych metod, zaczęły pojawiać się prawdziwie przełomowe pomysły, m.in. oświetlenie podążające za człowiekiem, lampy zmieniające natężenie oświetlenia w zależności od pory dnia i roku, jarzeniówki informujące, że za kilka dni przestaną świecić.

\section{Znajdź swoje techniki kreatywne}

Niezależnie od tego, na którym etapie znajduje się organizacja i jak wiele ma za sobą doświadczeń w stymulowaniu kreatywności, nieprawdą jest stwierdzenie, że istnieje jedna sprawdzona technika, która pomogłaby rozwiązać każdy problem. Najlepiej próbować wielu i nie zrażać się, gdy nie przynoszą one pożądanych rezultatów. Może się zdarzyć, że w danych okolicznościach i określonym składzie osobowym grupa nie jest w stanie znaleźć żadnego trafionego pomysłu. Nie powinno to być powodem do rozpaczy, ponieważ w pracy kreatywnej nigdy nie da się zagwarantować sukcesu. Z drugiej strony nawet najbardziej fantastyczne pomysły mogą być niemożliwe do zrealizowania. Brytyjska firma WhatIf!, odpowiednik amerykańskiego Ideo, proponuje kilka narzędzi, które sprawdzają się w codziennym rozwiązywaniu problemów biznesowych swoich klientów. Zachęca do ich stosowania w każdej sytuacji, w której brakuje oczywistej odpowiedzi na powstały problem lub odpowiedź ta wydaje się niewystarczająca. Są to tak zwane 4-R (WhatIF! 2002): 
Re-expression - zdefiniuj problem, przed którym stoisz, w sposób inny niż do tej pory (np. słowami kogoś, kto nie jest powiązany z twoją organizacją, odbiorcy, użytkownika końcowego), użyj alternatywnych słów, których nie używasz na co dzień, lub innych zmysłów.

Related worlds - załóż, że z danym problemem ktoś już się kiedyś mierzył, być może w innych branżach i kontekstach, spójrz na biznesy bardzo odmienne od twojego i zastanów się, jak ich przedstawiciele do tego problemu podeszli w przeszłości lub jak mogliby podejść w przyszłości. Znajdź eksperta spoza firmy i otoczenia konkurencyjnego, który mógłby coś wnieść w zrozumienie problemu i znalezienie rozwiązania, i zapytaj go, jakie są jego pomysły.

Revolution - zmień reguły gry i sprowokuj zespół do myślenia. Podważ obecne założenia i zasady, świadomie odwróć reguły i zastanów się, jakie pomysły można byłoby stworzyć, gdyby obowiązywały zupełnie inne zasady (zamiast moczyć, wysusz, substancję stałą zmień w ciekłą, miłą obsługę zmień w stanowczą i asertywną itp.).

Random links - kreatywność powstaje w efekcie zupełnie niestandardowych połączeń różnych skojarzeń i elementów. To dlatego nasze sny wydają się nam tak kreatywne. Daj sobie czas na znalezienie zupełnie dziwacznych połączeń z losowo wybranych słów i zobacz, dokąd cię to zaprowadzi.

\section{Podsumowanie}

Mimo że kreatywny pomysł często rodzi się z przypadku, organizacja, która chce być trwale kreatywna, nie powinna niczego zostawiać przypadkowi. Aby skutecznie rozwiązywać problemy biznesowe, firma musi, po pierwsze, mieć głębokie przekonanie, że w kreatywność warto inwestować w sposób systemowy: budując odpowiednie struktury i procesy, ale także inwestując w odpowiednich ludzi i narzędzia wspierające. Po drugie, zarząd firmy powinien uświadomić sobie, że bycie kreatywnym liderem to długi proces składający się z kilku etapów, począwszy od zbierania dobrych praktyk i wdrażania drobnych usprawnień, aż po złożone projekty tworzenia nowych modeli biznesowych. Kreatywne organizacje są tworzone przez kreatywnych, zmotywowanych ludzi i dlatego tak ważna jest zmiana kultury organizacyjnej, której nie da się przeprowadzić $z$ dnia na dzień. 



\section{Zapotrzebowanie na kompetencje w przemysłach kreatywnych}

Bogumiła Powichrowska

Przemysł kreatywny współcześnie jest definiowany bardzo szeroko. Właściwie nie ma branży, w której kreatywność nie jest potrzebna. Celem rozdziału jest próba określenia kompetencji, głównie miękkich, niezbędnych w przemysłach kreatywnych obecnie i w przyszłości. Rozpoczyna się od zdefiniowania, czym jest przemysł kreatywny, oraz określenia jego potencjału. Następnie przedstawiono nowy model kompetencji wykorzystywany także w branżach opartych na kreatywności. Rozdział kończy się koncepcją sektorowych rad ds. kompetencji, które w opinii autorki pozwalają na bieżąco diagnozować zapotrzebowanie, a rekomendacje przekładać na rzeczywistą ofertę edukacyjną. 


\title{
The demand for competences in creative industries
}

\author{
Bogumiła Powichrowska
}

The creative industry is nowadays defined very broadly. Beyond doubt, there is no industry where creativity is not needed. The aim of the article is to try to define the competencies, mainly the soft ones, necessary in the creative industries now and in the future. The author started by defining what the creative industry is and determining its potential. Then she discussed a new model of competence used also in industries based on creativity. The article ends with a concept of sector competence councils, which in the opinion of the author, allows diagnosing the demand on an ongoing basis and translating recommendations into a real educational offer. The article is of an informative character.

\section{Keywords:}

creative industry

creative sector

competencies

concept of sector competence councils 


\section{Wprowadzenie}

Przemysł kreatywny jest trudny do zdefiniowania. Nazwy tej zwyczajowo używa się na określenie podmiotów świadczących usługi kultury. Jest to podejście bardzo wąskie. Współcześnie łatwiej zdefiniować sektory, w których kreatywność nie jest wykorzystywana. Jeszcze trudniej jest więc oszacować zapotrzebowanie na kompetencje w przemysłach kreatywnych. Wszystko to ze względu na zmienność, nieprzewidywalność, złożoność świata, w którym żyjemy.

Celem rozdziału jest próba określenia kompetencji (głównie miękkich) niezbędnych w przemysłach kreatywnych obecnie i w przyszłości. Zdefiniowano w nim przemysł kreatywny oraz określono jego potencjał. Następnie omówiono nowy model kompetencji wykorzystywany także w branżach bazujących na kreatywności. Przedstawiono także koncepcję sektorowych rad ds. kompetencji, która pozwala na bieżąco diagnozować zapotrzebowanie, a rekomendacje przekładać na rzeczywistą ofertę edukacyjną.

\section{Potencjal przemysłu kreatywnego}

Główny Urząd Statystyczny (GUS) odnotował, że „wraz z postępem technologicznym i zmianą stylu życia, konieczna stała się rewizja dotychczasowych założeń o funkcjonowaniu gospodarki. Jej transformacja od industrialnej do gospodarki opartej na usługach sprawia, że kluczowymi dla rozwoju stają się kapitał ludzki, społeczny i kulturowy, unikatowość, oryginalność, innowacyjność, autentyczność. Słowem kluczem jest «kreatywność», a potencjałem rozwojowym kreatywne zasoby danego miejsca" (Przemysły kultury... 2018). Zauważono także, że co prawda "kreatywność nie jest niczym nowym, nowym pojęciem nie jest też gospodarka, ale to, co jest nowe, to natura i zakres powiązań pomiędzy tymi zjawiskami i to, w jaki sposób łączą się one, by tworzyć niezwykłą wartość i dobrobyt" (Howkins 2001). W rozwijającym się aktualnie modelu kreatywnej gospodarki centralną rolę odgrywa przemysł kultury i kreatywny.

W 2001 r. rząd brytyjski w dokumencie przygotowanym przez Departament for Culture, Media and Sport uznał, że do przemysłu kreatywnego można zaliczyć "te branże, które mają swoje źródła w indywidualnej kreatywności, umiejętności i talencie, a także mają potencjał do tworzenia bogactwa i miejsc pracy poprzez tworzenie i wykorzystywanie własności intelektualnej" (Creative Industries Mapping... 2001). 
Definicja ta ewoluowała. W raporcie z 2016 r. napisano, że "kreatywna gospodarka obejmuje wkład tych, którzy wykonują zawody kreatywne poza branżami kreatywnymi, a także tych z przemysłu kreatywnego. Przemysł kreatywny to podzbiór kreatywnej gospodarki, który obejmuje branże kreatywne same w sobie" (Creative Industries Economic... 2016). Tak szeroka definicja dotyczy wielu branż współczesnej gospodarki. Można by się nawet pokusić o stwierdzenie, że łatwiej zidentyfikować branże, a właściwie zawody i stanowiska, w których kreatywność nie jest potrzebna.

Na potrzeby badawcze dokonuje się agregacji branż. I tak GUS do przemysłów kultury i kreatywnych według dziedzin kultury zalicza przedsiębiorstwa z obszaru: książki i prasa, sztuki wizualne, edukacja artystyczna, reklama, sztuki audiowizualne i multimedia, dziedzictwo kulturowe, architektura, sztuki performatywne, biblioteki i archiwa. Model brytyjski uwzględnia także rzemiosło, modę, muzykę, działalność związaną z doradztwem w zakresie informatyki. Jest to zakres szeroki, uwzględniający wszystkie, istotne z punktu widzenia kryteriów klasyfikacji grupy podmiotów.

W 2016 r. działalność zaliczaną do przemysłów kultury i kreatywnych prowadziło w Polsce 100,5 tys. podmiotów (wzrost o 10,3\% w stosunku do 2014 r.), zatrudniających 226,7 tys. osób. Miesięczne wynagrodzenie brutto na jednego zatrudnionego w 2016 r. wynosiło średnio 5472 zł. Średnia wartość dodana w latach 2014-2016 została wyliczona na poziomie 21,8 mld zł (Przemysły kultury... 2018). W Wielkiej Brytanii obserwuje się istotny wzrost wartości dodanej brutto (GVA) w 2014 r. w przemyśle kreatywnym o 45,9\% w stosunku do 2009 r. Wartość dodana brutto w 2014 r. była szacowana na 84,1 mld GBP i stanowiła 5,2\% brytyjskiej gospodarki, w tym przemysł IT - 36,6 mld GBP (Creative Industries Economic... 2016). Analiza wskaźników potencjału gospodarczego (m.in. zatrudnienie, przychody, liczba przedsiębiorstw, udział w handlu zagranicznym) wskazują, że mamy do czynienia z sektorem rozwijającym się. Usługi realizowane przez ten sektor dotyczą niemal wszystkich obszarów gospodarki. Nie można zawężać definicji przemysłów kreatywnych do przemysłu kultury. Jest to szansa na wykorzystanie potencjału ludzi po różnych kierunkach studiów (w tym branżowych, ale także humanistycznych czy artystycznych).

Tworzenie się klasy kreatywnej stanowi odpowiedź na różnorodność potrzeb odbiorców produktów i usług, a także dużą konkurencyjność. 
Przewagi konkurencyjne buduje się współcześnie na podstawie unikatowych wyróżników. Produkty i usługi są personalizowane zgodnie $z$ indywidualnymi upodobaniami i potrzebami klientów. Wymaga to pomysłowości, kreatywności i interdyscyplinarności w każdej dziedzinie życia gospodarczego.

\section{Nowy model kompetencji}

Współczesne uwarunkowania gospodarcze wymuszają nowe podejście do uznawania kluczowych czynników warunkujących rozwój. W ramach uproszczonego modelu można przyjąć, że należy posiadać wiedzę (wciąż ją aktualizować), nieustannie się uczyć (w drodze edukacji formalnej i nieformalnej), być kreatywnym (pomysłowym, twórczym, nieszablonowym) i przedsiębiorczym (aktywna postawa), aby się rozwijać. Taki model (schemat 1) odnosi się zarówno do osób, jak i do podmiotów gospodarczych.

Schemat 1. Kluczowe czynniki rozwoju

\section{ROZWóJ} $f$ (wiedza, edukacja, kreatywność, przedsiębiorczość)

Źródło: opracowanie własne.

Funkcję wiedzy, umiejętności i postawy można zdefiniować jako kompetencje. Nie ma jednoznaczności, jakie kompetencje są najbardziej poszukiwane na współczesnym rynku pracy. Oprócz branżowych wymienia się uniwersalne, takie jak: umiejętność rozwiązywania złożonych problemów, krytyczne myślenie, kreatywność, zarządzanie ludźmi, współpraca z innymi, inteligencja emocjonalna, umiejętność oceniania i podejmowania decyzji, zorientowanie na usługi, umiejętność negocjowania, elastyczność poznawcza (The Future of Jobs... 2018). Listę tę warto poszerzyć o kompetencje związane z samodzielną organizacją pracy, gotowość do brania za siebie odpowiedzialności za wykonywanie zadań. Te wszystkie elementy są ważne, ponieważ zmienia się model pracy, następuje istotne spłaszczenie struktur organizacyjnych, a odpowiedzialność za organizację i wykonanie zadań zostaje przesunięta na pracownika. 
Jeszcze trudniejsze wydaje się zdefiniowanie kompetencji przyszłości. W tym miejscu warto odnieść się do wyników badań zespołu z Institute for the Future Uniwersytetu w Phoenix (badania były prowadzone z licznymi partnerami). Naukowcy, posługując się sześcioma zmiennymi, warunkującymi zmiany ${ }^{1}$, przygotowali listę niezbędnych w 2020 r. kompetencji, które będą najważniejsze dla pracodawców. Zauważono, że istotną rolę będą odgrywały kompetencje określane jako ważne już dziś, ale także wiele całkiem nowych. Wśród najważniejszych wymienia się:

$\rightarrow$ zdolność do odkrywania, ale i nadawania głębokiego sensu temu, co chcemy wyrazić (sense making);

$\rightarrow$ inteligencja społeczna, rozumiana jako zdolność do skutecznego komunikowania się, a także budowania relacji międzyludzkich (social intelligence);

$\rightarrow$ myślenie nowatorskie i adaptacyjne (novel and adaptive thinking);

$\rightarrow$ rozumienie różnorodności i praca w wielokulturowym środowisku (cross-cultural competency);

$\rightarrow$ umiejętność pracy z danymi, przetwarzania danych, rozumowania opartego na danych (computational thinking);

$\rightarrow$ umiejętność korzystania z nowych mediów w skutecznej komunikacji (new media literacy);

$\rightarrow$ interdyscyplinarność, wielodziedzinowość (interdyscyplinarity, transdisciplinarity);

$\rightarrow$ myślenie projektowe (design mindset);

$\rightarrow$ zarządzanie kognitywne sobą i innymi (cognitive load management)

$\rightarrow$ zdolność do współpracy wirtualnej (virtual collaboration); (Dziesięć kompetencji... 2017; Dlaczego warto studiować... 2018).

Wszystkie wymienione kompetencje łączy kreatywność. Pozwoli ona na kompleksowe rozwiązywanie bardzo złożonych problemów. Bez wątpienia pracownik przyszłości musi być zorientowany na wynik

Do zmiennych zalicza się: starzenie się społeczeństw oraz wydłużający się czas życia przeciętnego człowieka; wkroczenie na rynek inteligentnych systemów i maszyn (sztuczna inteligencja); rozwój narzędzi komunikacji globalnej (media społecznościowe); przyrost tworzonych informacji na niespotykaną dotąd skalę (informatyzacja świata); ekspansja globalnych korporacji (tj. Google, Twitter etc.); zwiększenie sieci powiązań na różnych poziomach życia ekonomicznego, politycznego i społecznego. 
i sam zarządzać swoją pracą (od etapu planowania, przez organizowanie, motywowanie i kontrolę). Takie podejście wymaga umiejętności kreatywnego łączenia pomysłów, informacji, poszukiwania nowych relacji i związków miedzy obszarami aktywności. Nazywa się to crossowaniem umiejętności.

Wymienione kompetencje osobiste będą miały wpływ na kształt organizacji, a z drugiej strony, zmiany te wymuszają na pracownikach nowe podejście do wykonywanych zadań. Liczyć się będą elastyczność ¡ kreatywność w reakcji na zmiany w otoczeniu. Wiadomo też na pewno, że przyszłość będzie wymagać permanentnego uczenia się (koncepcja lifelong learning). Stwarza to olbrzymie wyzwania dla podmiotów edukacyjnych. Należy pamiętać, że przewidywanie kompetencji przyszłości (także w przemyśle kreatywnym) opiera się na doświadczeniu z przeszłości i wiedzy na temat współczesności. Niestety zjawiska te nie mają charakteru liniowego. Nigdy wcześniej gospodarka nie zmagała się z tak dużą zmiennością, niepewnością, złożonością i niejednoznacznością. A w związku z tym prognozy te są obarczone dużym ryzykiem.

W 2018 r. ukazał się raport Adecco Group $4^{\text {th }}$ Industrial Revolution in Central and Eastern Europe. Innovation and Advantage drive success, który analizuje zmiany, jakie dla gospodarki ( $w$ ściślej rzecz ujmując, dla rynków pracy) niesie dynamiczny rozwój technologii (mających istotny wpływ na przemysł kreatywny). Zauważono, że choć polskie uczelnie kształcą najwięcej przyszłych $\mathrm{CEO}^{2} \mathrm{w}$ regionie, zmagamy się z rosnącym problemem niedopasowania programów kształcenia do potrzeb gospodarki (Kompetencje przyszłości...). Za najważniejsze problemy uznaje się zbyt sztywne ramy kształcenia, brak elastyczności oraz brak nauczania rozwiązywania problemów. Rzeczywistość pokazuje, że przykładowo branża IT staje się bardzo usługowa - rzadko sprzedaje się gotowe produkty, częściej projektuje się rozwiązania odpowiadające potrzebom odbiorców. Autorzy raportu piszą, że „obecnie tradycyjne wykształcenie koncentruje się na teoretycznych, niepraktycznych procesach, mimo że funkcjonujemy w dynamicznym, konkurencyjnym świecie ciągłych zmian". Zmian nie da się uniknąć, nie da się także zwolnić ich tempa. Jedyna możliwa reakcja to dostosowanie się. Autorzy raportu zauważyli, że konieczne jest „wpojenie znaczenia cyfrowej 
inteligencji, ciągłego podnoszenia kwalifikacji i przekwalifikowywania się siły roboczej. Analiza oparta na wiedzy na temat tego, co nas czeka, właściwe przygotowanie się oraz zaakceptowanie idei ciągłego uczenia się w przyszłości to obszary, które autorzy publikacji wskazali jako kluczowe w budowaniu nowoczesnej gospodarki opartej na wiedzy" (Kompetencje przyszłości...).

\section{Koncepcja sektorowych rad ds. kompetencji}

Potrzeba określania kluczowych kompetencji i przygotowywania kadr na potrzeby gospodarcze została dostrzeżona także w Polsce. Polska Agencja Rozwoju Przedsiębiorczości (PARP) od 2017 r. wspiera powstawanie sektorowych rad kompetencji, które są inicjatywami oddolnymi (branżowymi). Aktywnie działające rady rzeczywiście wpływają na ofertę usług edukacyjnych (oferowaną przez szkoły, uczelnie i inne podmioty szkoleniowe). Jest to fantastyczna inicjatywa, w ramach której pracodawcy będą współtworzyć programy kształcenia. To oni najlepiej wiedzą, co należy wzmocnić czy poprawić, jakie są rzeczywiste potrzeby. Badania wskazują, że zapotrzebowanie na kompetencje zmienia się w ciągu życia zawodowego. Bardzo często dochodzi do niezgodności wykonywanej pracy z wykształceniem. W zależności od grupy wiekowej taką zgodność deklaruje między 65\% (18-35 lat) a 85\% (55-70 lat) badanych osób posiadających wyższe wykształcenie. W pozostałych grupach wyróżnionych ze względu na poziom wykształcenia (niższe, średnie) wyniki wahają się między 39 a $64 \%$ (w zależności od wieku). Ta zgodność dotyczy wykształcenia w zakresie zdrowia i opieki społecznej $(94,6 \%)$, technologii teleinformacyjnych $(82,4 \%)$, techniki, przemysłu i budownictwa (79,5\%), nauk przyrodniczych, matematyki i statystyki $(76,5 \%)$, kształcenia $(75,9 \%)$, biznesu, administracji i prawa $(73,7 \%)$, sztuki i nauk humanistycznych (72,9\%), rolnictwa, leśnictwa, rybactwa i weterynarii $(72,2 \%)$ oraz nauk społecznych, dziennikarstwa i informacji (66,8\%), (Bilans Kapitału Ludzkiego 2018).

Wysoko ocenia się przydatność wiedzy i umiejętności wyniesionych ze szkół (ogółem 66\% respondentów) w wykonywanej pracy. Czym osoba jest starsza, tym większe prawdopodobieństwo wyższej oceny. Mężczyźni zazwyczaj wyżej oceniają przydatność zawodową wiedzy i umiejętności wyniesionych ze szkół, a różnice szczególnie widać w przypadku najstarszej kategorii wiekowej (75\% mężczyzn w stosunku do $65 \%$ kobiet). Ocenę przydatności wiedzy wyniesionej ze szkół róż- 
nicują zarówno wiek, jak i wykształcenie respondenta. Zdecydowanie najwyższe oceny wystawiają absolwenci uczelni. W grupie osób w wieku 18-35 lat z wyższym wykształceniem 73\% deklaruje zawodową przydatność wiedzy wyniesionej ze szkół, w grupie 36-54 lata jest to $82 \%$, a 55-70 lat aż 92\% (Bilans Kapitału Ludzkiego 2018).

Dotychczas powstały następujące sektorowe rady kompetencji:

$\rightarrow$ opieka zdrowotna i pomoc społeczna,

$\rightarrow$ budownictwo,

$\rightarrow$ finanse,

$\rightarrow$ turystyka,

$\rightarrow$ motoryzacja i elektromobilność,

$\rightarrow$ moda i innowacyjne tekstylia,

$\rightarrow$ informatyka.

Mimo olbrzymiego potencjału nie ma rady ds. przemysłu kreatywnego. Informatyka i moda występują jako odrębne branże.

\section{Podsumowanie}

Rozważania przedstawione $\mathrm{w}$ rozdziale prowadzą do następujących wniosków:

$\rightarrow$ Przemysł kreatywny jest sektorem o wysokim potencjale rozwojowym, a zawody kreatywne występują w niemal każdej branży.

$\rightarrow$ W nowym modelu kompetencji (wskazującym kluczowe czynniki rozwoju) nie wystarczy już tylko edukacja. Potrzebna jest wiedza (zdobyta także w ramach edukacji nieformalnej i doświadczenia życiowego i zawodowego) i kreatywność (pozwalająca odpowiedzieć na bardzo zindywidualizowane potrzeby klientów).

$\rightarrow$ Wśród najważniejszych kompetencji przyszłości wymienia się inteligencję społeczną, inteligencję emocjonalną, zdolność do odkrywania i nadawania sensu, myślenie kreatywne, rozumienie różnorodności, umiejętność pracy zespołowej z wykorzystaniem najnowszych technologii, zarządzanie sobą.

$\rightarrow$ Szkoły w niewystarczającym stopniu kształtują kompetencje miękkie, jakby nie dostrzegały uwarunkowań współczesnej gospodarki i jej wizji przyszłości. System kształcenia jest sztywny, a chociażby edukacja w zakresie IT, oparta na najnowszych technologiach, musi być elastyczna. Inaczej będziemy uczyć dla przeszłości, a nie dla przyszłości. 
$\rightarrow$ Konieczne jest podejmowanie działań na rzecz jak najlepszego dopasowania oferty edukacyjnej do potrzeb rynku. Dużo się o tym mówi od lat. Rady ds. kompetencji są przykładem dobrych praktyk. Dopasowany model edukacji (skonstruowany na podstawie rekomendacji przedsiębiorców) jest konieczny w tak szybko zmieniającym się świecie. 


$$
5
$$


Wywiady 



\section{Wywiady z przedsiębiorcami i ekspertami}

Rozmowy przeprowadził prof. dr hab. Jan Fazlagić

$\rightarrow$ dr inż. Wojciech Winogrodzki, prezes zarządu T-Matic Grupa Computer Plus Spw z 0.0.;

$\rightarrow$ Arkadiusz Śmigielski, prezes zarządu OptiNav Sp. z o.o.;

$\rightarrow$ Rafał Kupiński, przedsiębiorca i współwłaściciel portalu internetowego z zakresu automatyki przemysłowej i robotyki;

$\rightarrow$ Karol Przybyszewski, członek zarządu Incepton Sp. z o.o.;

$\rightarrow$ Jacek Hanke, prezes zarządu Digital Core Design Sp. z o.o. Sp. k.;

$\rightarrow$ dr Michał Jasieński, prof. Wyższej Szkoły Biznesu - National-Louis University;

$\rightarrow$ dr Dorota Roszkowska, Head of Innovation and Strategy Elastic Cloud Solutions;

$\rightarrow$ Aleksander Sala, dyrektor Kolibro S.A. (DigitalWorkPlace);

$\rightarrow$ dr Wacław Idziak, przedsiębiorca społeczny, propagator koncepcji wiosek tematycznych;

$\rightarrow$ dr Andrzej Wodecki, pracownik naukowy Politechniki Warszawskiej, przedsiębiorca, ekspert w dziedzinie sztucznej inteligencji. 
dr inż. Wojciech Winogrodzki, prezes zarządu T-Matic Grupa Computer Plus Sp. z o.o., firmy dostarczającej rozwiązania wykorzystujące najnowsze technologie gromadzenia i przetwarzania informacji, danych, dokumentów i wiedzy, a także zarządzania nimi i ich udostępniania.

\section{Czy nauczanie kreatywności powinno być zadaniem szkoły,} systemu edukacji? Czy też szkoły powinny koncentrować się na przekazywaniu wiedzy?

Pobudzanie, budowanie i rozwijanie kreatywności uczniów, kształtowanie aktywnego, twórczego, a nie konformistycznego, podejścia do otaczającej rzeczywistości, wyposażanie ich w umiejętność koncepcyjnego, nieszablonowego rozwiązywania problemów - to podstawowe zadania, a jednocześnie wyzwania, przed którymi stoi polska szkoła i cały system edukacji. Na ten wymóg, o wymiarze cywilizacyjnym, składają się trzy czynniki:

$\rightarrow$ postęp techniczny i technologiczny, szczególnie informatyzacja, automatyzacja, robotyzacja, obserwowany zwłaszcza w ostatnich latach rozwój sztucznej inteligencji, które w szybkim tempie i w coraz większym stopniu eliminują popyt na pracę powtarzalną, odtwórczą, poddającą się algorytmizacji i proceduralizacji;

$\rightarrow$ rewolucyjne zwiększenie dostępności do ogólnoświatowych zasobów informacji i wiedzy skodyfikowanej (internet);

$\rightarrow$ jednoczesny lawinowy przyrost wolumenu tych zasobów, czyniący je niemożliwym do opanowania pamięciowego nawet w wąskich dziedzinach specjalizacji;

$\rightarrow$ szybko i systematycznie skracający się okres „przydatności do użycia" tych zasobów, co czyni bezsensownym wyposażanie uczniów w te zasoby.

\section{Czy obserwuje Pan deficyty kreatywności wśród pracowników} zatrudnionych w Pana firmie? Jeśli tak, z czego one wynikają? Jeśli nie, jak wyjaśni Pan ich brak?

Największy poziom obserwowanych deficytów dotyczy: 
$\rightarrow$ kreatywności zbiorowej, tj. umiejętności zespołowego, twórczego rozwiązywania problemów;

$\rightarrow$ umiejętności "domknięcia cyklu kreatywności", czyli nie tylko wygenerowania nowatorskich pomysłów, ale przede wszystkim praktycznego ich wykorzystania i wdrożenia zgodnie z postulatem „od pomysłu do przemysłu”.

\section{Czy chciałby Pan podzielić się jakimiś sugestiami lub} rekomendacjami dla nauczycieli w polskich szkołach odnośnie do nauczania kreatywności i rozwoju kompetencji proinnowacyjnych u uczniów?

Wydaje mi się niezwykle istotne, by oprócz - a może lepiej powiedzieć w ramach - radykalnej zmiany modelu kształcenia położyć szczególny nacisk na identyfikowanie i rozwijanie indywidualnych talentów uczniów, ich zainteresowań i związanej z tym motywacji. Ponadto, w nawiązaniu do mojej odpowiedzi na poprzednie pytanie, postuluję znaczne poszerzenie przestrzeni na formy dydaktyczne rozwijające kompetencje uczniów w zakresie innowacyjności i kreatywności zespołowej. 


\section{Arkadiusz Śmigielski,}

prezes zarządu OptiNav Sp. z o.o.

Czy nauczanie kreatywności powinno być zadaniem szkoły, systemu edukacji? Czy też szkoły powinny koncentrować się na przekazywaniu wiedzy? Proszę uzasadnić odpowiedź.

Jak najbardziej szkoła powinna uczyć kreatywności. Wiedza dziś jest ogólnie dostępna i często uczeń jest w stanie znaleźć tę bardziej aktualną od proponowanej przez nauczyciela. Z punktu widzenia zdobywania wiedzy szkoła się więc dewaluuje. Wciąż jest jednak miejscem, w którym uczeń może i powinien znaleźć inspirację, mentoring i zachętę do samodzielnego odkrywania świata, do innowacyjności i kreatywności.

\section{Czy obserwuje Pan deficyty kreatywności wśród pracowników} zatrudnionych w Pana firmie? Jeśli tak, z czego one wynikają? Jeśli nie, jak wyjaśni Pan ich brak?

W wielu wypadkach tak. Jako uczniowie byli karani przez cały okres szkolny za inne myślenie, za brak kopiowania punktu widzenia nauczyciela, co zabiło w nich chęć do kreatywności.

Czy chciałby Pan podzielić się jakimiś sugestiami lub rekomendacjami dla nauczycieli w polskich szkołach odnośnie do nauczania kreatywności i rozwoju kompetencji proinnowacyjnych u uczniów?

Są trzy elementy, których każdy mądry pracodawca oczekuje od pracownika: podejmowania ryzyka, czyli gotowości do popełniania błędów, pracy zespołowej oraz samodzielnego wyciągania wniosków. Niestety szkoły, poprzez stosowany system oceniania, eliminują te elementy z procesu edukacji. Takie aspekty rozwoju intelektualnego jak kreatywność, innowacyjność, czyli popełnianie błędów i wyciąganie na ich bazie wniosków, są niezauważalne w polskiej edukacji. Za kreatywność i popełnianie błędów szkoła karze negatywnymi ocenami. Dodatkowo system oceniania wzmacnia konkurencję między uczniami, co blokuje pracę zespołową. Może czas zlikwidować oceny, przynajmniej w pewnej części...? Może 
to nauczyciel powinien być oceniany przez ucznia, w końcu to dla ucznia jest szkoła (podobnie jak oceniamy ankietami wykładowców na szkoleniach, bo są dla nas i za nie płacimy). 
Rafał Kupiński, przedsiębiorca i współwłaściciel portalu internetowego z zakresu automatyki przemysłowej i robotyki

Czy nauczanie kreatywności powinno być zadaniem szkoły, systemu edukacji? Czy też szkoły powinny koncentrować się na przekazywaniu wiedzy? Proszę uzasadnić odpowiedź.

Zadaniem szkoły powinno być przekazywanie wiedzy w sposób kreatywny. Co za tym idzie? Uczeń efektywniej i sprawniej przyswaja zdobytą wiedzę, a dodatkowo rozwija w sobie nieszablonowe i kreatywne myślenie.

\section{Czy obserwuje Pan deficyty kreatywności wśród pracowników} zatrudnionych w Pana firmie? Jeśli tak, z czego one wynikają? Jeśli nie, jak wyjaśni Pan ich brak?

Tak, obserwuję deficyt kreatywności wśród pracowników. Pozwalamy rozwinąć skrzydła u nas w zespole i dajemy wolną przestrzeń w rozwiązywaniu zadań. Wynika to przede wszystkim z systemu edukacji. Osoba młoda, która chodzi do szkoły podstawowej i nie myśli jak nauczyciel (lub jak system edukacji), często jest "sprowadzana" na ziemię. Co za tym idzie - taka osoba zamyka się i de facto nie udziela się więcej na lekcjach, zajęciach, ponieważ boi się, wstydzi lub uważa, że jest to złe. Kadra nauczycielska często podchodzi do uczniów jak wyrocznia, że tak jest i już, i nie ma dyskusji. Zabija to kreatywność. Również system oceniania w szkole prowadzi do zamykania się pewnego grona młodych uczniów, ponieważ porównują się często do innych i wolą się nie udzielać, gdyż to z kolei może doprowadzić do przysłowiowej „pały”, a to wystawia go na pośmiewisko i nieprzyjemności. W ten sposób uczeń nie ma luzu i wsparcia, i nie rozwija w sobie kreatywności, którą każdy ma w sobie.

Czy chciałby Pan podzielić się jakimiś sugestiami lub rekomendacjami dla nauczycieli w polskich szkołach odnośnie do nauczania kreatywności i rozwoju kompetencji proinnowacyjnych u uczniów? 
Każdy uczeń ma w sobie dozę kreatywności, jeden mniej, drugi więcej. Nie można negować młodej osoby za jakikolwiek jej przejaw, ponieważ więcej tej kreatywności nie będzie chciała wykazywać. Przede wszystkim rozmowa, znalezienie za i przeciw, znalezienie wspólnie innej drogi, wspólnie jako klasa np. przy rozwiązywaniu napotkanego problemu przez jednego z uczniów. 
Karol Przybyszewski, członek zarządu Incepton Sp. z o.o., firmy dostarczającej rozwiązania data science

Czy nauczanie kreatywności powinno być zadaniem szkoły, systemu edukacji? Czy też szkoły powinny koncentrować się na przekazywaniu wiedzy? Proszę uzasadnić odpowiedź.

Uważam, że nauczanie kreatywności powinno być nieodłączną częścią systemu edukacji. Mechanizmy kreatywności powinny być wbudowane w edukację na możliwie najniższym poziomie. Uczniowie podczas nauki każdego przedmiotu powinni być stawiani przed problemami, gdzie muszą znaleźć niestandardowe, kreatywne rozwiązanie. Samo przekazywanie suchej wiedzy jest bardzo nieefektywne, dzieci szybko się nudzą i przestają przyswajać wiedzę.

\section{Czy obserwuje Pan deficyty kreatywności wśród pracowników} zatrudnionych w Pana firmie? Jeśli tak, z czego one wynikają? Jeśli nie, jak wyjaśni Pan ich brak?

Oczywiście nie wszystkim pracownikom brakuje kreatywności, ale znacznej części na pewno tak. Myślę, że brak kreatywności w dużym stopniu wynika z niechęci do podejmowania ryzyka. Rozwiązanie kreatywne charakteryzuje się większym ryzykiem porażki, więc pracownicy wolą opierać się na standardowych i znanych procedurach, które są może mniej efektywne, ale dają większe prawdopodobieństwo sukcesu. Wynika to zapewne z dwóch ważnych czynników: braku pewności siebie i swoich umiejętności oraz niewykształconej umiejętności szybkiego podnoszenia się z porażek i próbowania nowych rozwiązań. Na pewno ważne są też predyspozycje intelektualne i odpowiednie cechy charakteru.

Czy chciałby Pan podzielić się jakimiś sugestiami lub rekomendacjami dla nauczycieli w polskich szkołach odnośnie do nauczania kreatywności i rozwoju kompetencji proinnowacyjnych u uczniów? Uważam, że trzeba nieustannie się uczyć i uważnie obserwować, co i w jaki sposób motywuje dzieciaki do działania, a następnie przekładać to na działania edukacyjne. Przykłady: 
$\rightarrow$ niezakazywanie telefonów komórkowych na lekcji, ale wykorzystywanie ich do robienia quizów i testów przy użyciu takich narzędzi jak www.menti.com;

$\rightarrow$ używanie gier do wspomagania nauczania, przykładowo World of Tanks do historii broni pancernej, Assasin Creed-pokazanie katedry Notre Dame;

$\rightarrow$ używanie komunikatorów internetowych do kontaktu z uczniami (Messenger, etx);

$\rightarrow$ organizacja małych projektów międzyszkolnych, w których dzieci z różnych szkół muszą nauczyć się współpracy przy stworzeniu $n p$. prezentacji o lasach tropikalnych. 
Jacek Hanke, prezes zarządu Digital Core Design Sp. z o.o. Sp. k., firmy projektującej innowacyjne układy scalone, wśród których są m.in. najszybszy na świecie procesor przemysłowy z rodziny 8051 (DQ80251), pierwszy w historii Polski komercyjny procesor 32-bitowy (D32PRO) oraz w $100 \%$ bezpieczny system kryptograficzny (CryptOne)

\section{Czy nauczanie kreatywności powinno być zadaniem szkoły, systemu edukacji? Czy też szkoły powinny koncentrować się na przekazywaniu wiedzy? Proszę uzasadnić odpowiedź.}

Myślę, że nie zaskoczę swoją odpowiedzią, ale jestem zwolennikiem tzw. złotego środka. Zatem moim zdaniem szkoła powinna być tą instytucją, która w usystematyzowany sposób przekazuje wiedzę, ale przy realizacji tego postulatu wyzwala również naturalne pokłady kreatywności, które drzemią w naszych dzieciach. Konstatacja ta wynika nie tylko z analizy bieżącej sytuacji w systemie edukacji, ale również - czy też przede wszystkim - z doświadczenia pracy (krótkiej, co prawda) w szkole publicznej. Ponadto firma Digital Core Design aktywnie uczestniczy w obchodach Światowego Dnia Przedsiębiorczości, w trakcie których uczniowie okolicznych szkół średnich mają możliwość poznania specyfiki pracy w naszej firmie. Umożliwiamy również studentom odbycie praktyk i staży, dzięki którym mogą zweryfikować swoją wiedzę teoretyczną z aktualnym zapotrzebowaniem rynkowym. Wspominam o tych inicjatywach nieprzypadkowo, bowiem młodzi ludzie, czy to w szkołach średnich, czy na studiach, wykazują się dużym potencjałem i kreatywnością, które to cechy w połączeniu z solidną wiedzą teoretyczną są katalizatorem pożądanych zmian. Dlatego też, reasumując - nauka musi iść w parze z kreatywnością.

\section{Czy obserwuje Pan deficyty kreatywności wśród pracowników} zatrudnionych w Pana firmie? Jeśli tak, z czego one wynikają? Jeśli nie, jak wyjaśni Pan ich brak?

Digital Core Design w 2019 r. obchodzi jubileusz 20-lecia działalności firmy i muszę w tym miejscu jednoznacznie przyznać, że jakikolwiek 
deficyt kreatywności byłby jednocześnie końcem DCD. W tak trudnej branży jak IT, którą cechują permanentne innowacje - to właśnie kreatywność nabiera szczególnego znaczenia. Pokusiłbym się nawet o dalej idącą konstatację - to właśnie swoisty miks zdobytej wiedzy i wrodzonej kreatywności są gwarancją sukcesu naszej firmy.

\section{Czy chciałby Pan podzielić się jakimiś sugestiami lub} rekomendacjami dla nauczycieli w polskich szkołach odnośnie do nauczania kreatywności i rozwoju kompetencji proinnowacyjnych u uczniów?

Co prawda moja przygoda z pracą nauczyciela trwała bardzo krótko, jednakże dzięki zobowiązaniom rodzinno-towarzyskim mam dość dobry wgląd w bieżącą sytuację polskiego systemu edukacji. Widać w nim wyraźną dychotomię - każdy z nas jest w stanie wskazać nauczycieli, którzy przekazują wiedzę według minimum programowego, oraz takich, dla których przekazywanie wiedzy to sztuka - gdzie w parze z wiedzą idzie pobudzanie kreatywności i wrodzonej ciekawości otaczającego świata. To właśnie ta druga grupa powinna być dodatkowo motywowana, nie tylko materialnymi środkami. W tym miejscu upatruję dużej roli przełożonych, którzy powinni motywować i wspierać nauczycieli, którym chce się więcej. Nagradzanie ich zaangażowania i nierzadko mentorskiej roli nie powinno być traktowane jako koszt, ale raczej jako inwestycja, która w bardzo krótkim czasie zwraca się po wielokroć. 
dr Michał Jasieński, prof., prorektor ds. badawczorozwojowych, Centrum Innowatyki Wyższej Szkoły Biznesu - National-Louis University

Czy nauczanie kreatywności powinno być zadaniem szkoły, systemu edukacji? Czy też szkoły powinny koncentrować się na przekazywaniu wiedzy? Proszę uzasadnić odpowiedź.

Trudno przewidzieć, jaką wiedzę przekazać uczniom, skoro świat zmienia się coraz szybciej i nie mogą za tym nadążyć żadne podstawy programowe, pisane przecież nie przez milenialsów, tylko przez pokolenia przedfejsbukowe. Jeżeli wiedza, to raczej o metodach rozwiązywania problemów (zwłaszcza metodach ilościowych, opartych na matematyce i statystyce). Kreatywność - tak, ale trzeba uważać, aby nie była to propedeutyka kreatywności (czyli uczenie o klasyfikacji metod heurystycznych i o procedurach tworzenia sesji kreatywnego myślenia), tylko aktywne i rzeczywiste generowanie rozwiązań poprzez stosowane metody heurystyczne. Uczenie się przez robienie i tworzenie, a nie przez wkuwanie teorii.

\section{Czy obserwuje Pan deficyty kreatywności wśród pracowników} zatrudnionych w Pana firmie? Jeśli tak, z czego one wynikają? Jeśli nie, jak wyjaśni Pan ich brak?

Zdecydowanie tak. Po pierwsze, wynikają one z hierarchicznej natury relacji obserwowanych na uczelni oraz wysoce demoralizującej, aczkolwiek nieformalnej, terminologii, dzielącej pracowników na "samodzielnych" i tych innych, czyli, w domyśle, niezdolnych do samodzielności - w myśleniu i działaniu. Kreatywność wymaga wewnętrznego przekonania, że mogę, bez pytania zwierzchnika o zgodę, o zatwierdzenie, o zaparafowanie. W kalifornijskiej firmie IDEO stosowana jest reguła: „nie proś o zgodę; rób, a jak ktoś zaprotestuje, wtedy proś o wybaczenie" - to bardziej sprzyja kreatywności.

Po drugie, deficyty kreatywności są wypadkową nauki w szkole - polegającej na przycinaniu, musztrowaniu i tuczeniu wiedzą, a nietolerującej prawdziwego fermentu i burzy mózgów. Pracownik nie wie, że szukanie rozwiązań polega na eksploracji nieznanego, 
ponieważ przyzwyczaił się, że jedyną metodą jest znalezienie w książce gotowych receptur postępowania albo zapytanie "dorosłego", bezradnie jak dziecko. W mojej firmie (uczelnia wyższa) najlepiej widać to podczas seminariów naukowych: młodzi pracownicy w ogóle nie umieją się odezwać i sformułować pytania lub komentarza (pomijam oczywiście to, że - zgodnie z punktem pierwszym - każde pytanie lub komentarz odebrane są na ogół jako arogancki atak na prelegenta, jeżeli jest starszy wiekiem lub miejscem w hierarchii akademickiej).

\section{Czy chciałby Pan podzielić się jakimiś sugestiami lub} rekomendacjami dla nauczycieli w polskich szkołach odnośnie do nauczania kreatywności i rozwoju kompetencji proinnowacyjnych u uczniów?

Nauczyciele najczęściej wolą mieć na lekcji uczniów odpowiednio onieśmielonych: autorytetem nauczyciela oraz wagą tematów. Uczniowie tacy są po prostu łatwiejsi w obróbce i szybszym przerabianiu materiału. Ośmieleni uczniowie to kłopot: trzeba z nimi rozmawiać i, co gorsza, próbować rozumieć, co mają nam do powiedzenia. Prościej jest nazwać ich bezczelnymi i kazać siedzieć cicho. Paradoks polega na tym, że bez umiejętnego zarządzania takimi uczniami nie uda się nam wykrzesać z nich prawdziwej kreatywności.

Metody heurystyczne mają to do siebie, że na ogół nie działają bez pewnego luzu, zabawy, uwolnienia od konwenansów i wręcz zachęcania (ze strony nauczyciela) do bycia intelektualnie "niegrzecznym". Skojarzenia stymulowane słowami losowymi lub obrazkami nie mogą podlegać autocenzurze w głowach uczniów, ponieważ jest to jednoznaczne z gubieniem (być może) najcenniejszych pomysłów - tych najbardziej "odjechanych", niekonwencjonalnych, nieuczesanych. Później, w fazie oceny, łatwo takie pomysły odrzucić, jeżeli okażą się nierealistyczne, ale niełatwo je wygenerować, gdyż powstają z niczego, czyli z głowy. 
dr Dorota Roszkowska, Head of Innovation and Strategy w Elastic Cloud Solutions, firmie produkującej nowoczesne oprogramowanie dla przedsiębiorstw, umożliwiające stworzenie w pełni cyfrowego miejsca pracy

Czy nauczanie kreatywności powinno być zadaniem szkoły, systemu edukacji? Czy też szkoły powinny koncentrować się na przekazywaniu wiedzy? Proszę uzasadnić odpowiedź.

Szkoła nie może nauczyć kreatywności, może ją pobudzać lub hamować. Zadaniem systemu edukacji jest przekazywanie wiedzy, ale także, a może przede wszystkim, nauka logicznego rozumowania, umiejętności wykorzystania dostępnych źródeł wiedzy w celu rozwiązywania zdań i problemów, zdolności formułowania wypowiedzi i argumentowania swoich racji. Tam, gdzie nie ma sztywnych reguł i zasad, które określają, co jest jednoznacznie właściwe lub nie, pojawia się miejsce na kreatywność.

Czy obserwuje Pani deficyty kreatywności wśród pracowników zatrudnionych w Pani firmie? Jeśli tak, z czego one wynikają? Jeśli nie, jak wyjaśni Pani ich brak?

Zdarza się, że pracownicy mają opory przed tym, by wyjść z inicjatywą lub zaproponować nowy sposób rozwiązania problemów. Nie określiłabym tego jako deficyt kreatywności, a obawę przed porażką, brakiem akceptacji pomysłu przez resztę zespołu. Żaden pracownik wyposażony w odpowiednie narzędzia i funkcjonujący w warunkach otwartości i tolerancji błędów nie ma problemów z wygenerowaniem niestandardowych pomysłów i rozwiązań.

Czy chciałaby Pani podzielić się jakimiś sugestiami lub rekomendacjami dla nauczycieli w polskich szkołach odnośnie do nauczania kreatywności i rozwoju kompetencji proinnowacyjnych u uczniów?

Proponuję wprowadzenie zaliczeń z niektórych przedmiotów na podstawie wykonania przez uczniów konkretnych projektów, a nie na zasadzie przyswojenia pamięciowego materiału z podręcznika. 
Aleksander Sala, dyrektor, Kolibro S.A. (DigitalWorkPlace), jednego z liderów w Polsce w zakresie rozwiązań ułatwiających komunikację wewnętrzną w firmach

\section{Proszę o podzielnie się swoimi radami dla nauczycieli i ich przełożonych. Co powinniśmy zmienić w polskim systemie edukacji, aby kształcił innowatorów?}

Z przyjemnością i nadzieją wypowiadam się w tej kwestii. Moje podpowiedzi są następujące:

$\rightarrow$ Zakładanie, że uczący się są lepsi od nauczycieli. Ja, kiedy szkolę swoich pracowników czy klientów z innowacyjności czy w opracowywaniu zmian, to zawsze mam nadzieję, że są i będą lepsi ode mnie. Warto więc myśleć, że „w mojej klasie siedzą wynalazcy, artyści światowej klasy, potentaci w biznesie". To da im pewność siebie, którą poniosą $w$ dorosłe życie i karierę zawodową.

$\rightarrow$ W kreatywności nie ma ocen, tych szkolnych. Miarą kreacji jest wspólny sukces i radość z podważenia status quo, kiedy patrzymy na nowy efekt, obraz itd. Drodzy Nauczyciele, waszą rolą jest motywowanie, a nie ocenianie.

$\rightarrow$ Konstruktywnie się kłócić i dociekać. Nie ma jednej odpowiedzi, jednej prawdy, jednego rozwiązania. To leży u podstaw kreatywności. Nam przedsiębiorcom potrzebni są ludzie potrafiący bronić swoich racji i „walczący”.

$\rightarrow$ Jako przedsiębiorca liczę bardzo, że proces nauczania będzie wyzwalał w ludziach to, co najlepsze, zamiast powodować kompleksy. Niestety spotykam się nie tylko z niskim poziomem kreatywności i brakiem umiejętności pracy z zespole, ale przede wszystkim szybką rezygnacją przy najmniejszych przeszkodach i pierwszych niepowodzeniach.

$\rightarrow$ Polecam przeczytanie książki Malcolma Gladwella Błysk wspaniałe przykłady, jak uwalnia się kreatywność.

$\rightarrow$ Program powinien być pomocą lub inaczej - jednym z trzech filarów nauczania. Drugi to bodźce zewnętrzne, to, co nas inspiruje na co dzień, ludzie, książki, internet. Trzeci to zdefiniowane zadania i cele do osiągnięcia - czyli jak np. zmienić 
świat, jaka będzie najlepsza lokalizacja dla CPL. Innowacje i odkrycia rodzą się niespodziewanie, przy sprzyjającej aurze, w otoczeniu medialnym, w dyskusjach. 
dr Wacław Idziak, przedsiębiorca społeczny, propagator koncepcji wiosek tematycznych jako metody rozwoju polskiej wsi

\section{Proszę o podzielnie się swoimi radami dla nauczycieli i ich przełożonych. Co powinniśmy zmienić w polskim systemie edukacji, aby kształcił innowatorów?}

System edukacji działa wedle paradygmatu: wiedza - umiejętności - postawy, wydaje mi się, że powinno być raczej odwrotnie: postawy - umiejętności - wiedza. Ten odwrócony paradygmat przypomina sposób uczenia w układzie mistrz - uczeń, terminowania w warsztacie rzemieślniczym. Edward de Bono, pisząc o tym, co będzie ważne w obecnym tysiącleciu, podkreśla, że coraz trudniej uczyć się w ogóle, uczyć się na zapas. Według niego uczenie się powinno być podporządkowane projektowaniu własnej przyszłości. A projektowanie to powinno mieć oparcie w pasjach, zainteresowaniach, emocjach, czyli właśnie w postawach. Kiedy coś lubimy, czymś się pasjonujemy, to chętniej się tym zajmujemy, to wiedza przychodzi jakby sama. Jest to też jedna z tez neurodydaktyki.

W edukacji powinien być większy udział uczenia się w działaniu, w realnych, prawdziwych, a nie symulowanych okazjach do uczenia się.

Coraz częściej studenci uczą się i pracują. Niekiedy ich praca wiąże się z kierunkiem studiów. Wydaje mi się jednak, że do rzadkości należy włączanie pracy studentów w tok studiowania. Tak się dzieje w uniwersytetach określanych jako przedsiębiorcze (entrepreneurial universities).

Innowacyjne kształcenie wymaga innej organizacji przestrzeni do uczenia się, to nie może już być tradycyjna klasa czy sala wykładowa. Już Jan Ámos Komenský pisał: „Należy ludzi, o ile to możliwe, uczyć mądrości nie z książek, lecz z nieba, ziemi, dębów i buków, tj. poznawać i badać same rzeczy, a nie tylko cudze spostrzeżenia i świadectwa, dotyczące tych rzeczy. Wykształcenie wielu, jeśli nie przeważnej ilości ludzi, staje się tylko czystą nazwą, tj. umieją oni wprawdzie wymienić terminy i zasady umiejętności, ale nie umieją ich należycie zastosować". 
Jak organizować dzisiaj przestrzenie do twórczego uczenia się, jak uczyć w lesie, ogrodzie, poprzez teatr, studio nagrań, w restauracji, w podróży itp.?

Wielką przeszkodą w kształceniu dla innowacji jest tradycyjnie pojmowana siatka zajęć. Lepiej do tego służy uczenie się systemem blokowym stosowane w niektórych szkołach (uniwersytetach). Dany przedmiot (zestaw przedmiotów) „przerabiany” jest przez kilka tygodni od początku do zaliczenia, potem studenci zajmują się następnym zagadnieniem. Wymaga to innego systemu zatrudniania nauczycieli, ale też sprzyja zatrudnianiu na uczelniach ludzi znających nauczane zagadnienia od strony praktycznej.

Utrudnieniem w kształceniu dla innowacji jest podział na przedmioty nauczania, szufladkujący wiedzę i utrudniający jej interdyscyplinarne pojmowanie i wykorzystywanie. Przykładem odchodzenia od uczenia się w ramach przedmiotów jest fiński system edukacji.

Innowacyjne kształcenie jest rodzajem sztuki, artyzmu, stąd istotne jest łączenie uczenia się, włączanie do uczenia się: poezji, teatru, muzyki, kuglarstwa, pracy rąk, uprawiania ogrodu, ruchu wszelkiego itp.

Margaret Mead w książce Kultura i tożsamość - studium dystansu międzypokoleniowego dzieli kultury na trzy grupy:

$\rightarrow$ przeszłość - kultury postfiguratywne, dzieci uczą się głównie od swych rodziców, starszych, nauczycieli;

$\rightarrow$ teraźniejszość - kultury kofiguratywne, zarówno dzieci, jak i dorośli uczą się także od swych rówieśników;

$\rightarrow$ przyszłość - kultury prefiguratywne, dorośli uczą się również od swych dzieci.

Przyjęcie zasadności tezy o prefiguratywności może sugerować, że uczenie się, szczególnie "kształcenie dla innowacji", powinno odbywać się w zespołach różnowiekowych. 
dr Andrzej Wodecki, pracownik naukowy Politechniki Warszawskiej, przedsiębiorca, ekspert w dziedzinie sztucznej inteligencji

\section{Proszę o podzielnie się swoimi radami dla nauczycieli i ich przełożonych. Co powinniśmy zmienić w polskim systemie edukacji, aby kształcił innowatorów?}

Innowacyjność jest zbyt szerokim i często nadużywanym pojęciem. Z mojej perspektywy zdecydowanie ważniejsze są wytrwałość, myślenie krytyczne i analityczne oraz zdolność uczenia się. Co więcej, zbyt duża liczba przedmiotów kreatywnych rozbudza tendencje do marzycielstwa, przekonania, że wszystko potrafimy zrobić, natomiast w rzeczywistości sam pomysł to tylko $5 \%$ sukcesu - reszta to ciężka praca nad dostarczeniem rezultatu. W efekcie młodzi ludzie na początku kariery zawodowej są sfrustrowani: przekonani, że wszystko osiągną bez wysiłku, zderzają się z rzeczywistością, w której dostarczenie nawet prostego produktu wymaga bardzo dużego zaangażowania. Dlatego rekomenduję zmiany systemu edukacji w kierunku nie innowacyjności, ale rozwijania siły i pokory do ciężkiej pracy, zwłaszcza w obszarze nauk przyrodniczych i computational thinking. 


\section{Bibliografia}

$\rightarrow$ Abdous, M.H. (2011), A process-oriented framework for acquiring online teaching competencies, „Journal of Computing in Higher Education”, 23 (1), s. 60-77.

$\rightarrow$ Alencar, E.M.L.S. (2012), Creativity in Organizations: Facilitators and Inhibitors [w:] M. Mumford, Handbook of Organizational Creativity, Cambridge, MA: Academic Press.

$\rightarrow$ Allan, D., Kingdon, M., Murrin, K., Rudkin, D. (2002), Sticky Wisdom, How to Start a Creative Revolution at Work, Capstone: North Mankato, MN, s. 14-30.

$\rightarrow$ Almeidaa, C., Moldovanb, L. (2013), Mobile learning methodology for European trainers and VET systems quality improvement. The 7th International Conference Interdisciplinarity in Engineering (INTER-ENG 2013).

$\rightarrow$ Alpaugh, P.K., Birren, J.K. (1977), Variables affecting creative contributions cross the adult life span, and normative commitment to the organization: A meta-analysis of antecedents, „Human Development”, 20, s. 240-248.

$\rightarrow$ Altszuller, G.S. (1972), Algorytm wynalazków, Warszawa: Omega.

$\rightarrow$ Altszuller, G.S. (1983), Elementy teorii twórczości inżynierskiej, Warszawa: Wydawnictwa Naukowo-Techniczne.

$\rightarrow$ Amabile, T.M. (1983), The social psychology of creativity: A componential conceptualization, „Journal of Personality and Social Psychology”, 45 (2), s. 357-376.

$\rightarrow$ Amabile, T.M. (1997), Motivating creativity in organizations: on doing what you love and loving what you do, "California Management Review", 40 (1), s. 39-58.

$\rightarrow$ Apelojg, B. (2016), Process-Oriented Didactics, Ideas for the Advancement of Teaching and Learning. For the Cowboy on the Right Path!, bit.ly/2NZ69i6 [dostęp: 3.05.2017].

$\rightarrow$ Bales, P., Smith, J. (2008), The fascination of wisdom: its nature, ontogeny, and function, „Psychological Science”, 3 (1), s. 122-136. 
$\rightarrow$ Barron, F. (1955), The disposition toward originality " The Journal of Abnormal and Social Psychology", 51 (3), s. 478.

$\rightarrow$ Bartkowiak, G. (2016), Zatrudnianie pracowników wiedzy 65 plus. Perspektywa pracowników i organizacji, Toruń-Warszawa: Wydawnictwo Adam Marszałek, Akademii Finansów i Biznesu, Vistula.

$\rightarrow$ Bauer, R. (2003), Offenes Arbeiten in der SEK I, Berlin: Cornelsen Verlag.

$\rightarrow$ Bawarskie Ministerstwo Oświaty, Kultury, Nauki i Sztuki (2017a), Wettbewerb fördert unternehmerisches Denken an den Schulen, bit.ly/31ZCDf8 [dostęp: 2.05.2017].

$\rightarrow$ Bawarskie Ministerstwo Oświaty, Kultury, Nauki i Sztuki (2017b), JUNIOR-Programme fördern kreative Jungunternehmer, bit.ly/2YszToB [dostęp: 2.05.2017].

$\rightarrow$ Bawarskie Ministerstwo Oświaty, Kultury, Nauki i Sztuki (2017c), Einmal selbst Banker sein, www.km.bayern.de/schueler/meldung/4420/einmal-selbst-banker-sein.html [dostęp: 2.05.2017].

$\rightarrow$ Bawarskie Ministerstwo Oświaty, Kultury, Nauki i Sztuki (2017d), Hervorragende Seminararbeiten zu Wirtschaftsthemen gesucht, www.km.bayern.de/schueler/ meldung /3238/hervorragende-seminararbeiten-zu-wirtschaftsthemen-gesucht.html [dostęp: 30.04.2017].

$\rightarrow$ Bawarskie Ministerstwo Oświaty, Kultury, Nauki i Sztuki (2017e), Schueler entdecken das Thema Wirtschaft, www.km.bayern.de/schueler/meldung/2195/ schueler-entdecken-das-themawirtschaft.html [dostęp: 30.04.2017].

$\rightarrow$ Bawarskie Ministerstwo Oświaty, Kultury, Nauki i Sztuki (2017f), www.km.bayern.de/schueler/meldung/3818/wettbewerb-praemiert-junge-weltraumforscher.html [dostęp: 30.04.2017].

$\rightarrow$ Bawarskie Ministerstwo Oświaty, Kultury, Nauki i Sztuki (2017g), Die wichtigsten Austauschprogramme, bit.ly/2JbUwjL [dostęp: 30.04.2017].

$\rightarrow$ Baylon Ch., Mignot, X. (2005), Komunikacja, Kraków: FLAIR, s. 158.

$\rightarrow$ Beblavý, M., Veselková, M. (2014), Future of Skills in Europe, Convergence or polarisation?, CEPS Working Document, 390/luty.

$\rightarrow$ Benedyk, M., Jauk, E., Sommer, M., Arendasy, M., Neubauer, A.C. (2014), Intelligence, creativity, and cognitive control: the common and differential involvement of executive functions in intelligence and creativity, „Intelligence”, 46, s. 73,83 .

$\rightarrow$ Bennis, W., Biederman, P.W. (2007), Organizing Genius: The Secrets of Creative Collaboration, New York: Basic Books.

$\rightarrow$ Bieniok, H. (2014), Kreatywność jako źródło nowoczesności i rozwoju przedsiębiorstw, Zeszyty Naukowe Politechniki Śląskiej, Seria: Organizacja i zarządzanie, 73 (1919). 
$\rightarrow$ Bilans Kapitału Ludzkiego 2017 (2018), Raport z badania ludności w wieku 18-70 lat, Warszawa: Polska Agencja Rozwoju Przedsiębiorczości.

$\rightarrow$ Blachelet, M. (2018), Ignorując zmiany klimatyczne igramy z ogniem, "Magazyn Turning Points. Global Agenda 2019. Wydarzenia, które odmieniły twoje życie", "Gazeta Wyborcza", 29-30 grudnia, s. 30-31.

$\rightarrow$ Błaszczak, A. (2017), Młodzi bardziej otwarci na pracę w innym mieście , Rzeczpospolita", 21.06.2017.

$\rightarrow$ Brav, A., Andersson, K., Lantz, A. (2009), Group initiative and self-organizational activities for a Caring Profession, "Journal of Nurshing Education”, 48 (7), s. 347-377.

$\rightarrow$ Brookhart, S.M. (2010), How to Assess Higher-order Thinking Sskills in Your Classroom, Alexandria, VA: ASCD.

$\rightarrow$ Brookhart, S.M. (2013), How to Create and Use Rubrics for Formative Assessment and Grading, Alexandria, VA: ASCD.

$\rightarrow$ Brown, D. (2010), Podręcznik rozwijania kreatywności: sztuka i twórczość w pracy z dziećmi, Kielce: Wydawnictwo Jedność.

$\rightarrow$ Brown, S.D. (2010), A process-oriented guided inquiry approach to teaching medicinal chemistry , „American Journal of Pharmaceutical Education”, 74 (7), s. 121.

$\rightarrow$ Brunello, G., Lorena Conti, S., Sonedda, D. (2012), Training subsidies and the wage returns to continuing vocational training: Evidence from Italian, „Labour Economics", 19 (3), s. 361-372, www.sciencedirect.com [dostęp: 2.05.2019].

$\rightarrow$ Businessballs.com staff (b.d.w.), Kirkpatrick's learning and training evaluation theory, bit.ly/2JKFFwJ [dostęp: 11.04.2019].

$\rightarrow$ Buxton, B. (2010), Sketching User Experiences: Getting the Design Right and the Right Design, Burlington, MA: Morgan Kaufmann.

$\rightarrow$ Buzan, T., Keene, R. (1997), Księga Geniuszu. Jak wyzwolić geniusza w sobie, Radom-Warszawa: Ośrodek Kształcenia i Doskonalenia Kadr Instytutu Technologii Eksploatacji - Ministerstwo Edukacji Narodowej, s. 15.

$\rightarrow$ Cachia, R., Ferrari, A., Ala-Mutka, K., Punie, Y. (2010), Creative Learning and Innovative Teaching. Final Report on the Study on Creativity and Innovation in Education in the EU Member States, IRC EC, Luxembourg: Publications Office of the European Union.

$\rightarrow$ Carper, J. (2010), Nasz wspaniały mózg, czyli jak zachować bystrość, sprawność i jasność umysłu, Poznań: Vesper.

$\rightarrow$ Carvey, C.S. (2001), Affect and the Functional Bases of Behavior. On Dimensional Structure and Effective Experience, „Personality and Social Psychology Review", 5, s. 345-356. 
$\rightarrow$ CEDEFOP (2012), From education to working life. The labour market outcomes of vocational education and training, bit.ly/2LaZUFS [dostęp: 30.03.2019].

$\rightarrow$ CEDEFOP (2016), Future Skill Needs in Europe: Critical Labour Force Trends, Luxembourg: Publications Office, CEDEFOP research paper, 59.

$\rightarrow$ Centrum Szkolne Wilhelm-Raabe-Schulzentrum Eschershausen (2017a), Berufsorientierung einmal ganz anders!, bit.ly/329wm 05 [dostęp: 4.05.2017].

$\rightarrow$ Chabior, A. (2017), Wspomaganie procesu pomyślnego starzenia się u ludzi starych. Między powinnościq a profesjq, Kraków: Oficyna Wydawnicza „Impuls".

$\rightarrow$ Chamorro-Premuzic, T. (2018), Ciemna strona kreatywności, „Harvard Business Review Polska", bit.ly/2LoX940 [dostęp: 10.01.2018].

$\rightarrow$ Chandler, M.J., Holliday, S. (1990), Wisdom is a postapocalyptic age [w:] R.J. Sternberg (red.), Wisdom: Its Nature, Origins and Development, Cambridge: Cambridge University Press, s. 121-141.

$\rightarrow$ Chełmiński, J. (2019), Co Warszawa może zrobić dla klimatu, rozmowa z Moniką Sadkowską, "Magazyn Warszawa”, "Gazeta Wyborcza”, 10 maja, s. 8.

$\rightarrow$ Chen, C.Y., Chen, P.C., Chen, P.Y. (2014), Teaching quality in higher education: an introductory review on a process-oriented teaching-quality model, "Total Quality Management \& Business Excellence", 25 (1/2), s. 36-56.

$\rightarrow$ Coate, K., Boulos, A. (2012), Creativity in education: challenging the assumptions, „London Review of Education”, 10 (2), s. 129-132, DOI: 10.1080/14748460.2012.691278 [dostęp: 30.07.2019].

$\rightarrow$ ConAct (2017), Über uns, www.conact-org.de/ueber-uns/ [dostęp: 30.04.2017].

$\rightarrow$ Corporations, Creativity and Consumers (2016), „TRUE", 12/sierpień.

$\rightarrow$ Crackton, P. (1987), The Loonie: God's long-awaited gift to colourful pocket change , "Canadian Change", 64 (7), s. 34-37.

$\rightarrow$ Cranmer, S. (2014), Digital Skills and Competencies in Schools, IFIP Conference on Information Technology in Educational Management (ITEM) and IFIP Conference on Key Competencies for Educating ICT Professionals (KCICTP), Potsdam, s. 165-177.

$\rightarrow$ Creative Industries Economic Estimates January 2016, Department for Culture, Media and Sport, United Kingdom 2016, https://assets.publishing.service.gov. uk [dostęp: 2.04.2019].

$\rightarrow$ Creative Industries Mapping Document, Development for Culture, Media and Sport (2001), London, cyt. za: Głowacki J. (2013), Przemysły kreatywne i ich wpływ na gospodarkę [w:] J. Hausner, A. Karwińska, J. Purchla (red.), Kultura a rozwój, Warszawa: Narodowe Centrum Kultury.

$\rightarrow$ Csíkszentmihályi, M. (1996), The creative personality, „Psychology Today”, 1 lipca. 
$\rightarrow$ Csíkszentmihályi, M., Getzels, J.W. (1971), Discovery-oriented behavior and the originality of creative products: a study with artists, „Journal of Personality and Social Psychology", 19 (1), s. 47.

$\rightarrow$ Curtis, D. (2010), Defining, Assessing and Measuring Generic Competences, Adelaide: University of South Australia.

$\rightarrow$ Czerwanski, A., Solzbacher, C. (2004), Förderung von Lernkompetenz in der Schule - Praxisbeispiele, Gütersloh: Verlag Bertelsmann.

$\rightarrow$ Czym jest hamowanie?, bit.ly/2YOuDvc [dostęp: 20.01.2018].

$\rightarrow$ Daly, S.R., Mosyjowski, E.A., Seifert, C.M. (2014), Teaching creativity in engineering courses, „Journal of Engineering Education”, 103 (3), s. 417-449.

$\rightarrow$ Daszkiewicz, N. (2014), Education as a stimulating factor for entrepreneurship development, „Horyzonty Wychowania”, 13 (26), s. 165-177.

$\rightarrow$ Davies, A., Fidler, D., Gorbis, M. (2011), Future Work Skills 2020, Phoenix, AZ: Institute for the Future for the University of Phoenix Research Institute.

$\rightarrow$ de Bono, E. (2008), Kurs myślenia, Łódź: BBC Active Inteligencja.

$\rightarrow$ Definicja zdrowia i jakości życia wg WHO, gabinetzdrowia.net.pl/definicja-zdrowia-i-jakosci-zycia-wg-who.php [dostęp: 10.08.2019].

$\rightarrow$ Department for Education and Employment (2000), Skills for All: Research Report from the National Skills Task Force, dera.ioe.ac.uk//15164 [dostęp: 4.04.2019].

$\rightarrow$ Deutscher bildungs server (2017), Bildungssysteme der Länder in der Bundesrepublik Deutschland, bit.ly/2FOURXp [dostęp: 3.05.2017].

$\rightarrow$ Dlaczego warto studiować w Instytucie Spraw Publicznych UJ (2018), bit.ly/ 2GjRw2N [dostęp: 6.04.2019].

$\rightarrow$ Domaradzki, K. (2018), Józef Hoffman - genialny muzyk, który wynalazł spinacz i wycieraczki samochodowe, bit.ly/2LOZKya [dostęp: 29.12.2017].

$\rightarrow$ Dreier, R. (2012), Medien im Unterricht, 28.10.2012, bit.ly/2L5Sa82 [dostęp: 4.05.2017].

$\rightarrow$ Drucker, P. (1954), The Practice of Management, New York, NY: Harper \& Row.

$\rightarrow$ Dubas, E., Muszyński M. (2016), Obiektywny i subiektywny wymiar starości, Łódź: Wydawnictwo Uniwersytetu Łódzkiego.

$\rightarrow$ Dweck, C.S. (2009), Mindsets: developing talent through a growth mindset, "Olympic Coach", 21 (1), s. 4-7.

$\rightarrow$ Dweck, C. (2012), Mindset: Changing the Way You Think to Fulfil Your Potential, London: Hachette.

$\rightarrow$ Dzięgielewska, M. (2006), Aktywność społeczna i edukacyjna w fazie starości [w:] B. Szatur-Jaworska, P. Błędowski, M. Dzięgielewska (red.), Podstawy gerontologii społecznej, Warszawa: ASPRA-JR. 
$\rightarrow$ Dziesięć kompetencji przyszłości. Najważniejsze umiejętności w 2020 roku (2017), bit.ly/2XGXNjl [dostęp: 16.04.2019].

$\rightarrow$ Eberhard, J.P., Patoine, B., (2004), Architecture With the Brain in Mind. The Dana Foundation weblog, bit.ly/2ShcYu4 [dostęp: 10.09.2017].

$\rightarrow$ Eckhardt, R. (2017), Schuldenprävention, bit.ly/2XqOqQn [dostęp: 4.05.2017].

$\rightarrow$ EU Council of Ministers (2009), Council conclusions on a strategic framework for European cooperation in education and training, bit.ly/2Z7S2bn [dostęp: 4.04.2019].

$\rightarrow$ European Commission (2016), Besonderheiten des deutschen Bildungswesens, bit.ly/2LF1fnV [dostęp: 4.05.2017].

$\rightarrow$ European Union (2010), Joint Progress Report of the Council and the Commission on the implementation of the 'Education and Training 2010 work programme', C 117/01.

$\rightarrow$ Fazlagić, J. (2015), Kreatywni w biznesie, Warszawa: Poltext.

$\rightarrow$ Fazlagić, J. (2017), Szkoła dla innowatora. Opis skrócony projektu zrealizowanego na zlecenie Ministerstwa Rozwoju RP, Kalisz: Ośrodek Doskonalenia Nauczycieli.

$\rightarrow$ Fazlagić, J. (2018a), Cechy osób kreatywnych, bit.ly/2H0AUxp [dostęp: 14.08.2019], s. 1.

$\rightarrow$ Fazlagić, J. (2018b), Szkoła dla innowatora. Kształtowanie kompetencji proinnowacyjnych, Kalisz: Ośrodek Doskonalenia Nauczycieli.

$\rightarrow$ Ferrari, A. (2013), DIGCOMP: A Framework for Developing and Understanding Digital Competence in Europe, IRC EC.

$\rightarrow$ Ferrari, A., Cachia, R., Punie, Y. (2009), Innovation and Creativity in the EU Member States: Fostering Creative Learning and Supporting Innovative Teaching, Luxembourg: European Communities.

$\rightarrow$ Field, A. (2014), Digital tools to spark creativity, Cambrigde Assessment International Education, bit.ly/2XNoH9P [dostęp: 24.04.2019].

$\rightarrow$ Filiciak, M., Tarkowski, A. (2010), Niebezpieczne zwiq̨zki-rynkowa i społeczna produkcja kultury [w:] A. Gwóźdź (red.), Od przemysłów kultury do kreatywnej gospodarki, Warszawa: Narodowe Centrum Kultury.

$\rightarrow$ Filipowicz, G. (2016), Zarzq̨dzanie kompetencjami. Perspektywa firmowa i osobista, Warszawa: Wolters Kluwer.

$\rightarrow$ Five ways work will change in the future (2017), "The Guardian” , bit.ly/2aOXzKD [dostęp: 10.10.2017].

$\rightarrow$ Florida R., (2002), The Rise of the Creative Class: and How It's Transforming Work, Leisure, Community and Everyday Life, New York: Basic Books. 
$\rightarrow$ Frensch, P.A., Sternberg, R.J. (1989), Expertise and intelligent thinking: when is it worse to know better, "Advances in the Psychology of Human Intelligence", 5, s. 157-188.

$\rightarrow$ Fürst, G., Ghisletta, P., Lubart, T. (2016), Toward an integrative model of creativity and personality: Theoretical suggestions and preliminary empirical testing, "Journal of Creative Behavior", 50 (2), s. 87-108.

$\rightarrow$ Gelb, M.J. (2001), Myśleć jak Leonardo da Vinci. Siedem kroków do genialności na co dzień, Poznań: Dom Wydawniczy REBIS.

$\rightarrow$ Gerhart-Hauptmann-Schule (2019), AGs an der GHS, 18.09.2016, bit.ly/2LU93SN [dostęp: 4.05.2019].

$\rightarrow$ Gewerbliche Schule Tübingen (2017), Projekte des ITG, bit.ly/2NysCCA [dostęp: 4.05.2017].

$\rightarrow$ Gibb, A.A. (1993), Enterprise culture and education understanding enterprise education and its links with small business, entrepreneurship and wider educational goals, "International Small Business Journal”, 11 (3), 11-34.

$\rightarrow$ Gibb, S. (2014), Soft skills assessment: Theory development and the research agenda, "International Journal of Lifelong Education”, 33 (4), s. 455-471.

$\rightarrow$ Giddens, A. (2009), Europa w epoce globalnej, Warszawa: Państwowe Wydawnictwo Naukowe.

$\rightarrow$ Girouard, A., Treacy Solovey, E. i in. (2010), From Brain Signals to Adaptive Interfaces: using FNIRS in $\mathrm{HCl}$. Brain Computer Interfacts: Human-Computer Interaction Series, 3, s. 221-237.

$\rightarrow$ Góralski, A. (1996), Reguły treningu twórczości, Warszawa: Wydawnictwo Naukowe Scholar.

$\rightarrow$ Green, C.S., Bavelier, D. (2008), Exercising your brain: a review of human brain plasticity and training-induced learning, „Psychology and Aging", 23 (4), s. 692.

$\rightarrow$ Greenberg, S., Buxton, B. (2008), Usability evaluation considered harmful (some of the time) [w:] R. Grinter, T. Rodden, P. Aoki, E. Cutrell, R. Jeffries, G. Olson, Proceedings of the SIGCHI Conference on Human Factors in Computing Systems, New York: ACM, s. 111-120.

$\rightarrow$ Griffiths, M. (2014), Encouraging imagination and creativity in the teaching profession, „European Educational Research Journal”, 13 (1).

$\rightarrow$ Guilford, J.P. (1967), Creativity: Yesterday, today and tomorrow, "The Journal of Creative Behavior", 1 (1), s. 3-14.

$\rightarrow$ Guilland A. i in. (red.) (2017), Sense Of Initiative And Social Skills, Laurea: Laurea University of Applied Sciences.

$\rightarrow$ Halicka, M., Halicki, J., Kramkowska, E. (red.) (2016), Starość poznać, przeżyć, zrozumieć, Białystok: Wydawnictwo Uniwersytetu w Białymstoku. 
$\rightarrow$ Haupt- und Realschule Eschershausen im Wilhelm Raabe Schulzentrum (2017b), Berufsorientierung wird an der HRS Eschershausen „GROSS" geschrieben!, bit.ly/32dHTfw [dostęp: 4.05.2017].

$\rightarrow$ Heathwron, T.E. i in. (2007), A social brain sciences approach to understanding self [w:] C. Sedikides, S.J. Spencer (red.), The Self, Psychology Press, New York, s. 3-20.

$\rightarrow$ Helman, J., Rosienkiewicz, M. (2016), Design Thinking jako koncepcja pobudzania innowacji, bit.ly/2FOttIZ [dostęp: 14.04.2019].

$\rightarrow$ Henry, C., Hill, F., Leitch, C. (2005), Entrepreneurship education and training: can entrepreneurship be taught? Part I, „Education + Training”, 47 (2), s. 98-111.

$\rightarrow$ Higgins, E.T. (1987), Self-discrepancy. A theory relating self and affect, „Psychological Review", 94, s. 319-340.

$\rightarrow$ Higgins, E.T. (1996), The Self-digest: Self-knowledge serving self-regulatory functions, „Journal of Personality and Social Psychology", 71, s. 1062-1083.

$\rightarrow$ Hilal, R. (2012), Vocational Education and Training for women and youth in Palestine: Poverty reduction and gender equality under occupation, „International Journal of Educational Development", 32 (5), s. 686-695, www.sciencedirect. com [dostęp: 1.05.2019].

$\rightarrow$ Hochanadel, A., Finamore, D. (2015), Fixed and growth mindset in education and how grit helps students persist in the face of adversity , "Journal of International Education Research", 11 (1), s. 47-50.

$\rightarrow$ Hojat, E. (2004), Creative Education: a New Experience, Teheran: Honar-Ha-Ye-Ziba, 18, s. 25-36.

$\rightarrow$ Holroyd, A., Dahlke, S., Fehr, C., Jung, P., Hunter, A. (2009), Attitudes toward aging: implications in industrial work performance , "European Journal of Work and Organizational Psychology", 18 (3), s. 347-377.

$\rightarrow$ Hołdys, A. (2019), Jak schłodzić ziemię, "Gazeta Wyborcza", 28 maja, s. 16.

$\rightarrow$ Howkins, J. (2001), The Creative Economy: How People Make Money From Ideas, London: Penguin, cyt. za: Przemysły kultury i kreatywne w latach 2014-2016 (2018), Warszawa-Kraków: Główny Urząd Statystyczny.

$\rightarrow$ Howkins, J. (2014), The Creative Economy. How People Get Money from Ideas, London: Penguin.

$\rightarrow$ IBM (2010), Global CEO Study.

$\rightarrow$ Inayat, I., ulAmin, R., Inayat, Z., SalwahSalim S. (2013), Effects of Collaborative Web Based Vocational Education and Training (VET) on Learning Outcomes, "Computers \& Education", 68, s. 153-166, www.sciencedirect.com [dostęp: 1.05.2019]. 
$\rightarrow$ Jemielniak, D. (2018), Nie z hukiem, ale ze skomleniem, „Magazyn Turning Points. Global Agenda 2019. Wydarzenia, które odmieniły twoje życie”, "Gazeta Wyborcza", 29-30 grudnia, s. 32-33.

$\rightarrow$ Jenaplan-Schule Jena (2019), www.jenaplan-schule-jena.de [dostęp: 10.05.2019].

$\rightarrow$ Jędrzejczyk, W. (2017), Definiowanie kreatywności jako kompetencji przekrojowej, „Przegląd Organizacji”, 12, s. 14-19.

$\rightarrow$ Judhi, N., Pa'wan, F., Othman, N.A., Moksin, H. (2010), Factors influencing internal and external employability of employees, „Business Economics Journal”, vol. 2010, BEj-11, bit.ly/2 LcmKgs [dostęp: 24.03.2019].

$\rightarrow$ Jung, B. (2009), Kryzys czasu, czas kreatywności i współpracy [w:] J. Osiński, S. Sztaba (red.), Nauki społeczne wobec kryzysu na rynkach finansowych, Warszawa: Oficyna Wydawnicza Szkoły Głównej Handlowej.

$\rightarrow$ Kabukcu, E. (2015), Creativity process in innovation oriented entrepreneurship: the case of Vakko, "Procedia - Social and Behavioral Sciences”, 195, s. 1321-1329.

$\rightarrow$ Kalbarczyk, A. (2015), Globalny apel o zmianę w edukacji „Dyrektor Szkoły", 1.

$\rightarrow$ Karwowski, M. (2010), Kreatywność - feeria rozumień, uwikłań, powodów. Teoretyczno-empiryczna prolegomena [w]: M. Karwowski, A. Gajda (red.), Kreatywność (nie tylko) w klasie szkolnej, Warszawa: Wydawnictwo APS, s. 12-44.

$\rightarrow$ Karwowski, M., Gralewski, J. (2013), Threshold Hypothesis: Fact or Artifact?, "Thinking Skills and Creativity", 8, s. 25-33.

$\rightarrow$ Kasza J., (2014), Wieczna radość czy przymus kreatywności-próba spojrzenia na retorykę kreatywności z punktu widzenia kulturowej ekonomii politycznej [w:] A. Zorska, M. Molęda-Zdziech, B. Jung (red.), Kreatywność i innowacyjność w gospodarce cyfrowej. Twórcza destrukcja 2, Warszawa: Oficyna Wydawnicza Szkoły Głównej Handlowej.

$\rightarrow$ Kaufman, J.C., Plucker, J.A., Baer, J. (2008), Essentials of Creativity Assessment, Hoboken, NJ: Wiley \& Sons.

$\rightarrow$ Ketchagias, K. (red.) (2011), Teaching and Assessing Soft Skills. Based on the MASS, Measuring and Assessing Soft Skills-Project, Thessaloniki: $1^{\text {st }}$ Second Chance School of Thessaloniki.

$\rightarrow$ Kim, K.H. (2005), Can only intelligent people be creative? A meta-analysis, "The Journal of Secondary Gifted Education", 16, s. 57-66.

$\rightarrow$ Kirkpatrick, D.L. (2006), Evaluating Training Programs. The Four Levels, San Francisco, CA: Berret-Koehler.

$\rightarrow$ Klimczuk, A. (2013), Kreatywne starzenie się. Przykłady zagranicznych i polskich zaleceń i praktyk [w:] A. Zawada, Ł. Tomczyk (red.), Seniorzy w środowi- 
sku lokalnym (badania empiryczne i przykłady dobrych praktyk), Katowice: Wydawnictwo Uniwersytetu Śląskiego, s. 24-46.

$\rightarrow$ Klimowicz, A. (2013), Strefy kontaktów i dysonansów w szkole, „Meritum. Mazowiecki Kwartalnik Edukacyjny", Przestrzenie szkoły, 1 (28), s. 28-34.

$\rightarrow$ Kolb, D. (1984), Experiential Learning: Experience as the Source of Learning and Development, Englewood Cliffs: Prentice-Hall, Inc.

$\rightarrow$ Kompetencje przyszłości-czwarta rewolucja przemysłowa w Europie Wschodniej, $4^{\text {th }}$ Industrial Revolution in Central and Eastern Europe Innovation and Advantage drive success, Addeco Group, 2018, www.adecco.gr/en/the-skills-report/ [data dostępu: 24.04.2019].

$\rightarrow$ Konferencja Ministerstw Szkolnictwa (2019), Who do you think you are?, bit.ly/2jAJrt4 [dostęp: 11.05.2019].

$\rightarrow$ Koudahl, P.D. (2010), Vocational education and training: dual education and economic crises, „Procedia Social and Behavioral Sciences”, 9, s. 1900-1905, www.sciencedirect.com [dostęp: 1.05.2019].

$\rightarrow$ Kozielecki, J. (1992), Twórczość i rozwiq̨zywanie problemów [w:] M. Materska, T. Tyszka (red.), Psychologia i poznanie, Warszawa: Państwowe Wydawnictwo Naukowe.

$\rightarrow$ Kożusznik, B. (2010a), Kluczowa rola psychologii we wspieraniu i stymulowaniu innowacyjności, „Chowanna", 2 (35).

$\rightarrow$ Kożusznik, B. (red.) (2010b), Psychologiczne uwarunkowania innowacyjności, Katowice: Wydawnictwo Uniwersytetu Śląskiego.

$\rightarrow$ Krasowicz, G., Kurzyp-Wojnarowska, A. (1990), Kwestionariusz do badania poczucia kontroli, textbook, Warszawa: PTP, Wydział Psychologii Uniwersytetu Warszawskiego, Laboratorium Technik Diagnostycznych im. Bohdana Zawadzkiego.

$\rightarrow$ Król, H. (2006), Transformacja pracy i funkcji personalnej [w:] H. Król, A. Ludwiczyński (red.), Zarzq̨dzanie zasobami ludzkimi. Tworzenie kapitału ludzkiego organizacji, Warszawa: Państwowe Wydawnictwo Naukowe.

$\rightarrow$ Kształcenie Ustawiczne Nauczycieli w Badenii-Wirtembergii (2019), Firma Steiff in China, bit.ly/2JfxDvK [dostęp: 4.05.2019].

$\rightarrow$ Kührt, P. (2011), Planspiel Kommunalpolitik. 29.07.2011, bit.ly/2JejbUs [dostęp: 4.05.2017].

$\rightarrow$ Kwieciński, L., Młodzińska-Granek, A. (2014), Academic entrepreneurship in the humanities and social sciences: research conducted among students of Wroclaw University, "Horyzonty Wychowania”, 13 (26), s. 33-49. 
$\rightarrow$ Laukkanen, T., Pasanen, M. (2008), Mobile banking innovators and early adopters: how they differ from other online users?, "Journal of Financial Services Marketing", 13 (2), s. 86-94.

$\rightarrow$ Learning and Skills for the Digital Era, bit.ly/2HCxHnb [dostęp: 20.04.2019].

$\rightarrow$ Leathers, D.G. (2007), Komunikacja niewerbalna, Warszawa: Państwowe Wydawnictwo Naukowe.

$\rightarrow$ Leszczyńska-Reichelt, A. (2007), Człowiek starszy i jego wspomaganie - w stronę pedagogiki starości, Olsztyn: Wydawnictwo Uniwersytetu Warmińsko-Mazurskiego.

$\rightarrow$ Lewicki, A. (1969), Niektóre problemy teorii zachowania [w:] A. Lewicki (red.), Psychologia kliniczna, Warszawa: Państwowe Wydawnictwo Naukowe.

$\rightarrow \quad$ Lubart, T.I., Sternberg, R.J. (1995), An investment approach to creativity: theory and data [w:] T.B. Ward, S.M. Smith, R.A. Finke, The Creative Cognition Approach, Cambridge, MA: The MIT Press, s. 269-302.

$\rightarrow$ Luecke, R., Katz, R. (2003), Managing Creativity and Innovation, Boston, MA: Harvard Business School Press.

$\rightarrow \quad$ Łuczak-Trąpczyńska, M., Trąpczyński, P. (2017), Fostering a multi-level approach to entrepreneurial pedagogy: the German experience , "Horyzonty Wychowania", 16 (37), s. 129-146.

$\rightarrow$ Malhi, R.S. (2010), The Hard Truth about Graduate Employability and Soft Skills, bit.ly/2TzGzj6 [dostęp: 11.04.2019].

$\rightarrow$ Markov, S. (2017), Frank Barron - Pioneer in the Psychology of Creativity , "Genvive. The Universe of Creative People", bit.ly/2JJGEgL [dostęp: 23.07.2019].

$\rightarrow$ Marody, M., Giza-Poleszczuk, A. (2004), Przemiany więzi społecznych. Zarys teorii zmiany społecznej, Warszawa: Scholar.

$\rightarrow$ Marody, M., Lewicki, M. (2010), Przemiany ideologii pracy [w:] J. Kochanowicz, M. Marody (red.), Kultura i gospodarka, Warszawa: Scholar.

$\rightarrow$ Marques, L.A., Albuquerque, C. (2012), Entrepreneurship education and the development of Young people life competencies and skills, "ACRN Journal of Entrepreneurship Perspectives", 1 (2), s. 55-68.

$\rightarrow$ Martin, J.P. (2010), Lernen durch Lehren: ein modernes Unterrichtskonzept, bit.ly/2Nzj22m [dostęp: 4.05.2017].

$\rightarrow$ Mascherini, M., Salvatore, L., Meierkord, A., Jungblut, J.M. (2017), NEETs. Young people not in employment, education or training: Characteristics, costs and polity responses in Europe, bit.ly/2JKtZbY [dostęp: 2.09.2017].

$\rightarrow$ Mathisen, G.E., Bronnick, K.S. (2009), Creative self-efficacy: an intervention study, „International Journal of Educational Research”, 48 (1), s. 21-29. 
$\rightarrow$ McCrae, R.R., Arneberg, D., Costa, P.T. (1987), Declines in divergent thinking with age: cross-sectional longitudinal, and cross-sequential analyses, „Psychology and Aging", 2, s. 130-137.

$\rightarrow$ McDonald, C., Chenoweth, L. (2009), Leadership: A crucial ingredient in unstable times, "Social Work \& Society", 7, bit.ly/30Wt7IC [dostęp: 20.04.2019].

$\rightarrow$ Mcdonalds, A. (1993), Practical methods for the apprehension and sustained containment of supernatural entities [w:] G.L. Yeager (red.), Paranormal and occult studies: Case studies in application, London: OtherWorld Books, s. 42-64.

$\rightarrow$ McKinsey and Company (2017), Technology, Jobs and The Future of Work, skrót raportu przygotowanego na Fortune Vatican Forum, grudzień 2016, aktualizacja luty 2017.

$\rightarrow$ Medina, J. (2009), 12 sposobów na supermózg. Jak przetrwać i dobrze sobie radzić w pracy, domu, szkole, Warszawa: Prószyński Media.

$\rightarrow$ Meinel, M., Wagner, T.F., Baccarella, C.V., Voigt, K.I. (2018), Exploring the effects of creativity training on creative performance and creative self-efficacy: evidence from a longitudinal study, "The Journal of Creative Behavior".

$\rightarrow$ Meintjes, H., Grosser, M. (2010), Creative Thinking in Prospective Teachers: the Status Quo and the Impact, "South African Journal of Education”, 30 (3).

$\rightarrow$ Methodenpool Uni-Koeln (2019a), Kurze Beschreibung der Methode, bit.ly/30a1IYD [dostęp: 4.05.2019].

$\rightarrow$ Methodenpool Uni-Koeln (2019b), Kurze Beschreibung der Methode, bit.ly/2QnnNZ9 [dostęp: 4.05.2019].

$\rightarrow$ Meyers, E.M., Erickson, I., Small, R.V. (2001), Digital literacy and informal learning environments: an introduction, "Learning, Media and Technology", 38 (4), s. 355-367.

$\rightarrow$ Miaźnica, Ł. (2013), Kultura - Kreatywność - Innowacyjność [w:] J. Hausner, A. Karwińska, J. Purchla (red.), Kultura a rozwój, Warszawa, s. 405-406, bit. ly/2XHuPQR [dostęp: 16.07.2019].

$\rightarrow$ Ministerstwo Szkolnictwa i Kształcenia Kraju Związkowego Nadrenia-Westfalia (2019), Das Europa Spiel: „Europa kinderleicht”, bit.ly/2XjPmpl [dostęp: 11.05.2019].

$\rightarrow$ Moczydłowska, I. (2013), Zestawienie bibliograficzne w wyborze na temat: przestrzeń szkoły, "Meritum. Mazowiecki Kwartalnik Edukacyjny”, Przestrzenie szkoły, 1 (28), s. 69-73.

$\rightarrow$ Moreno, J.J.J., Wach, K. (2014), The entrepreneurial profile of students participating in the academic entrepreneurship source: pilot study results, "Horyzonty Wychowania", 13 (26), s. 121-143. 
$\rightarrow$ Müller, F. (2006), Selbstständigkeit fördern und fordern. Handlungsorientierte und praxiserprobte Methoden für alle Schularten und Schulstufen, WeinheimBasel: Beltz.

$\rightarrow$ Mumford M.D. (red.) (2011), Handbook of Organizational Creativity, Cambridge, MA: Academic Press, s. 300-320.

$\rightarrow$ Nęcka, E. (1987), Proces twórczy i jego ograniczenia, Kraków: Wydawnictwo Uniwersytetu Jagiellońskiego.

$\rightarrow$ Nęcka, E. (1994), TRoP. Twórcze rozwiq̨zywanie problemów, Kraków: Oficyna Wydawnicza "Impuls".

$\rightarrow$ Nęcka, E. (1999), Twórcze rozwiq̨zywanie problemów, Kraków: Oficyna Wydawnicza "Impuls".

$\rightarrow$ Nęcka, E. (2001), Psychologia twórczości, Gdańsk: Gdańskie Wydawnictwo Psychologiczne, s. 23.

$\rightarrow$ Nęcka, E. (2003), Psychologia twórczości, Gdańsk: Gdańskie Wydawnictwo Psychologiczne.

$\rightarrow$ Nęcka, E. (2012), Psychologia twórczości, Gdańsk: Gdańskie Wydawnictwo Psychologiczne.

$\rightarrow$ Nęcka, E., Orzechowski, J., Słabosz, A., Szymura, B. (2012), Trening twórczości, Gdańsk: Gdańskie Wydawnictwo Psychologiczne.

$\rightarrow$ Nęcka, E., Orzechowski, J., Szymura, B. (2017), Psychologia poznawcza, Warszawa: Państwowe Wydawnictwo Naukowe.

$\rightarrow$ O'Rourke, E., Haimovitz, K., Ballweber, C., Dweck, C., Popović, Z. (2014), Brain points: a growth mindset incentive structure boosts persistence in an educational game [w:] R. Grinter, T. Rodden, P. Aoki, E. Cutrell, R. Jeffries, G. Olson, Proceedings of the SIGCHI Conference on Human Factors in Computing Systems, New York: ACM, s. 3339-3348.

$\rightarrow$ Oblicza epok. Język polski. Podręcznik. Liceum i technikum (2019), D. Chemperek, A. Kalbarczyk, D. Trześniowski (red.), Warszawa: Wydawnictwa Szkolne i Pedagogiczne, cz. 1.1.

$\rightarrow$ Obuchowski, K. (2000), Galaktyka potrzeb, Poznań: Zysk i S-ka.

$\rightarrow$ OECD (2013), OECD Review on Evaluation and Assessment Frameworks for Improving School Outcomes, Paris: Organization for Economic Co-operation and Development.

$\rightarrow$ OECD (2016), Enabling the Next Production Revolution: the Future of Manufacturing and Services - Interim Report, Meeting of the OECD Council at Ministerial Level, Paris, 1-2 czerwca 2016.

$\rightarrow$ OECD (2016), Pisa 2015 Results in Focus, bit.ly/2 haYb Nw [dostęp: 3.05.2017]. 
$\rightarrow$ OECD (2018), The Future of Education and Skills Education 2030, Paris: Organization for Economic Co-operation and Development.

$\rightarrow$ Oleksyn, T. (2006), Zarzq̨dzanie kompetencjami: teoria i praktyka, Kraków: Oficyna Ekonomiczna.

$\rightarrow$ Oleś, P., Drat-Ruszczak, K. (2008), Osobowość [w:] J. Strelau, D. Doliński (red.), Psychologia akademicka, t. 1, Gdańsk: Gdańskie Wydawnictwo Psychologiczne.

$\rightarrow$ Orbitowska, P. (2018), EduScrum - od edukacji przemysłowej do edukacji Agile, Warszawa: b.n.w.

$\rightarrow$ Osterwalder A., Pigneur Y. (2012 ), Tworzenie modeli biznesowych, Gliwice: Helion, s. 20-34.

$\rightarrow$ Othman, N., Nasrudin, N. (2016), Entrepreneurship education programs in Malaysian polytechnics, „Education + Training”, 58 (7/8), s. 882-898.

$\rightarrow$ Oude, A., Beverborg, G., Sleegers, P.I.C., Veen, K. (2015), Fostering teacher learning in VET colleges: Do leadership and teamwork matter?, "Teaching and Teacher Education", 48, s. 22-33, www.sciencedirect.com [dostęp: 12.04.2019].

$\rightarrow$ Packer, M.J., Goicoechea, J. (2000), Sociocultural and constructivist theories of learning: Ontology not just epistemology, "Educational Psychologist", 35 (4), s. 227-242.

$\rightarrow$ Parczewska, T., Zwierzchowska, I. (2017), Swoistość postrzegania kreatywności [w]: J. Bałachowicz, I. Adamek (red.), Kreatywność jako wymiar profesjonalizacji przyszłych nauczycieli wczesnej edukacji, Warszawa: Wydawnictwo Akademii Pedagogiki Specjalnej.

$\rightarrow$ Passey, D., Tatnall A., (2014), Key Competencies in ICT and Informatics. Implications and Issues for Educational Professionals and Management, IFIP Advances in Information and Communication Technology, AICT-444, Potsdam: Springer, s. $165-177$.

$\rightarrow$ Payne, J. (2000), The unbearable lightness of skill: the changing meaning of skill in UK policy discourses and some implications for education and training, "Journal of Education Policy", 15 (3), s. 353-369.

$\rightarrow$ Pellegrino, J.W., Chudowsky, N., Glaser, R. (2011), Knowing what students know: The science and design of educational assessment, Washington, DC: The $\mathrm{Na}-$ tional Academies Press.

$\rightarrow$ Perkins, D.N. (2001), The Eureka Effect: The Art and Logic of Breakthrough Thinking, New York: WW Norton \& Company.

$\rightarrow$ Phillips, D.C., Soltis, J.F. (2003), Podstawy wiedzy o nauczaniu, Gdańsk: Gdańskie Wydawnictwo Psychologiczne.

$\rightarrow$ Philpot, D. (2010), Soft Skills: More important than you might think!, 2.04.2012, bit.ly/2K0yv6A [dostęp: 16.04.2019]. 
$\rightarrow$ Piątek, Z. (2017), Czym jest Przemysł 4.0? - część 1, bit.ly/30vmvk4 [dostęp: 20.01.2018].

$\rightarrow$ Pineda-Herrero, P., Quesada-Pallares, C., Mas, O., Espona, B., Garcia, N. (2012), VET efficacy: evaluation of factors in the workplace training, „Procedia - Social and Behavioral Sciences", 46, s. 1390-1394, www.sciencedirect.com [dostęp: 12.04.2019].

$\rightarrow$ Plebańska, M., Trojańska, K. (2018), STEAM-owe Lekcje, Warszawa: e-Litera.

$\rightarrow$ Płaziak, M., Rachwał, T. (2014), Kształcenie w zakresie przedsiębiorczości na polskich uniwersytetach na studiach nieekonomicznych (na przykładzie kierunku geografia), „Horyzonty Wychowania”, 13 (26), s. 249-266.

$\rightarrow$ Polak, M. (red.) (2016), Przestrzeń fizyczna i architektoniczna. Przestrzenie edukacji 21. Otwieramy szkołę!, t. 1, Warszawa: Eduspaces21, bit.ly/2M1Z5yy [dostęp: 16.07.2019].

$\rightarrow$ Polanyi, M. (2009), The Tacit Dimension, Chicago: University of Chicago Press.

$\rightarrow$ Popescu, M.E., Roman, M. (2018), Vocational training and employability: evaluation evidence from Romania, „Evaluation and Program Planning”, 67, s. 38-46, www.sciencedirect.com [dostęp: 15.04.2019].

$\rightarrow$ Powell, L. (2012), Reimagining the purpose of VET - Expanding the capability to aspire in South African Further Education and Training students, "International Journal of Educational Development", 32 (5), www.sciencedirect.com [dostęp: 1.05.2018].

$\rightarrow$ Preckel, F., Holling, H., Wiese, M. (2006), Relationship of intelligence and creativity in gifted and non-gifted students: an investigation of threshold theory, "Personality and Individual Differences", 40, s. 159-170.

$\rightarrow$ Prensky, M. (2001), Digital natives, digital immigrants, „On the Horizon”, 9 (5), s. 1-6.

$\rightarrow$ Przemysły kultury i kreatywne w latach 2014-2016 (2018), Warszawa-Kraków: Główny Urząd Statystyczny.

$\rightarrow$ Rachwał, T., Wach, K. (2016), Badanie intencji przedsiębiorczych młodego pokolenia: wyniki ankietyzacji wśród studentów kierunków nieekonomicznych, „Przedsiębiorczość - Edukacja”, 12.

$\rightarrow$ Redding, S., Twyman, J., Murphy, M. (2013), What is an innovation in learning?, bit.ly/2XFoGEU [dostęp: 12.04.2019].

$\rightarrow$ Reiter-Palmon, R., Robinson, E.J. (2009), Problem identification and construction: What do we know, what is the future?, „Psychology of Aesthetics, Creativity, and the Arts", 3 (1), s. 43.

$\rightarrow$ Rhodes, M. (1961), An analysis of creativity, "Phi Delta Kappan”, 42, s. 305-311. 
$\rightarrow$ Richardson, C., Henriksen, D., Mishra, P., The Deep-Play Research Group (2017), The courage to be creative. An interview with Dr. Yong Zhao, "TechTrends".

$\rightarrow$ Riley, N.R, Ahlberg, M. (2004), Investigating the use of ICT-based concept mapping techniques on creativity in literacy tasks, „Journal of Computer Assisted Learning", 20 (4), s. 244-256.

$\rightarrow$ Robinson, K. (1982), The Arts in Schools: Principles, Practice and Provision, Lisbon: Calouste Gulbenkian Foundation.

$\rightarrow$ Robinson, K. (1999), All Our Futures: Creativity, Culture and Education, London: Department for Education and Employment.

$\rightarrow$ Robinson, K., Aronika, L. (2009), The Element: How Finding Your Passion Changes Everything, London: Penguin.

$\rightarrow$ Robinson, K. (2010), Oblicza Umysłu. Ucząc się kreatywności, Kraków: Wydawnictwo Element.

$\rightarrow$ Robinson, K., Aronica, L. (2016), Creative Schools, New York: Penguin.

$\rightarrow$ Rogers, E.M. (1962), Diffusion of Innovations, Glencoe, IL: Free Press of Glencoe, Macmillan Company.

$\rightarrow$ Ron, P. (2007), Elderly people's attitudes and perceptions of aging and old age: The role of cognitive dissonance? , "International Journal of Geriatric Psychiatry", 22, s. 656-662.

$\rightarrow$ Rostkowski, T., Szczęsna, A. (2004), Zarządzanie kompetencjami [w:] T. Rostkowski (red.), Nowoczesne metody zarzq̨dzania zasobami ludzkimi, Warszawa: Difin.

$\rightarrow$ Ruah, P. (2017), Betriebspraktikum im Ausland (Jahrgangsstufe Q1), bit.ly/2LDsvDi [dostęp: 4.05.2017].

$\rightarrow$ Runco, M.A. (red.) (1994), Problem Finding, Problem Solving, and Creativity, Westport: Greenwood Publishing Group.

$\rightarrow$ Rychen, D.S., Salganik, L.H. (red.) (2001), Defining and Selecting Key Competences, Gottingen: Hogrefe \& Huber Publishers.

$\rightarrow$ Sasser-Coen, J.R. (1993), Qualitative changes in creativity in the second half of life: A life-span developmental perspective, "Journal of Creative Behavior", 27, s. 18-27.

$\rightarrow$ Sawin, S. (16.05.2018), Współpraca startupów z korporacjami, „Startuj ze Startupem”, dodatek do „Rzeczpospolitej”, s. 37.

$\rightarrow$ Sawyer, K. (2006), Optimising Learning: Implications of Learning Sciences Research, OECD/CERI International Conference "Learning in the $21^{\text {st }}$ Century: Research, Innovation and Policy", Centre for Education Research and Innovation OECD/CERI. 
$\rightarrow$ Schön, D.A. (1987), Educating the Reflective Practitioner, San Francisco, CA: Jossey-Bass.

$\rightarrow$ Schulz, R. (1990), Twórczość. Społeczne aspekty zjawiska, Warszawa: Państwowe Wydawnictwo Naukowe.

$\rightarrow$ Segers, M., Dochy, F., Cascallar, E., (2003), Optimising New Modes of Assessment: In Search of Qualities and Standards, Dordrecht: Kluwer Academic Publishers.

$\rightarrow$ Seiler, K. (2019), Słyszycie mnie? Twarze: Greta Thunberg, "Wysokie Obcasy”, 22 (1036), s. 8-12.

$\rightarrow$ Sek-yum Ngai, S., Cheung, Ch., Yuan, R. (2016), Effects of vocational training on unemployed youths' work motivation and work engagement: mediating roles of training adequacy and self-actualization, "Children and Youth Services Review", 63, s. 93-100, www.sciencedirect.com [dostęp: 1.05.2018].

$\rightarrow$ Sheril, R.D. (1956), The terrifying future: contemplating color television, San Diego, CA: Halstead.

$\rightarrow$ Sienkiewicz, Ł. (red.) (2013), Polityka zarządzania kompetencjami pracowników, Warszawa: Instytut Badań Edukacyjnych.

$\rightarrow$ Silvia, P.J. (2008), Another look at creativity and intelligence: Exploring higher-order models and probable confounds, "Personality and Individual Differences”, 44, s. 1012-1021.

$\rightarrow$ Simonton, D.K. (1990), Creativity and wisdom in aging [w:] J.W. Birren, K.W. Schaie (red.), Handbook of Psychology of Aging, San Diego: Academic Press.

$\rightarrow$ Simonton, D.K. (1996), Creative expertise: A life-span Developmental Perspective. The road to Excellence: The Acquisition of Expert Performance in the Arts and Sciences, Sports, and Games, Washington, DC: American Psychological Association, s. 227-253.

$\rightarrow$ Simonton, D.K. (2010), Creative thought as blind-variation and selective-retention: combinatorial models of exceptional creativity , "Physics of Life Reviews”, 7 (2), s. 156-179.

$\rightarrow$ Soccess Handbook - Assessment of Transversal Competences. Focus On Entrepreneurship (2017) [w:] A. Guilland i in. (red.), Sense Of Initiative And Social Skills, Laurea: Laurea University of Applied Sciences.

$\rightarrow$ Spörhase-Eichmann, U. (2004), Biologie Didaktik - Praxishandbuch für die Sekundarstufe, I i II, Berlin: Cornelsen Verlag.

$\rightarrow$ Staudinger, U.M., Lopez D.F., Baltes, P.B. (1997), The psychometric location of wisdom-related performance: Intelligence, personality and more?, „Personality and Social Psychology Bulletin", 23, s. 1200-1214. 
$\rightarrow$ Staudinger, U.M., Maciel, A.G., Smith, J., Baltes, P.B. (1998), What predicts wisdom-related performance? A first look of personality, intelligence and facilitative experiential contexts, „European Journal of Personality”, 12 (1), s. 1-17.

$\rightarrow$ Stein, M.I. (1953), Creativity and culture, "The Journal of Psychology", 36 (2), s. 311-322.

$\rightarrow$ Sternberg, R.J. (1985), Beyond IQ: A Triarchic Theory of Human Intelligence, Cambridge: CUP Archive.

$\rightarrow$ Sternberg, R.J. (1999), The theory of successful intelligence , "Review of General Psychology", 3 (4), s. 292-316.

$\rightarrow$ Sternberg, R.J. (2006), The nature of creativity, "Creativity Research Journal", 18 (1), s. 87-98.

$\rightarrow$ Sternberg, R.J., Kaufman, J.C., Pretz, J.E. (2013), The Creativity Conundrum: A Propulsion Model of Kinds of Creative Contributions, London: Psychology Press.

$\rightarrow$ Steuden, S. (2012), Psychologia starzenia się i starości, Warszawa: Państwowe Wydawnictwo Naukowe.

$\rightarrow$ Strelau, J., Doliński, D. (red.) (2010), Psychologia akademicka, t. 1, Gdańsk: Gdańskie Wydawnictwo Psychologiczne.

$\rightarrow$ Szmidt, K.J. (2005), Pedagogika twórczości, Gdańsk: Gdańskie Wydawnictwo Psychologiczne.

$\rightarrow$ Szmidt, K.J. (2005), Współczesne koncepcje wychowania do kreatywności i nauczania twórczości; przeglq̨d stanowisk polskich [w:] K.J. Szmidt (red.), Dydaktyka twórczości. Koncepcje - problemy - rozwiq̨zania, Kraków: Oficyna Wydawnicza "Impuls".

$\rightarrow$ Szmidt, K.J. (2007), Pedagogika twórczości, Gdańsk: Gdańskie Wydawnictwo Psychologiczne.

$\rightarrow$ Szmidt, K.J. (2010), ABC kreatywności, Warszawa: Wydawnictwo Difin.

$\rightarrow$ Szmidt, K.J. (2013), Pedagogika twórczości, Gdańsk: Gdańskie Wydawnictwo Psychologiczne.

$\rightarrow$ Szmidt, K.J. (2013), Trening kreatywności: podręcznik dla pedagogów, psychologów i trenerów grupowych, Gliwice: Wydawnictwo Helion.

$\rightarrow$ Szmidt, K.J. (2015), Czym jest kreatywność i dlaczego dotyczy ludzi, nie rzeczy? Próba odpowiedzi na pytanie pierwsze [w]: I. Pufal-Struzik, Z. Okraj (red.), Kreatywność: pytania i odpowiedzi, Kielce: Wydawnictwo Uniwersytetu Jana Kochanowskiego, s. 15-27.

$\rightarrow$ Szwed, M., Zmienność cennej galaretki, „Poradnik psychologiczny Polityki”, Jak i po co podglądany jest mózg, 31 (3), s. 64. 
$\rightarrow$ Śmigiel, M. (2019), Mamy suszę stulecia. A będzie gorzej, „Magazyn Warszawa”, "Gazeta Wyborcza", 17 maja, s. 10, bit.ly/2z1EG4Y [dostęp: 14.08.2019].

$\rightarrow$ Tasnim, R., Yahya, S. (2013), Playing entrepreneurship: can games make a difference, „Entrepreneurial Practice Review”, 2 (4), s. 4-16.

$\rightarrow$ The European Framework (2006), European Qualifications Framework, https://ec.europa.eu/ploteus/en/content/descriptors-page, ACN 2006/962/EC [dostęp: 10.11.2018]

$\rightarrow$ The Future of Jobs. Employment, Skills and Workforce Strategy for the Fourth Industrial Revolution, World Economic Forum (2016), bit.ly/1 nf6lYI [dostęp: 25.01.2018].

$\rightarrow$ The Future of Jobs Report (2018), World Economic Forum.

$\rightarrow$ Thematic Working Group on Entrepreneurship Education (2014), Final Report of the Thematic Working Group on Entrepreneurship Education.

$\rightarrow$ Tokarz, A. (red.) (2010), Wielkie teorie osobowości: koniec czy poczq̨tek?, Lublin: Wydawnictwo Towarzystwa Naukowego KUL Jana Pawła II.

$\rightarrow$ Trzebińska, E. (2008), Psychologia pozytywna, Warszawa: Wydawnictwo Akademickie i Profesjonalne.

$\rightarrow$ Trzebiński, J. (1976), Osobowościowe warunki twórczości [w:] J. Reykowski (red.), Osobowość a prospołeczne zachowanie się ludzi, Warszawa: Państwowe Wydawnictwo Naukowe.

$\rightarrow$ Ulanowski, T. (2019), Antarktyka wymięka, "Magazyn Świąteczny”, "Gazeta Wyborcza", 23-24 lutego, s. 8-9.

$\rightarrow$ Ulatowska, R. (2013), Bariery kreatywności a zachowania twórcze - rozwój organizacji medialnych, nieopublikowana rozprawa doktorska, Kraków: Wydział Zarządzania i Komunikacji Społecznej Uniwersytetu Jagiellońskiego.

$\rightarrow$ Urbaniec, M. (2014), Współczesne wyzwania edukacji na rzecz przedsiębiorczości w szkolnictwie wyższym, „Horyzonty Wychowania”, 13 (26), s. 209-230.

$\rightarrow$ Ustawa o szkolnictwie w Berlinie (2019), SchulG Berlin - § 84 Sprecherinnen und Sprecher der Schülerinnen und Schüler, www.schulgesetz-berlin.de/berlin/ schulgesetz/teil-vi-schulverfassung/abschnitt-iv-mitwirkung-der-schuelerinnen-und-schueler-in-der-schule/sect-84-sprecherinnen-und-sprecher-der-schuelerinnen-und-schueler.php [dostęp: 4.05.2019].

$\rightarrow$ Vacek, J.J. (2011), Process oriented guided inquiry learning (POGIL), a teaching method from physical sciences, promotes deep student learning in aviation, „Collegiate Aviation Review", 29 (2), s. 78.

$\rightarrow$ Vermunt, J., Verschaffel, L. (2000), Process-oriented teaching [w:] R.J. Simons, J. von der, Linden, T. Duffy (red.), New Learning, Dordrecht: Springer, s. 209-225. 
$\rightarrow$ Wach, K. (2002), Szkoły wyższe w służbie dla rozwoju przedsiębiorczości lokalnej, „Prace Naukowe Akademii Ekonomicznej we Wrocławiu”, 951 (Zarządzanie strategiczne w teorii i praktyce), s. 263-272.

$\rightarrow$ Wach, K. (2013), Edukacja na rzecz przedsiębiorczości wobec współczesnych wyzwań cywilizacyjno-gospodarczych „Przedsiębiorczość - Edukacja”, 9, s. 246-257.

$\rightarrow$ Wach, K. (2014a), Edukacja dla przedsiębiorczości: pomiędzy przedsiębiorcza pedagogikq a edukacjq ekonomicznq i biznesowq, "Horyzonty Wychowania”, 13 (28), s. 11-31.

$\rightarrow$ Wach, K. (2014b), Europeanisation of entrepreneurship education in Europe looking back and looking forward, „Horyzonty Wychowania”, 13 (26), s. 11-32.

$\rightarrow$ Wach, K. (2015), Środowisko biznesu rodzinnego jako stymulanta intencji przedsiębiorczych młodzieży akademickiej, „Przedsiębiorczość i Zarządzanie”, XVI (7[III]), s. 25-40.

$\rightarrow$ Wach, K. (2016a), Edukacja przedsiębiorcza: analiza bibliometryczna polskiego piśmiennictwa, „Horyzonty Wychowania”, 15 (34), s. 11-26.

$\rightarrow$ Wach, K. (2016b), Edukacja w zakresie przedsiębiorczości: potencjał dydaktyczny polskich uniwersytetów, „Horyzonty Wychowania”, 15 (35), s. 11-27, DOI: 10.17399/HW.2016.153501.

$\rightarrow$ Wach, K., Wojciechowski, L. (2016), Entrepreneurial intentions of students in Poland in the view of Ajzen's theory of planned behaviour, "Entrepreneurial Business and Economics Review", 4 (1), s. 83-94.

$\rightarrow$ Wallas, G. (1926), The Art of Thought, London: Harcourt Brace.

$\rightarrow$ Wawrzyniak, J.K. (2010), Wcielenia współczesnego emeryta. Symbolika pełnionych ról [w:] D. Kałuża, P. Szukalski (red.), Jakość życia seniorów w XXI wieku. Ku aktywności, Łódź: Wydawnictwo Biblioteka.

$\rightarrow$ Wiggins, G. (1998), Educative Assessment: Designing Assessments to Inform and Improve Student Performance, San Francisco, USA: Jossey-Bass.

$\rightarrow$ Wojtanowska-Janusz, B. (2014), Wpływ muzyki i edukacji muzycznej na rozwój dzieci i młodzieży, „Zeszyty Psychologiczno-Pedagogiczne Centrum Edukacji Artystycznej", 2, s. 38-39, bit.ly/2JDXWvT [dostęp: 16.07.2019].

$\rightarrow$ Woo, K.Y. (2006), Malaysian private higher education: a need to study the different interpretations of quality, bit.ly/2Z89wo3 [dostęp: 10.04.2019].

$\rightarrow$ World Bank Group (2019), The Changing Nature Of Work, Washington, DC.

$\rightarrow$ World Economic Forum (2016), The Future of Jobs, Employment, Skills and Workforce Strategy for the Fourth Industrial Revolution, bit.ly/1 nf6IYI [dostęp: 25.01.2018]. 
$\rightarrow$ Zalecenie Rady Unii Europejskiej z dnia 22 maja 2018 r. w sprawie kompetencji kluczowych w procesie uczenia się przez całe życie (2018), Dz.Urz UE, C 189/1, bit.ly/2Ks3Lho [dostęp: 3.06.2019].

$\rightarrow$ Zhao, Y. (2012), World Class Learners: Educating Creative and Entrepreneurial Students, Thousand Oaks: Corwin.

$\rightarrow$ Zimmermann, N. (2018), Transversal or Key Competences, bit.ly/2NWhTSs [dostęp: 10.11.2018].

$\rightarrow$ Zorska, A., Molęda-Zdziech, M., Jung, B.(red.) (2014), Kreatywność i innowacyjność w gospodarce cyfrowej. Twórcza destrukcja 2, Warszawa: Oficyna Wydawnicza. 


\section{Autorzy}

Aldona Andrzejczak

Uniwersytet Ekonomiczny w Poznaniu

\section{Grażyna Bartkowiak}

Uniwersytet Morski w Gdyni

\section{Jan Fazlagić}

Unwiwersytet Ekonomiczny w Poznaniu

Adam Kalbarczyk

Międzynarodowe Liceum Paderewski

w Lublinie

Anna Klimowicz

Biuro Edukacji Narodowej IPN

Marlena Plebańska

Akademia Finansów i Biznesu Vistula

\section{Bogumila Powichrowska}

Wyższa Szkoła Ekonomiczna

w Białymstoku

\section{Dorota Roszkowska}

Elastic Cloud Solutions

\section{Sergiusz Sawin}

The Heart

\section{Agnieszka Szóstek}

UX Plus

Monika Tomczyk

Uniwersytet Szczeciński

Piotr Trąpczyński

Uniwersytet Ekonomiczny w Poznaniu 



\section{Dotychczas w Serii Naukowej ukazały się}

$\rightarrow$ Tom 1: Teacher Education Policy and Practice - International Perspectives and Inspiration

$\rightarrow$ Tom 2: Przywództwo nauczycieli

$\rightarrow$ Tom 3: Kompetencje przyszłości

$\rightarrow$ Tom 4: Przestrzenie i miejsca edukacji dorosłych w Polsce

$\rightarrow$ Tom 5: Kształtowanie kompetencji przedsiębiorczych

$\rightarrow$ Tom 6: Edukacja - relacja-zabawa

$\rightarrow$ Tom 7: Edukacja włączająca w przedszkolu i szkole

Publikacje Wydawnictwa FRSE są dostępne na stronie czytelnia.frse.org.pl

\begin{tabular}{l|l} 
ffr & Wydawnictwo \\
SRe & FRSE
\end{tabular} 
Fundacja Rozwoju Systemu Edukacji (FRSE) funkcjonuje od 1993 r. Jest jedyną w Polsce instytucją z tak dużym doświadczeniem w zarządzaniu kilkunastoma edukacyjnymi programami europejskimi. W latach 2007-2013 koordynowała w Polsce programy: „Uczenie się przez całe życie" (Erasmus, Leonardo da Vinci, Comenius i Grundtvig) oraz "Młodzież w działaniu". Pełni funkcję Narodowej Agencji Programu Erasmus+ na lata 2014-2020 oraz Narodowej Agencji Europejskiego Korpusu Solidarności. Równolegle realizuje europejskie inicjatywy informacyjno-edukacyjne: eTwinning, Eurodesk Polska, Eurydice, Europass, ECVET i EPALE. Wspiera również współpracę z krajami Wschodu, poprzez Polsko-Litewski Fundusz Wymiany Młodzieży, Polsko-Ukraińską Radę Wymiany Młodzieży oraz Centrum Współpracy SALTO z Krajami Europy Wschodniej i Kaukazu. Od 2014 roku FRSE uczestniczy we wdrażaniu Programu Operacyjnego Wiedza Edukacja Rozwój.

Fundacja jest też organizatorem wielu wydarzeń edukacyjnych, w tym konkursów promujących rezultaty projektów (EDUinspiracje i EDUinspirator, European Language Label, SElfie+). Koordynuje obchody Europejskiego Tygodnia Młodzieży oraz współorganizuje wydarzenia odbywające się w ramach Europejskiego Dnia Języków. Prowadzi działalność analityczno badawczą oraz wydawniczą (jest wydawcą m.in. kwartalników: „Języki Obce w Szkole” oraz "Europa dla Aktywnych"). 